Florida International University FIU Digital Commons

6-29-2018

\title{
La representación del Otro en el siglo XIX: la diversidad en Ricardo Palma
}

Primavera Cuder

pcude001@fiu.edu

DOI: $10.25148 /$ etd.FIDC006853

Follow this and additional works at: https://digitalcommons.fiu.edu/etd

Part of the Latin American Literature Commons, Modern Languages Commons, and the Spanish Literature Commons

\section{Recommended Citation}

Cuder, Primavera, "La representación del Otro en el siglo XIX: la diversidad en Ricardo Palma" (2018). FIU Electronic Theses and Dissertations. 3781 .

https://digitalcommons.fiu.edu/etd/3781 


\title{
FLORIDA INTERNATIONAL UNIVERSITY
}

Miami, Florida

\section{LA REPRESENTACION DEL OTRO EN EL SIGLO XIX:}

LA DIVERSIDAD EN RICARDO PALMA

(THE REPRESENTATION OF THE OTHER IN THE NINETEENTH CENTURY:

DIVERSITY IN RICARDO PALMA)

\author{
A dissertation submitted in partial fulfillment of \\ the requirements for the degree of \\ DOCTOR OF PHILOSOPHY \\ in \\ SPANISH \\ by
}

Primavera Cuder

2017 
To: Dean John F. Stack, Jr.

Steven J. Green School of International and Public Affairs

This dissertation, written by Primavera Cuder, and entitled La representación del Otro en el siglo XIX: la diversidad en Ricardo Palma (The Representation of the Other in the Nineteenth Century: Diversity in Ricardo Palma), having been approved in respect to style and intellectual content, is referred to you for judgment.

We have read this dissertation and recommend that it be approved.

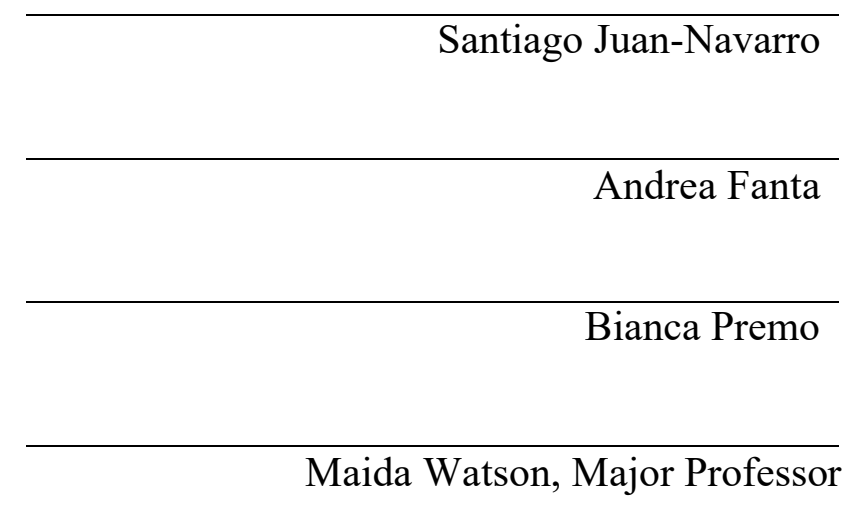

Date of Defense: June 29, 2018

The dissertation of Primavera Cuder is approved.

Dean John F. Stack, Jr. Steven J. Green School of International and Public Affairs

Andrés G. Gil

Vice President for Research and Economic Development and Dean of the University Graduate School

Florida International University, 2018 


\section{AGRADECIMIENTOS}

En primer lugar, quiero mostrar mi mayor agradecimiento a la Dra. Maida

Watson, directora de esta tesis doctoral, ya que sin su orientación y apoyo esta tesis no hubiera sido posible.

En segundo lugar, mi agradecimiento es para los miembros de mi comité, el Dr.

Santiago Juan-Navarro, la Dra. Andrea Fanta, y la Dra. Bianca Premo, por su amabilidad y apoyo en este proceso.

Finalmente, le doy las gracias a mi familia, Sergio, Sabrina, Fulvia y Aldo, cuya paciencia y cariño me ha ayudado a superar todos los obstáculos. 


\title{
ABSTRACT OF THE DISSERTATION \\ LA REPRESENTACION DEL OTRO EN EL SIGLO XIX:
}

LA DIVERSIDAD EN RICARDO PALMA

(THE REPRESENTATION OF THE OTHER IN THE NINETEENTH CENTURY:

DIVERSITY IN RICARDO PALMA)

\author{
by
}

Primavera Cuder

Florida International University, 2018

Miami, Florida

Professor Maida Watson, Major Professor

The historical distribution of power in Peru, characterized by segregation and oppression, changed drastically after its independence from Spain. Starting in the second half of the 19th century, the rigid social policies of the Colony gave way to ideas of tolerance, such as the Indigenist and Indianist movements of post-colonial Latin America. No longer considered enemies of the country, several minorities were gradually integrated in the Peruvian society, collaborating in the formation of a new national identity. This improvement was selective, however, and the new ideas of integration often involved a new and more pernicious control of the Peruvian nation. Central to this discourse is the one that the Peruvian mulatto writer Ricardo Palma presents in his Tradiciones (1864-1910), characterized by ambiguous representations of traditionally stigmatized individuals, such as Native Americans, African Americans, and women. Other groups, such as Creoles, Mestizos, or Mulattoes (like Palma), struggle to overcome 
their social boundaries in order to create a new set of identities built on idealized national models.

The prevailing tendency in much of the research written about this situation has been to focus almost exclusively on the situation of individual minorities within society, neglecting the role played by these groups in the construction of the Peruvian national identity. Moreover, it has failed to address the 19th century social and psychological struggle among minorities to be recognized within the newly formed nation. My research addresses these issues in Peruvian studies using the examples of Palma's Tradiciones, with the aim of exploring the particularities of the post-colonial new configuration of nation, identity, and power. 


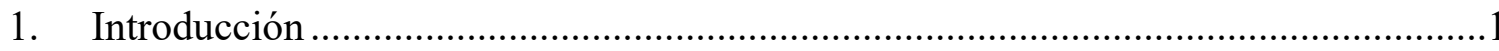

2. La teoría del Otro: ideología, identidad e historia ……............................................18 barbarie

2.1. Nexo entre pasado y presente decimonónico. Orientalismo, civilización y

2.2. Ciencia y determinismo: barbarie, bestialismo y monstruosidad .................38

3. Otros internos y externos. Identidad y nación en los discursos decimonónicos .........51

3.1. Lengua, escritura y educación......................................................................60

3.2. Extranjeros y blancos en el Perú decimonónico ...........................................73

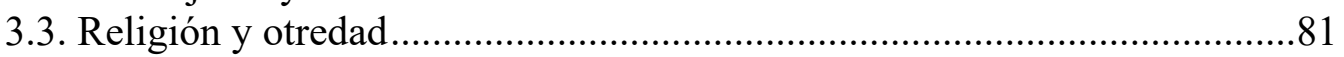

4. Mujeres, marimachos y maricones: género y sexualidad en los discursos decimonónicos 100

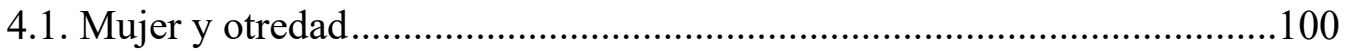

4.2. Mujeres y estética ……………………………….........................114

4.3. Mujeres y raza..................................................................................118

4.4. Marginalidad y otredad de género ……………………............................122

4.5. Marimachos y maricones: homosexualidad y Otredad de genero .............128

5. "Mestizo educado, diablo encarnado": mezclas raciales en Ricardo Palma.............139

5.1. Castas, limpieza de sangre y gracias al sacar..........................................140

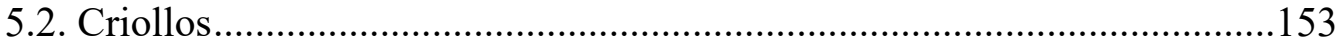

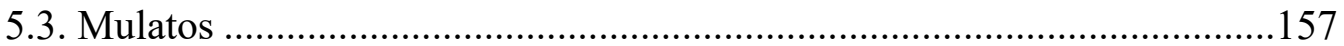

5.4. "Mestizo educado, diablo encarnado" ....................................................162

6. Cholos, piezas de ébano, y culíes: las tipificaciones raciales en los discursos decimonónicos

6.1. Extranjeros en su propia tierra: los nativos en los discursos decimonónicos

6.2. Piezas de ébano, morenos, y cimarrones: afroamericanos en el Perú........183

6.3. Migrantes asiáticos en los discursos decimonónicos: los culíes en el Perú

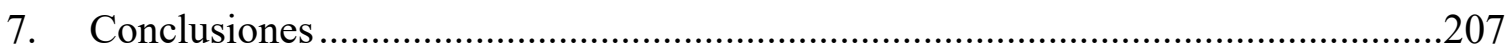

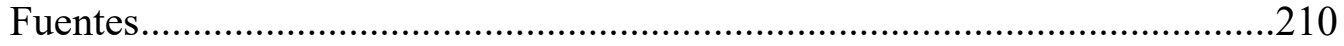

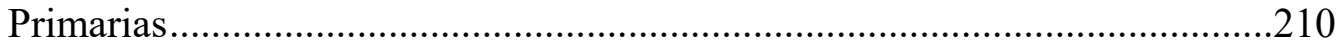

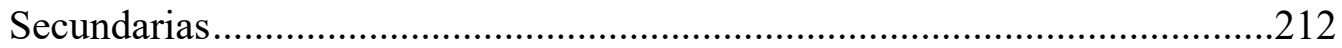

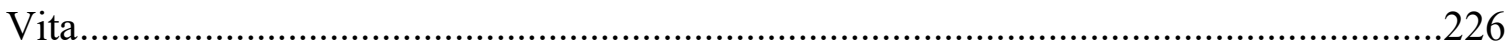




\section{Introducción}

La distribución étnica, política y de género en el Perú colonial, caracterizada por una estructura jerarquizada e inflexible, da paso a importantes cambios tras su independencia de España en el siglo XIX. Las políticas discriminatorias de la Colonia son sustituidas por ideas de tolerancia y convivencia que, más tarde en este siglo, favorecen el surgimiento de corrientes sociales y literarias como los movimientos indianistas, indigenistas y feministas del cambio de siglo. Puesto que la discriminación se considera incompatible con el nuevo orden sociopolítico, los discursos a favor de la defensa de las minorías se filtran en la formación ideológica de las élites y las clases medias criollas. Sin embargo, la asimilación de las minorías dentro de la nueva sociedad es selectiva, puesto que se favorece una regulación o normalización de la diversidad en ocasiones tan dañina como en etapas anteriores. En este periodo la sociedad peruana empieza a ser controlada por una élite patriarcal y simbólicamente blanqueada, una burguesía criolla que se convierte en representante de la nueva nación y sus narrativas.

En la construcción de estos discursos, adquiere particular importancia la obra del célebre escritor peruano Ricardo Palma (1833-1919), especialmente sus Tradiciones, unos relatos cortos de ficción histórica escritos entre 1864 y 1910 y caracterizados por una representación ambigua de individuos tradicionalmente marginados. Aunque Palma escribe en una era marcadamente patriarcal y pre-indigenista, o pre-indianista, el autor presenta de manera ambigua a los subalternos u "Otros" de su país, como es el caso de los nativos americanos (llamados indios), los afrodescendientes, y las mujeres. Asimismo, mestizos, mulatos, o los llamados pardos (como era el mismo Palma) parecen 
luchar para trascender sus limitaciones sociales y étnicas con el fin de crear una nueva serie de identidades basadas en modelos nacionales idealizados.

El propósito de esta disertación será la de (1) establecer la manera en que los individuos marginalizados (u Otros) son representados en los discursos postcoloniales latinoamericanos y las estrategias retóricas empleadas en la obra de Ricardo Palma (1833-1919). Consideraré tanto a Otros internos (o nacionales) como a Otros externos (o extranjeros). Tales grupos incluyen los individuos que han sido tradicionalmente estigmatizados debido a su nacionalidad, afiliación política, religión, etnia, o género. Con este fin, analizaré la obra de Palma, y en especial sus Tradiciones, un extenso corpus de relatos breves que combinan ficción y acontecimientos históricos. Asimismo, (2) determinaré de qué manera la presencia de Otros, tanto dentro como fuera del país, llegan a ser fuente de preocupación en la recién formada nación peruana, en la que a menudo se perciben como enemigos étnicos, económicos, políticos, morales o religiosos. Por otra parte, aunque la crítica no le considere un escritor feminista, indigenista, o indianista (tal como se percibe claramente en autores posteriores), uno de mis objetivos será el de (3) demonstrar que los discursos de Palma y sus contemporáneos sobre los Otros no siempre son negativos. Con tal propósito, compararé las representaciones de individuos marginales hechas por Palma con la de otros discursos decimonónicos que describen a mulatos, afrodescendientes, mestizos, nativos americanos, europeos, y mujeres, entre otros.

Conjuntamente, pretendo (4) examinar las ideas sobre la importancia de la presencia de Otros en la formación de las identidades (nacionales) peruanas. Me centraré principalmente en el imaginario que empieza a tomar forma después de la emancipación 
de la Corona española en 1821. Las identidades que se forman en este periodo se apoyan en la idea de que la nación incorpora una comunidad criolla cuya identidad debe ser ensalzada mediante la demarcación de su posición social, necesariamente opuesta a la de otros grupos marginales, especialmente los afrodescendientes y nativos americanos. Por último, procuraré (5) avalar la hipótesis de que la literatura peruana decimonónica contribuyó con la construcción de imágenes y estereotipos sobre los Otros, afectando su situación social en el país. Mi objetivo final es el de (6) participar en los argumentos contra los discursos de categorización determinista de ciertos gr en cuanto a su cultura, etnia, o género, entre otros. Al analizar las causas subyacentes de tales actitudes, argumentaré que este proceso está determinado por intereses políticos o económicos y no por cuestiones empíricas.

Con el fin de alcanzar estos objetivos, partiré de la hipótesis de que (1) existe una conexión entre la representación de distintos Otros, tanto internos como externos, tales como Otros políticos, religiosos, étnicos o de género. Tales grupos incorporan diferentes discursos de rechazo y marginalización. (2) Argumentaré que, en el Perú del siglo XIX, tanto afrodescendientes como nativos americanos, entre otros, son individuos simultáneamente marginales y centrales en los discursos de la comunidad criolla. Mediante su representación o exclusión de tales discursos, estos grupos adquieren una relevancia transcendental, mientras que sus voces son oídas esporádicamente.

Postularé que (3) el Perú del siglo XIX es un país incipiente en fase de formación identitaria. Por consiguiente, se halla en un estado de "maleabilidad ideológica", y es objeto de influencias nacionales e internacionales en cuanto a sus perspectivas hacia la Otredad. Asimismo (4) propondré que en el Perú decimonónico surgen discursos sobre 
"tipos" sociales influenciados por categorizaciones coloniales, como las pinturas de Castas, las leyes que regulan los roles de distintos grupos sociales, y el concepto de "limpieza de sangre" importado desde España. Estas categorizaciones ontológicas favorecen a criollos, especialmente blancos, estigmatizando otros colectivos. Argumentaré (5) que en el contexto postcolonial aflora una fluctuación entre inclusión y rechazo de los Otros, que, en ocasiones, resulta en su incorporación en un puesto más central dentro de la sociedad peruana. Sin embargo, tal incorporación tiende a cancelar y a homogeneizar las características de estos Otros. Finalmente, postularé (6) que las Tradiciones de Ricardo Palma contienen una importante fuente de información sobre la estratificación social del país, ya que describen una amplia variedad de individuos marginales y centrales en distintos momentos históricos, y expuestos a diversas actitudes sociales hacia ellos.

Con el fin de avalar tales hipótesis, me apoyaré en el marco teórico de una serie de escuelas críticas y tendencias que han influenciado los estudios literarios y culturales, especialmente a la hora de analizar los encuentros entre distintos grupos sociales. Haré especial hincapié en las herramientas de escritores y críticos feministas, cuyo interés se centra en la lucha por la igualdad de género. Destaca la labor de Elaine Showalter, Hélène Cixous, Luce Irigaray, Julia Kristeva, Alice Jardine, y Gayatri Chakravorty Spivak, y de las feministas de "tercera ola" de los años 1990, quienes defienden que no existe un único modelo de mujer, considerando aspectos como su entorno social, 
orientación sexual, nacionalidad, etnia, clase social, o religión (Selden 224). ${ }^{1}$ Asimismo, el feminismo contemporáneo abraza los intereses no sólo de la mujer, sino de todo colectivo tradicionalmente estigmatizado, compartiendo numerosas ideas con las teorías queer, puesto que ambas corrientes rechazan la polaridad de la sexualidad y el género, afirmando que la categorización binaria de lo masculino y lo femenino responde a una serie de construcciones sociales (Selden 244). Tanto las teorías queer como las feministas insisten en la "auto-designación" de la identidad propia, luchando contra etiquetas externas (244).

En línea con las teorías sobre los Otros de género, es importante señalar los trabajos de teóricos postcoloniales como Frantz Fanon, Edward Said y Homi Bhabha. Estos críticos se centran en los efectos del colonialismo y el imperialismo en etapas posteriores y analizan aspectos como la explotación y las condiciones materiales de minorías étnicas, religiosas, políticas o de clase en las excolonias (Bennett 15). ${ }^{2}$ En la obra seminal de Edward Said, Orientalism (1978), el autor analiza el concepto de "autodefinición", centrándose en el hecho de que existe una separación psicológica entre el yo y el Otro, un filtro socialmente aceptado a través del cual se interpreta la otredad (o alteridad) (Bennett 238; Tyson 420). Las comunidades privilegiadas, por lo tanto, se

\footnotetext{
${ }^{1}$ Cabe destacar la labor de (proto-)feministas anteriores como Olympe de Gouges (1748-1793), Mary Wollstonecraft (1759-1797), y Concepción Arenal (1820-1893); la de las sufragistas y otras escritoras del siglo XX como Simone de Beauvoir y Virginia Woolf. En ocasiones, también se ha hecho una lectura feminista de la obra de Sor Juana Inés de la Cruz (1651-1695).

${ }^{2}$ El concepto de "neocolonialismo", explorado, entre otros, por Jean-Paul Sartre, es otro fenómeno digno de mención en los estudios postcoloniales. Entre otras acepciones, el neocolonialismo se describe como el "[p]redominio e influencia determinantes, especialmente en el campo de la economía, por parte de antiguas potencias coloniales, naciones poderosas y empresas internacionales sobre países descolonizados o en vías de desarrollo" (Real Academia).
} 
sitúan en un lugar central, construyendo identidades que reflejan sus deseos, represiones, inversiones, y proyecciones (Said, Orientalism 28). En The Location of Culture (1994), Homi Bhabha también considera los conceptos de más allá, los intersticios, o los límites, no sólo físicos (geográficos), sino también temporales, en los que las ideologías y las identidades sociales son renegociadas (18-21). Bhabha sugiere que existen espacios dictatoriales con los que los individuos de identifican, y aquellos que se consideran pertenecientes a esferas distintas (o entre esferas) deben juzgarse como Otros.

La literatura latinoamericana del siglo XIX ofrece un importante número de obras donde aflora el tema del Otro. Podemos mencionar escritores como el español Esteban Terralla y Landa, quien, en el cambio de siglo, escribió la colección de poemas Lima por dentro y fuera (1797) después de establecerse en la capital. Asimismo, destacan los argentinos Esteban Echeverría, escritor de El matadero (1826) y La cautiva (1837), y Domingo Faustino Sarmiento, autor de Facundo o civilización y barbarie en las pampas argentinas (1845). En México sobresale José Fernández de Lizardi, con El Periquillo Sarniento (1816), y, en Cuba, Cirilo Villaverde, con Cecilia Valdés (1839), y José Martí, con su ensayo Nuestra América (1891). Finalmente, la cuestión de la otredad está presente en trabajos de autores peruanos como Felipe Pardo y Aliaga, en los artículos y ensayos costumbristas que publica en su periódico El espejo de mi tierra; Mercedes Cabello de Carbonera, en su novela Blanca Sol (1889); Clorinda Matto de Turner, en las Tradiciones cuzqueñas (1886), en sus novelas Aves sin nido (1889), Índole (1891), y Herencia (1893), y en sus Leyendas y recortes (1893); Clemente Palma, en su tesis El porvenir de las razas en el Perú (1897); Manuel González Prada, en el artículo indigenista "Nuestros indios" (1904); y el escritor español afincado en Jauja, Ladislao 
Graña (1817-1862) con la novela Sé bueno y serás feliz (1860) y su tesis titulada Factores sociales de delincuencia en el Perú (1899).

Por su parte, Manuel Ricardo Palma y Soriano (1833-1919), conocido como Ricardo Palma, fue un autor prolífico que cultivó una gran variedad de géneros y estilos, como podemos observar en sus numerosos relatos cortos, novelas, ensayos, crónicas, obras poéticas y dramáticas. El autor a menudo mostraba un talante crítico y satírico, que a menudo se inclinaba hacia la picardía y la sordidez, pero una de sus grandes pasiones era la historia, como el mismo autor admite en sus Tradiciones: "Literariamente, tengo la manía de vivir en el pasado. El ayer siempre es poético: es una especie de sol al que apenas se le ven manchas, porque está muy lejos" ("Los plañideros del siglo pasado", quinta serie n.p.). ${ }^{3}$ Entre sus obras, cabe destacar su colección de ensayos históricos recogidos en sus Anales de la inquisición de Lima (1863), donde hace una acérrima crítica de la Inquisición en la América Colonial. A la hora de escribir sus Anales, Palma analiza numerosos documentos coloniales, como los autos de fe de la Inquisición limeña, conservados en la Biblioteca de Lima antes de su saqueo de 1881, durante la Guerra del Pacífico (Anales 5-6). El libro recoge los hechos y nombra las autoridades más destacadas del "Santo Oficio limeño, desde su instalación en 1570 hasta el momento de su primera abolición, en 1813" (Hempe, "Ricardo" n.p.). Asimismo, a partir de 1897, con la publicación de la edición madrileña de los Anales, Palma añade en la obra el interesante ensayo titulado Supersticiones de los peruanos, en el que habla sobre "las

\footnotetext{
${ }^{3}$ Para citar las Tradiciones de Ricardo Palma, se utilizará la siguiente edición: Palma, Ricardo. Tradiciones. Biblioteca Virtual Universal, 2003. http://www.biblioteca.org.ar/libros/71164.pdf. Consultado 10 junio 2018. Al carecer de numeración de páginas, se indicará la serie y el nombre de la tradición citada.
} 
creencias y ritos tradicionales de la población nativa" (n.p.). Otro ensayo histórico es su Refutación a un compendio de historia del Perú (1886), escrito en contestación al texto escolar de historia del jesuita Ricardo Cappa, Historia compendiada del Perú, en el que el clérigo ataca al movimiento emancipatorio peruano (Armas 124). En esta obra, Palma acomete contra los jesuitas y encabeza una protesta y logrando que el Congreso peruano expulse del país a la orden religiosa (125). También cabe mencionar El santo de Panchita (1859), un sainete (obra teatral de carácter cómico) que Manuel Ascencio Segura escribe con Palma. En la obra afloran problemáticas cuestiones de género y estereotipos sobre la mujer, siendo una de las pocas obras del periodo que, además, menciona brevemente la situación de los chinos en el Perú decimonónico.

Como lingüista y presidente de la Academia Peruana de la Lengua (desde su fundación, el 5 de mayo de 1887), Palma aboga de manera infructuosa por la aceptación por parte de esta institución de nuevos vocablos, que recoge en sus libros Neologismos y americanismos (1896) y Papeletas lexicográficas (1903). En el cambio de siglo, el autor publica Cachivaches (1900), un libro misceláneo en el que mezcla artículos sobre literatura, cartas, reflexiones críticas y estudios históricos. Otras obras son Rodil (1851), Corona patriótica (1853), Mauro Cordato (1853), Poesías (1855), Armonías (1865), Congreso Constituyente. Semblanza de un campanero (1867), Pasionarias (1870), Verbos y gerundios (1877), La Bohemia de mi tiempo (1886), y Recuerdos de España (1897) (Pérez Garay 19). Asimismo, destaca la publicación del Epistolario de Palma y la prolífica labor periodística del autor, quien escribe en diarios y periódicos como $E l$ Diablo, El Correo de Lima, La Semana, La Ilustración, El Heraldo de Lima, El Liberal, 
La Zamacueca Política, El Diario, La Revista de Lima, La República, El Mercurio, y La Campana (Pérez Garay 19, 30).

Sin embargo, la obra maestra de Palma, por la que pasa a la posteridad, está compuesta por sus Tradiciones (1872-1910), unos 453 relatos cortos de ficción histórica escritos a lo largo de cerca de cuatro décadas (Valero, Lima 100; U. Ricardo n.p.). Enmarcados dentro de la historia peruana, especialmente en Lima, sus relatos destacan por su oralidad y se inspiran tanto en hechos históricos como en anécdotas populares de carácter liviano y satírico. La mayoría de las tradiciones, 339, hablan sobre la conquista española y la estructura del virreinato peruano entre 1532 y 1821 , mientras que un importante número de relatos se ambientan en el siglo XIX, con 43 tradiciones sobre la Emancipación del Perú y 49 sobre la República después de 1821 (Valero, Lima 100; U. Ricardo n.p.). Finalmente, seis tradiciones se centran en el contexto peruano precolombino del periodo Tawantinsuyu (1438-1533) y 16 no se ambientan en un momento histórico determinado (U. Ricardo n.p.). Después de las Tradiciones, salieron a la luz colecciones más reducidas en libros con diversos títulos divididos según sus temáticas o fechas de publicación en distintos periódicos: Ropa vieja (1889), Ropa apolillada (1891), Mis últimas tradiciones (1906), Apéndice a mis últimas tradiciones (1910), y Tradiciones en salsa verde (1973), publicada póstumamente.

Según Ruth Sievers, muchas de las leyendas sobre el pasado escritas por Palma son frutos de su imaginación y creatividad, por lo que carecen de base histórica, mas, cuando el autor "tenía noticias de una leyenda rara", siempre tomaba nota del acontecimiento para utilizarlo en una de sus Tradiciones (468). Asimismo, su pasión por la investigación y la lectura lleva al autor a estudiar innumerables documentos históricos 
en los que se inspira para sus relatos. Entre las fuentes utilizadas por Palma destacan las obras de los cronistas Inca Garcilaso de la Vega, Comentarios reales $(1609,1617)$, Fray Antonio de la Calancha, Crónica moralizada del Orden de San Agustín en el Perú (1638), y José Acosta, autor de la Historia natural y moral de las Indias (1589), que se entremezclan en un gran número de tradiciones (Sievers 464). Otra fuente de inspiración sobre los relatos ambientados en el siglo XVII fue Diente del parnaso, un corpus de poemas y relatos satíricos escrito por Juan de Caviedes entre 1683 y 1691 (Sievers 465). Asimismo, Palma utilizó el folleto anónimo Papeles varios (1776) para sus tradiciones sobre la Colonia (Sievers 464). La obra del historiador William Hickling Prescott (17961859), y el Diccionario histórico biográfico de Mendiburu también fueron fuentes importantes para el autor, quien las utilizó para corroborar la información histórica presentada en sus Tradiciones (Sievers 465, 467). Finalmente, Palma se inspira en La revolución de la independencia del Perú (1860) de Benjamín Vicuña Mackenna y El suelo de Arequipa convertido en cielo (1752) de Ventura Travada, entre otras obras (Sievers 466).

Las primeras tradiciones salen a la luz como artículos sin orden establecido en diarios o revistas; más tardes, se publican varias ediciones y colecciones en las que se reúnen diversas tradiciones organizadas y divididas en series (Palma, Cien xvii). En estos relatos cortos de ficción, Palma usualmente muestra "versiones apócrifas" del pasado, incluyendo una aclaración histórica al comienzo de cada tradición, que no siempre se ajusta a la realidad (Watson, "Arte" 45). A menudo, su finalidad es la de dar ejemplo con las costumbres peruanas, y ofrecer su opinión sobre las mismas con un fin didáctico y moralizante. Al tratarse de un relato corto de ficción, que narra de forma entretenida 
costumbres y acontecimientos históricos, la "tradición" puede considerarse un género literario independiente. Se diferencia del género del cuadro de costumbres al no tratarse de una "instantánea" que plasma la vida de los habitantes de un lugar en momento concreto, sino que se remonta a un pasado histórico con un espacio temporal más amplio. Tal como nos recuerda Merlin Compton, al mezclar su vocación de historiador con su colorida imaginación, "Palma no escribió la historia del Perú" sino que "escribió $s u$ historia del Perú", ya que, como el propio autor admitió, en su obra casi siempre "hay una mezcla de la verdad, infinitesimal que sea, con la ficción" (34, cursiva añadida). Asimismo, destaca la definición de "tradición" de José de la Riva-Agüero, quien afirma que se trata de "un género mixto o mestizo, producto del cruce de la leyenda romántica breve y el artículo de costumbres" (Porras 56). Esta definición parece confluir con la propia identidad del autor y su carácter voluble. Carlos Villanes Cairo resume el talante cambiante de la obra de Palma y enfatiza como su vida personal influye en el autor:

Palma es irreverente y anticlerical, pero el aire de los conventos le fascina; admira la pureza y el valor del aborigen, pero nunca pone en sus manos una lanza; es patriota y republicano, pero escribe del total de las 453 tradiciones 339 sobre la colonia y no es colonialista; lucha sin tregua por ser castizo, pero es el peruano que más ha trabajado por imponer palabras americanas en el Diccionario de la Academia de la Lengua. Y esta actitud cambiante le lleva a ser incomprendido y tachado de ambivalente. (Villanes 56-57) 
La obra de Palma presenta un amplio abanico de personajes de todas las etnias, géneros, religiones y clases sociales. Ocasionalmente, el autor sazona su obra con pasajes dramáticos, propios del romanticismo, mientras critica las instituciones peruanas, especialmente las políticas y religiosas. Su obra se caracteriza por el uso lenguaje popular, nutriéndose de refranes, poesías y canciones del pueblo peruano. Tales recursos le otorgan un talante oral, permitiendo que el autor incluso dialogue con sus lectores. Por otra parte, su obra no se limita a plasmar testimonios hablados y populares, sino que también hace un profundo estudio de los archivos históricos de la Biblioteca Nacional del Perú, una institución en la que Palma trabaja y dirige.

Entre otros trabajos críticos de las últimas décadas que se centran en Palma y la representación de los Otros en Latinoamérica destacan los de Oswaldo Holguín Delgado con una amplia producción crítica sobre el autor y su contexto histórico. En especial, nos interesa su capítulo "Ricardo Palma y la cultura negra" (2000), que se detiene en el estudio de la representación de los afroperuanos, y su artículo "Trazos para el perfil religioso de un liberal decimonónico (Ricardo Palma)", sobe la perspectiva del autor hacia las cuestiones religiosas. Asimismo, destaca el artículo de James Higgins, con título “Las Tradiciones peruanas de Ricardo Palma: la historia como legitimación” (2001), en el que explora cómo el autor, por un lado, reprocha la explotación de los nativos americanos y la esclavitud en la Colonia, y, por otro, diseña un modelo de nación controlado por las clases medio altas limeñas, marginando los grupos sociales que no pertenecen a ella. Álvaro Sarco, en su artículo "Irresueltos discursos del canon cultural peruano" (2005), habla sobre cuestiones como la "superioridad biológica" de una "raza" sobre otra, el determinismo cultural y de clase, y el mestizaje, subrayando el hecho de 
que el racismo se encuentra fuertemente enraizado en la sociedad peruana. Asimismo, Luz Ángela Martínez, en "La espectacularización de la Colonia y fundación de la identidad republicana en las Tradiciones Peruanas de Ricardo Palma" (2003) también estudia el tema racial, centrándose en cuestiones como la lengua y la identidad. Richard Leonardo escribe el artículo “'Los negros no saben amar’: nación, representación y exclusión en 'La emplazada' de Ricardo Palma” (2015), cuyo objetivo es el de demostrar que en esta tradición Palma examina el proyecto de nación y los discursos sobre la inclusión o exclusión de los afroperuanos en la misma. Marcel Velázquez Castro tiene una amplia producción de artículos y libros sobre la representación de la otredad en el Perú. Destacan sus libros Las máscaras de la representación: el sujeto esclavista y las rutas del racismo en el Perú (1775-1895) (2005) y La mirada de los gallinazos: cuerpo, fiesta y mercancía en el imaginario sobre Lima (1640-1895) (2013). En el primero, dedica un capítulo sobre la representación de la esclavitud en las Tradiciones de Palma, mientras que en el segundo escribe una sección sobre la otredad racial y de género en Palma y sus contemporáneos.

La cuestión racial se mezcla con el pensamiento feminista en "Poniendo a cada quien en su lugar: estereotipos raciales y sexuales en la Lima del siglo XIX" (1998) de Patricia Oliart, un interesante ensayo sobre mujeres y Otros raciales en el que estudia la obra de autores como Ricardo y Clemente Palma. Otro trabajo a considerar sobre las cuestiones de género es el de Dora Bazán Montenegro, quien escribe Mujeres, ideas y estilo en las tradiciones de Palma (2001) sobre el papel de la mujer en las Tradiciones. Merlin Compton escribe el artículo "El sentimiento del honor en las Tradiciones peruanas de Ricardo Palma" (2000), en el que reflexiona sobre cómo se aplica el 
concepto del honor peninsular en el universo creado por Palma, en especial, en lo concerniente al tema del honor y la mujer. Maida Watson escribe "Arte y literatura en el costumbrismo peruano decimonónico" (2006), explorando las descripciones decimonónicas sobre la figura de la mujer "tapada" en las Tradiciones. En el artículo argumenta que estas limeñas mantienen el atuendo colonial tras la independencia como desafío a la sociedad patriarcal y, a su vez, emancipación de la misma. Asimismo, Elisa Sampson Vera Tudela, en Ricardo Palma's Tradiciones. Illuminating Gender and Nation (2012), explora la importancia de lo marginal y anecdótico en la obra de Palma, a través de la cual analiza las identidades raciales, sexuales y políticas del Perú decimonónico. El artículo "Reading Transgression in Ricardo Palma's Tradiciones en salsa verde" (2014) de Elisabeth L. Austin, pone de manifiesto la importancia de la moralidad sexual y la heterosexualidad en la formación de una identidad nacional peruana. Sin embargo, también argumenta la oscilación entre los retratos de transgresión y crítica hacia la represión sexual de las Tradiciones frente a la auto-represión presente en la sociedad decimonónica.

Entre los autores que reflexionan sobre cuestiones de clase y lengua, destaca Flor María Rodríguez-Arenas, con su artículo "El lenguaje coloquial y el humor en las Tradiciones en salsa verde de Ricardo Palma" (2001), donde explora el uso del lenguaje en las tradiciones estudiadas y el papel de las clases marginales. Del mismo modo, hace una crítica de las instituciones religiosas y la falsa moral de la sociedad del periodo. Teodoro Hampe Martínez, en "Las Tradiciones peruanas y el imaginario de la nobleza titulada del virreinato" (2001), expone la perspectiva de Palma sobre la nobleza titulada del Virreinato, trasladando el imaginario popular colonial y su herencia al siglo XIX. 
Asimismo, argumenta que los retratos están repletos de exageraciones y verdades tergiversadas que reflejan la subjetiva perspectiva del autor. Isabelle Tauzin Castellanos, en "Refranes y tradiciones en la obra de Ricardo Palma" (2003), pone de relieve, entre otros aspectos, el talante nacionalista del autor y su reivindicación de la lengua y la escritura peruanas, un tema también analizado por Mariela de la Torre en "Las ideas lingüísticas de Ricardo Palma en sus dos obras lexicográficas: Neologismos y americanismos y Papeletas lexicográficas" (2014).

Finalmente, Alberto Sandro Chiri-Jaime, escribe una disertación sobre nuestro autor con título El imaginario nacional en "Las tradiciones peruanas" de Ricardo Palma (2012). En ella explora varias tradiciones en las que emerge la temática de la emancipación, el primer militarismo (1827-1879,) y la Guerra Del Pacífico (1879-1883). En el artículo "Las Tradiciones en salsa verde como textos carnavalizados" (2005), Luis Chambilla Herrera habla sobre el papel de lo carnavalesco en la obra palmina, con el que Palma se burla de la rigidez de las estructuras e instituciones sociales. Francisco Martínez Hoyo, en "La mirada del otro. Ricardo Palma y España" (2013), estudia la perspectiva y la actitud de Palma hacia España y los españoles, mezclando historia y leyenda desde la conquista hasta la independencia. Gonzalo Portocarrero escribe La urgencia por decir nosotros: los intelectuales y la idea de nación en el Perú republicano (2015), un trabajo que se centra en varios autores peruanos decimonónicos y dedica un capítulo sobre Palma, señalando su papel en la cristalización de la cultura criolla. Finalmente, Osmar Gonzales en su artículo "La correspondencia de Ricardo Palma" (2009), entre otras cuestiones, recoge el testimonio de Palma y su actitud hacia las Tradiciones, ya que el autor se considera un "cronista del pueblo" que copia y da color a la realidad. 
La crítica que explora la otredad en Palma se ha centrado en aspectos muy específicos de la realidad decimonónica, mostrando un interés casi casi exclusivo por la mujer, el afroperuano o el indígena, entre otros. Mi interés, por otra parte, se halla precisamente en las conexiones entre estos subalternos y en la presencia de imágenes categóricas que los definen y aúnan, desdibujando sus diferencias. Propondré que los estereotipos asociados con cada uno de estos grupos y el miedo hacia su potencial cooperación se convierten en instrumento para reforzar la ideología dominante y legitimar el poder institucional, justificando el control y la sumisión de estos cuerpos refractarios. La contribución principal de esta disertación a los estudios sobre Ricardo Palma será su concentración en la representación de los Otros, su relación entre ellos, y su importancia en la formación de identidades (nacionales) postcoloniales. Mi hipótesis es que las élites decimonónicas formadas por criollos, mulatos, o mestizos, luchan por definir su identidad y autoproclamarse representantes de la nueva nación frente a otros grupos de subalternos, como los indígenas y los afrodescendientes, quienes, al igual que en la Colonia, quedan relegados a los espacios marginales del país. Considerando que Palma es un "pardo" que se debate entre ideas conservadoras y progresistas, las cuestiones que conciernen la representación de la otredad desde este punto de vista único quedan por ser exploradas, así como sus contribuciones a los discursos sobre la estratificación social peruana del siglo XIX. Finalmente, es importante enfatizar el rol de la producción cultural y los discursos decimonónicos en la construcción de los modelos contemporáneos de nación e identidad. Utilizando la obra de Palma, mi investigación se centrará en estas cuestiones, esclareciendo las particularidades de las nuevas configuraciones de género, nacionalidad, raza, religión, y clase, así como la 
consolidación de la ideología, nación, identidad, y poder decimonónicos. Con tales premisas espero colaborar con el desarrollo académico sobre este importante periodo en la historia y la literatura del Perú. 
2. La teoría del Otro: ideología, identidad e historia

El concepto de "Otro" ha sido ampliamente estudiado desde la antigüedad y, a menudo, su definición es extensa y de difícil interpretación. Entre otras acepciones, el "otro/a" (Other en inglés; especialmente con inicial mayúscula) se define como un individuo que, desde la perspectiva de los grupos sociales dominantes, es considerado ajeno, exótico, amenazador, o inferior, debido a sus características raciales, sexuales o culturales (entre otras) (Merriam-Webster). Esta definición es un ejemplo de la dificultad que conlleva separar aquello que se considera Otro, extranjero o ajeno, de aquello que no lo es. En el siglo XXI, en las culturas occidentales, el Otro puede identificarse como un sujeto que carece de uno o más de los aspectos asociados con un modelo muy concreto, representado por el "hombre", "blanco", "occidental", "heterosexual", "cristiano" y de “clase medio-alta". Este sujeto se considera "no marcado", frente a individuos “marcados" por presuntos "defectos" o rasgos no ideales. Aspectos como la juventud, el atractivo físico, la nacionalidad, el hecho de no tener minusvalías o de ser hablantes nativos de lenguas dominantes también pueden ser factores concluyentes en esta clasificación. Por otra parte, estos rasgos “modélicos” varían según el contexto histórico y geográfico, puesto que el ideal de una comunidad y un periodo determinados no es universal. Aquellos que reúnen todos los atributos socialmente idealizados se convierten en ejemplos de conducta, fisionomía, moral e ideología, y se utilizan como medida de cotejo frente a un Otro que carece de ellos. Se trata de un individuo "incompleto" o "impuro", poseedor de una mancha que invalida su valor en conjunto.

En el contexto decimonónico en Latinoamérica, el concepto de "mancha" aflora en la obra teatral del puertorriqueño Alejandro Tapia y Rivera, La cuarterona (1867), 
cuya protagonista es un veinticinco por ciento afroamericana, por lo que es considerada portadora de una imperfección permanente. A menudo, la negritud se trata como una mancha que no se disipa a través del enlace con blancos y la mestización, por lo que, independientemente de su situación, a estos Otros se les niega la movilidad social. En otras ocasiones, la literatura examina la condición de individuos mancillados no sólo físicamente, sino también moralmente, como se puede observar en la tradición "El Nazareno" (primera serie), donde Ricardo Palma describe a Rosa, una joven bellísima nacida en la pobreza, pero cuya rectitud moral hace que no caiga en desgracia como otras mujeres: "si ella lo hubiera querido habría cambiado su situación por el lujo y la opulencia, poniendo como otras desventuradas en subasta sus encantos. Sobre la tierra abundan viejos cínicos, que derrochan el oro para comprar las caricias de esos ángeles manchados con el lodo de la prostitución" (n.p.). Por lo tanto, aquellos individuos cuya moral queda manchada se convierten en víctimas de la exclusión social y de un rechazo que circunscribe no sólo a Otros raciales, sino también a mujeres, homosexuales, y Otros religiosos. A pesar de su estigmatización, a nivel social el rol de estos grupos marginales es fundamental, puesto que proporcionan un modelo negativo (u opuesto) que permite a las élites conservar y validar su locus privilegiado: de no existir, el Otro se crearía, puesto que es necesario para establecer una diferencia entre el "Yo superior" y un "Otro inferior".

Además del término "Otro", para este estudio utilizaremos con frecuencia el concepto de "subalterno", tal como ha sido empleado en los estudios postcoloniales y por pensadores como Antonio Gramsci, Gayatri Spivak, Edward Said, Homi Bhabha, Boaventura de Sousa Santos, y Stuart Hall. Por lo general, el término "subalterno" se ha 
utilizado para definir a grupos sociales marginados, subyugados por las élites. Este concepto ya aparece en las Tradiciones de Palma con similares connotaciones: "[1]os campaneros de los conventos ricos tenían por subalternos dos muchachos esclavos, que vestían el hábito de donados. El empleo no era, pues, tan despreciable, cuando el que lo ejercía, aparte de seis pesos de sueldo, casa, refectorio y manos sucias, tenía bajo su dependencia gente a quien mandar" ("Un virrey hereje y un campanero bellaco", segunda serie, n.p.; cursiva añadida).

Por otro lado, la ambigüedad que rodea la definición del Otro puede presentar una serie de problemas. Desde la perspectiva de una sociedad marginal, ¿se podría considerar que un individuo perteneciente a un grupo dominante constituye un Otro? Es decir, ¿podría un colectivo desfavorecido desdeñar o rechazar a un "Otro dominante”? En este caso, se trata de un fenómeno diferente. Habitualmente, el sentimiento del sujeto marginal no es de superioridad o paternalismo, sino de resentimiento hacia el modelo hegemónico representado por el "Otro dominante". Mientras el subalterno puede sentir rechazo hacia este grupo, normalmente, sus acciones y actitud no comportan repercusiones a gran escala para el colectivo dominante. Sin embargo, el caso contrario conlleva todo tipo de consecuencias, dificultando el desarrollo social del subalterno, quien llega a ser a ser la principal víctima de toda injusticia social. Al ser consciente de su situación desfavorecida, el Otro es impulsado a legitimar su posición dentro de su comunidad. Mientras los grupos dominantes no necesitan hacer tal esfuerzo, el subalterno se siente en constante obligación de demonstrar y reivindicar su valor moral e intelectual, su nacionalidad, su afiliación religiosa, o su sexualidad, entre otros. Sin embargo, todo intento de validación externa suele resultar en un esfuerzo vano por parte del Otro, puesto 
que el estigma es producto de un largo proceso histórico de difícil contienda, ligado a intereses políticos y económicos. Este proceso ideológico emana de modelos como el eurocéntrico, el androcéntrico, y el etnocéntrico cuyo objetivo es el de beneficiarse del subalterno. En la era de la información, estos modelos son más inflexibles y universales que nunca, por lo que los discursos sobre los defectos atribuidos a los Otros son interiorizados por estos hasta el punto de convertirse en parte de su identidad.

En ocasiones, los grupos marginales se pueden oponer a los dominantes, aspirando rescatar ciertas costumbres o rasgos asociados con su identidad social. Ejemplo de ello son las estrategias utilizadas para enfrentarse a la "estigmatización lingüística" -el rechazo de ciertos grupos debido a su idioma. Este fenómeno, estudiado por lingüistas como William Labov, revela que las variedades lingüísticas utilizadas por las élites tienden a gozar de un "prestigio abierto" (overt prestige en inglés), creando un sentimiento de oposición -incluso violenta- a las lenguas minoritarias (Trudgill; Labov 23-24; Coupland 43). A las variantes dominantes a menudo se les otorga la condición de lenguas "standard", presuponiendo la uniformidad de las mismas y homogeneizando la diversidad lingüística (Coupland 43). No obstante, en ocasiones las variedades estigmatizadas son reivindicadas con el fin de destacar no sólo su valor, sino también las identidades sociales, étnicas, religiosas o de género que las acompañan. En este caso, se trata de un "prestigio encubierto" (covert prestige en inglés), puesto que la variante lingüística es valorada por la minoría que la utiliza, pero sigue siendo víctima del “desprestigio abierto" del discurso social (43). En el contexto peruano, podemos considerar que el español goza de un "prestigio abierto" y el quechua, u otras lenguas nativas, de un "prestigio encubierto". En efecto, a pesar del menosprecio que en 
ocasiones sufre dentro del marco nacional decimonónico, desde la segunda mitad del siglo XIX, el quechua es revalorizado por corrientes como el indigenismo y el indianismo.

Ricardo Palma pone énfasis en la riqueza de la lengua peruana, rica de vocablos en quechua, con el objetivo de rescatar tanto las variedades lingüísticas americanas con sus libros Neologismos y americanismos (1896) y Papeletas lexicográficas (1903), como las costumbres peruanas y criollas en sus Tradiciones (1872-1910). Ambas cuestiones afloran en Papeletas, donde el autor reivindica que “[m]ás que los doctos, de suyo engreídos y autoritarios, es el pueblo quien crea las palabras y el uso quien las generaliza... Mucha gracia me hace aquello de que, en un Diccionario, sólo deben estamparse las palabras de uso literario y culto, desdeñando las vulgares del pueblo... No me explico el ideal de belleza tratándose de palabras" (Papeletas vi, cursiva del original). De este modo, Palma argumenta que el léxico aceptado por la Real Academia Española es "anémico" e incapaz de abarcar el amplio y colorido pensamiento humano, y condena, al mismo tiempo, el rechazo peninsular hacia los vocablos hispanoamericanos, que contribuye a la exclusión de los colectivos más humildes (vi-vii).

El "prestigio encubierto" dentro del contexto lingüístico puede trasladarse a otros aspectos de la relación entre grupos sociales. Los sujetos que sufren por la infamia asociada con su condición económica, cultural, lingüística, racial, religiosa, o sexual, entre otras, pueden reivindicar su posición social, resaltando sus rasgos distintivos. Esta situación emerge cuando las clases humildes o los Otros raciales emulan a la burguesía 
blanca o criolla. En ocasiones, los primeros no reconocen su condición de subalternos, adoptando las costumbres, el atuendo o el habla de clases sociales o etnias dominantes. ${ }^{4}$

Los discursos que se forman con el propósito de mantener las desigualdades sociales, por lo tanto, crean un "Otro", una imagen estereotipada y homogénea, un "tipo" carente de complejidad. Tal como indica Edward Said en Orientalismo (1978), es importante subrayar que esta imagen negativa no existe de manera independiente, sino que es creada y configurada por mecanismos ideológicos y, si dejara de existir, otra imagen estereotipada pasaría a ocupar su lugar (1-2). Esta estrategia se utiliza para conservar las jerarquías sociales y el poder en manos de unas minorías, justificando la explotación del subalterno. Su inferioridad se configura como algo intrínseco, convirtiéndole en un sujeto inepto para los cometidos más elevados. En otras ocasiones, tal como afirma Alan Sinfield en Faultlines (1992), a pesar de su marginalidad, el Otro puede convertirse en una figura central, al hallarse en un espacio considerado subversivo y seductor para los grupos dominantes (299). El Otro propicia fantasías de libertad y trasgresión, por lo que cobra poder de negociación, adquiriendo visibilidad y audiencia (299). Este es el caso de la descripción de la mujer en Ricardo Palma, puesto que, a pesar de hacerse eco de la desigualdad entre géneros de la sociedad limeña decimonónica, el autor a menudo retrata a las mujeres jóvenes como seres seductores y astutos, destacando sus aspectos físicos como el "cutis de ese gracioso moreno aterciopelado que tanta fama dio a las limeñas", los "ojos más negros que noche de trapisonda y velados por rizadas

\footnotetext{
${ }^{4}$ Estos fenómenos son analizados en los artículos de Felipe Martínez Pinzón, "Una nación sin blancos", y Mercedes López Rodríguez, "Blancos de todos los colores: intersecciones entre clase, género y raza en la escritura costumbrista colombiana del siglo XI", y en el libro de Juan de Castro, Mestizo Nations, donde analiza estas cuestiones en la obra de Palma.
} 
pestañas", la "boca incitante, como un azucarillo amerengado", el "cuerpo airoso", y, finalmente, "un pie que daba pie para despertar en el prójimo tentación de besarlo" ("La gatita de Mari-Ramos", segunda serie, n.p.).

El paralelismo ideológico que se establece entre distintos Otros en la América postcolonial constituye un "agravante" en su situación social. En el estudio de la alteridad podemos observar lo que yo llamaré una "Otredad plural" y una "Otredad por aproximación". Con la primera, me refiero a los individuos considerados portadores de múltiples rasgos "indeseables", como es el caso de la mujer que pertenece, además, a una minoría étnica. La Otredad por aproximación se produce cuando existe un acercamiento entre subalternos, como puede ser la unión entre mujeres y Otros extranjeros. Esta coalición es a menudo considerada una doble amenaza, causante de "desequilibrios" sociales como el mestizaje. ${ }^{5}$

Finalmente, los conceptos de "identidad" y "subjetividad" están fuertemente vinculados con el de otredad. En líneas generales, la subjetividad está relacionada con las estructuras de "poder" y puede entenderse tanto como nuestra propia manera de entender nuestro lugar en el mundo, como el modo en el que otros nos consideran dentro del mismo. Según Louis Althusser (1918-1990) el individuo es, al mismo tiempo, el destinatario y el agente de las ideologías que le convierten en un "sujeto" subyugado (Weedon 6). Althusser afirma que las instituciones religiosas, familiares, políticas y culturales, entre otras, producen una serie de ideologías con las cuales nos identificamos; asumimos nuestras identidades y, al mismo tiempo, nos convertimos en "sujetos" de la

\footnotetext{
${ }^{5}$ Véase el libro El juego de las apariencias. La alquimia de los mestizajes y las jerarquías sociales en Lima, siglo XIX (2017) de Jesús Cosamalón Aguilar.
} 
ideología dominante (Weedon 6). Asimismo, tal como señala Chris Weedon, la "identidad" es bipartita: puede vincularse con la manera en la que un individuo "se define a sí mismo" (por ejemplo, una mujer, de color, occidental), o con un conjunto de "descripciones sobre el individuo asignadas por instituciones y sociedades" -como es el caso del género y la nacionalidad (6). Estas identidades impuestas se manifiestan y son corroboradas por los propios individuos (como es el caso de la forma de vestir de hombres y mujeres), por lo que, a menudo, son interiorizadas por estos (6).

James Fearon describe la identidad como (a) una categoría social, que se otorga a un individuo o colectivo por sus (supuestos) atributos o comportamientos característicos; y (b) un conjunto de rasgos distintivos que el individuo considera inamovibles y/o fuente de orgullo (1). Ambas son construcciones personales o sociales (identidades de grupo) y, a menudo, no guardan relación con la realidad que designan. Tal como indica Fearon, la identidad es cardinal en la formación de los nacionalismos, los conflictos étnicos, y en las cuestiones de género y sexualidad (1). Asimismo, según Geert Hofstede, el concepto de identidad a menudo es relacionado con el de cultura, puesto que los términos pueden mezclarse y confundirse (10). Las "identidades" responden a la pregunta ¿a qué lugar pertenezco?, y no se basan en valores, sino en imágenes mutuas, estereotipos y emociones sobre aspectos sociales y personales externos (10). Hofstede indica que las identidades son subjetivas, puesto que no son insólitas las luchas entre grupos que, a pesar de compartir los mismos valores, consideran que sus identidades son opuestas (10). En otros casos, una identidad compartida, a menudo requiere la creación de un Otro común, por lo que puede producirse una unión entre grupos rivales, como es el caso de 
las distintas regiones de un país que luchan en conjunto en el momento de enfrentarse a un “enemigo” común (10).

2.1. Nexo entre pasado y presente decimonónico. Orientalismo, civilización y barbarie Los conflictos medievales y premodernos entre países europeos y del Oriente Medio marcaron fuertemente el antagonismo entre estos dos territorios (reales o imaginarios), alimentando las ideologías sobre su incompatibilidad por cuestiones étnicas, políticas y religiosas entre otras. ${ }^{6}$ Edward Said define el Orientalismo como la corriente de pensamiento que se centra en la ruptura epistemológica y ontológica entre “Oriente" y "Occidente" desde una perspectiva decimonónica británica y francesa (1-2). En este contexto el Oriente se visualiza como un lugar lejano, tanto física como temporalmente, hogar de las más ricas y antiguas colonias de Occidente, al igual que de sus mayores enemigos (1-2). Según Said, el Oriente es fuente de las imágenes más profundas y recurrentes del Otro, creando un imaginario que, a su vez, colaboró en la definición de Occidente (1-3). Por consiguiente, el mundo occidental cobró su fuerza e identidad al compararse con este espacio rival ajeno y, en gran parte, imaginario (1-3). Sin embargo, en la Edad Media y la era premoderna, cuando Europa dirige su mirada hacia Oriente no lo hace desde una perspectiva colonialista. En sus momentos de mayor esplendor, los poderosos imperios de Oriente, como el persa, el otomano, o el mongol, poseían un dominio militar y económico que superaba con creces a las potencias

\footnotetext{
${ }^{6}$ Véase Carolina Alzate, "Modos de la metáfora orientalista en la Hispanoamérica del siglo XIX. Soledad Acosta, Jorge Isaacs, Domingo F. Sarmiento y José María Samper. Modes of the Orientalist Metaphor in Nineteenth-Century Hispanic America. Soledad Acosta, Jorge Isaacs, Domingo F. Sarmiento and José María Samper". Taller de Letras, núm. 45, 2009, 131-43.
} 
europeas. Destacan los encuentros entre Oriente y Occidente que tienen lugar durante las cruzadas papales, entre 1096 y 1291, en las que cristianos y musulmanes luchan por imponer su potestad sobre la Tierra Santa, culminando con la derrota de los europeos. Asimismo, la Conquista musulmana de la Península ibérica por el Califato Omeya en el año 711 , da pie a cerca de ocho siglos de convivencia entre musulmanes y cristianos y termina con la "Reconquista" del último reducto árabe en la Península por parte de facciones cristianas en 1492. Esta es considerada por muchos como la última de las cruzadas.

Es precisamente la imagen del Oriente que se crea en este periodo en Europa y España la que más tarde se traslada hacia el Nuevo Mundo (Tyutina 179). A menudo, el Otro es considerado un "extranjero" en su propia tierra, tal como demuestran las expulsiones de moriscos y judíos, quienes pueblan la Península durante nueve siglos hasta que muchos son desterrados entre 1609 y 1613 durante el reinado de Felipe III. Estos choques se mencionan en la obra de Palma, quien utiliza frases hechas sobre los “moros de Granada” (el último bastión perdido por los musulmanes en la Península en 1492), y anécdotas sobre la obsesión peninsular sobre la "limpieza de sangre” ("Una carta de indias", segunda serie, n.p.). Este concepto es utilizado por los españoles tras 1492 , puesto que los cristianos buscaban "legalizar" el nominal hecho de no tener antepasados musulmanes o judíos: “[e]1 descendiente de un moro de África venía de España diciendo que en su familia no se habían conocido negros; y el hombre más soez se presentaba con un cartucho de papeles, llenos de arabescos y garabatos, para probar que descendía de la casa más noble de Asturias o Vizcaya" (Palma, "Los alcaldes de Arica", cuarta serie, n.p.). 
De manera similar, los conquistadores españoles pretenden diferenciarse de los pueblos del Nuevo Mundo, importando las ideas sobre la "limpieza de sangre" en las Américas. Entre otras estrategias utilizadas para la exclusión destaca la "orientalización" o “extranjerización” de sus habitantes, una ideología utilizada por los conquistadores para alegar que los nativos provienen de Asia y legitimar, de este modo, su colonización (Camayd-Freixas 1). En el caso del Perú, las imágenes sobre Oriente se aplican a diversos tipos de subalternos, como es el caso de afroperuanos, indígenas y asiáticos, estos últimos trasladados principalmente desde China debido a la necesidad de mano de obra para el sector agrario y el negocio del guano entre 1845 y 1871 (Watson, "Presencia” 182). En las Tradiciones de Palma se hacen numerosas menciones sobre el Otro oriental, como veremos en el Capítulo 6.

Al igual que el Oriente, el Nuevo Mundo se retrata como una imagen sucedánea, invertida y oscura de Occidente, asociada con estereotipos como la opulencia, la sensualidad y, sobre todo, la crueldad (Said 3, 4). Es posible trazar un paralelismo entre la descripción del Oriente y los discursos sobre las tierras y los habitantes del Nuevo Mundo, poblado por seres fantásticos y antinaturales y hogar de tesoros grandiosos. Por consiguiente, se difunden leyendas sobre espléndidas ciudades inaccesibles e imaginarias, como el del famoso El Dorado, y se exagera el valor de parajes remotos como la Xauxa (Jauja) en el Perú. En la Edad de Oro, las descripciones sobre la Jauja se ajustan a la creencia de que el paraíso terrenal se encontraba en América. Sin embargo, a finales del siglo XVI, el Nuevo Mundo y, especialmente, la ciudad de Lima, se convierten en el centro del "mundo al revés", la capital de "lo carnavalesco-grotesco, el desenfreno y la 
opulencia”, dejando a un lado su acepción mítica y paradisiaca (Velázquez, Mirada 29, 32-33).

A pesar del tópico europeo que tiende a describir un Nuevo Mundo sin pasado ni historia, los colonos encuentran un continente poblado por tribus de nativos y por las importantes civilizaciones inca (1438-1533), azteca (1300-1521), y maya (c. 2000 a.C.1697) (esta última ya en declive a finales del siglo XV). En el contexto decimonónico, los imperios precolombinos son objeto de fascinación y son retratados, entre otros, por Ricardo Palma, quien hace una extensa descripción de estas civilizaciones, si bien de forma simplista y distante. En sus distintos periodos de apogeo, estas sociedades de Mesoamérica y los Andes, contaban con una importante organización política y territorial, una extensa red comercial e importantes sistemas agrícolas y ganaderos (Larson 9-10). Por consiguiente, el periodo colonial americano está marcado por una tumultuosa relación entre los habitantes del Nuevo Mundo y los europeos, cuyos primeros testimonios sobre estas tierras quedan plasmados en documentos de viaje, crónicas, diarios o relaciones.

Lejos de ser ejercicios de observación y catalogación objetiva, estos escritos destacan por su contenido pseudo-histórico, mezclando opiniones y ficción con sucesos verídicos. Ejemplo de ello son las obras de colonos y descendientes españoles como los Cristóbal Colón (c. 1436/51- 1506), Bernal Díaz del Castillo (c. 1492/98-1584), Álvar Núñez Cabeza de Vaca (c.1488/90-c.1557/58), Bartolomé de las Casas (c.1474/84-1566), Fray Antonio de la Calancha (1584-1684), y del misionero jesuita José Acosta (c. 15391600), quienes proporcionan las primeras descripciones del encuentro entre civilizaciones. Asimismo, sobresalen los testimonios de criollos peruanos como el Inca 
Garcilaso de la Vega (1539-1616) y Felipe Guamán Poma de Ayala (1534-1615), quienes facilitan un punto de vista distinto al de los colonos. Sus perspectivas son una muestra de las primeras y sutiles oposiciones contra el poder imperial por parte de nativos y, más tardes, criollos. Sin embargo, en la última etapa colonial y durante el periodo postcolonial, las diatribas contra los conquistadores se intensifican y se convierten en un tema recurrente, inspirando a obras como Lima fundada o Conquista del Perú (1732) de Pedro Peralta y Barnuevo (1663-1743), las Tradiciones de Ricardo Palma (1833-1919), y las obras indigenistas o indianistas de Clorinda Matto de Turner (1852-1909) y Manuel González Prada (1844-1918). Los testimonios de los primeros cronistas son de vital importancia en la creación de la imagen del Otro americano en épocas posteriores, y son fuente de inspiración de buena parte de las Tradiciones de Palma. Tales ideas son especialmente significativas en el contexto decimonónico cuando toman forma los nuevos conceptos de nación y sus habitantes luchan por afianzar su posición social.

El objetivo de muchos de los primeros cronistas y exploradores del Viejo Mundo es el de dar constancia sobre el uso de los bienes proporcionados por los patrocinadores de sus viajes, ya que las expediciones de conquista del siglo XVI eran empresas de negocio subvencionadas por inversionistas europeos. Sin embargo, su propósito también es el de favorecer futuras empresas, por lo que, a menudo, se apresuran por corroborar la presencia de nativos dóciles, una potencial mano de obra económica para todo inversor interesado en la explotación de los recursos del continente. Con el fin de impulsar el proyecto colonial, los escritores procuran además aderezar sus narrativas con elementos sensacionalistas sobre las riquezas y los habitantes de estas tierras, distorsionando, voluntaria o involuntariamente, la realidad del Nuevo Continente. En las crónicas del 
periodo, no es infrecuente la incorporación de elementos bíblicos, junto a pasajes inspirados en obras como la Historia Natural de Plinio el Viejo (c. 23-c. 79 d.C.), la Relación del primer viaje en torno al globo de Antonio Pigafetta (c. 1480-c. 1534) y las descripciones del Oriente de Marco Polo (c. 1254-1324) (Pastor 7-8). Del mismo modo, se añaden elementos de la mitología europea y las leyendas medievales, adaptándolos a las circunstancias y los fenómenos hallados por los primeros exploradores. Surgen así testimonios sobre la existencia de seres sobrenaturales, gigantes, sirenas, y hombres con cola o cabeza de perro, quienes envuelven al continente en un halo de misterio (Pastor 13). Tales recursos cumplen una función doble: hablan sobre la amplia disponibilidad de nativos para las empresas europeas y los deshumanizan o bestializan para justificar su explotación.

La retórica utilizada por los primeros colonos enlaza el imaginario sobre el Nuevo Mundo con la economía, con un fin comercial y de instrumentalización del continente (Pastor 45). De este modo, los colonos inauguran una importante corriente ideológica sobre los nativos con dos puntos de vista opuestos, utilizados de manera alternada según los intereses coloniales. Por un lado, el indígena es considerado un ser inocente y puro, un "buen salvaje" (o "noble salvaje") que habita lugares paradisíacos, pero es excluido de la redención espiritual cristiana, puesto que se halla en un "entorno natural" más "animal" que humano. Por otro lado, los nativos son descritos como producto de una aberración natural, unos seres bárbaros y paganos, asociados con el bestialismo y la monstruosidad. Tales retratos revelan una intencionalidad bipartita: por un lado, los nativos son deshumanizados para justificar su explotación y, por otro, se les niegan los derechos 
europeos a pesar de su conversión al cristianismo debido a su "barbarie" e "impiedad" innatas. $^{7}$

Uno de los primeros ejemplos de avasallamiento de los nativos son las ordenanzas de la Corona española como el Requerimiento, implantado desde 1513 (Milanich 65). Este contrato otorgado a los colonos proporcionaba a los conquistadores no sólo el derecho, sino también el deber de requerir a los habitantes del Nuevo Mundo (en este caso, en la Florida) su sometimiento incondicional a los reyes españoles. Tal documento es una prueba más de la división entre conquistadores españoles y los subalternos de ultramar. Otro ejemplo conocido es el de la Encomienda, una institución creada por la Corona española que los obliga a pagar con bienes y servicios la nominal protección de los colonos. Asimismo, los encomenderos debían comprometerse a instruir a los indios en la religión católica, y, si estos no se sometían a la voluntad de la Corona y la Iglesia, a menudo su pena era el castigo corporal o incluso la muerte (Doucet 43).

Entre los primeros cronistas peruanos que se hacen eco de la situación, destacan el indígena Felipe Guamán Poma de Ayala y el escritor criollo Gómez Suárez de Figueroa, más tardes bautizado con el nombre de Inca Garcilaso de la Vega. Por su parte, el Inca Garcilaso analiza la historia desde el punto de vista de indígenas y mestizos, puesto que se identifica con este último grupo. Fruto de la unión extramatrimonial entre el noble capitán español Sebastián Garcilaso de la Vega y la princesa inca Isabel Chimpu-Ocllo, El Inca Garcilaso es un representante de la otredad a distintos niveles: es un criollo, un

\footnotetext{
${ }^{7}$ Véase Beatriz Pastor, Discurso narrativo de la conquista de América (pp. 52-53), sobre los diarios de Cristóbal Colón, en los que el navegante habla sobre la facilidad de someter los nativos americanos para utilizarlos como mano de obra.
} 
mestizo y un hijo ilegitimo, hablante del quechua, pero educado según la tradición europea (Hernández 227). El Inca Garcilaso es autor de crónicas como la Florida del Inca (1605) y los Comentarios reales, una obra dividida en dos partes, la Primera parte de los Comentarios Reales (1609) y la Historia General del Perú (1617). ${ }^{8}$ En calidad de mestizo, el trabajo del Inca Garcilaso se caracteriza por ser un producto híbrido, ya que defiende a la comunidad nativa, pero pretende abrirse paso entre las altas esferas de la Colonia típicamente ocupadas por europeos blancos. Como mestizo, El Inca Garcilaso se halla en una posición ambigua o incluso marginal, por lo que se ve en la obligación de legitimar constantemente su rol dentro de la Colonia.

El trabajo del Inca Garcilaso es una importante fuente de información para autores coloniales o postcoloniales como Ricardo Palma. Los Comentarios no sólo afectan la ideología posterior, sino que son utilizados para otorgar veracidad y fundamento histórico en algunas obras como las Tradiciones palminas. Entre ellas, destaca "Carta canta" (tercera serie), en la que se reescribe uno de los relatos de los Comentarios, donde se parodian las creencias y la lengua de los indígenas y su desconocimiento de la escritura europea. En el relato, El Inca Garcilaso utiliza como base de su texto una anécdota humorística sobre dos indígenas quienes malinterpretan la función de las cartas, atribuyéndoles poderes sobrenaturales: "no sabían qué eran letras, entendían que las cartas que los españoles se escribían unos a otros eran como mensajeros que decían de palabra lo que el español les mandaba, y que eran como espías que también decían lo que veían por el camino" (502). Otras fuentes fuertemente utilizadas por Palma para retratar

\footnotetext{
${ }^{8}$ La Florida del Inca es una obra canónica del periodo colonial en la que muchos pasajes se inspiran en las célebres crónicas de Álvar Núñez Cabeza de Vaca, recogidas en su libro Naufragios (1542).
} 
el primer siglo de la Colonia fueron las crónicas de Fray Antonio de la Calancha (15841684), Crónica moralizada del Orden de San Agustín en el Perú (1638), y del misionero jesuita José Acosta (c. 1539-1600), autor de la Historia natural y moral de las Indias (1589). Tal como se analizará en el Capítulo 3, podemos observar cómo los discursos sobre el Otro que empiezan a gestarse en los albores de la Colonia siguen vigentes en épocas posteriores y son recogidos y reescritos por autores postcoloniales.

Aunque les separan varios siglos, en ocasiones el nexo entre autores premodernos como El Inca Garcilaso y decimonónicos como Palma es su condición liminal. En calidad de criollos y mestizos peruanos, los escritores a menudo critican de manera implícita o explícita sus sociedades, mostrando una actitud ambigua hacia la Colonia. Por una parte, denuncian sus prácticas abusivas contra los indígenas y los afrodescendientes, hacia los que sienten cierta afinidad; por otra, en su obra aflora un distanciamiento hacia estos grupos marginales, revindicando su lugar privilegiado como criollos o miembros de las élites. Con este fin, llevan a cabo un enaltecimiento de su herencia hispánica, ubicando la Conquista en una esfera mítica y providencial donde los colonizadores y los colonizados representan a una dicotomía que enfrenta civilización y barbarie, luz y oscuridad, fe y apostasía.

Las desigualdades sociales y los sistemas jerárquicos que se cristalizan durante la Colonia se redistribuyen, reorganizan y amoldan a la nueva situación social tras los movimientos de emancipación en Latinoamérica. Aunque en 1821 se declara la soberanía de la República del Perú, la Península hace varios intentos de reconquistar al país y otros territorios americanos sin éxito (Mannarelli, Limpias 13). La corona española no reconoce la emancipación hasta 1879, por lo que, incluso en la época de Palma, las 
polémicas sobre la independencia y los efectos de la Colonia siguen muy presentes. ${ }^{9}$ Las desigualdades sociales persisten en todos los aspectos de la vida en una etapa de crisis ideológica e identitaria, en la que se cuestiona el régimen anterior pero se mantiene una estructura social patriarcal en la que una minoría criolla o blanca, de origen europeo, conserva la mayor parte de las riquezas y del poder. Los derechos que anteriormente estaban en manos de colonos blancos pasan a ser relativamente accesibles para otras etnias, pero el cambio no es homogéneo. En la jerarquía establecida por los españoles el color de la piel se vincula al estatus social, y los individuos no blancos se hallan en una posición desfavorable. Asimismo, a pesar de haber logrado la independencia, Perú no reconoce la abolición de la esclavitud hasta 1855 , síntoma de la influencia del sistema de castas-clases (Fisher 83). Para que la estructura jerárquica no se derrumbe, no sólo es importante silenciar y ejercer un fuerte control sobre las etnias oprimidas, sino también sobre las libertades de todo enemigo externo -o extranjero-, político, religioso o interno -como es el caso de las mujeres y las clases sociales desfavorecidas.

Asimismo, en el siglo XIX se produce un movimiento de inmigración desde las zonas rurales hacia las ciudades, atraídos por la floreciente industria y su demanda de mano de obra (Velázquez, Mirada 248; Valero, "Trayectorias" 20). A menudo los protagonistas de este movimiento migratorio -amerindios en su mayoría- forman barrios marginales u obreros y son culpados por la degradación de las urbes y la mezcla étnica (Velázquez, Mirada 248). El deterioro urbano también se asocia con la corrupción física

${ }^{9}$ El 28 de julio de 1821 se declara la soberanía de la República del Perú, producto de la Guerra de Independencia Hispanoamericana, y se afianza el 9 de diciembre de 1824 con la Batalla de Ayacucho (Paso 518). Por su parte, la corona española no reconoce tal emancipación hasta 1879, durante la Guerra HispanoSudamericana (518). 
y moral de la sociedad en conjunto, considerándose que, debido a los subalternos y al mestizaje, los cuerpos se vuelven viciados, enfermos, racialmente debilitados, o incluso afeminados. De la degeneración física, a menudo se culpa a la mujer y su "irresponsabilidad", ya que "elige mezclarse" con los Otros, transmitiendo los rasgos "perniciosos" a su prole. ${ }^{10}$

Tras la emancipación, junto al deterioro urbano se inicia un proceso de declive económico que acentúa el sentimiento de frustración peruano. A partir de 1845, crece la demanda de guano, un fertilizante natural que es exportado al exterior del Perú, un negocio que contribuye, en cierta medida, a la mejora financiera del país. Sin embargo, el éxito económico no se dispersa por toda la nación, y su auge es eclipsado por otras circunstancias adversas, como la Guerra del Pacífico (1879-1883), en la que (junto a su aliada, Bolivia) el Perú sufre una clamorosa derrota contra Chile. El descontento social se manifiesta en los discursos decimonónicos, en los que, en ocasiones, se critica el estancamiento del Perú en el pasado colonial, mientras que, en otras, se describen los tiempos del Imperio con nostalgia, especialmente en su capital, que todavía mantiene "la imagen aristocrática de la antigua ciudad colonial" (Valero, "Trayectorias" 20). Esta alternancia se percibe en los discursos de muchos peruanos que abogan por la renovación, pero se sienten frustrados por el declive que conlleva el cambio de régimen (21).

Aun siendo fieles defensores de la independencia, autores como Ricardo Palma, no dejan de ser tradicionalistas que pretenden preservar "la imagen bucólica de la Lima

\footnotetext{
${ }^{10}$ Marcel Velázquez Castro defiende un argumento similar al indicar que la mujer decimonónica es considerada la responsable de la homosexualidad, debido a la educación materna de los niños en los primeros años de vida (Mirada 145).
} 
colonial" y aislar las clases sociales marginales, culpadas en buena medida por su deterioro (Valero, "Trayectorias" 21). La actitud ambigua de Palma, su admiración y simultaneo rechazo hacia la influencia peninsular, sugiere la existencia de una crisis identitaria presente en una sociedad que, al enfrentarse a un futuro incierto, dirige su mira hacia un pasado idealizado, ordenado y jerárquico. Las ambiguas actitudes hacia otras clases o etnias derivan de la negociación entre dos estados psicológicos. Por una parte, los peruanos pretenden afianzar su lugar en la sociedad postcolonial; por otra, heredan la obsesión peninsular por el linaje y su quimérica lucha por obtener la idealizada limpieza de sangre española. Puesto que incluso en las élites peruanas existe una marcada mezcla étnica, se produce un conflicto identitario que alterna el rechazo con la aceptación hacia la diversidad. La obra de Palma ayuda además a discernir en qué medida los discursos ambiguos hacia las etnias afectan las identidades (nacionales) peruanas en una época en la que la creciente burguesía mestiza criolla aspira a obtener el reconocimiento social asociado con los blancos europeos.

A medida en que el Perú avanza hacia el siglo XX, la situación económica del país empieza a estabilizarse. Se afianza la cimentación de un Estado nacional y se forma una oligarquía peruana que se establece en el poder hasta la segunda mitad del siglo XX (Oliart 261). El resultado de esta consolidación hace que se construya una imagen muy definida sobre el país y sus habitantes, especialmente en cuanto a los roles de cada grupo étnico, clase y género (261). Las imágenes que se forman no son necesariamente veraces, pero son un instrumento para que las elites afiancen su poder sobre el resto de la población (262). A pesar de originarse en la Colonia, la división social y el racismo de 
este periodo toma una forma muy específica, influenciada por las ideas darwinistas y el "racismo científico", con el objetivo de establecer un nuevo orden social en el país (262).

2.2. Ciencia y determinismo: barbarie, bestialismo y monstruosidad

Existe un nexo entre conceptos aparentemente dispares, como "cultura", "moral", "raza", "geografía”, "naturaleza”, "fisiología”, "índole”, "genética” y “conducta”. Estos términos son a menudo utilizados como arma en lo que llamaré "estigmatización o difamación cultural", el acto de ridiculizar, avergonzar y desacreditar a un individuo o colectivo debido a sus costumbres o semblantes (reales o atribuidos). Ejemplo de ello es el uso de términos como "raza", etnia, o incluso fenotipo; este último, definido como el conjunto de características observables en un organismo que resultan de la interacción entre el genotipo (la herencia genética) y el medioambiente (Real Academia). ${ }^{11}$ Cuando tales términos se aplican al ser humano, a menudo forman parte de una retórica de exclusión de ciertos sectores de la población, puesto que la ciencia no establece divisiones netas entre seres humanos dependiendo de factores como el color de la piel. Otro concepto ambiguo es el de "cultura", que a menudo engloba a un amplio conjunto de costumbres, rasgos y conductas discordantes atribuidas a un colectivo determinado. Con frecuencia, la idiosincrasia es trazada por individuos ajenos al grupo representado, y sus perspectivas son impuestas sobre ese colectivo que, finalmente, llega a adoptar y asimilar esa visión externa y estereotipada sobre sí mismo.

${ }^{11}$ Véase el artículo de Álvaro Sarco, "Irresueltos discursos del canon cultural peruano" (2005), en el que habla sobre cuestiones como la "superioridad biológica" de una "raza" sobre otra, el determinismo cultural y de clase, y el mestizaje, subrayando el hecho de que el racismo se encuentra fuertemente enraizado en la sociedad peruana. 
A la hora de describir un sujeto o colectivo y su "cultura", las diferencias individuales se silencian a favor de una imagen que abarca a toda la comunidad. En su tercera definición del término "cultura", el diccionario de la Real Academia Española presenta el concepto como un "[c]onjunto de modos de vida y costumbres, conocimientos y grado de desarrollo artístico, científico, industrial, en una época, grupo social, etc.” (n.p.). Si tomamos de ejemplo esta definición, podemos observar como otorga una perspectiva limitada y uniforme sobre el ser humano. La idea de que las culturas son homogéneas y representan un conjunto de costumbres, o que influencian al individuo independientemente de sus acciones, resultan inadecuadas (Spencer-Oatey 16). No existe una cultura única y a gran escala, por lo que no se puede hablar de una cultura nacional, regional, o incluso tribal (16). De manera casi universal, el individuo se identifica simultáneamente con varios grupos sociales, estructuras e instituciones (16). Por otro lado, este es precisamente el proyecto de Ricardo Palma, quien se propone retratar las costumbres de Lima y del Perú de manera muy genérica, haciendo un retrato artificial de su sociedad.

Así encontramos tradiciones como la de "La achirana del Inca" (tercera serie), en la que Palma describe a los incas de la época precolombina. Según el autor, en "1412 el inca Pachacutec... emprendió la conquista del valle de Ica, cuyos habitantes, si bien de índole pacífica, no carecían de esfuerzos y elementos para la guerra” (n.p.). Este pasaje, el autor pudo basarse inadvertidamente en dos estereotipos sobre los indígenas. Por un lado, los indios son descritos como "buenos salvajes" de índole pacífica y, por otro lado, sin la supervisión adecuada pueden dar muestra de su "barbarie" innata, ya que no carecen de recursos para la guerra. Este tipo de discursos describen al nativo de manera 
determinada, impidiendo que este construya su propia identidad y el carácter múltiple de su sociedad. Lo mismo sucede en las descripciones de los personajes femeninos, como en “Capricho de limeña" (tercera serie), tradición en la que Palma indica que "la mujer esgrime la lengua, arma ofensiva y defensiva que la dio naturaleza" (n.p.). Al aludir al concepto de "naturaleza" el autor instituye una analogía entre comportamiento y condición biológica, trazando un paralelismo entre conducta, herencia y entorno cultural o geográfico.

Las imágenes simplificadas y deterministas de Palma no se limitan a describir al Otro racial o de género. A la hora de retratar a extranjeros como los que él llama los "hijo[s] de la perezosa España, acostumbraba dormir la siesta", el autor construye un retrato estereotipado de los peninsulares, descritos, en su gran mayoría, como ociosos, ineptos y despiadados ("Mujer y tigre", primera serie, n.p.). En la tradición "Si te dieren hogaza, no pidas torta" (sexta serie), destaca su retrato del célebre conquistador Francisco de Carbajal (1464-1548), también conocido como "el demonio de los Andes" debido a su carácter sanguinario. Según Palma, Carbajal fue "hijo natural del terrible César Borgia, y por ende nieto del papa Alejandro VI", por lo que "[1]a raza no desmintió en él” y "en la sangre traía los instintos del tigre" (n.p.). De este modo, Palma enlaza biología, raza, y costumbres, dando fe de la ideología en boga en los siglos XVIII y XIX sobre el determinismo dictado por la naturaleza y la fisiología, y sus efectos sobre la "índole" y la conducta.

El concepto de tipificación humana ya aflora en los discursos de la antigüedad clásica grecorromana y es discutido por pensadores como Platón (c. 427-347 a. C.), Aristóteles (384-322 a. C.), San Agustín (354-430) e Hipócrates (c. 460 - c. 370 a. C.). 
Las taxonomías no son sólo raciales, sino que incluyen a mujeres, pobres, y otras minorías. Aristóteles afirma que las mujeres son inferiores por pertenecer a una categoría distinta a la de los hombres y que su "naturaleza" y "esencia" dictaminan su conducta y posición social (al igual los esclavos subsaharianos, entre otros) (Smith, "Plato" 467). Hipócrates se centra en la división entre seres humanos en su tratado Sobre Aires, Aguas $y$ Lugares, postulando que existen cuatro humores (sangre, bilis negra, bilis amarilla y flema) que afectan la salud y la personalidad del ser humano (Floyd-Wilson 40). Otros griegos destacados son Posidonio (c. 135-51 a. C.), quien establece un paralelismo entre "razas", geografía, clima y conducta para justificar la colonización de las sociedades “inferiores”. Finalmente, Galeno (129-c. 201/216) usa la tesis hipocrática de los humores para argumentar que la racionalidad y templanza son rasgos de las personas "flemáticas", el optimismo y jovialidad de las "sanguíneas", la melancolía de aquellas con exceso de bilis negra, y la propensión a la cólera destaca en las personas con demasiada bilis amarilla (Floyd-Wilson 40). Estas ideas científico-médicas hacían hincapié en la polaridad entre hombres y mujeres, argumentando que estas últimas tenían "un temperamento frío y húmedo, imperfecto y enfermizo", y poseían "un cuerpo desequilibrado", “destemplado y por tanto patogénico” (Beltrán 308). Asimismo, son utilizados en los discursos europeos acerca del "debilitamiento, la degeneración, el afeminamiento de los temperamentos indianos debido al temperamento inicuo de estas regiones" (308). Tales creencias tienen un fuerte impacto en épocas posteriores, tanto dentro como fuera de Europa, rediseñándose a lo largo de las distintas etapas históricas. El filósofo persa Avicena (c. 980-1037) amplía las teorías hipocrático-galenas sugiriendo que los humores tienen componentes emocionales y morales (Floyd-Wilson 212). 
Asimismo, pensadores cristianos medievales como Tomás de Aquino (1224/1225-1274), utilizan varios discursos de categorización para justificar la distribución jerárquica entre seres humanos y, por lo tanto, defender (a distintos niveles) la subordinación de niños, mujeres y esclavos (Capizzi 34; Popik 4). Sin embargo, a pesar del auge de los argumentos sobre las diferencias esenciales del ser humano, el nivel socioeconómico sigue considerándose el elemento de exclusión determinante en el tejido social.

Julie Ward señala que, en los albores de la expansión colonial europea, las categorizaciones humanas se apoyan en el elitismo cultural más que en tipificaciones "esenciales" o "biológicas" del ser humano (n.p). El comienzo del periodo colonial ha sido marcado como el inicio de la división entre "razas" tal como la conocemos el día de hoy. Sin embargo, en esta época se trata de una categorización cuyo objetivo principal es el de dividir las distintas clases-castas de las colonias, apoyándose en la clasificación "racial" de sus habitantes. Ward pone de ejemplo a John Locke (1632-1704), cuyo desdeño hacia africanos subsaharianos y nativos americanos se apoya en la posición social de esos más que en factores raciales (n.p.). Locke critica la capacidad intelectual de los indígenas del Nuevo Mundo y su condición de paganos con el propósito de justificar la expropiación de sus tierras (n.p.). Mas tarde, junto a los ideales de la Ilustración del siglo XVIII, los argumentos sobre las taxonomías humanas empiezan a desviar su atención hacia cuestiones religiosas, raciales o de género (sin desprenderse del factor socioeconómico). Los siglos XVIII y XIX son fundamentales en la formación ideológica sobre la segregación étnica, ya que se produce una unión entre racismo "cultural" y "biológico" (Ward n.p.). Aunque las raíces de la discriminación son muy arraigadas desde la antigüedad, a partir de esta época el talante elitista y esencialista anterior se 
fusiona con la ciencia biológica moderna, solidificando la idea preexistente (pero indefinida) de que existen grupos independientes de razas (n.p.).

Según Ward, tradicionalmente existen dos perspectivas desde las que se han definido las etnias: el racismo "cultural/débil" y el racismo "biológico/fuerte" (n.p.). El primero está asociado con la teoría "monogenética", la creencia de que todas las etnias tienen un origen común y que ciertas razas "degeneran" al verse afectadas por el clima, la alimentación, y la cultura (n.p). Sus diferencias son, por lo tanto, "superficiales", centrándose en aspectos como el color de la piel o las costumbres (n.p). El racismo "biológico/fuerte" a menudo se asocia con la teoría "poligenética", la creencia de que cada raza tiene un origen independiente; en este caso, comportamiento, intelecto e inclinaciones morales o políticas se consideran innatos, "esenciales" y dictados por la biología y la herencia (n.p.). El filósofo francés Voltaire (1694-1778), es un ejemplo de pensador poligenista (y deísta) que rechaza no sólo a grupos étnicos no blancos, sino también a instituciones religiosas como las judaicas y las musulmanas (Cohen, French 86). Asimismo, Voltaire opinaba que los subsaharianos no compartían completamente la humanidad "natural" de los europeos, por lo que los incluía en el reino del bestialismo $(86) \cdot{ }^{12}$

Entre los primeros pensadores que vinculan las categorizaciones culturales con las biológicas destaca el naturalista francés Comte de Buffon (1707-1788), quien afirma que los factores externos - como el clima, la comida, el nivel social y las costumbresmodifican los rasgos de las distintas razas, los cuales, a su vez, son hereditarios (Ward

\footnotetext{
${ }^{12}$ Robert Boyle (1627-1691) y Henri de Boulainvilliers (1658-1722) son otros pensadores del periodo que analizan las categorizaciones humanas.
} 
n.p.). Como monogenista, cree que todas las razas tienen un antepasado común blanco y que algunos grupos “degeneraron” hacia razas no blancas, pudiéndose revertir mediante la exposición a estímulos externos -climáticos y culturales, entre otros (n.p.). ${ }^{13}$ David Hume (1711-1776) opina que las razas humanas se hallan afectadas, en primer lugar, por factores morales o psicológicos (como la cultura y las costumbres) y, en segundo lugar, por componentes físicos (internos o biológicos; y externos, como el clima o el medioambiente) (n.p.). Al igual que otros pensadores, divide los humanos en cuatro razas humanas dominadas por la blanca, y seguida por las razas "inferiores" amerindia y asiática, hasta llegar a la negra (n.p.). Una taxonomía similar es la que propone el naturalista sueco Carl Linnaeus (1707-1778), quien postula que, además de esas cuatro categorías existe una cuarta raza de seres humanos salvajes, monstruosos y subhumanos. ${ }^{14}$ Asimismo, el filósofo alemán Immanuel Kant (1724-1804) se apoya en las teorías hipocrático-galenas de los temperamentos y en las ideas biológicas de Buffon, llegando a la conclusión de que existen cuatro razas: los nobles rubios del norte de Europa, los cobrizos de América, los amarillos de la zona indo-asiática, y en último lugar, los negros subsaharianos (Ward n.p.). Como monogenista partidario de la teoría de la

\footnotetext{
${ }^{13}$ Otro naturalista y físico partidario del monogenismo y la "hipótesis degenerativa" es el alemán Johann Blumenbach (1752-1840), quien afirma que el ser humano proviene de unos Adán y Eva caucásicos, y que ciertas razas cambian con el tiempo por la influencia medioambiental (Ward n.p.).

${ }^{14}$ Las cuatro divisiones de Linnaeus están basadas en el continente de origen de cada grupo y el color de su piel, a los que se añaden una serie de rasgos estereotípicos basados en los temperamentos clásicos (Ward n.p.). Asimismo, el naturalista pasa a la historia por su taxonomía jerárquica de los organismos vivos que incluye a los hombres dentro del grupo de los primates (la categoría Anthropomorpha) (n.p.).
} 
degeneración, Kant creía que la influencia medioambiental originó un cambio biológico, hereditario y, finalmente, inalterable (n.p.). ${ }^{15}$

En 1859, aparece un estudio revolucionario que da un giro sin precedente a la manera de entender al ser humano y su entorno; se trata de la obra canónica de Charles Darwin (1809-1882), El origen de las especies. ${ }^{16}$ A partir de este momento, el interés por la ciencia y la "razón" en boga durante la Ilustración se mezcla con la fascinación por la tecnología y la industrialización decimonónicas. De este modo, se afianza la vocación por el método empírico y las categorizaciones científicas de todos los aspectos de la vida natural y humana. Ejemplo de ello son los viajes de exploración que -ya florecientes en la era de los descubrimientos (XV-XVII) cuando los europeos empiezan a cartografiar el planeta- toman un matiz científico en entre los siglos XVIII y XIX. En este periodo, los europeos ya no pretenden descubrir nuevas tierras, sino observar las regiones del mundo y catalogar su orografía, clima, flora, fauna e incluso sus habitantes. Sin embargo, sobre todo en el caso de las Colonias, el objetivo secundario de los viajes de exploración es el

\footnotetext{
${ }^{15}$ De manera análoga, el filósofo alemán Georg Hegel (1770-1831) afirma que existen unas cuatro o cinco razas separadas (al margen de su origen común o independiente) con rasgos específicos y lideradas por la blanca (Moyar 503). Otros pensadores y científicos destacados de los siglos XVIII y XIX que teorizan sobre las categorizaciones humanas son John Hunter (1728-1793), Charles White (1728-1813), Cornelius de Pauw (1739-1799), Benjamin Rush (1746-1745), Christoph Meiners (1747-1810), Samuel Stanhope Smith (1751-1819), Georges Cuvier (1769-1832), Arthur Schopenhauer (1788-1860), Auguste Comte (1798-1857), Franz Ignaz Pruner (1808-1882), Karl Vogt (1817-1895), Ernst Haeckel (1834-1919), Herbert Hope Risley (1851-1911).

${ }^{16}$ Otro pensador que defiende la existencia de la influencia del medio sobre el ser humano es Jean-Baptiste Lamarck (1744-1829), quien sostiene que los seres vivos se adaptan a las circunstancias que los rodean y, con el tiempo, van afectando a su progenie y su comportamiento (una teoría posteriormente llamada lamarckismo): "Nature, in producing successively all the species of animals, beginning with the most imperfect or most simple in order to end her work with the most perfect, has gradually made their organization more complex; and with these animals spreading generally throughout all the habitable regions of the globe, each species received from the influence of the circumstances in which it is found the habits now recognized in it and the modifications of its parts that observation shows to us..." (Burkhardt $150)$.
} 
de afianzar el dominio europeo sobre las tierras exploradas. Las divisiones sociales, ya presentes en épocas anteriores, empiezan a apoyarse en los métodos pseudocientíficos decimonónicos, con el fin de consolidar las jerarquías sociales y de poder. Las teorías de Darwin son utilizadas para tipificar los sexos, nacionalidades, religiones y etnias humanas, dejando poco o ningún espacio para la transgresión y la movilidad social. Surgen tendencias como el "racismo científico" y sus conjeturas sobre las divisiones entre razas "superiores" e "inferiores", o el "darwinismo social", que defiende el hecho de que la selección natural y la competencia entre etnias, naciones, o clases, revelarán la superioridad de ciertas comunidades frente a otras. Entre otros estudiosos que contribuyen de manera directa o indirecta en este tipo de discursos destacan Francis Galton (1822-1911), primo de Charles Darwin, quien populariza el término "eugenesia"

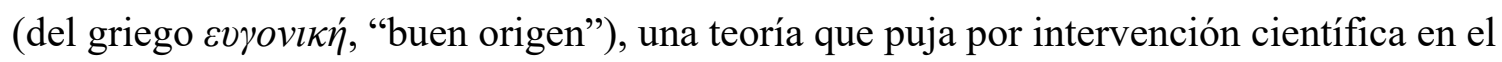
perfeccionamiento de los rasgos hereditarios (Revelle 3); y Herbert Spencer (1820-903), quien popularizó el concepto de "supervivencia del más apto".

Las nuevas taxonomías, por lo tanto, no sólo clasifican las idiosincrasias humanas, como ocurría anteriormente, sino que pretenden catalogar distintos "tipos" de seres humanos dentro de categorías "naturales" determinadas e inflexibles. En su libro Ensayo sobre la desigualdad de las razas humanas (1848) Arthur de Gobineau (18161882) propugna la superioridad de la "raza aria", los efectos nocivos de las mezclas raciales, y la importancia de la cultura, el medioambiente, y la alimentación para 
determinar la superioridad o inferioridad de las etnias (Gobineau 205-12). ${ }^{17}$ Gobineau opinaba que las mujeres asiáticas y subsaharianas tenían un fuerte poder de seducción sobre los hombres blancos, "amenazando" la raza aria con la hibridez y la degeneración (Young, Colonial 101). En su obra también se insiste en el hecho de que la superioridad de la aristocracia se debe a que esta ostenta una mayor cantidad de rasgos arios, por lo que está destinada a dominar al estado llano, que los posee en menor medida (Gobineau 212). ${ }^{18}$

Entre los estudiosos decimonónicos destaca Alexander von Humboldt (17691859), quien hizo un censo de la Nueva España, agrupando sus habitantes según su raza, características sociales y zonas de residencia, centrándose en la idea de que el medioambiente tiene un rol esencial en la formación del carácter y el aspecto físico del ser humano (Dassow 6). Otro autor que defiende la relación entre las circunstancias “naturales” y el comportamiento humano es Franz Joseph Gall (1758-1828), quien populariza la frenología, una pseudociencia que correlaciona las características del cráneo humano con su personalidad (Simpson, "Phrenology” 475). Más tardes estas teorías son utilizadas como base para explicar la "inferioridad" o "superioridad" entre razas y sexos, como en el caso de las teorías de Gustave Le Bon (1841-1931), inventor del "cefalómetro", utilizado con la intención de establecer un paralelismo entre la capacidad

\footnotetext{
${ }^{17}$ El termino, "ario/a" halla su origen en la palabra usada por los iraníes para autodefinirse y designar su país, Irán (Asgharzadeh 79). La palabra ha sido empleada, entre otros, por Adolf Hitler para argumentar la superioridad de los pueblos europeos (sobre todo los del norte).

${ }^{18}$ Lord Kames (1696-1782) era un filósofo poligenista, convencido de la existencia de cinco "especies" especies separadas, dominadas por la blanca (Cullis n.p.). Asimismo, afirma que existe una relación entre clima y raza, por lo que la naturaleza, guiada por la providencia, es responsable del progreso de ciertos grupos humanos (n.p.). La relación entre raza y clima también es apoyada por el botanista y físico norteamericano John Mitchell (1711-68).
} 
craneal y la inteligencia (Bon 1; Carson 102). La idea de que la inteligencia forma parte de la "naturaleza" de un individuo se sugiere en la tradición de Palma "El alma de Tuturuto" (cuarta serie), donde describe a los habitantes de Ecuador como "indolentes", indicando que la "inteligencia de los hombres es generalmente menos clara que la del bello sexo" (192-93) (ver Capítulo 3).

Finalmente, el médico y criminólogo italiano Cesare Lombroso (1835-1909) afirma que ciertas conductas humanas son producto de la herencia. Mediante su teoría sobre el atavismo criminal, relacionada con el determinismo biológico, declara que aspectos como la falta de agudeza mental o la tendencia a cometer actos criminales son identificables mediante el reconocimiento de rasgos (o defectos) físicos (Lombroso, Man 144). Con esta teoría, Lombroso sugiere además que los defectos en la forma del cráneo pueden relacionarse con las "razas inferiores" y que el cráneo y el cerebro de la mujer son más pequeños en comparación con el del hombre, asociándola con una fisionomía infantil y una inteligencia limitada (Man 9; Criminal 48-50). Por otra parte, sostiene que esto último no ocurre entre las "razas no civilizadas" como la subsahariana, en las que el peso y el tamaño de los cráneos de hombres y mujeres son similares (Criminal 50). De este modo, el criminólogo "masculiniza" a la mujer africana, descrita como un ser bárbaro y cuasi monstruoso. Tales comparaciones son propiciadas por el auge de la biología, ya que a menudo se hacen "analogías entre la especie animal y el comportamiento humano... por ejemplo, cuando los médicos comparan a las mujeres con las hembras de distintas especies animales... especialmente en los casos de la sexualidad femenina" (Mannarelli, Limpias 46). Finalmente, Lombroso argumenta que las clases sociales bajas, los epilépticos, los enfermos mentales, y los criminales, entre otros, son individuos inferiores 
que sufren una regresión hacia lo animal, asemejándose a los primates (Man 354, 35758). ${ }^{19}$

Según Carlos López-Beltrán, en el contexto latinoamericano decimonónico se da gran importancia a las ideas científicas y médicas de las elites europeas (302). Se insiste en los conceptos de "cuerpo social” y "cuerpo físico" o fisiológico, definido por "el color de la piel y el humor temperamental" (302). Estas teorías influencian a escritores y políticos peruanos de postura racista como Felipe Pardo y Aliaga (1806-1868) y Federico Elguera (1860-1928). Criado en Europa, Elguera escribe el artículo de costumbres "Las razas" (en El barón de Keef en Lima), tras trasladarse al Perú, en el que afirma: "antes de pisar la América, creía con Darwin, que el hombre descendía del mono; pero desde que subí a los tranvías de Lima, sostengo la teoría inversa" (84). Con este alegato, el autor corrobora la inclinación hacia el método científico de corte darwinista del periodo y su uso para reforzar los discursos xenófobos decimonónicos. En su obra aflora el miedo al hibridismo y asocia a los subalternos con el bestialismo, opinando que ciertos limeños esconden una "cola simiesca" bajo su atuendo, producto de la "mezcla infinita de sus castas” (Elguera 83; Velázquez, Mirada 271-72). De corte similar es Clemente Palma (hijo de Ricardo Palma), quien, en su tesis doctoral El porvenir de las razas en el Perú

\footnotetext{
${ }^{19}$ Con una ideología similar sobre el determinismo biológico o medioambiental, destacan Hippolyte Adolphe Taine (1828-1893) quien proclama la influencia de la raza y el medio sobre el individuo; y Claude Bernard (1813-1878) y sus estudios sobre la herencia. Taine y Bernard influencian, a su vez, autores como Émile Zola (1840-1902), padre del Naturalismo francés, quien pretende crear una novela "fisiológica" y defiende los efectos de la herencia en el comportamiento humano. Otro filósofo francés, Ernest Renan (1823-1892), destaca por sus estudios de las lenguas semíticas y su polémico antisemitismo que aflora en su obra Anticristo (1873). Asimismo, en La Reforme Intellectuelle et Morale (1871), Renan afirmaba que los rasgos raciales y culturales son determinados y que la naturaleza dictamina el papel de cada raza en la sociedad, por lo que estas no deben tener aspiraciones de movilidad social (93-94). Para él, los chinos son una raza apta para la artesanía, los negros son adecuados para el trabajo agrícola, mientras que los europeos pertenecen a una raza de líderes y de guerreros, por lo que su rol es el de controlar a las demás (93-94).
} 
(1897), hace una clasificación y análisis racista de las distintas etnias peruanas, subrayando la idea de que existen etnias superiores e inferiores, y que estas últimas impiden que las naciones avancen (Oliart 264). Asimismo, Alejandro Deústua Escarza (1849-1945) fue un pensador y diplomático peruano que acomete contra las comunidades indígenas, indicando que todo intento de educarlas resultaría fútil debido a su "inferioridad" (Villari y Leonel 133). Finalmente, el historiador peruano Javier Prado y Ugarteche (1871-1921) se hace eco del racismo científico, señalando "la influencia perniciosa que las razas inferiores han ejercitado en el Perú" (Klaiber 34).

En conclusión, cabe recordar las palabas de Christian Delacampagne en Racismo y Occidente (1983), quien indica que el término "raza" es utilizado con el fin de hilar un vínculo biológico imaginario dentro de un grupo que carece de tal unidad (218). Puesto que el ser humano no se categoriza mediante rasgos como su estatura, el tono de su cabello o su piel, la clasificación de su fenotipo carece de toda coherencia. Al igual que con las "razas", el sistema taxonómico se aplica al sexo, la nacionalidad, la cultura o la clase social, normalizando la marginalización y facilitando la interiorización del “orden estamental" como un hecho "natural" (Romero Meza n.p.). La solución, según Guillermo Rochabrún, reside en la eliminación completa del concepto de "raza", sustituyéndolo por el de "discriminación", puesto que la estigmatización de estos grupos carece de justificación científica o biológica (Rochabrún 24-25). De manera más drástica, podemos aplicar el mismo proceso a los conceptos de "género", "inclinación sexual”, o "etnia”, entre otros, puesto que se trata de términos artificiales utilizados para agrupar estos colectivos, "describirlos" y justificar su estigmatización y subordinación. 
3. Otros internos y externos. Identidad y nación en los discursos decimonónicos

Los ideales que impulsan los movimientos emancipatorios peruanos de principios del siglo XIX, moldeados por discursos de tolerancia y unidad, tienen el propósito de distanciarse de las anticuadas e inflexibles estructuras sociales coloniales. Sin embargo, lejos de hacer una reivindicación real de la diversidad, el objetivo independentista es el de desplazar las autoridades coloniales y sus representantes (extranjeros o nacionales), a favor de unas nuevas élites republicanas, compuestas mayormente por criollos blancos, y, en cierta medida, por mestizos y mulatos burgueses e intelectuales. Entre sus filas, no hay cabida para las clases trabajadoras, formadas principalmente por afroperuanos e indígenas. Tras la Independencia, se hace además un esfuerzo consciente para alcanzar el ideal de "modernización" nacional, en el que, frecuentemente, se excluyen a las clases humildes, y los Otros "raciales", religiosos o de género, representantes de las antiguas costumbres coloniales, la superstición, el analfabetismo y el atraso. Sin embargo, en un país profundamente dividido entre extensas zonas rurales pobres y ciudades, en las que se concentra la riqueza y el poder nacional, el Perú republicano no se diferencia mucho de la Colonia, ya que el poder y el patrimonio siguen estando en mano de una minoría. En este contexto, la "civilización" limeña de la costa, se separa de la "barbarie" de las zonas rurales y la sierra andina, abogando por el control de la sociedad peruana por parte de una élite patriarcal, burguesa, intelectual y simbólicamente blanqueada, cuyos valores y posición son idealizados. $^{20}$

\footnotetext{
${ }^{20}$ Véase el artículo de Luz Ángela Martínez, "La espectacularización de la Colonia y fundación de la identidad republicana en las Tradiciones Peruanas de Ricardo Palma". Revista chilena de literatura $\mathrm{n}^{\circ} 63$, 2003, y la tesis de Alberto Chiri-Jaime, El imaginario nacional en "Las tradiciones peruanas" de Ricardo Palma (2012).
} 
La representación de la ciudad de Lima es fundamental en la obra de Ricardo Palma, en la que la ciudad costeña es convertida en una metonimia del Perú (Velázquez, "Cultura" 332). Asimismo, el autor se dirige a un público que pertenece a su misma clase social, una creciente burguesía peruana formada por un alto porcentaje de criollos, mestizos o mulatos. Aunque, en ocasiones se describe como "plebeyo", y nace en el seno de una familia modesta, Palma no es de clase social baja, logrando, a lo largo de su vida numerosos éxitos que le llevan a convertirse en un intelectual acomodado de renombre. En la tradición "Un litigio original" (primera serie), el autor enumera las casas de nobles que se encontraban en Lima en 1698, afirmando: “[a]unque me humille confesarme plebeyo debo declarar, a fuer de veraz cronista, que allí no hubo ningún Palma; pues si alguno de este apellido comía por aquel siglo pan en Lima, debió estar aquejado de dolor do muelas o de punzada en el hueso palomo" (n.p.). De este modo, el autor sugiere con humildad que es plebeyo, es decir, no es descendiente de nobles, y que sus antepasados fueron probablemente de clase modesta. ${ }^{21}$ Asimismo, como se ha mencionado anteriormente, la identidad étnica del autor es difícil de identificar, puesto que, a pesar de que parte de sus antepasados pudieron ser blancos de origen europeo, Palma tiene ascendencia "parda", mezcla de indígenas, blancos y afroperuanos. El autor también puede considerarse un criollo peruano, una condición que no se asocia con una categoría biológica concreta, sino más bien con un estado social y legal que ocasiona la creación de una identidad que se separa de la de los descendientes europeos (Mazzotti 11-13). Por consiguiente, en su trabajo se vislumbra una clara intención de defender su posición

\footnotetext{
${ }^{21}$ Véase el artículo de Teodoro Hampe Martínez, "Las Tradiciones peruanas y el imaginario de la nobleza titulada del virreinato" (2001).
} 
social, afincada en la pequeña burguesía criolla, pero esta labor requiere el desplazamiento de otros colectivos, como son las clases humildes, los afroperuanos y los nativos, pero también los blancos, especialmente españoles, representantes del antiguo orden colonial. Tal como afirman George Umphrey y Carlos García-Prada, la vida y estilo literario del mismo Palma son muestras del cambiante entorno en el que vive el escritor:

Ricardo Palma era un mestizo representativo del siglo diecinueve, vale decir, un americano nuevo, inestable, en vía de formación: un espíritu sin orientación clara, precisa, definida, que se hallaba atraído por valores y realidades opuestas de fuerza para él irresistible: un espíritu en busca de su propio equilibrio. Esto lo vemos en su carácter, en su vida, en sus escritos. Quería una síntesis que no comprendía bien, y que en él actuaba de continuo. Era americano y procedía del pueblo, pero se doblegaba ante el prestigio de la aristocracia española, peninsular o americana. Se intitulaba 'liberal' y hacía campañas anticlericales, pero lisonjeaba a las clases conservadoras, y simpatizaba aún con los carlistas de España; se condolía de los pobres y de los humildes, pero pelechaba con los poderosos y se enorgullecía de los honores que le conferían a cambio de sus zalemas literarias; amaba el orden, la limpieza y el primor, pero se 'perecía' por lo abigarrado y por lo sucio si le parecían pintorescos y divertidos; cultivaba el idioma con esmeros de académico, pero lo 'matizaba' de vulgarismos, si ello le daba sabor a sus travesuras y picardías. (xxvi) 
Críticos como Oswaldo Holguín Callo, Víctor Andrés Belaunde y Carlos Pérez Garay afirman que en la obra de Palma se refleja la inestabilidad política que marca la Republica Peruana durante el primer siglo de su existencia (Pérez Garay 25). El activismo político de Palma se materializa en su labor literaria y periodística, y en su breve carrera política en el ejército, en el Senado y como Secretario de la Presidencia de José Balta, siendo unas de sus consecuencias su arresto y su exilio a Chile entre 1860 y $1863(26,33)$. El autor es un reconocido liberal democrático, que se opone el autoritarismo, el militarismo, y el clericalismo, aferrándose a las ideologías republicanas, institucionalistas, presidencialistas y masonas $(25,31)$. En sus orígenes, el movimiento liberal europeo decimonónico, propugna las ideas de la creciente burguesía como la igualdad social, el sufragio popular, la educación pública y la abolición de la esclavitud (44). Sin embargo, en el Perú se convierte en un movimiento más intelectual que pragmático, centrándose en lo ético, lo "romántico" y en la defensa de los ideales republicanos como "la igualdad ante la ley" y "la abolición de las costumbres coloniales" (45). Palma es además un escritor romántico que forma parte de lo que él llama la "bohemia limeña", por lo que se inspira en el sentimentalismo, el patriotismo, el heroísmo, y la tradición, convirtiéndose en leal "defensor de las libertades individuales, de la democracia, de la moralización y el progreso en el país" $(25,44) .{ }^{22}$

Sin embargo, con el tiempo Palma se distancia de parte de los preceptos liberales, inclinándose hacia ideas conservadoras y tradicionalistas, y promulgando una sociedad “ordenada", controlada por las autoridades (Pérez Garay 25, 27-28). Según Pérez Garay,

\footnotetext{
${ }^{22}$ Palma forma parte de un grupo literario juvenil entre 1848 y 1860, que Palma bautiza con el nombre de "bohemia limeña" (Pérez Garay 44).
} 
este cambio se debe a la fractura dentro de la ideología liberal "bohemia" en dos grupos (72). El primero, formado por liberales de ideología social y humanitaria, hace hincapié en activismo a favor de la igualdad social y, entre otras cuestiones, en la abolición de la esclavitud (72). El segundo, al que pertenece Palma, está integrado por liberales conservadores criollos, una élite intelectual que promulga la necesidad de igualdad y libertad dentro de un "orden" social y no se opone categóricamente al militarismo (7374). Palma escribe unos versos en su obra teatral Rodil (estrenada en 1852) en contra de la “ley de represión”, en la que expresa su talante patriótico, antimonárquico y de defensa de la igualdad social (76-77):

...esos nobles...

mientras el pueblo devora

su angustia desgarradora

gozan en lúbrica orgía... (Palma, Rodil 3-4)

No habrá nobles en la grey

seremos republicanos

serán todos los peruanos

iguales ante la ley. (51)

Por otro lado, especialmente a medida en que avanzan los años, Palma no comparte del todo el principio de igualdad (Pérez Garay 28). Entre 1845 y 1851, el gobierno del presidente Ramón Castilla (1797-1867), hace hincapié en la mejora del 
sistema educativo peruano, con el propósito de formar una elite burguesa e intelectual que tendría la misión de dirigir el país (49). Palma se beneficia de este renacimiento educativo, formándose en el centro de estudio más prestigioso de Lima, el Convictorio de San Carlos, en el que, sin dejar su afiliación liberal, se acerca a ideas conservadoras (50, 54). Destaca la influencia del director del Convictorio, el sacerdote Bartolomé Herrera, defensor de la teoría conocida como la "soberanía de la inteligencia", según la cual el pueblo es incapaz de gobernar, por lo que necesita de una elite intelectual que lo dirija (54). Para Herrera, "los individuos son desiguales", puesto que "unos tienen más capacidades que otros, y son esos más dotados por la naturaleza -por Dios en última instancia- quienes tienen el derecho de gobernar” (54). Según Carlos Pérez Garay, aunque Palma cuestionó el "carácter antidemocrático" de estas teorías, terminó aceptando "la idea de la superioridad de los individuos más inteligentes... destinados a mandar y dirigir la sociedad" (55). Palma recuerda las enseñanzas de Herrera del siguiente modo:

Por los años de 1850 se enseñaba, en San Carlos, la doctrina de la soberanía de la inteligencia; y aunque, por entonces, era muy prestigioso el acatamiento al principio de autoridad, como que todavía estábamos vecinos á los días del magister dixit, hubo lujo de tolerancia con la juventud que defendía el principio de la soberanía popular. (Palma, Cachivaches 107)

De este modo, Palma parece acercarse a la idea de que existen personas destinadas a pertenecer a la élite gubernamental y, por lo tanto, justifica su mejor condición económica y acceso a la educación. El destino de las personas con 
“inteligencias inferiores" es el de conformarse con posiciones sociales más bajas, un nivel económico inferior y menores derechos educativos. Para este colectivo, la movilización social es limitada, y no se considera el rol fundamental del contexto social y el privilegio en el desarrollo intelectual. Estas ideas se ajustan a las teorías deterministas que se gestan desde la antigüedad y son reforzadas mediante los postulados científicos del siglo XIX, abogando por la superioridad "innata" de ciertos individuos frente a otros (vean Capítulo 2). ${ }^{23}$

Esta austeridad ideológica se cristaliza con la admiración de Palma hacia el general Manuel Ignacio de Vivanco (1806-1873), gobernante del Perú en 1841 y entre 1843 a 1844, admirado por sus cualidades intelectuales y académicas (Pérez Garay 9495). Asimismo, el escritor se adhiere al gobierno conservador del presidente y general José Rufino Echenique (1808-1887) entre 1851 y 1855, durante el cual Palma se convierte en oficial $3^{\circ}$ del Cuerpo Político de la Armada (83). En la batalla de La Palma (1855), el ejército de Ramón Castilla derrota a Echenique, y Palma se queda en su puesto, pero más tardes apoya a la expedición revolucionaria vivanquista, por lo que es expulsado de la Armada en 1857 (89-90, 99).

El talante conservador del autor so observa ante su crítica hacia la "relajación de las costumbres" en su sociedad. Cuestiones como el adulterio, el amancebamiento, o la ilegitimidad son criticadas en su obra, haciendo hincapié en los excesos del clero en época colonial:

${ }^{23}$ Ladislao Graña (1817-1862), un español afincado en Jauja, en su tesis titulada Factores sociales de delincuencia en el Perú (1899), traza una separación entre clases, sugiriendo una afinidad entre tendencias criminales y ciertas razas (Aguirre, "Delito" 11). 
La simonía y todo género de excesos eran impunemente cometidos por el clero. El relajamiento de costumbres era tal, que bastara a pintarlo esta sencilla respuesta de un indio a quien la autoridad quería obligar a no vivir en mancebía, sino bajo la férrea coyunda matrimonial. «Taita -contestó el infeliz-, amancebamiento no puede ser malo, porque corregidor tiene manceba, alcabalero tiene manceba y cura tiene también manceba». (Tradiciones, "Pepe Bandos", segunda serie n.p.)

Según Palma, la "relajación de las costumbres" impera entre los grupos marginales, por lo que hace una neta distinción entre clases sociales. En “¡Pues bonita soy yo, la Castellanos!” (primera serie), el autor trata de manera muy distinta a dos mujeres de clase social diferente, dos notorias limeñas, amantes de prominentes figuras del gobierno y la aristocracia coloniales. La disputa, aderezada por la ostentación del lujo de las dos protagonistas, enfrenta a Mariquita Castellanos, la amada de un adinerado conde, y su némesis, Micaela (Mica) Villegas, llamada Perricholi, una plebeya y actriz de teatro, querida por un virrey. La Perricholi es un personaje basado en una figura legendaria de la cual no quedan retratos, pero es descrita por Palma como una "hembra de escasísima belleza", "manirrota" y "botarate" ("Pues bonita” 651). Mientras Mariquita y el conde representan la aristocracia o nobleza adinerada, Micaela representa a los plebeyos enriquecidos o nuevos ricos. Según Marcel Velázquez, la "tradición posee un claro carácter conservador ya que la plebeya andina [Micaela] que se atreve públicamente a demostrar un valer social más allá del que le correspondía es "puesta en su lugar" por Mariquita Castellanos que actúa como representante del orden social y garante de la 
hegemonía de la aristocracia sobre el pueblo" (Mirada 290). Asimismo, según Velázquez, cabe destacar la dimensión racial de esta tradición, en la que se hace hincapié en el hecho de que Mariquita es una bellísima morena, mientras que Micaela es de ascendencia andina, y, por lo tanto, aplaude a la afrodescendiente i condena a la indoperuana (290). Asimismo, Micaela, es castigada por la trama, ya que, debido a su falta de recato, se granjea la antipatía de la aristocracia y el pueblo. La protagonista es además criticada en "Genialidades de la 'Perricholi”" (cuarta serie), otra tradición en la que Palma afirma que su atractivo no reside en su belleza, sino en su magnetismo, que Micaela utiliza para cautivar a hombres "incautos" y evadir su posición social.

La actitud ambigua del escritor, quien, por un lado, aboga por dejar a un lado las anticuadas costumbres de la Colonia, y, por otro, pretende conservar una estructura hegemónica, es síntoma de la inestabilidad política del país y de una crisis identitaria nacional. Al mismo tiempo, demuestra que las diferencias entre clases siguen muy presentes, en una nación que aún conserva la ideología y la estética colonial (Valero 20). Podemos especular que las ambiguas actitudes hacia otras clases o etnias que asoman en la obra de Palma son el resultado de la negociación psicológica y social que muchos de sus contemporáneos hacen para encontrar su lugar dentro de la nueva distribución social. Este conflicto identitario parece alternar un rechazo y una aceptación hacia la diversidad, puesto que muchos peruanos de clase alta son o tienen antepasados mestizos, mulatos o pardos. Tal hipótesis podría corroborarse a la hora de analizar los relatos en los que aparecen individuos no pertenecientes a la burguesía criolla, observando en qué medida estos discursos afectan las identidades (nacionales) peruanas en una época en la que este sector aspira a obtener el reconocimiento social que se le había negado. En este contexto, 
el pueblo, o las clases sociales humildes, son un "Otro" nacional que debe ser controlado por las élites debido a su nominal "inteligencia limitada" y su bajo nivel educativo. Este talante se ve potenciado por factores como el analfabetismo del pueblo o el uso de variedades lingüísticas desvinculadas de lo que se considera la lengua "estándar" u “oficial” del Perú: el español.

\subsection{Lengua, escritura y educación}

En sus Tradiciones, Palma hace uso de un lenguaje colorido, mezclando harmoniosamente expresiones formales, el talante objetivo de un historiador, opiniones personales, ironías, y pasajes que retratan el lenguaje coloquial de Lima. Según Luis Chambilla, el papel de lo carnavalesco es fundamental en la obra palmina, y nos recuerda que, según Mijaíl Bajtín, este concepto se asocia con la cultura no oficial, distanciándose de la ideología dominante y burlándose de la rigidez de las estructuras e instituciones sociales (Chambilla 52). Este es precisamente uno de los objetivos principales de Palma, hacer una sátira de su sociedad y las instituciones de su país, apoyándose en la historia y costumbres nacionales. Sin embargo, su talante moralista hace que la descripción de las costumbres de minorías y subalternos se reduzca a una imagen estereotipada, minimizando su protagonismo y su papel en la construcción nacional.

La cuestión de la educación es central en la ideología independentista y republicana del siglo XIX. Se hace hincapié en la formación y el intelecto para que la nueva nación se acoja a la modernidad. Sin embargo, la postura de Palma es ambigua; por una parte, se muestra a favor de la educación para todos, quejándose, por ejemplo, del limitado acceso de las mujeres a la educación formal durante el virreinato: 
La educación de la mujer, en el siglo XVII, era tan desatendida que ni en la capital del virreinato abundaban las damas que hubiesen aprendido á leer correctamente correctamente; y aún á éstas no se las consentía más lectura que... [los] libros devotos, autorizados por el gobierno eclesiástico y por la Inquisición, enemiga acérrima de que la mujer adquiriese una ilustración que se consideraba como ajena á su sexo. (Cachivaches 95).

Por otra parte, en "El latín de una limeña" (tercera serie), Palma hace unas observaciones ambiguas sobre la educación de la mujer. En esta tradición, el autor critica el uso y la enseñanza del latín, como parte de un sistema educativo arcaico y pretencioso, utilizado en la Colonia. Asimismo, Palma menciona a las mujeres del pasado que se interesan con éxito en la lengua y la literatura latina, pero se centra en aquellas que fracasan en su cometido, como María Manuela Carrillo de Andrade y Sotomayor, quien “no sólo martirizó a las musas castellanas, sino a las latinas... las martirizó y sacó a vergüenza pública, porque... [sus] versos... son de lo malo lo mejor” (n.p.). Asimismo, menciona uno de sus personajes recurrentes, Mariquita Castellanos, descrita con una mezcla de admiración, por su belleza y donaire, y paternalismo, por su falta de formación:

Había a la sazón un poetastro, gran latinista, cuyo nombre no hace al cuento, a quien la Castellanos trata como un zarandillo prendido al faldellín. Habíala el galán ofrecido llevarla de regalo una saya de raso cuyo importe era de tres ojos de 
buey, vulgo onzas de oro. Pero estrella es de los poetas abundar en consonantes y no en dinero... Mariquita, recordando el latín que había oído al capellán de las clarisas, le contestó rápidamente:

-Tristis est anima mea, hasta que la saya vea.

El amartelado poeta, viendo que la muchacha ponía el dedo en la llaga, tuvo que formular esta excusa...

¿Et quare conturbas me, si sabes que no hay con qué?

A lo que la picaruela demoledora de corazones, mostrándole el camino de la puerta, le dijo:

-Entonces, fagite in allia, que otro gato dará algalia. (n.p.)

De este modo, Palma no solo hace hincapié en la naturaleza materialista de la limeña, sino también en su precaria educación, tan limitada que Mariquita la utiliza exclusivamente como arma para lucrarse u obtener algún tipo de beneficio. Según Marcel Velázquez, la "bella joven sin educación formal, pero con ingenio y gracia... utiliza un latín macarrónico que crea confusiones, pero finalmente, su ingenio y gracia se imponen al docto saber masculino" (Mirada 290-91).

El talante superficial de la mujer es descrito por críticos como Robin Lakoff, quienes argumentan que la mujer utiliza un lenguaje que denota "frivolidad" "susceptibilidad”, “debilidad” y “vacilación” (Selden 121). Sin embargo, los teóricos 
feministas subrayan el hecho de que la mujer en ocasiones utiliza este tipo de lenguaje porque ha sido víctima de sociedades patriarcales que les imponen una forma determinada de expresarse (121). Asimismo, es importante enfatizar el hecho de que el uso de un lenguaje que denota "sumisión" no es exclusivo de la mujer, sino de todo grupo social marginal o subalterno. En este contexto, se pueden citar las teorías de Michel Foucault, quien argumenta que el "discurso" es dominado por instituciones y élites, encargadas de nombrar a los portavoces de la "verdad", con el propósito de ejercer su poder sobre las minorías (Selden 147, 178). Por consiguiente, sólo un determinado modo de "hablar" y "escribir" son considerados "válidos" (147)

En la obra de Palma, también se hace hincapié en la forma de expresarse de las minorías étnicas. En sus Anales, el autor habla del "atraso y supersticiones dominantes en una raza [indígena] que está lejos de ser refractaria á la civilización y á la que, multiplicando las escuelas, es fácil apartar de torpes errores y de estravagantes costumbres tradicionales" (248). De este modo, afirma que los indígenas no son reacios a la educación, pero sugiere que sus costumbres son "inciviles" y deben ser rectificadas por las instituciones ante su aparente incapacidad de "progresar" de manera independiente. Según el autor, la cultura de las minorías está fuertemente anclada en las tradiciones y se caracteriza por el atraso, haciendo hincapié en el concepto de desigualdad cognitiva entre (descendientes) europeos y habitantes del Nuevo Mundo que se divulga desde principios de la Colonia. Desde un punto de vista europeo, la incapacidad de comunicarse en las lenguas occidentales está íntimamente ligado con "culturas inferiores", caracterizadas por individuos de "inteligencia inferior", como es el caso de los afrodescendientes y los 
indígenas. Según Beatriz Pastor, esta actitud nace entre los primeros colonos, como Cristóbal Colón, y empieza a difundirse en todo el mundo desde su desembarco:

Colón se concede, frente a los habitantes del Nuevo Mundo, el poder exclusivo de crear América, siguiendo las coordenadas establecidas por su modelo literario y presentando la ficción que resulta como fiel e incuestionable descripción de la realidad del Nuevo Mundo. Y el proceso de eliminación de la capacidad verbal de los indígenas que se da en el contexto del discurso colombino implica la eliminación de cualquier forma de pluralidad cultural. Del mismo modo que una lengua -la hablada por Colón- se convierte dentro de ese discurso en la Lengua frente al mutismo impuesto por el narrador a los nativos, la cultura occidental que el Almirante representa se presentará como la [verdadera y única] Cultura frente a un implícito vacío cultural indígena. Colón habla la Lengua y representa la Cultura, por ello es el que conceptualiza, formula y define Lengua, Cultura y Hombre. (Pastor 44)

En este pasaje, Pastor sugiere que la "eliminación de la capacidad verbal de los indígenas" es un instrumento de control por parte del colono, puesto que la incapacidad de comunicarse de manera efectiva en español se interpreta como una carencia absoluta de dotes comunicativas. Recordemos que el Perú cuenta con una amplia variedad de idiomas como el quechua, el aymara, el jaqaru y el kawki, así como numerosas lenguas en la región amazónica, como el asháninka y el aguaruna. Sin embargo, en última instancia, el nominal "vacío cultural indígena" es el pretexto utilizado para los colonos 
para ejercer su poder sobre estos subalternos. La lengua se convierte, de este modo, en uno de los principales instrumentos de dominación, tal como indican, entre otros, Michel Foucault y Gayatri Spivak. Según Spivak, la lengua es utilizada como arma para marginar a los Otros a varios niveles, ya que estos colectivos son simultáneamente silenciados e incapacitados para auto-legitimarse, puesto que, de tener voz, dejarían de ser considerados subalternos (Selden 224). Por lo tanto, estos grupos no pueden ni ser amparados por las élites, ni defenderse por sí solos, anulando toda posibilidad de que existan discursos anticoloniales (224).

Las ideas coloniales sobre la falta de cultura y las aptitudes limitadas de los subalternos se refuerzan en el siglo XIX como resultado de la influencia del darwinismo social, cuyos argumentos (ampliamente refutados) postulan que los individuos son sujetos a la selección natural darwiniana y ciertas personas son más "aptas" que otras para la evolución y el progreso. Bajo los auspicios de esta corriente, pensadores europeos como los alemanes August Schleicher (1821-1868) y Ernst Haeckel (1834-1919), consideran que la lengua es el rasgo principal que distingue al ser humano de otras especies, y que las distintas lenguas del mundo han tenido un origen independiente, evolucionado en paralelo, en el seno de las "distintas razas" (Richards, "Linguistic Creation" 24, 26). ${ }^{24}$ En el contexto decimonónico, no es improbable que esas lenguas de "distinto origen" sean consideradas representativas de sociedades, clases sociales, etnias o incluso sexos distintos, contribuyendo al éxito de unos frente a otros. Tal como indican Julie Andresen y Phillip Carter, la lengua es símbolo de identidad, ideología y nación, es

\footnotetext{
${ }^{24}$ Asimismo, Ernest Renan (1823-1892), destaca por sus estudios de las lenguas semíticas y su polémico antisemitismo que aflora en su obra Anticristo (1873).
} 
el instrumento utilizado por los hablantes para "orientar" a otros hacia sus dominios socio-cognitivos (Languages 5). Es decir, los hablantes utilizan la lengua para atraer a aquellos individuos que pertenecen a sus mismos grupos lingüísticos, y, mediante la interacción, se crean las identidades personales (5). Al coincidir con hablantes de otras variantes lingüísticas, se activa un sentimiento de "contraste", que hace que unos individuos crean que sus "personalidades", o comportamientos, son distintos a los de otros (8). Según Andresen y Carter, la Revolución Francesa (1789-1799) fue crucial en la manera de entender la nación como una unidad, un "único pueblo" -cultural o étnicamente homogéneo- con una "única lengua", tal como se refleja en uno de sus lemas, une langue, une nation (una lengua, una nación) (72). Por consiguiente, el concepto de nación-estado, con un territorio delimitado y una lengua única, es relativamente reciente, gestándose durante Renacimiento y la Ilustración (71). Según Andresen y Carter, tras la Revolución Francesa, el valor simbólico de la lengua se vuelve tan arraigado que, por primera vez, se propaga un sentimiento denominado vergonha (un término utilizado por los occitanos del sur de Francia) (72). Se trata de un sentimiento de "vergüenza" entre hablantes de lenguas minoritarias que intentan preservar su herencia lingüística, y de un acto de "humillación" por parte de las culturas dominantes, que pretenden forzar su "ideal" lingüístico (72). Este sentimiento puede extrapolarse a otros países y periodos, como el Perú decimonónico, que pretende definirse como un estado autónomo con una identidad y unos rasgos propios.

La lengua también es utilizada como elemento de exclusión en los discursos contra los afrodescendientes, quienes son ridiculizados por su nominal "informalidad" y "lisura" (atrevimiento) a la hora de hablar. En "Con días y ollas venceremos" (segunda 
serie) se describe al mayordomo de Pizarro como "un negrito retinto, con toda la lisura criolla de los budingas y mataperros de Lima, gran decidor de desvergüenzas" (n.p., cursivas del original). La descripción del afroperuano hace hincapié en el color de su piel y en el hecho de que la "lisura" es propia de los "budingas", un eufemismo para señalar a los afroperuanos, y a los "mataperros", usado para designar a muchachos callejeros y traviesos (REAL ACADEMIA). Asimismo, en "Un litigio original" (primera serie), Palma narra la historia de un encuentro entre los carruajes de dos nobles, que convergen en un estrecho callejón. Incitados por sus amos, los esclavos cocheros emprenden una pugna de insultos con tal de no cederse el paso, enzarzándose en una discusión que enfatiza su lenguaje blasfemo y obsceno: “¡A la izquierda, negro bruto!’, ¡Déjame la derecha, negro chicharrón! (n.p.).

Además de su inadecuado uso de la lengua, a los subalternos también se le atribuye frecuentemente cierto rechazo hacia la escritura y un analfabetismo "incurable". Esta ideología ya estaba presente en discursos premodernos como los Comentarios Reales $(1609,1617)$ del cronista Inca Garcilaso de la Vega (1539-1616):

... un capataz español ... envió a su amo diez melones, que llevaron dos indios a cuestas, según la costumbre de ellos, con una carta. A la partida les dijo el capataz: "No comáis ningún melón de éstos, porque si lo coméis lo ha de decir esta carta". Ellos fueron su camino, y a media jornada se descargaron para descansar. El uno de ellos, movido de la golosina, dijo al otro: “¿No sabríamos a qué sabe esta fruta de la tierra de nuestro amo?” El otro dijo: “No, porque si comemos alguno, lo dirá esta carta, que así nos lo dijo el capataz”. Replicó el primero: "Buen remedio; echemos la 
carta detrás de aquel paredón, y como no nos vea comer, no podrá decir nada”. El compañero se satisfizo del consejo, y, poniéndolo por obra, comieron un melón. Los indios, en aquellos principios, como no sabían qué eran letras, entendían que las cartas que los españoles se escribían unos a otros eran como mensajeros que decían de palabra lo que el español les mandaba, y que eran como espías que también decían lo que veían por el camino; ... por encubrir un delito, hicieron otro mayor, que se comieron otro melón. Los ocho que llevaban presentaron a su amo; el cual, habiendo leido la carta, les dijo: “¿Qué son de dos melones que faltan aquí??” Ellos a una respondieron: "Señor, no nos dieron más de ocho”. Dijo Antonio Solar: “¿Por qué mentís vosotros, que esta carta dice que os dieron diez y que os comisteis los dos?" Los indios se hallaron perdidos de ver que tan al descubierto les hubiese dicho su amo lo que ellos habían hecho en secreto; y así, confusos y convencidos, no supieron contradecir a la verdad. Salieron diciendo que con mucha razón llamaban dioses a los españoles... (Inca Garcilaso, Comentarios 502)

La importancia de este pasaje reside en el hecho de que estas ideas tienen continuidad en épocas posteriores, como puede observarse en la tradición palmina "Carta canta" (tercera serie), basada en este fragmento de los Comentarios del Inca Garcilaso. En el texto de Palma, la descripción de los nativos americanos y su intelecto está cargada de ambigüedades. El autor describe a los indígenas de manera despectiva, burlándose de su supuesta tosquedad, y, al igual que en los Comentarios, estos también malinterpretan la función de las cartas, atribuyéndoles poderes sobrenaturales: "[1]a sencilla ignorancia de los indios atribuía a la escritura un prestigio diabólico y maravilloso. Creían, no que 
las letras eran signos convencionales, sino espíritus, que no sólo funcionaban como mensajeros, sino también como atalayas o espías" (Fiengo-Varn 120, 145). Según Aurora Fiengo-Varn, a medida en que los nativos se convierten en sujetos marginados en las esferas sociales, políticas y comunicativas, la cultura oral indígena choca tanto con la escritura como con los idiomas europeos (120).

A pesar de ser retratado como un colectivo inepto, cabe destacar que, aunque no conocían la escritura occidental, grupos de nativos como los incas disponían de un elaborado sistema de comunicación a través del quipu (o khipu en quechua). El quipu es un entramado de cuerdas con nudos dispuestos para formar significado, y los tocapus, unos textiles cuyos diseños geométricos correspondían con significados determinados (Burns Glynn 5; Silverman 444). Estos instrumentos son mencionados por Guamán Poma de Ayala, quien indica que "los indios no conocían letra ni escritura alguna, por cuyo motivo todo lo que está escrito en esta obra ha sido tomado de los quipus... Los escribanos asentaban todo en el quipu con tanta habilidad que las anotaciones resultaban en los cordeles como si se hubiera escrito con letras" (Burns Glynn 21). Estos testimonios corroboran, por lo tanto, que los indígenas no sólo tenían sus propias lenguas, sino también elaborados sistemas de comunicación gráfica, posibles gracias a sus admirables habilidades técnicas.

El rechazo de los nativos hacia la escritura, asociado con su nominal superstición, también afloran en "La sandalia de Santo Tomás" (cuarta serie):

En Calango, a diez y seis leguas de Lima y cerca de Mala, existe sobre una ladera una piedra blanca y muy lisa y bruñida... Nótase en ella, y hundida como en 
blanda cera, la huella de un pie de catorce puntos, y alrededor caracteres griegos y hebreos. El padre Calancha dice en su Crónica Agustina que en 1615 examinó él esta peña, y que diez años más tarde, el licenciado Duarte Fernández, recorriendo la diócesis por encargo del arzobispo don Gonzalo de Ocampo, mandó destruir los caracteres, porque los indios idólatras les daban significación diabólica. (n.p.)

En este pasaje se sugiere, no sólo que los indígenas de la Colonia son gobernados por las supersticiones, sino también se culpa a las instituciones católicas por fomentar este comportamiento y mantener a los indios en el obscurantismo.

A pesar de sus discursos ambiguos hacia las comunidades nativas y sus formas de expresarse, Palma es participe de la estigmatización lingüística que se ejerce en su país. El escritor parece abogar por el uso de la lengua española como idioma nacional, pero reivindica la importancia de términos peruanos, incluidos los que proceden de las lenguas nativas del país. Como director de la Real Academia Española de la Lengua en el Perú, el académico luchó para que ciertos neologismos y peruanismos fueran aceptados por la sede peninsular de esta institución, utilizando unos argumentos que defiende en sus libros Neologismos y americanismos (1896) y Papeletas lexicográficas (1903), entre otros. ${ }^{25}$ En Papeletas, el autor reivindica que:

\footnotetext{
${ }^{25}$ Otro texto primario en el que afloran cuestiones sobre la lengua peruana es el "Diccionario de peruanismos" de Juan de Arona. Véanse los trabajos de Mariela de la Torre, "Las ideas lingüísticas de Ricardo Palma en sus dos obras lexicográficas: Neologismos y americanismos y Papeletas lexicográficas". Boletín hispánico helvético, núm. 23, 2014, 165-93; César A. Ángeles Caballeros, "Los peruanismos en las Tradiciones en salsa verde"; Ana Peluffo. Lagrimas andinas; Flor María Rodríguez-Arenas, "El lenguaje coloquial y el humor en las Tradiciones en salsa verde de Ricardo Palma". Revista de la Casa Museo Ricardo Palma 2: 2 (jul. 2001): pp. 69-90; Isabelle Tauzin Castellanos, "Refranes y tradiciones en la obra de Ricardo Palma" (2003); Luz Ángela Martínez, "La espectacularización de la Colonia y fundación de la identidad republicana en las Tradiciones Peruanas de Ricardo Palma". Revista chilena de literatura, núm.
} 
Más que los doctos, de suyo engreídos y autoritarios, es el pueblo quien crea las palabras y el uso quien las generaliza... Mucha gracia me hace aquello de que, en un Diccionario, sólo deben estamparse las palabras de uso literario y culto, desdeñando las vulgares del pueblo... No tengo devoción por los escrúpulos de monja boba, ni acepto que un Diccionario se parangone con el manualito de Moral y Urbanidad... La división de las palabras en feas y bonitas, como algunos han escrito, me ha parecido siempre un grandísimo despapucho. No me explico el ideal de belleza tratándose de palabras" (Papeletas vi, cursiva del original).

De este modo, no sólo enfatiza el rol de los nuevos vocablos para dar amplitud y colorido a la lengua, sino también en el rol de las instituciones para mantener las desigualdades sociales. Asimismo, en una carta dirigida al poeta uruguayo Juan Zorrilla de San Martin, Palma se queja del siguiente modo:

la discusión el eterno tema del americanismo en literatura. Con lengua, religión, costumbres y hasta instituciones genuinamente españolas, con urdimbre que no es de nuestra propiedad esclusiva, mal podemos aspirar á una originalidad absoluta. Pero si por americanismo en literatura queremos significar lo especial del colorido para pintar fielmente la exuberancia vital de nuestra naturaleza, que en poco ó nada se asemeja á la de los viejos pueblos europeos y asiáticos; las aspiraciones de razas y sociedades 
nacientes, y las idealidades, no diré si patrióticas ó patrioteras, que nuestra condición democrática encarna, el problema queda resuelto, y á usted corresponde parte en la solución. (Cachivaches 129)

Sin embargo, sus ideas de inclusión y sus propuestas nunca fueron aceptadas por la sede peninsular.

El conflicto entre oralidad y escritura también es una cuestión fundamental en la formación ideológica decimonónica. La lengua hablada ha sido tradicionalmente subordinada a la escritura, considerada símbolo de intelectualidad. El analfabetismo, por lo tanto, es asociado con la "barbarie" y con los subalternos. Tal como indica Raquel Chang-Rodríguez en La Apropiación del Signo, el uso de la escritura (o el signo), era considerado aquello que caracterizaba una sociedad civilizada (25). De este modo, en el contexto colonial y postcolonial, España se distancia del Nuevo Mundo, convirtiendo la escritura y la lengua en instrumentos de dominación (25). Tales reflexiones se plasman en el trabajo de Palma, quien asimila la imagen devaluada que los habitantes de ultramar asignan a los Otros latinoamericanos.

Finalmente, en la obra de Palma la estigmatización lingüística no es exclusivamente dirigida hacia mujeres u Otros "raciales" y, a menudo, estos no son portadores de un único defecto, sino de múltiples lacras. En su obra se hacen repetidas y simultáneas asociaciones de los Otros con varios aspectos negativos relacionados, como el analfabetismo, la ignorancia, la superstición, el paganismo y la brujería. En la tradición "Matrícula de Colegio", el texto se burla de un humilde boticario italiano y su 
"macarrónica manera de escribir", cuando este dirige una carta al director de una escuela en la que pretende matricular a sus tres hijos (Tradiciones en salsa 65):

Signore, dom Pietro Cañafistola, directtore de la escuela municipale de Chumbivilcas, 3 de Aprile de 1890.

Mio diletto signore: Fa favore de matriculeare ne la sua escuela, mei figlici Benedetto, Bartolomeo e Cipriano, natti in questta citá de Cumbivilcas, il giorno 20 de Febraio de 1881.

Sono suo servitore e amico

Crispin Gatiessa

Aquí el autor hace una descripción estereotipada y desmedida de la forma de escribir del humilde italiano. Asimismo, como discutiré en el Capítulo 4, es interesante observar como en una única tradición se unen varios discursos de discriminación, como es el rechazo hacia las clases sociales humildes, la alteridad racial, la homosexualidad, y la educación dañina proporcionada a los niños por parte las madres. Asimismo, esta tradición nos lleva a la descripción del otro colectivo frecuentemente estigmatizado en los discursos decimonónicos: el de los "Otros extranjeros".

\subsection{Extranjeros y blancos en el Perú decimonónico}

La razón por la que el blanco inmigrante puede incluirse en una sección dedicada a "Otros internos y externos", se debe a que este colectivo no es discriminado en cuanto a su fenotipo, sino en consideración de otros factores, como su nacionalidad, su religión o 
su clase social. En la obra de Palma, no faltan referencias hacia estos Otros, presentando a tipos como el despótico colono español, el "gringo" estadounidense "borrachín", el "bachiche" italiano pobre, el avaricioso judío (portugués), el rudo gallego, o el frívolo y arruinado andaluz. En ocasiones, el objetivo de estos discursos no es únicamente el de subrayar la otredad de los extranjeros, sino de socavar la autoridad de los descendientes de los europeos, asociados con las antiguas Colonias. De este modo, se hace un intento, normalmente infructuoso, de reafirmar la posición de grupos sociales que en las Colonias se encontraban en una situación más desfavorecida, como es el caso de criollos, mestizos o mulatos. Bruno Lesevic señala que, en 1876, año en el que se realiza el primer censo moderno del Perú, la población de extranjeros se distribuía del siguiente modo (131):

\begin{tabular}{|c|c|c|}
\hline Procedencia & Número & Porcentaje \\
\hline Asiáticos & 49.979 & 50,6 \\
\hline Bolivianos & 12.321 & 12,5 \\
\hline Chilenos & 14.235 & 14,4 \\
\hline Italianos & 6.990 & 7,1 \\
\hline Ecuatorianos & 4.086 & 4,1 \\
\hline Españoles & 1.699 & 1,7 \\
\hline Ingleses & 3.379 & 3,4 \\
\hline Franceses & 2.647 & 2,7 \\
\hline Alemanes & 1.672 & 1,7 \\
\hline Otros & 1.699 & 1,7 \\
\hline
\end{tabular}




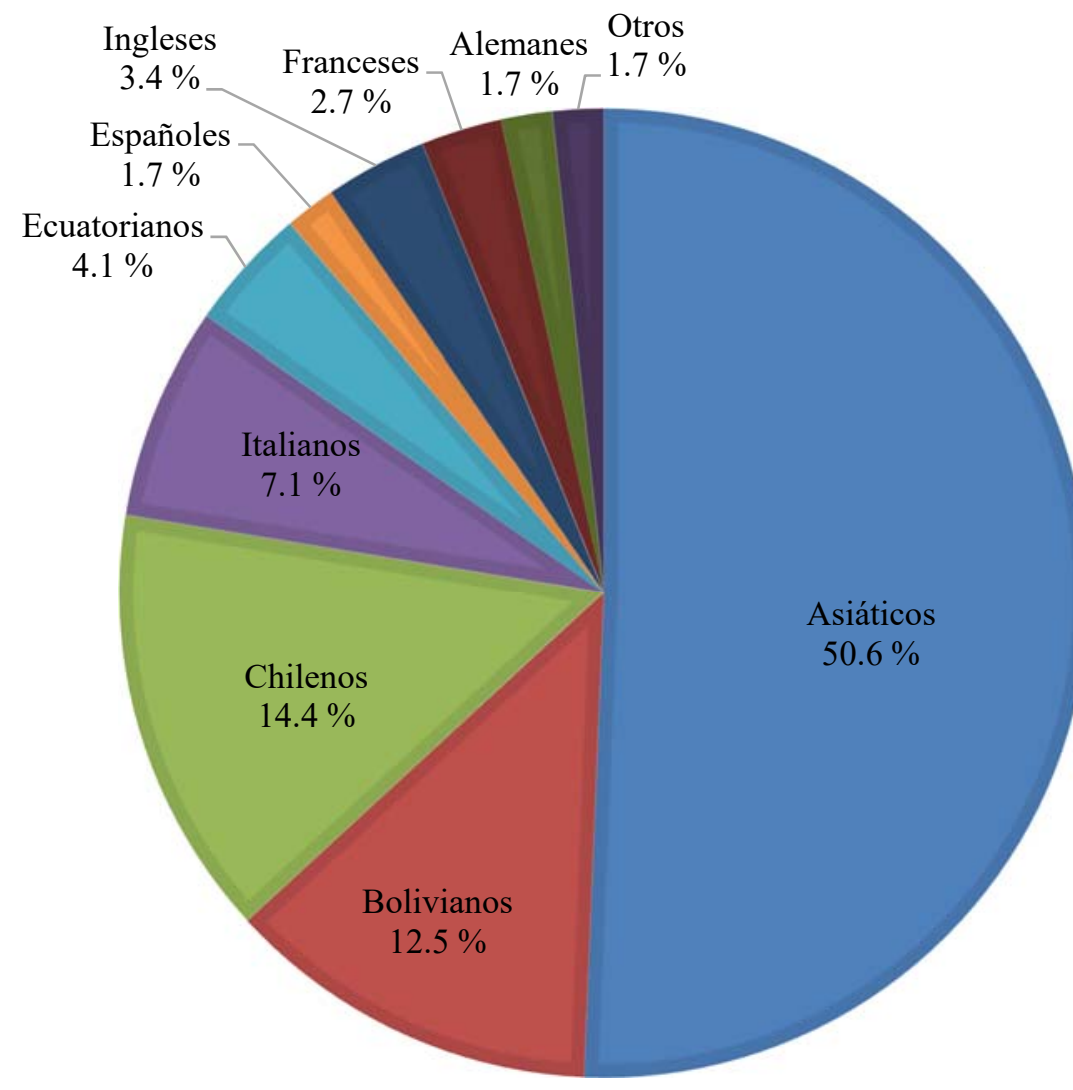

Total

98.707

100

Tabla 1. Número y porcentaje de extranjeros en el Perú según el censo de 1876 (Lesevic 131; Cosamalón 247).

Tabla 2. Porcentaje de extranjeros en el Perú según el censo de 1876 (Lesevic 131; Cosamalón 247).

Aunque según el censo de 1876 la proporción de asiáticos supone más de la mitad de los inmigrantes en el Perú en ese año, este grupo tiene escasa representación en la obra de Palma. Sin embargo, hay un gran número de referencias hacia españoles y extranjeros inmigrantes. Uno de los colectivos descritos de manera ambigua por Palma, es el de los 
italianos, o descendientes de italianos, en el Perú. Ejemplo de ello es la tradición "Traslado a Judas" (tercera serie), una historia que, según Palma, le contó su tía Catita sobre el joven hijo de un italiano. Haciendo una original mezcla de tópicos bíblicos y decimonónicos, el texto describe al muchacho subrayando su condición de "mataperros" (un chico callejero y violento), utilizando además el término "bachiche" para describir a su padre, un apelativo despectivo utilizado en Bolivia, Ecuador y Perú para designar al inmigrante italiano (pobre):

Mellado de un diente, bizco de mirada, narigudo como ave de rapiña y alicaído de orejas, era su merced feo hasta para feo. En la parroquia donde lo cristianaron púsole el cura Judas por nombre, correspondiéndole el apellido de Iscariote, que, si no estoy mal informada, hijo debió ser de algún bachiche pulpero.

Travieso salió el nene, y a los ocho años era el primer mataperros de su barrio. A esa edad ya tenía hecha su reputación como ladrón de gallinas. Aburrido con él su padre, que no era mal hombre, le echó una repasata y lo metió por castigo en un barco de guerra, como quien dice: «anda, mula, piérdete». El capitán del barco era un gringo borrachín, que le tomó cariño al pilluelo y lo hizo su pajecico de cámara. (n.p.; cursiva añadida)

En el pasaje, Palma describe de manera despectiva a al joven italo-peruano, una actitud negativa que expresa a la hora de describir a otros extranjeros blancos, como es el caso del "gringo borrachín". En las Tradiciones de Palma, no todos los italianos que se mencionan son pobres, aunque muchos de ellos tienden a asociarse con la inmoralidad y 
la criminalidad, un rasgo distintivo de José Boqui, el italiano quien protagoniza la tradición "La custodia de Boqui" (octava serie). En el relato, Palma narra la historia de este inmigrante que vive en el Perú entre 1810 y 1833 y se introduce en el gobierno del país hasta obtener el puesto de director de la casa de moneda. Sin embargo, cuando el italiano es puesto a cargo de transportar por barco un gran tesoro, éste zarpa y huye con el dinero. Palma concluye la tradición afirmando que el italiano, finalmente, "dirigió una mirada a la playa, e hizo un soberano corte de manga al Perú y a los cándidos peruanos" (n.p.). De este modo, el protagonista es inscrito dentro del imaginario del italiano traicionero, deshonrado y enemigo político de la patria.

El italiano es asociado con la criminalidad y la pobreza en otros discursos decimonónicos, como es el caso de la novela Herencia (1895), de Clorinda Matto de Turner, donde la autora describe a un bachiche italiano, Aquilino Merlo, un inmigrante sin educación que seduce a Camila, una bella joven de familia aristocrática venida a menos. Su encuentro sexual pone de manifiesto el recelo criollo hacia el inmigrante pobre mediante la deshumanización del italiano (Velázquez, Mirada 237-38). Marcel Velázquez sugiere que la atracción que sienten Aquilino y Camila se debe al determinismo que impulsa sus conductas: la ley de herencia de transmisión de sangre (237-38). Es decir, la joven tan sólo "repetía la trayectoria de la madre estimulada por el clima limeño", mientras que el italiano "formalizaba su carácter ancestral de ser instintivo y sin control, bárbaro bachiche" (237-38). De este modo, Matto se hace eco de las teorías deterministas decimonónicas (véase Capitulo 2).

En la obra palmina los (extranjeros) blancos son además caracterizados a menudo por su crueldad, avidez o malicia. En su tradición "San Antonio de Montesclaros" (cuarta 
serie) el autor habla sobre un español enviado por la corona española en el siglo XVII para administrar una mina, un hombre de "cáscara amarga y que por un pelillo mataba a palos a un indio como quien mata a un perro sarnoso" (218). Palma nos cuenta que, según el colono, "para los cholos no había cielo ni infierno, sino purgatorio eterno en esta vida y en la otra" (218). Aquí la descripción del nativo contrasta con la brutalidad del español, castigado por la trama puesto que la mina se derrumba y "una legión de diablos" se lleva su alma (219). En las descripciones de Palma, la violencia de los peninsulares no se limita a castigar los nativos, sino que arremete contra todo subalterno, como es el caso de las mujeres. En "El Cristo de la Agonía" (primera serie), el autor describe al célebre pintor de ascendencia española, Miguel de Santiago, quien, en el siglo XVII pinta un retrato, dejándolo al cuidado de su esposa. Sin embargo, el cuadro se ensucia y la mujer pide a Gorívar, discípulo del pintor, arreglar el desperfecto. Al darse cuenta de la alteración, Miguel monta en cólera, azotando al discípulo y cortando una oreja a su esposa. Sin embargo, la violencia de Miguel, no se limita a estos actos de crueldad, llegando a sus extremos cuando el pintor decide pintar a un "Cristo de la Agonía":

Entre los discípulos que frecuentaban el taller hallábase un joven de bellísima figura. Miguel creyó ver en él el modelo que necesitaba para llevar a cumplida realización su pensamiento. Hízolo desnudar, y colocolo en una cruz de madera. La actitud nada tenía de agradable ni de cómoda. Sin embargo, en el rostro del joven se dibujaba una ligera sonrisa... De repente Miguel de Santiago, con los ojos fuera de sus órbitas, erizado el cabello y lanzando una horrible imprecación, atravesó con una lanza el costado del mancebo. Éste arrojó un gemido y 
empezaron a reflejarse en su rostro las convulsiones de la agonía. Y Miguel de Santiago, en el delirio de la inspiración, con la locura fanática del arte, copiaba la mortal congoja... Por fin el gran artista desata a la víctima; vela ensangrentada y exánime... y como quien despierta de un sueño fatigoso, mide toda la enormidad de su crimen y, espantado de sí mismo, arroja la paleta y los pinceles, y huye precipitadamente del taller. ¡El arte lo había arrastrado al crimen! Pero su Cristo de la Agonía estaba terminado. (n.p.)

Como descendiente de españoles, el despiadado protagonista es retratado al igual que muchos personajes peninsulares, puesto que, aun siendo un blanco peruano, su crueldad, que roza la enajenación, es asociada con los españoles. El pintor ejecuta una violencia innecesaria que no duda utilizar contra los más débiles. Asimismo, el autor concluye haciendo un ulterior paralelismo entre Miguel y España, sugiriendo la decadencia de la Península: “[e]l cuadro fue llevado a España. ¿Existe aún, o se habrá perdido por la notable incuria peninsular? Lo ignoramos" (n.p.).

Otra tradición en la que surgen descripciones estereotipadas sobre los españoles es "La camisa de Margarita" (cuarta serie), protagonizada por la joven y rica limeña Margarita Pareja, quien se enamora de Luis Alcázar:

Llegó por entonces de España un arrogante mancebo, hijo de la coronada villa del oso y

del madroño, llamado D. Luis Alcázar. Tenía éste en Lima un tío solterón y acaudalado, 
aragonés rancio y linajudo, y que gastaba más orgullo que los hijos del rey Fruela.

Por supuesto que, mientras le llegaba la ocasión de heredar al tío, vivía nuestro D. Luis

tan pelado como una rata y pasando la pena negra. (n.p.)

Una vez más, el autor enfatiza varios aspectos que identifican al español como otro, ya que, además de ser un extranjero, es arrogante y, especialmente, pobre, por lo que el padre de Margarita rechaza al pretendiente de su hija: "[1]a negativa nacía de que D. Raimundo no quería ser suegro de un pobretón" (n.p.). Por consiguiente, el arrogante tío de Luis tampoco quiere consentir la unión. Con todo, Margarita y Luis consiguen casarse y obtienen un final feliz, porque, aunque el tío del joven no consiente que los enamorados obtengan dote alguna, Margarita recibe de su padre una costosísima camisa de novia que sustituye parte de la dote.

A pesar de estas descripciones negativas hacia los extranjeros blancos, considerados unos Otros externos, en los discursos decimonónicos, el color de la piel sigue siendo central para hacer una distinción de estatus social. La "sangre" blanca sigue considerándose beneficiosa para el desarrollo de las naciones latinoamericanas, tal como sugiere Clemente Palma: “¿Por qué la República Argentina y hasta Chile son hoy naciones florecientes? Por el carácter. ¿Y por qué tienen carácter? Por que los elementos inferiores de raza entraron en poca cantidad en la constitución de su pueblo actual, y los superiores en más cantidad: En oleadas benéficas ha recibido la República Argentina la sangre italiana, inglesa, francesa y española" (23). Por lo tanto, los europeos, o sus descendientes, pueden ser rechazados bien por su condición de extranjeros, bien por el 
hecho de ser "ex-conquistadores", o bien por ser pobres, pero nunca por su fenotipo. Sin embargo, para otros “enemigos nacionales” blancos, como los judíos, el elemento religioso es otro aspecto que entra en conflicto con las ideologías del Nuevo Mundo, por lo que su afiliación religiosa los convierte en Otros a pesar del color de su piel.

\subsection{Religión y otredad}

La religión es quizás uno de los atributos que más han sido utilizados para señalar la alteridad ajena. ${ }^{26}$ Aun sin estar en estrecha relación con otras características como la nacionalidad o el color de la piel, tales aspectos han sido tradicionalmente considerados inseparables con la religión, como es el caso de los musulmanes, tradicionalmente asociados con una tez oscura y con el Norte de África o el Oriente Medio. En otros casos, colectivos afiliados a una religión no cristiana, como es el caso de los nativos americanos, nunca son aceptados dentro de las naciones que los ven nacer. Las diferencias entre Otros religiosos y "raciales" han sido tradicionalmente desdibujadas (consciente o inconscientemente), ya que son representados en términos análogos. Tal como nos recuerda Hayden White en Tropics of Discourse (1978), desde un punto de vista externo, en ningún momento deja de estar clara la separación entre ciertas comunidades (165).

Desde una perspectiva occidental, se crean imágenes estereotipadas que aglutinan a colectivos muy diversos, como los de Asia, Oriente Medio, África o Latinoamérica. Asimismo, en ocasiones, sociedades tan apartadas como las subsaharianas y las nativas

\footnotetext{
${ }^{26}$ Véase Brian Bantum, Redeeming Mulatto. A Theology of Race, y Oswaldo Holguín Delgado, "Trazos para el perfil religioso de un liberal decimonónico (Ricardo Palma)". Revista de la Casa Museo Ricardo Palma, núm. 6, 2006, pp. 63-76.
} 
americanas son descritas con características religiosas, "raciales" o comportamentales muy similares. Un mismo discurso puede representar a estas sociedades como colectivos separados y, sin previo aviso, incluirlas en un mismo grupo. Tal aglutinación es igualmente presente en la representación de Otros nacionales, como las mujeres, quienes, como argumenta, entre otros, Julia Kristeva, aparecen en discursos desfavorables junto a Otros extranjeros, "raciales" y religiosos (181).

La discriminación religiosa es, en ocasiones, tan central como la exclusión étnica o "racial", y puede llevar a enfrentamientos extremos entre naciones, como es el caso de las guerras o las persecuciones religiosas, tanto en el Viejo como en el Nuevo Mundo. Tal como indica Eddy Romero:

El negro, zambo y mulato estará estigmatizado por el color de su piel, al igual que el indígena, aunque esencialmente serán discriminados por su cultura y religión.... La "idolatría" y "superstición" del indio y el negro fue la base de la discriminación española durante la etapa colonial. La extirpación de idolatrías... [y] los proyectos de castellanización a los indios... son algunos ejemplos de la censura o rechazo hacia la cultura de los pueblos dominados. (n.p.)

Por otra parte, no sólo las religiones no cristianas son objeto de crítica. Para Ricardo Palma, las instituciones religiosas son blanco de rechazo, puesto que el escritor está activamente en lucha contra tales organismos, especialmente cuando se trata de instituciones católicas. Este talante aflora en su Refutación a un compendio de historia del Perú (1886), escrito en contestación al texto escolar de historia del jesuita Ricardo 
Cappa, Historia compendiada del Perú, en el que el clérigo ataca al movimiento emancipatorio peruano (Armas 124). Como ferviente defensor de la Independencia, Palma arremete contra los jesuitas hasta el punto de que el Congreso peruano expulsa del país a dicha orden religiosa. Otro ejemplo de crítica hacia las instituciones eclesiásticas se halla en los Anales de la inquisición de Lima (1863), en los que Palma analiza documentos coloniales, como los autos de fe de la Inquisición limeña, conservados en la Biblioteca de Lima antes de su saqueo de 1881 en la Guerra del Pacífico (5-6). Con la ayuda de estos documentos, Palma analiza los actos de inquisidores y virreyes en la Colonia, así como las torturas sufridas por los condenados y las costumbres y supersticiones de los peruanos (5-6). Especialmente, Palma hace hincapié en el maltrato de los clérigos hacia los nativos durante la Colonia:

... los indios, en medio de sus infinitas supersticiones y prácticas gentílicas, son altamente fanáticos. No hacen diferencia entre Dios y el cura que los explota á su sabor... Hay pueblos en los que las novias, desde ocho días antes de contraer matrimonio, son depositadas en casa del cura, y á nadie escandaliza el que éste cobre el derecho de pernada... El despotismo de los curas para con la pobre raza indígena no tiene límites. (Anales 247).

Sin embargo, en su obra no faltan ejemplos de intolerancia hacia otras religiones, especialmente en lo que concierne a los indígenas y los judíos peruanos.

Tradicionalmente, las creencias de los subalternos son asociadas con el paganismo, es decir, un credo que no pertenece a las grandes religiones monoteístas, por lo que tanto los 
nativos, como los afroperuanos, e incluso los chinoperuanos, son distanciados de lo que se considera una "verdadera" religión:

La nación fundada por Manco-Capacc fué, por excelencia, supersticiosa. Vino la conquista, y con ella el cristianismo con su idolátrico culto de las imágenes, sus risibles milagros y su inmenso cortejo de supersticiones. Estas cayeron sobre terreno fértil, y la raza indígena aumentó con ellas el caudal propio... Los indígenas creen firmemente en los espíritus malignos. Las tempestades son producidas por un demonio... A él invocan los brujos para sus maleficios... Cuando un enfermo resiste á la eficacia de las yerbas medicinales, se apela á la ciencia de la bruja ó del brujo del lugar... encomendándose entre tanto la víctima á los santos de su devoción... (Anales 235-37).

Con estas palabras, el autor no sólo critica las creencias de los indígenas, sino que culpa a la religión católica, “con su idolátrico culto de las imágenes”, por propiciar la el desarrollo de una religión sincrética: "[unas] costumbres, en que andan mezcladas por igual las prácticas gentílicas y las cristianas” (Anales 246). Aunque Palma afirma que tales prácticas son castigadas por el clero, también asevera que existen "supersticiones que no sólo son propias de los indígenas, sino hasta de gente que pasa por civilizada" $(238) \cdot{ }^{27}$

\footnotetext{
${ }^{27}$ Véanse los artículos de Marco Martos Carrera, "Anales de la Inquisición de Lima: Ricardo Palma, La vela verde y el sambenito" (1998) y Teodoro Hempe Martínez, "Ricardo Palma, cronista de la Inquisición". 2004. Biblioteca Virtual Miguel de Cervantes, 2009.
} 
El paganismo es además asociado, bien con lo diabólico, bien con el rechazo hacia lo diabólico, en función de la ocasión y los discursos retóricos que sirven. En los Anales, Palma sostiene que:

Los indígenas creen firmemente en los espíritus malignos. Las tempestades son producidas por un demonio denominado Santiago, que, como el santo patrón de España, anda por los aires montado en caballo blanco, el que echa chispas de fuego. A él invocan los brujos para sus maleficios. En oposición al Santiago del mal, reconocen un Santiago del bien, protector de sementeras y ganados, al cual representan también á caballo, blandiendo un alfange como para ahuyentar á los espíritus dañinos. (236)

Según Robert Muchembled, desde la segunda mitad del siglo XIX, la idea de un Satanás castigador (ausente en la Biblia, pero muy presente en los discursos católicos) empieza a ser cuestionada, a favor de las nuevas corrientes científicas y filosóficas promulgadas a lo largo del siglo (Hurtado 84). Paulatinamente, se refuerza la idea de que el "viejo mito creado por la Iglesia [sobre Satanás]... conducía a la sumisión de las almas y al temor al cambio", por lo que "las imágenes diabólicas... estaban siendo integradas con las ideas de libertad y placer. Se retrataba a Satanás como el libertador de los pueblos, el progreso y la ciencia" (84). Si aplicamos estas ideas a la descripción de los nativos de Palma, podemos observar que, por un lado, la adoración de Satanás inscribe a los indígenas en el contexto de lo pagano, la herejía, y la inmoralidad. Por otro, cuando los nativos son representados como seres temerosos de la figura satánica, se les vincula 
con su rechazo hacia la modernidad y su facilidad de manipulación por parte de los católicos. De este modo, las instituciones eclesiásticas les infunden el temor hacia el ser demoniaco y la posibilidad de pérdida de su alma inmortal, con el propósito de mantener a los indígenas en el obscurantismo y continuar su labor de sumisión y explotación de estos subalternos. Esto corresponde además a la doble vertiente en la descripción del indígena como un bárbaro e inmoral "pagano", o como un "buen salvaje”, manso pero ingenuo y de fácil manipulación o adoctrinamiento. Otra tradición palmina en la que se asocia el paganismo con la figura de Satanás se titula "Los malditos" (segunda serie), un relato en el que el escritor representa un esclavo negro sacristán, sirviente de un clérigo, quien presencia despavorido un ritual andino en el siglo XVII:

El negro entró en San Pedro y pensó hallarse en una ciudad encantada. ... se encontró de pronto en una vasta sala donde se hallaba congregado todo el pueblo, en actitud de profunda veneración. En el centro de la sala alzábase un altar, y sobre él un ídolo representando una cabra. El cuerpo del animal era de plata, los cuernos, los pies y los pezones eran de oro, y los ojos lo formaban dos piedras negras como el ónice. Un indio, vestido con una túnica recamada de oro y plata, hacía las funciones de gran sacerdote, recitaba frases en tono de salmodia, y los adeptos, hombres y mujeres, por orden de antigüedad se acercaban al ídolo, ponían la boca en un pezón, y el gran sacerdote pronunciaba la palabra quichua ¡Hama!

Repuesto el pobre negro de la impresión terrorífica que le produjo el espectáculo de tan extravagante culto, pensó sólo en escapar del antro donde el 
azar lo había conducido... En materia de idolatría y superstición de los indios, podríamos escribir largo. (n.p.)

Tal como observa Marcel Velázquez, en esta tradición destaca la “incomunicación e incomprensión entre indios y negros”, y, mientras los primeros son asociados con la idolatría, los afroperuanos se caracterizan por su falta de protagonismo, ya que al ser "una extensión de la religión y cultura occidental (en este caso, del cura): su identidad se diluye" (Máscaras 171). Otra fugaz mención en la que asocian a los nativos con la idolatría aparece en "Las brujas de Ica” (sexta serie), en la que Palma menciona a D. Jerónimo Illescas "un brujo aristocrático" cuya fama como adivino "se había extendido de la ciudad al campo", por lo que las "indias, sobre todo, venían desde largas distancias y le pagaban un peso por consulta" (n.p.).

En ocasiones, los discursos decimonónicos no sólo asocian ciertos elementos religiosos con determinadas culturas o etnias, sino también varían dependiendo del género y la clase social, puesto que, a menudo, la superstición y la idolatría son asociadas con mujeres y las clases humildes. En la tradición "El alma de Tuturuto" (cuarta serie) confluyen comentarios sobe extranjeros y mujeres, relacionados bien con las supersticiones bien con la ignorancia. En ella Palma describe la ciudad ecuatoriana de Guayaquil en el siglo XVI como una ciudad en la que sus habitantes son "indolentes" y la "inteligencia de los hombres es generalmente menos clara que la del bello sexo" (19293). El autor sugiere, sin embargo, que la inteligencia femenina nace de su picardía, más que de su erudición, ya que la "coqueta" mujer "guayaquileña tiene la belleza del diablo" y en ella "hay mucho de la mujer de Oriente", asociando a este tipo de mujer con la 
seducción y la imagen del Oriente (193-94). Finalmente, la guayaquileña también es asociada con la frivolidad, la ignorancia y la superstición, ya que rechaza las matemáticas, símbolo de la ilustración, frente a los frívolos romances: "lo poético de su organización la hace creer en todo lo maravilloso y sobrenatural, como el espiritismo o las mesitas parlantes... como si estuviera leyéndoos un libro de Ana Radcliffe (193-94).

El orientalismo también está presente en la obra de Palma, mezclando la vertiente racial con la religiosa. Los orientales son asociados con todo tipo de discurso, como los es el caso de la anteriormente citada sensualidad de las mujeres levantinas. Los musulmanes protagonizan tradiciones como "El príncipe del Líbano" (quinta serie), en la que D. Elías Aben-Sedid, príncipe del Líbano, visita Lima en 1765 “cargado de títulos, cruces, condecoraciones y cintajos" (n.p.). Este personaje es retratado como "un turco de casi seis pies de altura, robusto y gallardo mozo, y que, a pesar de su nacionalidad, no profesaba la ley de Mahoma, sino la de Cristo" por lo que se mueve sin aprensión por la ciudad cristiana (n.p.) La tradición sigue narrando que el príncipe afirmaba que "el Gran Turco lo había despojado de sus Estados", tomando a sus hermanos como prisioneros y exigiendo "un rescate de cien mil pesos ensayados" (n.p.). ${ }^{28}$ Con sus relatos y su supuesto intento de rescate, el príncipe consigue obtener una gran suma de dinero de la población limeña y es acogido por la aristocracia y unos padres franciscanos. Sin embargo, pronto su "naturaleza" libertina sale a la luz: "acordándose de que era musulmán, se le despertó el apetito por las muchachas, enamorándose a la vez como lo que era, es decir, como un turco, de dos huríes limeñas y empeñando a ambas palabra de hacerlas princesas" (n.p.).

\footnotetext{
${ }^{28}$ La figura del "Gran Turco" es recurrente en la literatura occidental, representando a los sultanes otomanes, descritos como temibles figuras belicosas y despóticas.
} 
De este modo, el autor señala que el príncipe es bien un apóstata (o "falso converso"), bien un individuo que cambia de religión según sus intereses. Cuando se descubre el triángulo amoroso, una de las jóvenes se rebela y es apresada contra su voluntad por el príncipe, pero pronto se revela que se trata de un falso noble, se libera la joven y el impostor es desterrado a España. En esta tradición, se establece un claro paralelismo entre la religión islámica y la apostasía, es decir, la falsa conversión al catolicismo por interés. Su protagonista rápidamente vuelve a abrazar la religión musulmana cuando se propone cometer actos considerados depravados para los cristianos, como es el caso de la poligamia, ya que la religión islámica es descrita como una doctrina más permisiva con la inmoralidad. Afloran, asimismo, Palma hace referencia a la "limpieza de sangre", promulgada por los primeros colonos, una ideología con la que los peninsulares cristianos pretenden desvincularse de su pasado de convivencia con judíos y musulmanes. Si los españoles podían demostrar que no tenían antepasados pertenecientes a estas religiones, su sangre se consideraba "limpia". Tal empeño provocó que muchos peninsulares no cristianos se convirtieran al catolicismo, a menudo falsamente, por lo que detrás de un cristiano converso podía esconderse un "infiel”.

Otras fugaces menciones hacia los musulmanes y la religión islámica aparecen en “El capitán Zapata” (séptima serie), en la que Palma cuenta que en el siglo XVI, el español Don Rodrigo Peláez es apresado brevemente por los musulmanes en la costa española, y en "El encapuchado" (segunda serie), en la que uno de sus personajes se describe como un hombre que "tenía, entre otros mortalísimos pecados, los más arriba de la coronilla, ser celoso, como un musulmán y muy sentido en lo que atañe a la negra honrilla" (n.p.). Asimismo, en "Creo que hay infierno" (quinta serie), se describe un cura 
de San Juan de Lurigancho, a finales del siglo XVIII, retratado como un "religioso de la orden dominica y fanático como un musulmán” (n.p.). Por consiguiente, la religión islámica es imputada responsable por sus “influencias negativas” sobre los cristianos, como los celos, el fanatismo, la sensualidad y la promiscuidad. El oriente queda así asociado con las fantasías reprimidas de occidente, los sueños del serrallo y todo aquello que se prohíbe en occidente, como en la ya mencionada tradición "El alma de Tuturuto" (cuarta serie). Este relato es protagonizado por un pirata del siglo XVI llamado Tuturuto, cuya representación es asociada con la imagen del Medio Oriente: "Tuturuto tenía pretensiones de sultán. Si en la embarcación sorprendida encontraba mujeres jóvenes las hacía prisioneras, llevándolas al monte, donde las conservaba, haciendo las delicias de su serrallo, hasta que nuevas cautivas venían a reemplazarlas. Entonces las daba libertad o las cedía a los hombres de su banda" (n.p.). Con estas palabras, Palma parece crear un imaginario en el transporta el serrallo (o harén) asociado con el Oriente hacia tierras latinoamericanas, aunque el pirata es castigado por la trama, ya que "[u]na de las cautivas de Tuturuto, con humos de sultana favorita, le clavó un día tan soberbia puñalada en el corazón que lo dejó difunto” (n.p.). De este modo, no sólo se asocia al pirata con el Oriente, sino también a la mujer que se rebela y elude el cautiverio.

Además de los discursos sobre el Oriente Medio, en el siglo XIX también se dirige la mirada hacia Otros religiosos orientales como los chinos. En 1854, tras la abolición de la esclavitud en el Perú, crece el número de inmigrantes asiáticos utilizados como mano de obra barata, convirtiéndose en una etnia fuertemente discriminada en el 
país. Sin embargo, estos inmigrantes son casi ausentes en la obra palmina. ${ }^{29}$ Estos subalternos son, simultáneamente, unos Otros "raciales", foráneos y religiosos, despreciados por su nacionalidad, el color de su piel y por considerarse unos "paganos" politeístas. Una fugaz referencia a la religión china aflora en El Santo de Panchita (1859), una obra teatral que Palma escribe en colaboración con Manuel Ascencio Segura (vean Capítulo 6). En ella se describe brevemente a un anónimo conjunto de comerciantes chinos en Lima, y se especula sobre sus malévolas intenciones hacia los cristianos. Una de las protagonistas, Doña Feliciana, afirma que los chinos son cada vez más numerosos en el Perú, y se declara convencida de que estos envenenan el té que venden a los limeños, como, según ella, demuestra el alto número de muertos en la ciudad. Asimismo, Doña Feliciana describe a los chinos como una comunidad “excomulgada" que adora a Satanás, e incluso se ha atrevido a instalar "uno o dos templos" en la capital (344-45). De este modo, al ser un grupo probablemente politeísta, a los chinos se les acusa de venerar la figura demoniaca, definiendo su credo como una "no religión" o incluso un culto satánico.

Aunque los musulmanes, los habitantes de Oriente Medio o los asiáticos pueden considerarse, además de Otros "raciales", también unos rivales religiosos, Palma también describe a colectivos que no son discriminados por su etnia, centrándose principalmente en su "idolatría". Este es el caso de los judíos peruanos, que pueden considerarse como unos Otros religiosos y/o extranjeros, y son abundantemente presentes en la obra de

\footnotetext{
${ }^{29}$ Cabe destacar que, en Latinoamérica, en ocasión se utilizan los apelativos "chino" y "china” para designar a individuos indígenas o mulatos. Este apelativo aparece con frecuencia en la obra de Palma, poro no califica a individuos asiáticos.
} 
Palma (especialmente en sus relatos ambientados en el siglo XVII). Tal como afirma Edward Said en Orientalismo (1978), el antisemitismo y el orientalismo comparten raíces comunes (xviii). Por consiguiente, tanto en la obra de Palma como en otros discursos modernos, tanto musulmanes como judíos son acusados de apostasía, unos falsos conversos que deben ser "descubiertos" y condenados. Frente a la dificultad para distinguir a los judíos de los "cristianos viejos", es decir, aquellos que no tienen antepasados judíos, a menudo afloran elementos relacionados con el concepto español de "limpieza de sangre" española. Esto ocurre en "Los polvos de la condesa" (segunda serie), una tradición palima en la que se menciona la presencia de comerciantes judíos portugueses en Lima en el siglo XVII. El autor cuanta que, en esta época, "el conde de Chinchón”, uno de los virreyes del Perú, “fue tan fanático como cumplía a un cristiano viejo", por lo que decretó que “[n]ingún naviero podía recibir pasajeros a bordo, si previamente no exhibían una cédula de constancia de haber confesado y comulgado la víspera", para asegurarse de que estos no fueran judíos (n.p.).

Asimismo, en "El virrey de la adivinanza" (segunda serie) Palma sugiere que, a menudo, se le otorga mayor importancia a la "limpieza de sangre" (y a la nobleza) que a las riquezas: "el asturiano D. Fernando de Abascal era en sus verdes años un hidalgo segundón, sin más bienes que su gallarda figura y una rancia ejecutoria que probaba siete ascendencias de sangre azul, sin mezcla de moro ni judío" (n.p.). En "La investidura del hábito de Santiago" (cuarta serie), Palma describe el ritual para investir a los nuevos caballeros de la Orden de Santiago, una orden religiosa y militar (inaugurada en el Reino de León del siglo XII) entre cuyos objetivos principales destaca el de expulsar a los musulmanes de la península ibérica. En la tradición, se describe detalladamente la 
investidura, celebrada por un clérigo, quien, como parte de su pregón, exclama que el caballero nominado es "hidalgo de buen solar y que, en la limpieza de su ejecutoria ha comprobado no tener sangre de moro, hereje, ni judío" (n.p.).

La tradición palmina titulada "El ombligo de nuestro padre Adán” (cuarta serie) cuenta la historia del bachiller Juan del Castillo, quien, hallándose en lima en 1607, se atreve a cuestionar si, al carecer de madre, el Adán bíblico contaba con un ombligo. La polémica enfureció a los inquisidores limeños, quienes “[e]cháronse a espulgar en la vida, costumbres y antecedentes del acusado, y sacaron en limpio que el padre de Castillo había sido portugués judaizante y, por ende, recaía sobre el hijo la presunción de traer la conciencia entre la Biblia y el Alcorán, o lo que es lo mismo, de no hacer ascos a la ley de Moisés" (n.p.). Por consiguiente, el bachiller fue condenado y quemado por "hereje". En "La moda en los nombres de pila" (quinta serie), se menciona a un gallego de nombre David Gorozabel, quien, por culpa de su nombre y apellido de corte judío, casi es ajusticiado por la Inquisición.

Los “portugueses judaizantes" de Lima también protagonizan la tradición "La casa de Pilatos" (primera serie), en la que Palma habla sobre la historia de una antigua e imponente casa limeña, sede de negocios y reuniones entre comerciantes acaudalados. El autor señala que las leyendas cuentan que cien comerciantes judíos de origen portugués se reunieron en la casa y que un joven observó cómo estos se acercaron uno por uno ante una gran estatua con un Cristo crucificado y "descargaron sobre él un fuerte ramalazo" (n.p.). El joven, contó la anécdota a la Inquisición, que apresó inmediatamente a los judíos (n.p.). Tanto en esta tradición como en sus Anales, Palma corrobora la leyenda afirmando que: 
En la Biblioteca de Lima existe original el proceso de los portugueses, y de él sólo aparece que en la calle del Milagro existió la sinagoga de los judíos, cuyo rabino... era Manuel Bautista Pérez. El fiscal habla de profanación de imágenes... [por lo que] Pérez y diez de sus correligionarios fueron quemados en el auto de fe de 1639, y penitenciados cincuenta portugueses más, gente toda de gran fortuna. Parece que al portugués pobre no le era lícito ni ser judío, o que la Inquisición no daba importancia a descamisados. (Tradiciones, "La casa" n.p.)

La profanación de las imágenes religiosas cristianas es un estereotipo recurrente asociado con los judíos al igual que sus supuestos recelos hacia los rituales cristianos, como se observa en "De cómo a un intendente le pusieron la ceniza en la frente" (sexta serie). En esta tradición, Palma habla de un gobernador intendente de Guamanga en 1880, Demetrio O'Higgins, un "gringo" irlandés quien no atendió a los rituales religiosos del miércoles de ceniza. El pueblo dudaba su condición de católico, por el hecho de que O'Higgins hablaba español con acento extranjero, era "rubio como los judíos", tenía “pico en la nariz", mientras se especulaba además sobre su posible circuncisión (n.p.). Aunque, finalmente, el protagonista accede a participar en el ritual de cenizas (y aun tratándose de un relato de ficción), es posible que en la época de Palma aún exista un fuerte rechazo hacia la comunidad judía y una clara asociación de este colectivo con una conducta y unos rasgos físicos determinados.

En muchas tradiciones, se hace además hincapié en las abundantes riquezas de los judíos, asociados con la opulencia, la usura, la avaricia, la corrupción, los subterfugios 
económicos y su "conciencia de judío cambista" ("La soga arrastra”, sexta serie). En la tradición "Don Dimas de la Tijereta” (primera serie) Palma pone de manifiesto el imaginario antisemita asociado con el protagonista como su "nariz cicerona" y su apego excesivo hacia el dinero (Velázquez, Mirada 276-77). Su descripción de usurero "sin alma", probablemente le identifique con la imagen estereotipada del judío como ente maligno (276-77). En ¡A iglesia me llamo! (tercera serie), ambientada en 1575, observamos la descripción de unos españoles, entre los cuales uno se impacienta al ver que los demás no apuestan el suficiente dinero, y asevera: "Roñoso juego hacen vuesas mercedes y más parecen judíos tacaños" (n.p.). De este modo, se hace un paralelismo entre los jugadores que se resisten al derroche y los judíos.

Otro estereotipo común con el que se asocia los judíos es su intención de perjudicar a los cristianos mediante fechorías, como con el envenenamiento del agua de los pozos o provocando enfermedades mediante acciones o maldiciones. En "El judío errante en el Cuzco" (quinta serie) se cuenta un suceso que, según Palma, sucedió cuando el autor era joven:

En 1856 el tifus hizo estragos en el departamento del Cuzco. Calcúlase en más de cien mil el número de los que sucumbieron víctimas de la epidemia.... A la sazón era lectura muy popular en el Perú la novela de Eugenio Süe, titulada El Judio Errante... Según el escritor francés, el terrible flagelo conocido por cólera asiático es obligado compañero en la eterna peregrinación del zapatero de Jerusalén, a quien los pueblos españoles no llaman Ashaverus, sino Juan Espera en Dios, viajero que, ateniéndonos a los cuentos de viejas, recorre el mundo 
llevando en el bolsillo una moneda romana equivalente a real y medio... A muchos de los habitantes del Cuzco se los encajó entre ceja y ceja que aquella espantosa cifra de mortalidad no era producida por el tifus, sino por la presencia del huésped que llevaba a cuestas la maldición del Divino Maestro. Una mañana presentose en el pueblo de Zurite, a ocho o diez leguas de la ciudad del Cuzco, un extranjero, ante cuyo aspecto púsoso en conmoción el vecindario. Era un hombre pálido, enjuto, apergaminado y de ceja tan espesa que casi parecía una raya negra sobre los ojos. Las señas eran fatales. El hombre era el retrato del Judío tan pintorescamente descrito por Eugenio Süe.

Alborotáronse los vecinos de Zurite y el viajero fue a la cárcel... En vano el infeliz dijo que era español, que se llamaba Francisco Anselmo de Mendoza, que había estado en Jauja convaleciendo de una afección pulmonar y que, restablecido ya, no quería abandonar la sierra sin visitar antes los monumentos de la imperial ciudad de los incas. ... Y tanto por castigar al que fue despiadado para con Cristo en el camino al Gólgota, cuanto por vengarse del que creían portador de la peste, encendieron una hoguera en la plaza y achicharraron en ella al desventurado chápiro... [L]os de Zurito felicitaban al departamento porque, gracias a la energía de tan cristianos vecinos, la peste iba a desaparecer. Y en efecto. ¡Vean ustedes lo que hace la casualidad! Desde que los de Zurite quemaron al Judío Errante no volvió a ocurrir en el departamento un solo caso de peste. (n.p.)

Al igual que en las descripciones de otras minorías, en ocasiones, la actitud de Palma se muestra ambigua, puesto que en el pasaje hace hincapié en la superstición del 
pueblo, que juzga y ejecuta a un inocente, pero, por otra parte, deja en el lector la duda sobre el rol del supuesto judío en la propagación de la enfermedad.

Asimismo, en "Los judíos del prendimiento" (quinta serie), Palma parece simpatizar con los judíos portugueses, mencionando una historia que tiene lugar en 1636, cuando frente a la casa de un hombre, Antonio Balseyra Vasconcelos da Cota Pinheyro, se halla un escrito acusándolo de ser un judío. Según el autor, la Inquisición no necesitaba más pruebas para encarcelar a Balseyra y, al descubrir que era portugués, concluyeron que era judío y merecía la hoguera. Asimismo, Palma recuerda que se habían condenado a cien portugueses en 1635 y a otros once en 1639. Sus únicos crímenes, afirma el autor, fueron el de haberse enriquecido honradamente y, quizás, el hecho de ser acusados de conspiración para "arrancar estos reinos del Perú al dominio español" (n.p.). No es de extrañar, por lo tanto, la simpatía del autor hacia esta comunidad, asociada, en parte, con los ideales de la sublevación contra España. Por consiguiente, Palma concluye el relato afirmando que para los portugueses "[n]o había escape: o judío o revolucionario", por lo que eran ajusticiados despiadadamente (n.p.). Asimismo, el relato perdona a Balseyra, quien es liberado a condición de hacer penitencia y rebautizar a sus hijos, a quienes había bautizado con nombres excéntricos y por sí sólo, sin recurrir a un cura, "a usanza de judíos" (n.p.). Un caso similar ocurre en "Una vida por una honra" (segunda serie), en la que Palma habla sobre una amenaza de expulsión contra los judíos que se dispuso en Lima en la década de 1640, ante el temor de que estos pretendieran confabular contra España a favor de Portugal: 
... los portugueses residentes en Lima eran casi todos acaudalados e inspiraban recelos de estar en connivencia con el Brasil para minar el poder español. El $1^{\circ}$ de diciembre de 1640 se había efectuado el levantamiento del Portugal. El Santo Oficio había penitenciado y aun consumido en el brasero a muchos portugueses, convictos o no convictos de practicar la religión de Moisés. En 1642 dispuso el virrey que los portugueses se presentasen en palacio con las armas que tuvieran y que saliesen luego del país... Presentáronse en Lima más de seis mil; pero dícese que consiguieron la revocatoria de la orden de expulsión, mediante un crecido obsequio de dinero que hicieron al marqués.... Los enemigos del marqués contaban que cuando más empeñado estaba en perseguir a los judíos portugueses, le anunció un día su mayordomo que tres de ellos estaban en la antesala solicitando audiencia, y que el virrey contestó: «No quiero recibir a esos canallas que crucificaron a Nuestro Señor Jesucristo». El mayordomo le nombró entonces a los solicitantes, que eran de los más acaudalados mercaderes de Lima, y dulcificándose el ánimo de su excelencia, dijo: «¡Ah! Deja entrar a esos pobres diablos. Como hace tanto tiempo que pasó la muerte de Cristo, quién sabe si no son más que exageraciones y calumnias las cosas que se refieren e los judíos!». Con este cuentecillo explican los maldicientes el general rumor de que el virrey había sido comprado por el oro de los portugueses. (n.p.)

En esta tradición los judíos son asociados con la opulencia, sin embargo, la crítica parece centrarse en los españoles, tanto por su administración de las Colonias como por 
su corrupción, puesto que están dispuestos a doblegar sus ideales y repudiar su fe y su nación cuando se presenta la ocasión de obtener ganancias. ${ }^{30}$

En conclusión, desde el punto de vista de las elites peruanas decimonónicas, el país está repleto de enemigos u Otros, no solo autóctonos, sino también foráneos. A menudo, los dos conceptos se confunden, ya que lenguas y religiones minoritarias son consideradas ajenas al país, a pesar de ser observadas y utilizadas por habitantes establecidos en el Perú durante generaciones. De este modo, chinos o judíos peruanos son frecuentemente representados como enemigos de los peruanos, y en lucha contra el país. Al mismo tiempo, se desarrollan discursos contra los inmigrantes blancos, antaño lideres coloniales, pero ahora atacados, no por su etnia, sino por aspectos como su pobreza, afiliación política, u orientación sexual. Del mismo modo, los nativos son retratados como enemigos internos, y sus idiomas y religiones los convierten en "extranjeros en su propia tierra". Este colectivo se une, de este modo, a otros enemigos "internos", como es el caso de los afrodescendientes, las mujeres o los homosexuales, a menudo, culpados de “debilitar” el pueblo peruano.

\footnotetext{
${ }^{30}$ Otras tradiciones en las que se mencionan los judíos o se hace referencia a la religión hebraica son "Un proceso contra Dios" (2a serie), en la que se menciona fugazmente a un adinerado judío, al que un obispo logra bautizar, y "El caballero de la Virgen" (3a serie), ambientada en 1617. En esta última tradición un hombre desafía a cualquier "infiel" de lima a rebatir que la Virgen María fue concebida sin pecado. Aunque Palma afirma que en esa época la ciudad era "un hervidero de portugueses judaizantes", nadie se atreve a aceptar el desafío (n.p.).
} 
4. Mujeres, "marimachos" y "maricones": género y sexualidad en los discursos decimonónicos

Existe una importante diferencia entre los Otros extranjeros y los Otros nacionales. Los primeros pueden considerarse individuos foráneos dentro de una sociedad o país, y, en ocasiones, ciudadanos que, a pesar de encontrarse en suelo nativo, son tratados como "extranjeros" por sus connacionales. Este es el caso de los indígenas americanos, quienes pueden ser considerados ajenos a la nación en la que viven a pesar de ser nativos. ${ }^{31}$ Por otra parte, los Otros nacionales (autóctonos o locales) son aquellos que se identifican, culturalmente y étnicamente, como integrantes de la sociedad en la que nacen, pero, aun así, son clasificados como subalternos. El caso más claro es el de los homosexuales, las mujeres o los pobres, a menudo representados de forma simplista y agrupados dentro de un mismo espacio marginal imaginario junto a Otros de diverso tipo. Ejemplo de ello es la asociación de la mujer con el Otro "racial", y el consiguiente temor al mestizaje del que hablaremos en el Capítulo $5 .{ }^{32}$

\subsection{Mujer y otredad}

Tal como afirma la filósofa francesa Simone de Beauvoir (1908-1986) en su libro El segundo sexo (1949), la mujer ha sido tradicionalmente relegada a un plano

\footnotetext{
${ }^{31}$ Hoy en día, podría citarse el caso de los europeos y estadounidenses de herencia asiática, africana o latina, quienes son típicamente considerados extranjeros aun habiendo nacido en estos países y siendo descendientes de nativos.

${ }^{32}$ Véase el artículo de Elisabeth L. Austin: "Reading Transgression in Ricardo Palma's Tradiciones en salsa verde" (2014). Cabe mencionar El santo de Panchita (1859), una obra teatral escrito por Manuel Ascencio Segura y Ricardo Palma en la que afloran problemática cuestiones de género y estereotipos sobre la mujer decimonónica.
} 
secundario, como subordinada del hombre. Considerada un subproducto de este desde tiempos bíblicos -en cuanto a criatura nacida de la costilla de Adán-, la mujer debe mostrarse abnegada, sumisa, indefensa, superficial, femenina, altruista y sentimental. Estos rasgos se consideran parte de su esencia. Sin embargo, Beauvoir subraya que aspectos como la abnegación no son la vocación de la mujer, al igual que la esclavitud no es la vocación del esclavo (262). Beauvoir se opone precisamente a esta noción esencialista de la mujer que la retrata como un mero objeto sin voluntad, cuya personalidad es innata. Esta ideología se refleja en las representaciones de las mujeres de Palma, quien categoriza a sus heroínas en "tipos" distintos, dependiendo de aspectos como su edad o su etnia. Tal como nos recuerda Beauvoir, el comportamiento de la mujer no es intrínseco o inmanente, sino que desde su niñez es educada e inducida a comportarse de manera determinada: no "nace" siendo "mujer", sino que se "convierte" en una (264). En este sentido, Beauvoir comparte con el filósofo francés Jean-Paul Sartre (1905-1980) la idea de que "la esencia no precede la existencia" y el ser humano "no es nada" a priori (Beauvoir 264).

Para muchas mujeres latinoamericanas, el siglo XIX trae consigo una serie de influencias internacionales que afectan su situación en las sociedades patriarcales y jerarquizadas del periodo. Se popularizan los preceptos victorianos ingleses y se insiste en la importancia de una educación para las mujeres de clase alta que se centre en aspectos como la música y las artes, dejando a un lado las ciencias y los estudios de obras canónicas. Por otra parte, en 1876, al menos un 39 por ciento de la población femenina no sabe leer ni escribir, por lo que las mujeres de distintos estratos sociales sostienen distintas obligaciones (Mannarelli, Limpias 43). Madres, hijas y hermanas son a menudo 
utilizadas como elementos ornamentales y de prestigio para las familias privilegiadas, y se convierten en silenciosas imágenes públicas, forzadas a mantener una compostura y estética impecables. En este contexto, se establece un rígido orden social y unos roles determinados en la distribución familiar. Al igual que el cabeza del estado es secundado por el pueblo, el padre de familia domina las cuestiones familiares y se asegura de que sus miembros no se aparten de sus funciones y deberes. De este modo, la mujer se convierte en víctima de una inflexibilidad particularmente severa, y de un estricto control sobre su conducta, su cuerpo y sus impulsos: existe una "negación del cuerpo considerado como portador de los deseos y de las pasiones que necesitan ser reprimidas para conservar determinado orden social" (Mannarelli, Limpias 20-21). Las restricciones aplicadas al cuerpo y sus impulsos llevan a la "homogeneización social" (23). El cuerpo es un modelo que simboliza la sociedad, "[s]us fronteras pueden representar cualquier frontera percibida como amenazada o precaria" por los que "[t]anto en el cuerpo como en la sociedad... los márgenes son peligrosos" (23). Esta ideología está presente especialmente tras la Guerra del Pacífico, cuando los diarios chilenos describen a los peruanos como "enclenques y afeminados" y el Perú era retratado como "un país con sus fronteras violadas, como el cuerpo de una mujer sometida a la violencia masculina, a la violencia del fuerte, del apto, del vigoroso" (56). En ocasiones, la mujer es representada como un símbolo de la patria, un fenómeno que puede observarse en los trabajos de autores decimonónicos como Clorinda Matto de Turner. En su novela Aves sin nido, Matto retrata a unas heroínas convertidas en un ideal nacional de libertad y justicia en sus luchas contra la opresión institucional. Por otra parte, la inestabilidad de la mujer 
equivale al desequilibrio de la nación, por lo que para controlar el país es necesario supeditar el cuerpo femenino (Pratt 55).

En la obra de Palma, la mujer es la protagonista de numerosos relatos, aunque no deja de retratarse de manera ambigua por el autor. Generalmente, el autor describe a la mujer enfatizando su belleza, frivolidad y emotividad, aunque, en ocasiones, hace hincapié en su intelecto, equiparándola al hombre. Asimismo, Palma mantiene una estrecha amistad con mujeres intelectuales, entre las que destacan sus propias hijas, y las escritoras de su época como la argentina Juana Manuela Gorriti (1818-1892) y Clorinda Matto de Turner. El escritor no duda en brindar su apoyo a estas y a otras escritoras de la época, escribiendo críticas y comentarios laudatorios como el prólogo de las Tradiciones cuzqueñas (1884) de Matto (inspiradas en las Tradiciones de Palma). Por su parte, Palma utiliza para sus Tradiciones numerosas fuentes orales femeninas, tras las que, ocasionalmente, se esconde para hacer una mordaz crítica social (Sampson XIV). Por otro lado, sus protagonistas son típicamente portadoras de unos rasgos inmanentes que las convierten en sujetos estereotipados, designando a distintos "tipos" de mujer. Palma se distancia de las mujeres de su época, mostrando una actitud nostálgica hacia las jóvenes del pasado (colonial), alabando sus virtudes, su vivaz conducta y admirable semblante. El escritor utiliza los refranes y el humor para idealizar el pasado y sus heroínas, vinculando además a la mujer con los cambios políticos y económicos de su país (Sampson XIV, 51). En este sentido, Palma afirma que las costumbres y "la travesura de la limeña" han desaparecido, y se pregunta si todo "lo que lleva un sello de nacionalismo" sufrirá el mismo destino ("Predestinación”, primera serie, n.p.). Elisa Sampson considera que en las Tradiciones se construye una nueva "arcadia criolla" basada en creencias misóginas, 
donde las mujeres son utilizadas para reescribir las costumbres y usanzas de otro tiempo $(\mathrm{XIV}) .{ }^{33}$

Por otra parte, según Sampson, las mujeres a las que se dirige Palma no se asemejan a sus protagonistas, tratándose de lectoras más pasivas y apocadas, sin vínculos con las coquetas y exuberantes mujeres de su obra (Sampson XIII). Sus heroínas son casi siempre limeñas jóvenes (concretamente de unos veinte años), de pies diminutos, cintura fina, pequeña boca carmesí, y carácter alegre e impetuoso. Este es el caso de uno de sus personajes, Teresa Méndez, a quien representa como "una preciosa joven de veintiún años, de ojos grandes, negros, decidores, labios de fuego, brevísima cintura, hechicero donaire, todas las gracias, en fin, y perfecciones que han hecho proverbial la belleza de las limeñas" ("Dos millones”, primera serie n.p.). Otro ejemplo de mujer idealizada por el autor es la "tapada" limeña, cuyo atuendo consiste en una saya y un manto que deja visible tan sólo un ojo de su cara, a menudo considerado un instrumento para incitar con su misterio al sexo opuesto. Maida Watson nos recuerda que esta indumentaria es utilizada por las mujeres limeñas desde el siglo XVI hasta la segunda mitad del siglo XIX, tratándose de una costumbre que, desde sus orígenes, no es exenta de polémicas:

De acuerdo con algunos críticos, la moda de la saya y manto se origina en Arabia y llega a América con los conquistadores españoles en los primeros años del siglo XVI. Se usa también en México antes de fines del siglo XVI, donde el clero logró

\footnotetext{
${ }^{33}$ Palma conecta la representación de la sexualidad con su perspectiva sobre la marginalidad, la fragmentación y lo anecdótico, haciendo una interesante asociación entre diversos tipos de Otros (Sampson XIV).
} 
que sus feligresas eliminasen tal vestimenta en forma definitiva. En $1582 \mathrm{el}$ Tercer Concilio Limense la prohíbe por considerarla una moda con la que las mujeres solteras e incluso las casadas, ocultas por el traje, coqueteaban con los hombres en las procesiones de Corpus Christi y de Semana Santa. El nombre no es sino una versión del original español "tapadas de medio ojo" y que en Lima se convirtió en "tapada” a secas. (Watson, “Arte” 45; Cantuarias Acosta, 33)

En "La tradición de la saya y manto", Palma corrobora la presencia de la creencia de que estos atuendos podían ser utilizados para ocultarse y cometer actos socialmente inaceptables lejos de las miradas ajenas: “[p]ara las tapadas, en España y en todas las capitales de virreinato americano, la mantilla y el rebocillo eran los encubridores del coqueteo" (Palma, Cien 430).

Asimismo, el atuendo de la tapada puede relacionarse con uno de los rasgos típicamente atribuidos a la mujer: el misterio. Este rasgo está relacionado también con la “orientalización” de la figura femenina, ya que, según Palma, en las mujeres latinoamericanas (en este caso, ecuatorianas) "hay mucho de la mujer de Oriente", puesto que actúa de forma misteriosa y sugerente, “dejando adivinar voluptuosas y esculturales formas por entre los pliegues de la ligera gasa de su traje" ("El alma de Tuturuto", cuarta serie n.p.). Además de la sensualidad relacionada con lo oculto, según Simone de Beauvoir, delegar a la mujer al terreno de lo misterioso la transforma convenientemente en un Otro (263). El estereotipo de la mujer enigmática acarrea una serie de consecuencias, ya que implica que sus argumentos y quejas son incomprensibles, provocando una falta de comunicación que nunca se achaca a la ignorancia del hombre, 
sino al hecho de que la mujer es un ser ininteligible (Beauvoir 263). De este modo, el hombre puede obviar las enigmáticas demandas y necesidades de la mujer, una actitud que, finalmente, permite que el poder se quede en manos del hombre y las autoridades, preservando la jerarquía social patriarcal (263).

En cuanto a las implicaciones ideológicas asociadas con el atuendo de las tapadas, también cabe destacar el argumento de que estas mantienen la vestimenta colonial tras la independencia como desafío a la sociedad patriarcal y, a su vez, emancipación de la misma (Watson, “Arte” 45). En este caso, las reivindicaciones de las limeñas en cuanto a su posición social parecen mezclarse con cierto rechazo hacia el capitalismo y la globalización. Aunque el mercantilismo moderno ya está presente en muchos países (al menos) desde el Renacimiento, y se extiende, en buena medida, gracias imperialismo europeo, en Latinoamérica el movimiento de mercancías gana nuevo vigor tras las independencias, gracias al auge de la publicidad impresa. Por consiguiente, tras siglos de existencia, la saya y el manto sucumbe a las modas internacionales, como la francesa, que reinaba en un mundo cada vez más consumista y comercialmente unificado. Para 1860, época en la que Palma escribe sus tradiciones, la tapada ya es símbolo del pasado:

Nuestras abuelas, que eran más risueñas que las cosquillas, supieron hacer de la vida un carnaval constante. Las antiguas limeñas parecían fundidas en un mismo molde. Todas ellas eran de talle esbelto, brazo regordete y con hoyuelo, cintura de avispa, pie chiquirritico y ojos negros, rasgados, habladores como un libro y que despedían más chispas que un volcán en erupción. ("La conspiración de la saya y manto", cuarta serie n.p.) 
La saya y el manto han desaparecido, llevándose consigo la sal epigramática, la espiritual travesura de la limeña. ¿Estará condenado nuestro pueblo a perder, de día en día, lo que lleva un sello de nacionalismo?" (“Predestinación”, primera serie, n.p.).

Con tono nostálgico, Palma favorece la belleza de las tapadas y las criollas limeñas frente a las mujeres de su época. Este icono nacional, cuyo encanto la convierte en dueña de la voluntad de los hombres, representa el encuentro entre la tradición y la modernidad, la Colonia y la República. Sin embargo, no todos sus rasgos son positivos, ya que las tapadas desafían la razón con su índole traviesa, maliciosa e ingeniosa: "hacen de la vida un carnaval constante" y desdeñan el trabajo para centrarse en el individualismo, el libertinaje, la sensualidad y el lujo (Velázquez, Mirada 291-92). Palma compara las mujeres de ambas épocas refiriéndose a las polémicas que rodean el rol de la mujer en la sociedad, y manteniendo una actitud deliberadamente ambigua: "no entro ni salgo en lo de si es quimérico y fruto de fantasías soñadoras eso de igualar a la mujer en derechos con el varón; ni en si, alcanzado el propósito, desparecerían el hogar con todos sus encantos y la familia con todos sus privilegios" (Palma, Tradiciones Peruanas completas 1345-48). Con estas palabras, el autor parece desvincularse del debate, aunque sugiere que la igualdad de género es un concepto "utópico" que, de hacerse realidad, destruiría la estructura familiar. En otras ocasiones, Palma se pone de parte de la mujer:

No sé quién sostuvo que las mujeres eran la perdición del género humano, en lo cual, mía la cuenta si no dijo una bellaquería gorda como el puño. Siglos y siglos 
hace que a la pobre Eva le estamos echando en cara la curiosidad de haberle pegado un mordisco a la consabida manzana, como si no hubiera estado en manos de Adán, que era a la postre un pobrete educado muy a la pata la llana, devolver el recurso por improcedente; y eso que, en Dios y en mi ánima, declaro que la golosina era tentadora para quien siente rebullirse una alma en su almario. ¡Bonita disculpa la de su merced el padre Adán! En nuestros días la disculpa no lo salvaba de ir a presidio, ... Aceptemos también los hombres nuestra parte de responsabilidad en una tentación que tan buenos ratos proporciona, y no hagamos cargar con todo el mochuelo al bello sexo. ("D. Dimas de la Tijereta", primera serie n.p.)

Otra tradición en el que Palma muestra una actitud ambigua hacia la mujer es “ßBeba, padre, que le da la vida!” (segunda serie), protagonizada por doña Ana de Borja, quien ejerce de virreina del Perú temporalmente, entre 1668 y 1669, cuando su esposo, el virrey, se tiene que ausentar. El autor afirma que "[e]l conde de Bornos decía que «la mujer de más ciencia sólo es apta para gobernar doce gallinas y un gallo»”, pero Palma se dispone a rebatir esta idea contando la historia de doña Ana:

¡Disparate! Tal afirmación no puede rezar con doña Ana de Borja y Aragón que, como ustedes verán, fue una de las infinitas excepciones de la regia. Mujeres conozco yo capaces de gobernar veinticuatro gallinas... y hasta dos gallos. Así como suena, y mal que nos pese a los peruleros, hemos sido durante diez meses gobernados por una mujer... y francamente que con ella no nos fue del todo mal 
... [d]e la tal doña Ana algo que no se le habría ocurrido al ingenio del más bragado gobernante, y que prueba, en substancia, cuán grande es la astucia femenina y que, cuando la mujer se mete en política o en cosas de hombre, sabe dejar bien puesto su pabellón... ¡A Ahora digan ustedes si no fue mucho hombre la mujer que gobernó el Perú! (n.p.)

A pesar de sus palabras laudatoria, el autor afirma "[m]ujeres conozco yo capaces de gobernar veinticuatro gallinas... y hasta dos gallos", una afirmacion que parece conceder, de forma paternalista, que la mujer puede gobernar, pero siempre de manera limitada (n.p.).

Al margen de sus representaciones ambiguas, el rol de las mujeres es fundamental en las Tradiciones, puesto que su presencia responde a una serie de necesidades dentro de sus tramas (Velázquez, Mirada 286). Según Marcel Velázquez, en primer lugar, las mujeres de Palma son representantes de las voces marginales en el espacio público dentro de una narrativa androcéntrica; en segundo lugar, son el "objeto de deseo" que pone en marcha la historia; y finalmente, representan el estereotipo criollo, caracterizado por su "gracia, talento innato, transgresión y disfrute" (286). Asimismo, Velázquez habla de tres personajes femeninos recurrentes en las Tradiciones: "la mujer pobre que sólo posee su belleza"; "la viuda rica que compra amor con dinero"; y "la mujer despechada que se venga del ingrato" (287). En la tradición "La emplazada" (segunda serie), Palma describe a dos mujeres que se ajustan a esta categorización. Por una parte, el autor describe a Gertrudis, una joven esclava mulata que consigue salir de su precaria situación social gracias a su garbo y su belleza. Sus dotes hacen, además, que Pantaleón, un atractivo 
esclavo, se enamore de ella. Por otra parte, la condesa Doña Verónica Aristizábal, que acoge a los dos esclavos, aprovecha su posición para tener una relación con el joven. Sin embargo, al descubrir que este ama a Gertrudis, se venga del amante ordenando su muerte.

Es importante subrayar que, a pesar de su irrupción dentro de la narrativa androcéntrica, el control del cuerpo de la mujer es considerado fundamental a la hora de mantener la estructura social establecida intacta. El deterioro de la nación se asocia con la corrupción de los cuerpos, los cuales se vuelven viciados, afeminados o racialmente debilitados. De ello, a menudo se culpa a la mujer y su "irresponsabilidad" al transmitir esos rasgos a su prole, como podemos observar en la tradición de Palma "Matrícula de Colegio" incluida en Tradiciones en salsa verde. En esta obra se recogen las tradiciones en las que el autor se permite utilizar un lenguaje más escabroso y una temática marcadamente licenciosa. Como analizaremos con más detenimiento en la sección 4.5, dedicada a la representación de la homosexualidad en la obra de Palma, en "Matrícula" se mezclan distintos Otros dentro de un solo núcleo familiar que comprende a una mujer indígena, un extranjero (italiano pobre) y tres niños asociados con la homosexualidad. En su encuentro con el director de una nueva escuela, éste pregunta la razón de la "voz de flautín" de dos de los pequeños, a lo que uno responde que su madre tan solo tenía dos pechos, por lo que sólo fue posible alimentar a dos de los tres hermanos, quienes, por consiguiente, salieron "pobrecitos de voz" (66). El pasaje no sólo asocia la "voz de flautín" con el "afeminamiento" de los niños, sino que culpabiliza a su madre por ese "defecto". La necesidad de establecer un control sobre el sedicioso cuerpo femenino es un tema recurrente en los discursos decimonónicos, revelando la creencia, entre otras, de 
que la mujer podía transmitir cualidades -normalmente negativas-a su prole. En la tradición, cuando la madre india alimenta a sus hijos, estos se vuelven "afeminados", por lo que la leche materna parece adquirir un rol fundamental dentro de la sociedad: su influencia resulta central en la formación de la personalidad de los futuros hombres.

Otras tradiciones de Palma, mencionan fugazmente esta ideología, como en "De esta capa, nadie escapa" (sexta serie), en la que el autor afirma: “[e]sa propensión a ensuciar paredes la hemos adquirido los limeños con la primera leche" (n.p.). Es importante subrayar el hecho de que en el siglo XIX “el rol maternal no parecía definir la identidad de las mujeres", por lo que "[1]os niños podían ser criados, e incluso amamantados, por mujeres de clase subalterna" que a menudo eran culpadas de la conducta de los pequeños (Mannarelli, Limpias 16). Asimismo, en "La victoria de las camaroneras" (séptima serie), Palma describe a uno de sus personajes, don Diego Ladrón de Guevara, como el "cuñado de leche de un oidor de la Real Audiencia, por cuanto era hermano de leche de la esposa de su señoría" (n.p.). De este modo, el autor sugiere la importancia de la leche materna para establecer el parentesco. Sin embargo, existen otros factores que determinan el desarrollo social desde la infancia, tal como sugiere Clorinda Matto de Turner en su novela Herencia (1895): "la principal causa que la medicina reconoce para la mayor propagación de las mujeres está en el exceso de los padres que abusan del placer sin medida; y por eso, allá donde la moderación rige al amor, nacen varones robustos, moral y físicamente" (54). Esta actitud concuerda con la ideología dominante tras el desastre de la Guerra del Pacifico, y el auge de discurso a favor de la formación de varones fuertes y masculinos y mujeres saludables que no sucumbieran a los espejismos del mundo material y los placeres frívolos (Mannarelli, Limpias 56, 120). 
El control del cuerpo femenino puede llevarse a cabo de manera directa, estableciendo obligaciones o prohibiciones legales o sociales, o de manera indirecta, divulgando discursos que fomentan una serie de preceptos ideológicos o morales. Estos discursos son a menudo protagonizados por mujeres idealizadas y presentadas como modelos a imitar, frente a sus antagonistas, cuyas conductas deben evitarse. En la tradición "La Protectora y la Libertadora" (séptima serie), Palma describe a dos tipos de mujer, mostrando un modelo femenino "ideal" frente a su opuesto. Las descripciones analizan tanto su conducta como sus rasgos físicos y estéticos, con un fin visiblemente didáctico y moralizante:

...puedo establecer cardinales diferencias entre ambas. Física y moralmente eran tipos contrapuestos. En la [Rosa] Campusano vi a la mujer con toda la delicadeza de sentimientos y debilidades propias de su sexo. En el corazón de Rosa había un depósito de lágrimas y de afectos tiernos, y Dios le concedió hasta el goce de la maternidad, que negó a la [Manuela] Sáenz. Doña Manuela era una equivocación de la naturaleza, que en formas esculturalmente femeninas encarnó espíritu y aspiraciones varoniles. No sabía llorar, sino encolerizarse como los hombres de carácter duro. La Sáenz renunciaba a su sexo, mientras la Campusano se enorgullecía de ser mujer. Ésta se preocupaba de la moda en el traje, y la otra vestía al gusto de la costurera. Doña Manuela usó siempre dos arillos de oro o de coral por pendientes, y la Campusano deslumbraba por la profusión de pedrería fina. La Campusano perfumaba su pañuelo con los más exquisitos extractos ingleses. La otra usaba la hombruna agua de verbena. Decididamente, Rosa 
Campusano era toda una mujer; y sin escrúpulo, de haber sido yo joven en sus días de gentileza, me habría inscrito en la lista de sus enamorados...platónicos. La Sáenz, aun en los tiempos en que era una hermosura, no me habría inspirado sino el respetuoso sentimiento de amistad que le profesé en su vejez. La Campusano fue la mujer-acápite. La Sáenz fue la mujer-hombre. (n.p.)

Nótese cómo Rosa Campusano se asocia con una serie de rasgos que incluyen la delicadeza, el llanto fácil, la gentileza y el altruismo. Paradójicamente, estos rasgos dibujan a la mujer "perfecta" pero también representan sus "debilidades", indicando que la mujer ideal es frágil y sumisa. Ella debe dedicarse a los demás, especialmente cuando la Providencia le concede "el goce de la maternidad". Por otro lado, también se da a entender que la marginalidad es el lugar apropiado y "natural" de la mujer, y, cuando Manuela (la némesis de Rosa) intenta obtener a un rol central y de poder, mostrándose segura de sí misma, pierde todos los atributos que, para Palma, la identifican como mujer. El protagonismo es incompatible con la mujer y, por consiguiente, se "convierte" en hombre. La transformación de Manuela es tanto interna como externa: estéticamente viste como un hombre, moralmente se comporta como un varón, y físicamente, a pesar de tener rasgos femeninos, es incapaz de tener hijos al igual que los hombres. Esta castración simbólica es una consecuencia tanto natural como divina, ya que Manuela es una "equivocación de la naturaleza" y la Providencia la castiga negándole la maternidad. Por lo tanto, cuando la mujer se aparta del rol que se le asigna se convierte en una amenaza tanto para los hombres como para la sociedad; es un cuerpo que se escapa al 
control social, un Otro monstruoso y masculinizado que amenaza emascular al varón arrebatándole su autoridad y negándose a colaborar con la continuidad de la especie.

\subsection{Mujeres y estética}

El control del cuerpo femenino a menudo pasa por la regulación tanto de su conducta como de su aspecto. Para finales del siglo XIX, el orden y el progreso de la nación es asociado con la limpieza tanto de sus espacios públicos como de sus habitantes, y especialmente de la mujer (Mannarelli, Limpias 47). La higiene, la salud y la educación son fundamentales para dejar atrás la "barbarie" y adentrarse en el progreso y la “civilización” (47). Al igual que en otros periodos, en la sociedad capitalista decimonónica la estética femenina es una importante fuente de debate. Sin embargo, en esta época se propaga una serie de elementos publicitarios que amplifican la atención tanto de hombres como de mujeres hacia las cuestiones estéticas. El uso de productos cosméticos no es una práctica reciente en la sociedad decimonónica; sin embargo, el auge de la publicidad impresa acelera la diseminación de nuevas ideas sobre las virtudes de la cosmética y su rol indispensable, especialmente para la mujer. Según Marcel Velázquez, los elementos publicitarios "contribuyen a la cristalización del imaginario relacionado con los subalternos, como es el caso de la mujer y su identificación con los discursos higienistas" (Mirada 257). Según Velázquez, los productos de belleza desempeñan tres funciones: “a) enlazan a la mujer local con las redes mundiales del comercio; b) satisfacen y desafian las políticas del blanqueamiento que sostenían las fantasías raciales de la élite; y e) configuran al sujeto femenino como objetivo privilegiado en el consumo familiar de bienes novedosos y modernos" (257). 
Como hemos podido observar en la tradición de "La Protectora y la Libertadora" (séptima serie), la cosmética y el atuendo femeninos son tan importantes que, de no estar presentes, amenazan la "feminidad" de la mujer. Por otra parte, la mujer es víctima de una doble moral en una sociedad que la obliga a consagrarse por la estética y, por la misma razón, la condena por su frivolidad y superficialidad. Estas cuestiones afloran de manera visible en la obra de una de las escritoras contemporáneas de Palma, especialmente la novela Blanca Sol (1889), de Mercedes Cabello, donde su protagonista es víctima de la doble moral con la que se juzgan las mujeres de la época:

Decían que Blanca al bajar del coche o al subir el peldaño de una escalera se levantaba con garbo y lisura el vestido para lucir el diminuto pie, y más aún la torneada pantorrilla. ¡Mentira! Blanca se levantaba el vestido para lucir las ricas botas de cabritilla, que por aquella época costaban muy caro, y solo las usaban las jóvenes a la moda de la más refinada elegancia. Gustaba más excitar la envidia de las mujeres con sus botas de abrochadores con calados, traídas directamente de Paris, que atraer las miradas de los hombres con sus enanos pies y robustas pantorrillas. (6)

La mujer, por lo tanto, parece dejar de suscitar interés por sí sola. El cuerpo sin adorno es síntoma de pobreza y no es deseable en un mundo mercantil, "[e]1 verdadero objeto de deseo en una sociedad capitalista ya no es el cuerpo y su promesa de seducción y placer, sino el objeto que tiene un alto valor de cambio en el mercado" (Velázquez, Mirada 233). Por lo tanto, la mujer no genera erotismo de manera independiente, los 
elementos que la "cubren", el rico atuendo y la cosmética, son la verdadera fuente de sensualidad.

La difusión de las modas también incita a las mujeres de etnia no blanca a aclarar su tez mediante el uso de productos cosméticos e higiénicos para la piel. Estos además satisfacen los ideales de blanqueamiento de las élites y convierten a la mujer en la consumidora por excelencia dentro de la familia (Velázquez, Mirada 257). Sin embargo, las limeñas son víctimas de un condicionamiento que las lleva a utilizar productos de belleza que en ocasiones resultan dañinos. En la revista La Bella Limeña, del 21 de abril de 1872 (año 1, no. 3), se publican unos anuncios cuyo propósito es interesar al público femenino. La perfumería Atkinson publicita sus jabones de glicerina y almendras, prometiendo su eficacia "para blanquear, suavizar y hermosear la cútis", indicando sus supuestas cualidades blanqueadoras de la piel (24). En el tercer número de la misma revista aparece otro anuncio que reza: "[b]elleza, hermosura, decencia y blancura, tal es lo que se consigue con la gran Pomada Filoménica" (24). De este modo, no sólo se hace una asociación directa entre la blancura y la belleza estética, sino también entre el candor y la virtud moral o la "decencia". Paradójicamente, en el número del 12 mayo de 1872 de la misma revista también se publica un artículo con título "La frivolidad: estudio social sobre la mujer" de Faustina S. de Melgar, donde se insiste en la importancia de educar a las mujeres puesto que estas "en nada piensan sino en los colores que sientan mejor a su rostro y en las joyas que han de lucir en la ópera para eclipsar a fulanita o menganita" (42). Por lo tanto, la revista convierte a la mujer en víctima de esa doble moral, animándola, por un lado, a usar productos de belleza, y por otro, la critica por el uso de los mismos. Clorinda Matto de Turner también se hace eco del auge de la moda entre las 
mujeres de finales del siglo XIX, y de la doble moral a la que se ven expuestas. En su novela Herencia Matto describe la reacción de las mujeres ante el auge de los comercios en Lima: “[el] almacén era desde la puerta, una serie de sorpresas que narcotizaba a las mujeres, las engañaba como tiernas criaturas, y haciéndolas perder todo juicio, las obligaba a dejar el puesto de la casa, resignándose con verdadero heroísmo al ayuno del estómago" (38).

Otro ejemplo sobre la conexión entre la estética y el color de la piel aparece en la Guía histórico-descriptiva de Manuel Atanasio Fuentes (1820-89), en la que el autor hace la siguiente descripción de las mujeres limeñas:

El color de los limeños... es trigueño, pálido y amarilloso, siendo, por lo común, mas blanco el de las mujeres. No comprende un gran número de estas que el color natural es el mas bello, y deseando asemejarse a las europeas, cuya tez ostenta el blanco y el rosado debido a la naturaleza del clima bajo que nacen, emplean, con profusión, los colores artificiales que no solo no prestan hermosura, sino que atacan la salud y estampan en el rostro los signos de una vejez prematura. (24142)

En el pasaje, Fuentes alaba la naturalidad frente a la cosmética y critica las intenciones de parecerse a las europeas mediante el uso de "colores artificiales". Tal actitud se asemeja a la de Palma en su tradición "La gatita de Mari-Ramos" (segunda serie), ambientada en "la época del trigésimo cuarto virrey del Perú", donde habla de la mujer peruana en los siguientes términos: 
Veinte abriles muy galanos; cutis de ese gracioso moreno aterciopelado que tanta fama dio a las limeñas, antes de que cundiese la maldita moda de adobarse el rostro con menjurjes, y de andar a la rebatiña y como albañil en pared con los polvos de rosa y arroz; ojos más negros que noche de trapisonda y velados por rizadas pestañas; boca incitante, como un azucarillo amerengado; cuerpo airoso, si los hubo, y un pie que daba pie para despertar en el prójimo tentación de besarlo; tal era, en el año de gracia de 1776, Benedicta Salazar. (n.p.)

En esta tradición se mezclan opiniones contradictorias, rechazando el uso de productos cosméticos por parte de la mujer, pero haciendo hincapié en su aspecto físico. Al igual que muchas de sus tradiciones protagonizadas por mujeres, Palma empieza su retrato de Benedicta centrándose en su estética para luego pasar a describir su personalidad. Este talante parece dar precedencia al aspecto físico frente al moral, ya que sus personajes femeninos a menudo carecen de profundidad y se caracterizan por una identidad unidimensional. Muchas de las tradiciones de Palma se ajustan al modelo de discursos decimonónicos con un fin didáctico. Su propósito es el de reforzar las distinciones categóricas entre seres humanos, especialmente en los discursos que retratan a mujeres y a otros subalternos como los Otros raciales.

\subsection{Mujeres y "raza"}

El ideal de belleza de Palma parece ajustarse a mujeres de tez clara o fenotípicamente mezcladas, pero raramente encumbra a nativas o afroperuanas, que son 
típicamente delegadas a roles de vendedoras o labradoras. Por otro lado, es importante subrayar el hecho de que una fuente fundamental en las Tradiciones de Palma es su abuela, una mujer de color, por lo que sus descripciones de los subalternos raciales son ambiguas y cambiantes. La mujer es considerada la responsable de "mejorar la raza", por lo que es la encargada de hacer lo posible para unirse en matrimonio con hombres de "raza" "superior" o "similar" (Oliart, "Poniendo" 264). Al mismo tiempo, debía inculcarse a los hombres "no blancos" o "menos blancos" que su virilidad era inferior, por lo que no debían ni interferir en las uniones de mujeres con hombres blancos, ni casarse con mujeres de etnias "inferiores" (265). Por ende, pudo existir la creencia de que el hombre es el progenitor más influyente en la transmisión de rasgos raciales y morales, puesto que, debido al "carácter frágil" de la mujer, si un hombre blanco se une con una mujer no blanca, su prole heredará una tez más parecida a la del padre. Si sucediera lo contrario, la descendencia se vería afectada de manera más indisoluble por los rasgos no blancos del progenitor masculino, quien sería el culpable de "atrasar" la "raza" y el "blanqueamiento".

Según Ann Twinam, los hombres de tez oscura no disponían de muchas opciones para lograr el "blanqueamiento" de su prole ya que sólo podían optar por el matrimonio con mujeres de su misma etnia o con las de tez clara que fueran plebeyas o tuvieran algún tipo de estigma social que le impidiera contraer matrimonio con un hombre blanco (Purchasing 106-07, 110, 120-21). Por otro lado, las mujeres de "raza inferior" disponían de varias opciones, como el concubinato, las relaciones extramatrimoniales o el matrimonio con hombres de tez más clara (106-07, 110, 120-21). Consecuentemente, las mujeres afroperuanas e indígenas se convierten en entes peligrosos, que amenazan el 
éxito del blanqueamiento social. En este sentido, a menudo se subraya el supuesto poder seductor de las mujeres pardas, mulatas, o mestizas, quienes pueden doblegar la voluntad de los hombres de tez clara. Esta actitud emerge en la tradición de Palma "Genialidades de la 'Perricholi'” (cuarta serie), en la que se describe a Micaela Villegas, llamada 'la Perricholi', de posible etnia indígena o mestiza, cuyo atractivo no reside en su belleza, sino en su magnetismo:

¿Fue la Perricholi una belleza? No, si por belleza entendemos la regularidad de las facciones y armonía del conjunto; pero si la gracia es la belleza, indudablemente que Miquita era digna de cautivar a todo hombre de buen gusto. ... su rostro oval y de un moreno pálido ... sus ojos eran pequeños, negros como el chorolque ... hombros incitantes y seno turgente. (n.p.)

Como podemos observar, sus cualidades cautivadoras se mezclan con sus rasgos estéticos, su rostro "de un moreno pálido" y sus ojos "negros como el chorolque". Asimismo, en la tesis de Clemente Palma, la mulata cuarterona (también llamada “china") es otro ejemplo de mujer descrita en términos "raciales", haciendo hincapié en su nominal naturaleza provocativa y seductora, que necesita ser dominada sexual y físicamente (Porvenir 29; Velázquez, Mirada 270). ${ }^{34}$

\footnotetext{
${ }^{34}$ En la tradición "El alma de Tuturuto" (cuarta serie), Palma parece asociar a la mujer ecuatoriana con el Otro étnico y religioso de Oriente Medio: "[1]a guayaquileña tiene la belleza del diablo; ... En ella hay mucho de la mujer de Oriente" (n.p.).
} 
Las mujeres "racialmente" marcadas no sólo son una amenaza sexual, sino también social, cuando son acogidas en el seno de las familias blancas. Este es el caso de Gertrudis, la joven esclava que protagoniza "La emplazada", una mujer visiblemente sexualizada, ya que es descrita por Palma como una joven "fresca como un sorbete, traviesa como un duende, alegre como una misa de aguinaldo y con un par de ojos negros, tan negros, que parecen hechos de tinieblas" (n.p.). Gertrudis es un ejemplo de mujer mulata acogida en el seno de una familia blanca que indirectamente contribuye a la destrucción del hogar de acogida, ya que se enamora de un esclavo, también mulato, amante de su ama.

Las sirvientes subalternas son consideradas particularmente peligrosas cuando son encargadas del cuidado de los hijos en calidad de cuidadoras o nodrizas. Angélica Palma describe esta situación en su novela Vencida (1918), en la que describe el paisaje urbano repleto "de chiquillos de todas las edades, gorgojeando los bebes en sus cochecitos y correteando los mayorcitos bajo la vigilancia, no siempre muy cuidadosa, de sus criadas, mestizas y negras en su mayoría" (105). Su falta de cuidado se asocia con su etnia y, entre otras cuestiones, se refleja en la alimentación y el cuidado de las jóvenes generaciones. Una situación similar ocurre en la ya mencionada tradición "Matrícula de colegio", en la que una madre indígena cría (y amamanta) a sus hijos y estos se vuelven "afeminados" (Tradiciones en salsa 65-66). Por lo tanto, las mujeres no blancas son consideradas una amenaza a distintos niveles, puesto que desafían la "mejora de la raza", seducen a los hombres blancos, y amenazan el desarrollo social al infundir valores y cualidades negativos en las nuevas generaciones. 


\subsection{Marginalidad y otredad de género}

En los discursos decimonónicos emergen numerosas descripciones de Otros marcados por la pobreza, la prostitución, el adulterio, el amancebamiento, la ilegitimidad, e incluso el incesto o la pedofilia. María Mannarelli indica que la tasa de matrimonios en el Perú es particularmente baja, tanto en la Colonia como en el siglo XIX, por lo que se intuye que la convivencia, o amancebamiento, era una práctica común (Limpias 207). La relativa escasez de familias nucleares es corroborada por los censos de 1908, 1920 y 1931, en los que "más de la mitad de la población mayor de catorce años se autocalificó como soltero" (208):

A esto correspondía un alto porcentaje de nacimientos fuera del matrimonio, en esta época todavía considerados como ilegítimos: alrededor de un 50 por ciento a lo largo del periodo. Según las estadísticas disponibles, los nacimientos de ilegítimos en la ciudad exhibían porcentajes tan o incluso mas altos que en Lima colonial... [E]s difícil imaginar la maternidad como algo deseado... Domesticar la maternidad se convertía en una de las campañas más difíciles de ganar para los que se comprometieron con esta cruzada. (208)

A menudo, lo subalternos son acusados de uno o más "pecados" como el adulterio, el amancebamiento, la ilegitimidad, potenciados por el hecho de ser mujeres, por su orientación sexual, por ser extranjeros o por su otredad étnica o religiosa, entre otros. La pérdida de la honra, especialmente en el caso de la mujer, puede ser tanto una causa como una consecuencia de tales acusaciones, convirtiendo a los subalternos en 
exiliados sociales sin posibilidad de redención. ${ }^{35} \mathrm{El}$ concepto de la honra está presente desde la antigüedad y en su sentido clásico español a menudo se hace una diferenciación entre "honor" y "honra". El primero se asocia con el decoro de una persona en su vida privada, mientras que la "honra" se entiende como la conservación de una imagen intachable en el espacio público, es decir, la reputación. En el Diccionario de la Real Academia Española, la diferencia entre los dos términos se desdibuja, ya que el "honor" se define del siguiente modo:

1. m. Cualidad moral que lleva al cumplimiento de los propios deberes respecto del prójimo y de uno mismo.

2. m. Gloria o buena reputación que sigue a la virtud, al mérito o a las acciones heroicas, la cual trasciende a las familias, personas y acciones mismas de quien se la granjea.

3. m. Buena opinión granjeada por la honestidad y el recato en las mujeres. (n.p.)

Para que una persona pudiese conservar el honor o la honra se requería el cumplimiento de una serie de obligaciones sociales que, de no llevarse a cabo, ocasionaban su perdida. La honra era considerada una cualidad hereditaria y, tal como podemos observar en la tercera definición, existe una importante conexión entre la honra y la mujer. Su pérdida típicamente deja una mancha indeleble en toda la familia, ya que su imagen pública queda destruida frente a la opinión social, ocasionando repercusiones

\footnotetext{
${ }^{35}$ Véanse los capítulos cuatro y cinco del libro de María Mannarelli, Pecados públicos: la ilegitimidad en Lima, XVII. 1993. Centro de la Mujer Peruana Flora Tristán, 2004.
} 
que incluyen la pérdida del patrimonio y la posición social. De este modo, se hace fundamental preservar la honra de la mujer, controlando su cuerpo y su conducta, y confinándolas en el ámbito doméstico, especialmente para las mujeres de clase alta. Según María Mannarelli, entre finales del siglo XIX y principios del XX:

[E]l sistema del honor seguía ofreciendo pautas de conducta y las calles no eran apropiadas para la mantención de la reputación femenina. Unas, las que pretenden un estatus, deben ir acompañadas. Ir solas puede ser peligroso en diferentes sentidos. Es probable que el peligro físico no acechara a estas mujeres. Pero el peligro social, la deshonra, sí. Para las mujeres de menos estatus, la calle era además de un lugar de trabajo -lavanderas y vendedoras por ejemplo- el lugar de vida social. (33)

Por lo tanto, en la época moderna, la honra está a menudo relacionada con la clase social y su pérdida puede suponer la causa o la consecuencia de una o más situaciones socialmente inaceptables como es el caso de la pobreza, la prostitución, o el adulterio. Los problemas de la honra y la prostitución aparecen conectados en la tradición de Palma "El Nazareno" (primera serie) donde se narra la historia de una bellísima y recatada mujer que, seducida por El capitán Don Diego de Arellano, pierde irremediablemente su honra:

Pocas horas después había en Lima un escándalo más. La deshonra de una mujer hermosa es una victoria para las que envidian su belleza. La desventurada, 
después de buscar vengador en su hermano, que fue muerto en duelo por $\mathrm{D}$. Diego, tuvo que esconder sus lágrimas y su vergüenza entre las rejas de un claustro. El descrédito... no germinaba tan sólo entre la gente acomodada. Su mala reputación se había popularizado hasta tal punto, que ningún mendigo se atrevía a llegar a la puerta de su casa... (n.p.)

En la misma tradición, Palma habla de Rosa, una hermosa joven caída en desgracia. Hija de unos padres de clase media, fue seducida por un "libertino", quien no dudó en dejarla después de seducirla. Por consiguiente, "[a]nte la publicidad de su deshonra ... los padres de Rosa perdieron la razón" y la joven quedó en la indigencia teniendo que cuidar de los dos ancianos (n.p.). En este caso, los efectos directos de la perdida de la honra son, primero, el colapso de la reputación familiar, segundo, el deterioro de la salud física y psicológica (especialmente la de los padres), y, tercero, la pérdida del estatus socioeconómico ya que "[1]a más espantosa miseria reinaba en torno suyo". El autor señala la rectitud moral y belleza de la joven que se sacrifica para cuidar a sus padres, Rosa es un "ángel que, lleno de abnegación y de ternura, había sido colocado por Dios para velar sobre los últimos días de dos ancianos" (n.p.). Aunque la situación no la lleva a prostituirse, Palma sugiere que este es destino de muchas mujeres bellas que pierden la honra: "si ella lo hubiera querido habría cambiado su situación por el lujo y la opulencia, poniendo como otras desventuradas en subasta sus encantos. Sobre la tierra abundan viejos cínicos, que derrochan el oro para comprar las caricias de esos ángeles manchados con el lodo de la prostitución.” (n.p.). 
Junto a la prostitución, existen otros factores que a menudo son asociados dentro de un mismo imaginario social. Según Ann Twinam, existe un "trío mortal" de atributos inmorales: los defectos de casta, la ilegitimidad y las relaciones extramatrimoniales (Purchasing 110). A pesar de ser "pecados" cometidos tanto por hombres como por mujeres, bajo la mirada social estos afectan principalmente (o únicamente) a la mujer y su honra. Sebastiana, protagonista de la tradición palmina "Mujer y tigre" (Primera Serie), es un ejemplo de mujer que encarna dos de esos defectos, puesto que mantiene relaciones extramatrimoniales y tiene dos hijos ilegítimos como consecuencia de esa relación. Sebastiana es una joven heredera seducida por un joven seminarista, que termina teniendo dos hijos ilegítimos aferrándose a la promesa de compromiso de su amado. Sin embargo, el joven decide casarse con otra mujer, por lo que Sebastiana le conduce a una trampa, mata a los dos niños delante del padre y despedaza a su antiguo amante. Esta Medea limeña es un ejemplo de mujer despechada que recurre a la venganza para redimir la pérdida de su honra.

Otra tradición de Palma en la que unos subalternos encarnan varios pecados asociados con la marginalidad es "Matrícula de Colegio", incluida en Tradiciones en salsa verde. En ella se describen tres mellizos, hijos de un boticario italiano, que ingresan en una escuela y son interrogados por el director de su nueva escuela sobre su situación familiar. El docente describe a dos de los mellizos como "un par de maricones", y, a la hora de retratar al tercero, el lenguaje se vulgariza aún más, ya que el niño confiesa: "yo mamaba el pájaro de mi padre" (65-66). Como exploraremos en la sección 4.5 (dedicada la homosexualidad en la obra de Palma), el tercer mellizo sugiere que mantiene relaciones incestuosas con su progenitor, condenando no sólo la pedofilia, sino también la 
homosexualidad de padre e hijo. Esta unión entre diversos individuos marginales pone además énfasis en el resultado monstruoso que se produce cuando estos se agrupan. Por un lado, tenemos a un inmigrante italiano, posiblemente analfabeto y pobre, que se casa con "una robusta hembra chumbivilcana" (65). Chumbivilcas, una provincia andina del sur del Perú, es considerada una de las zonas más pobres del país y su población es principalmente indígena, por lo que podemos asumir que se trata de una mujer nativa. Asimismo, se describe como "robusta", masculinizando la indígena y haciendo alusión a su supuesta naturaleza fuerte y apta sólo para el trabajo manual. De esta unión reprobada nacen hijos "afeminados" y se propician relaciones incestuosas. Por lo tanto, la familia engloba numerosos representantes de la alteridad incluyendo al Otro racial, que, en este caso, también es una mujer, el extranjero, y los homosexuales (o sodomitas) responsables o víctimas del incesto y la pedofilia.

Finalmente, en "Matrícula" el autor hace hincapié en la educación de los niños, una actitud reforzada por el hecho de encontrarse en un ambiente académico en el que se descubren todas las carencias educativas de los niños mestizos. El director queda estupefacto ante tales revelaciones, poniendo de manifiesto que todo es resultado de dos componentes presentes en los muchachos: la "naturaleza" y la "crianza" (nature y nurture en inglés). Se culpabiliza a los progenitores de los pequeños por su crianza y alimentación que los induce a la sodomía y al incesto, pero el potencial ya está dentro de ellos: son el producto de una desaprobada mezcla racial y cultural, portadores de esa "mancha monstruosa". De este modo, se insiste en la necesidad de la educación para impedir que tales actos se lleven a cabo. Si el inculto extranjero no se hubiese casado con una mujer igualmente iletrada, se hubiese evitado el temido resultado. La unión entre los 
dos Otros es una lacra social que se traduce en la proliferación de una abundante descendencia moralmente deshonrada y físicamente inepta. Este hecho sería fácil de evitar mediante el control del cuerpo femenino.

4.5. "Marimachos" y "maricones": homosexualidad y Otredad de genero

Los homosexuales, al igual que la mujer, pueden considerarse Otros nacionales; es decir, subalternos marginales dentro de una nación. Sin embargo, al igual que en otros casos, pueden ser portadores de distintos rasgos asociados con la marginalidad, como la pobreza, la negritud o la condición de extranjeros. En cualquier caso, son a menudo juzgados como una influencia perniciosa dentro de la sociedad. Los conceptos de "homosexualidad" y "heterosexualidad" son de uso relativamente reciente. Los términos son popularizados en 1868 por el periodista austriaco Karoly Maria Kertbeny, activista y partidario de los derechos de los homosexuales (Edsall 3). Indudablemente, la homosexualidad no es un fenómeno desconocido hasta esa fecha, pero desde finales del XIX su definición toma un matiz muy distinto en el mundo occidental. En épocas anteriores, las relaciones entre personas del mismo sexo se denominaban "sodomía", un término de amplio espectro que también designaba el bestialismo (o zoofilia) y los actos carnales con mujeres cuyo fin no fuera la procreación (3). Por lo tanto, el sodomita se define por sus acciones, mientras que el homosexual se distingue por sus inclinaciones sexuales, sin necesidad de llegar a la consumación (3-4). Michel Foucault, en el primer volumen de Historia de la sexualidad (1976) especifica que la sodomía se percibía como una aberración puntual o transitoria, mientras que el homosexual se considera una "nueva especie", una "androginia del alma" (History 43). 
En la Lima decimonónica, apelativos como "maricón” y "marimacho" son epítetos comunes para designar a las personas que adoptan actitudes o semblantes asociados con el sexo opuesto. Al igual que el travestismo, estas actitudes son fuertemente censurados por la sociedad de la época. Tal como nos recuerda Oscar Pamo, “[a]unque la práctica homosexual se pierde en los orígenes de la humanidad, la identidad homosexual fue tomando forma desde los siglos XVII y XVIII cuando los médicos fueron consultados por los jueces para pronunciarse sobre problemas derivados de individuos con ese comportamiento" (31). Asimismo, Begoña Enguix (citando a David Greenberg) indica que en esta época la homosexualidad es descrita como una enfermedad, una afirmación crucial para terminar de definir al individuo como un Otro:

Durante el siglo XIX, y como resultado de un largo proceso histórico de categorización, a la edad, el sexo, la clase y el estatus de las personas, se suma la orientación sexual como mecanismo de diferenciación social. En un contexto marcado por el ascenso de la burguesía y el afianzamiento de la revolución industrial que la convirtió en clase dominante, se consolida la construcción de la categoría de desviado como un mecanismo funcional para el mantenimiento del poder en manos de una clase dominante. La medicina se erige en sucesora de la ideología religiosa y la desviación es explicada en términos médicos ... Hacia mediados del siglo XIX, la homosexualidad ya está bien caracterizada como enfermedad... (n.p.) 
Por lo tanto, en la época de Palma nos hallamos en pleno debate de la cuestión homosexual, ya que el siglo XIX es un momento de inflexión en su definición. La homosexualidad se interpreta como una condición médica en concordancia con las corrientes intelectuales decimonónicas que se muestran cada vez más proclives hacia las observaciones y categorizaciones científicas.

Existen varios ejemplos en los que se aprecia la preocupación sobre la homosexualidad en el Perú de los siglos XVIII y XIX. Destaca la Carta sobre los maricones publicada en el Mercurio Peruano (tomo 3, n. 94, 27 nov. 1791), escrita de manera anónima por un autor que utiliza el seudónimo Filaletes y está supuestamente dirigida a su amigo Leandro (Pamo 33). La carta es una crítica de Lima, apodada Androginópolis, y la presencia de hombres que imitan a las mujeres, tanto en su actitud como en su vestuario (33). Otro ejemplo es la Disertación en que se trata si una mujer se puede convertir en hombre, publicada en 1792 por el profesor de cirugía José Torpas de Ganarrila. El médico afirma que la posibilidad del cambio de sexo es un tema que "empezó á tomar mucho vuelo" un mes antes, ya que existía el rumor de que una monja se había convertido en varón en circunstancias misteriosas (Fuentes y Bailly, Biblioteca 2-3). Torpas concluye que, aunque existen mujeres que pueden tener atributos masculinos, víctimas de "un irregular desvió de la naturaleza", si la monja en cuestión no tiene tales rasgos "no hay fundamento suficiente para reputarla hombre" (13-15).

En cuanto a la cuestión homosexual, el folleto de autor anónimo El Paseo de Amancaes y Prisión de los Maricones (Imprenta Republicana de J. M. Concha, ca.1827), es una publicación escrita en verso que hace una crítica satírica tanto de la homosexualidad como de la sociedad limeña (Pamo 26-27). La obra es protagonizada por 
un viejo sacristán, un joven homosexual que quiere arrepentirse y unirse al clero y un grupo de travestis irredentos que se organizan para ir juntos a una romería en las afueras de Lima (Alegre 212). Lo interesante de este poema es que revela la visibilidad del colectivo homosexual en el espacio urbano de Lima (216). Asimismo, el relato breve “Lorenzita", de Manuel Atanasio Fuentes, publicado en La Broma (n² 26, 13 abril, 1878), ejemplifica la actitud de la época hacia los homosexuales. El/La protagonista, cuyo nombre es Lorenzo, pero es apodado/a Lorenzita, es un personaje descrito desde una perspectiva clínica como una “indecisión de la naturaleza” (Soto 78, 79). El autor, médico de profesión, declara que su dolencia es doble, ya que padece tanto de disentería como de un "afeminamiento" que debilita su cuerpo y, finalmente, contribuye en su prematura muerte (78).

A pesar de la presencia y visibilidad de este colectivo en los siglos XVIII y XIX, en la obra palmina los "hombres" homosexuales quedan silenciados casi por completo. El autor parece evitar este tema por lo que tan sólo aflora alguna fugaz mención. Este es el caso de la tradición ya mencionada "Matrícula de Colegio" (en Tradiciones en salsa verde), en la que tres niños mellizos son interrogados por el director de su nueva escuela. El tono de la conversación entre los jóvenes y el docente es perturbador para un lector hodierno:

— ¿Cuál es tu nombre? - preguntó don Pedro a uno de los chicos.

— Servidor de usted, señor maestro, Benedicto -contestó el interrogado con voz de flautín, anacrónica en ser tan desarrollado y vigoroso. 
—Vaya una vocesita para meliflua -musitó el magíster-, y tú, ¿qué nombre llevas? -continuó, dirigiéndose al otro.

—Para servir a Dios y a la Patria, me llamo Bartolomé-con idéntica voz atiplada.

—... ¡Vaya un par de maricones! ¡Lucido está el bachicha con su prole! ¿Y tú? preguntó, dirigiéndose al tercero.

— ¿Yo?, yo soy Crispín Gatiessa -contestó con voz de trueno, el muchacho. ...

— ¡Para la puta que los parió! ¡Qué cosa! ¿En qué consistirá, que siendo estos tres niños tan iguales de figura, nacidos del mismo vientre, de la misma ventegrada, o en el mismo día, uno discrepe tanto por vocerrón? ... ¡Vaya con los caprichos de la naturaleza!

—Yo le diré a usted, señor maestro, como mi madre no tiene sino dos tetas, ésas sirvieron para que estos dos hermanos mamasen a boca que quieres, y por eso han salido así... pobrecitos de voz.

—Y tú, ¿qué teta mamaste?

—... yo mamaba el pájaro de mi padre... y por eso he sacado este vocejón. (65-

Tal como se ha mencionado, esta tradición describe a distintos Otros unidos en una sola familia: el extranjero pobre, la mujer indoperuana y los niños "afeminados". Esta es quizás la única tradición de Palma en la que se hace una referencia tan explícita a la homosexualidad mediante la frase despectiva "¡Vaya un par de maricones!”. Asimismo, los muchachos son portadores de un amplio abanico de estereotipos tradicionalmente asociados con la homosexualidad, como es el caso de la "voz de 
flautín". Con estas palabras, el autor hace referencia al afeminamiento y cobardía que, según él, contrasta con su semblante robusto, ya que la masculinidad se considera incompatible con la homosexualidad. Esto puede interpretarse como un síntoma de la ansiedad hacia la posibilidad de que una homosexualidad latente y amenazadora se esconda tras los rostros menos sospechados, como es el caso del tercer niño, con voz y apariencia robusta, pero quien confiesa su costumbre de tener encuentros sexuales con su propio padre. Esto asocia a estos Otros con más estereotipos, ya que se sugiere una conexión entre el incesto, la pedofilia y la homosexualidad. Es decir, aquí las descripciones de las relaciones entre personas del mismo sexo se acercan al tradicional concepto de sodomía, representándose como actos aberrantes, “caprichos de la naturaleza". El estupor del docente recalca la ambigüedad a la hora de explicar el origen de la homosexualidad como producto de la "naturaleza" o la "crianza". Por una parte, aunque en un primer momento la tradición nos induce a pensar que sólo dos de los tres muchachos son "maricones", en la conclusión vemos que también el tercero lo es, por lo que parece sugerir que la homosexualidad está en la naturaleza de los niños desde su nacimiento. Por otra parte, se culpabiliza a sus progenitores por su crianza y alimentación. De este modo, la homosexualidad se convierte en producto de un estilo de vida, en una elección consciente y deliberadamente degenerada.

Aunque la figura del "hombre afeminado" no está muy presente en la obra de Palma, las mujeres denominadas por el autor "marimachos" o "mujeres-hombre" tienen más protagonismo. Estos personajes no son necesariamente descritos en términos de homosexualidad tal como la entendemos actualmente, sino que se ajustan más al concepto de sodomía, puesto que las mujeres deciden llevar a cabo actos censurados para 
su sexo como el travestismo, la negligencia de sus deberes familiares, el rechazo hacia la procreación, o la incursión en el espacio público y político del hombre. Este es el caso de las protagonistas de tradiciones como “ ¡A iglesia me llamo!” (tercera serie), “Mujerhombre" (séptima serie), "Juana la marimacho" (quinta serie), o "La Protectora y la Libertadora" (séptima serie).

"Juana la marimacho" narra la historia de la capeadora Juana Breña, cuyo cometido era el de montar a caballo y distraer a los toros con una capa en las corridas. En el nacimiento de Juana, "la naturaleza... [e]quivocó el sexo", y, “[b]ajo las redondas y vigorosas formas de la gallarda mulata, escondió las más varoniles inclinaciones" (n.p.). Por tales razones, Juana se convirtió en una paria social y las demás “mujeres, cuya sociedad esquivaba, la bautizaron (no sin razón) con el apodo de la Marimacho" (n.p.). Cabe subrayar el hecho de que Juana no sólo tiene "varoniles inclinaciones" sino que también es una mulata, hecho que la aparta aún más hacia los márgenes sociales. Asimismo, una vez más, se culpa a la naturaleza por dar pie a esta equivocación. Por otra parte, cuando Palma especifica las razones que la convierten en marimacho, en ningún momento alude a la homosexualidad de Juana. El pecado de la joven es principalmente el de irrumpir en el espacio público masculino, ya que, además de ser capeadora, tenía una actitud tradicionalmente asociada con los varones: “Juana Breña manejaba los dados sobre el tapete verde con todo el aplomo de un tahur; y puñal en mano se batía como cualquier guapo, que era diestra esgrimidora. En dos o tres ocasiones estuvo en la cárcel por pendenciera; pero, contando con valedores de alta influencia, lograba siempre su libertad" (n.p.). La joven, por lo tanto, lleva a cabo actividades que no son "propias" de su sexo e incluso se apodera del espacio político del hombre ya que cuenta con 
"valedores de alta influencia", que la convierten en miembro de una red social vedada para las mujeres.

Paradójicamente, en cuanto a su aspecto físico se hace hincapié en el hecho de que Juana es "una real moza" mulata y que "al verla sentían los hombres tentaciones... de reivindicarla" (n.p.). Al igual que otras mujeres subalternas, en ocasiones, la mulata vestida de hombre es doblemente sexualizada, $y$, en este caso, se hace referencia al amenazador entorno en el que los hombres quieren "reivindicarla". De esta manera, se insinúa el intento de doblegar a Juana, obligarla a ser mujer y actuar como tal, o incluso de forzar un encuentro sexual con la joven. Los atuendos y el comportamiento de Juana parece incitar a los hombres y darles licencia para actuar. Incluso las mujeres de su entorno la evitan y hablan a sus espaldas, mientras que su padre la sermonea diciéndole “¡Juana, no te metas a hombre!”, reprendiendo su intento deliberado de romper la división entre sexos. Sin embargo, el que finalmente castiga los actos de Juana es un toro, que la embiste haciendo que salga viva de milagro y que la joven decida cambiar su profesión convirtiéndose en carnicera. Por lo tanto, parece que la Providencia se encarga de poner a Juana en su lugar, castigándola por actuar como un hombre. En una condición similar a la de Juana, también hallamos a Manuela Sáenz, una de las protagonistas de "La Protectora y la Libertadora" (séptima serie) (véase sección 4.1). Manuela es "una equivocación de la naturaleza", que "encarnó espíritu y aspiraciones varoniles", por lo que, al igual que Juana, parece invadir el espacio político del hombre (n.p.). Asimismo, no mantiene relaciones homosexuales, pero es descrita por el autor como una mujer que "renunciaba a su sexo", una "mujer-hombre" (n.p.). 
Otra mujer que adopta el atuendo masculino se cita en la tradición “¡A iglesia me 1lamo!" (tercera serie). En el relato, Palma habla de una figura histórica de la época colonial, doña Catalina de Erauzo: "el alférez don Antonio de Erauzo era una mujer, a la que sus padres dieron el nombre de Catalina Erauzo y la historia llama la monja alférez" (n.p.). De esta mujer se dice que "murió, en un pueblo de Méjico, de más de setenta años de edad; que no abandonó el vestido de hombre y que no pecó nunca contra la castidad, bien que fingiéndose varón engatusó con carantoñas y chicoleos a más de tres doncellas, dándoles palabra de casamiento y poniendo tierra de por medio o llamándose Andana en el lance de cumplir lo prometido" (n.p.). ${ }^{36}$ En las Tradiciones, Palma sugiere que la situación de la monja alférez es en cierta medida habitual, puesto que también en la tradición "Mujer-hombre" (séptima serie) el autor afirma que en 1803 se descubre que "un caballero, conocido en Buenos Aires y en Potosí con el nombre de don Antonio Ita, no era tal varón con derecho de varonía, si no doña María Leocadia Álvarez, monja clarisa del monasterio de la villa de Agreda, en España" (n.p.). Un ignaro capellán, casó a Ita con Martina Bilbao, "mestiza de vida pecaminosa", quien conocía su condición antes de la boda (n.p.). En esta tradición nos hallamos frente a una posible relación homosexual entre dos mujeres. Sin embargo, los sentimientos de Martina se ponen en entredicho, ya que esta traiciona a Ita, denunciándola a las autoridades para irse con "un marido a la de veras" (n.p.). Finalmente, el enredo se resuelve con la confesión de Ita, quien admite ser María Leocadia Álvarez, una monja fugada, por lo que es devuelta a su convento en España. Su castigo es suave comparado con el de Martina, ya que su nuevo marido la

36 "Llamarse andana" es una frase coloquial que significa "[d]esentenderse de lo que es o podría ser un compromiso" (Real Academia). 
mata a golpes. Aquí la trama se muestra más despiadada con la mulata, un castigo ejemplar para una persona que secundó los deseos "antinaturales" de la "mujer-hombre".

Es llamativo el hecho de que en "Juana la marimacho" y "La Protectora y la Libertadora" se describen a "mujeres-hombre" que no parecen sentirse atraídas hacia otras mujeres. Asimismo, en “¡A iglesia me llamo!” se menciona de manera contradictoria que la monja alférez sedujo "a más de tres doncellas" pero "no pecó nunca contra la castidad". Finalmente, en "Mujer-hombre”, Palma afirma que Ita se casó con una mujer y que tuvieron más de "cinco años de fingido y pacífico connubio", pero no se alude a la consumación de dicho matrimonio descrito como "fingido" (n.p.). Además, se afirma que su esposa termina fugándose con "un marido a la de veras". Es posible que Palma crea que las relaciones homosexuales no se llegaron a consumar, pero también podría darse el caso de que el autor no crea que los encuentros sexuales entre mujeres puedan existir de manera efectiva.

En conclusión, podemos argumentar que la otredad sexual o de género tiene una fuerte presencia en los discursos decimonónicos. En la obra de Palma emergen abundantes descripciones sobre mujeres, homosexuales, prostitutas, mujeres racializadas u otros subalternos relacionados con los márgenes sociales. En ocasiones, la mujer se representa como el "ángel de la casa", abnegada, dócil y cuidadora de la familia, un modelo de conducta para todas las mujeres. En otras circunstancias, las mujeres (especialmente las criollas) son ejemplo de picardía e inteligencia y símbolo de una exuberante nación en camino hacia la modernidad pero también anclada en el pasado y el atraso. Por último, la mujer también puede ser un peligro para la sociedad ya que su rol de subalterno puede amenazar los equilibrios de poder al pretender desligarse de su 
posición social o facilitar la movilidad social de otros subalternos como los Otros raciales. Por otro lado, en las sociedades latinoamericanas el siglo XIX marca el comienzo del acercamiento de la mujer hacia ciertos aspectos de la modernidad. A finales de siglo, adopta paulatinamente nuevos roles sociales y, desligándose de su tradicional reclusión doméstica, empieza a abrirse paso hacia la esfera pública, adoptando incluso roles laborales anteriormente reservados para los hombres. Su relación con lo sagrado se rompe parcialmente, adentrándose en el terreno secular. Ante este proceso de cambio, en el que chocan tradición y modernidad, en la obra de Palma surgen descripciones ambiguas de la mujer. Por un lado, el autor describe con nostalgia las mujeres del pasado, sus sayas y sus mantos, mostrando un visible temor hacia los intentos de ruptura de los roles sociales marcados por el patriarcado. Por otro, representa con excitación a las osadas mujeres de su periodo, deseables y al mismo tiempo provocativamente peligrosas. Asimismo, asoma cierto temor hacia un mundo crecientemente moderno y liberal, en el que las líneas divisorias entre clases, géneros y razas se desdibujan cada vez más. Las mujeres se describen en cuanto a su relación con diversos Otros, como los homosexuales y los Otros raciales. La ideología de Palma, producto de la mentalidad científica del periodo, revela la necesidad de mantener una clara distinción entre esas categorías y las relaciones de poder en la sociedad. El control de la mujer en un ámbito privado es imprescindible para evitar la degeneración social como el declive de la raza (el mestizaje). Este pensamiento se refleja en su obra en la que tanto los Otros de género como todos los grupos sociales que deciden apartarse de los roles socialmente asociados con ellos son castigados por la trama. 
5. "Mestizo educado, diablo encarnado": mezclas raciales en Ricardo Palma

Mulato, mestizo o cholo, zambo, pardo, trigueño o criollo son sólo algunos de los términos comúnmente utilizados para definir lo indefinible, clasificar lo inclasificable. El amplio espectro en el que se encuentra la gran diversidad fenotípica del ser humano pone de manifiesto la inviabilidad de determinar los rasgos de cada grupo humano, o lo que llamamos "razas". El mismo concepto de "hibridez" es problemático, puesto que presupone la existencia de unas "categorías esenciales" previas, estables y puras, que no tiene base científica (Gruzinski en López Beltrán 292). Sin embargo, estas generalizaciones son inamovibles en el pensamiento humano y su necesidad de clasificar, especialmente en la ideología decimonónica anclada en la era de los descubrimientos científicos. En el contexto peruano, adquiere especial relevancia la perspectiva de Ricardo Palma, en cuya obra mestizos, mulatos o los llamados pardos (como el mismo autor) parecen luchar para trascender sus limitaciones sociales y étnicas, creando una nueva serie de identidades basadas en modelos nacionales idealizados. ${ }^{37}$ A pesar de la etnia de Palma, la numerosísima población no blanca peruana, no tiene un protagonismo marcado en su obra, un acto inconsciente o deliberado que, sin embargo, puede revelar la situación social de estos colectivos: centrales y activos en la vida política y social peruana, pero circunspectos en cuanto a sus identidades étnicas.

\footnotetext{
${ }^{37}$ Véase también la obra poética de José Santos Chocano (1875-1934), quien utiliza el mestizaje americano como tema de su producción literaria.
} 


\subsection{Castas, limpieza de sangre y gracias al sacar}

Los primeros contactos entre europeos y otros grupos étnicos en la Colonia dan pie a un mestizaje a gran escala, un fenómeno que desestabiliza y desbarata las estáticas creencias europeas sobre las razas. Recordemos asimismo que el germen del racismo tal como lo conocemos hoy en día toma forma en la era del imperialismo europeo y responde a un fin meramente económico. Desde la perspectiva del Viejo Continente, afrodescendientes e indios son fáciles de etiquetar ontológicamente y separar de los europeos; tal categorización tiene el propósito de distanciar los subalternos no sólo de los blancos, sino también de la humanidad, evidenciando su supuesto bestialismo y barbarie. Por otro lado, mestizos y mulatos desafían estas ideas preconcebidas, ya que su “ambigüedad fenotípica" los acerca peligrosamente a la de los conquistadores, y a sus derechos y privilegios. De esta indeterminación, surge la necesidad entre los colonos de separarse de otras etnias, controlando y definiendo su lugar en la sociedad, con el fin de justificar su explotación.

En la América colonial, surge así una estructura piramidal jerarquizada que pretende ordenar a los habitantes en castas, o grupos étnicos, conectando el color de la piel con su labor dentro de la sociedad. Carlos López-Beltrán precisa que la estructura ideológica de las castas es un concepto que nace, o se afianza, con la colonización americana y su propósito no es informativo; con su creación la única intención de los colonos es la de controlar y explotar a los subalternos (289-90). Aunque para finales del siglo XIX la división de castas ya no tiene efectos prácticos, las clasificaciones coloniales siguen presentes en la ideología decimonónica. En este contexto, destacan las descripciones de mestizos, descendientes de un progenitor blanco y otro indígena; 
mulatos, hijos de un padre afroamericano y otro blanco; zambos, descendientes de afroamericanos e indígenas; y pardos, fruto de la unión trirracial entre afroamericanos, blancos e indígenas, como es el caso de Ricardo Palma. Tales definiciones se complican al añadir el término criollo, que puede englobar a los descendientes de los colonos blancos y, al mismo tiempo, diferenciarlos de los europeos. Cada casta tiene una serie de derechos u obligaciones ineludibles y se desalientan, o incluso persiguen, los enlaces entre castas (a excepción de los comienzos de la Colonia, cuando la Corona española fomenta los matrimonios entre miembros de la nobleza inca y los conquistadores). Palma se hace eco de esta situación en su tradición "Bolívar y el cronista Calancha" (cuarta serie) al mencionar un bando real de 1706 sobre la distribución de los trabajos en el Nuevo Mundo:

$[\mathrm{L}] \mathrm{a}$ política colonial supo poner raya divisoria entre conquistadores y conquistados, ... para probarlo me bastará citar el bando que en 17 de julio de 1706 hizo promulgar la Real Audiencia disponiendo que ningún indio, mestizo, ni hombre alguno que no fuera español, pudiese traficar, tener tienda, ni vender géneros por las calles, ... debiendo ... ocuparse sólo de oficios mecánicos. (n.p.)

Tal como indica Palma, tanto la clase alta como la clase media emprendedora estaban compuestas casi exclusivamente por blancos de origen europeo, mientras que los criollos tenían acceso a la riqueza con un menor grado de privilegios. Por consiguiente, los colectivos más numerosos quedaban arrinconados en la parte más baja de la pirámide social, compuesta por mestizos, mulatos, indígenas y, sobre todo, esclavos 
afrodescendientes. Estos tenían restricciones y obligaciones en todos los aspectos de sus vidas, desde los trabajos a los que se podían dedicar hasta la regulación de su vestuario. Existen testimonios fechados 1571, en lo que los oficiales coloniales se pronuncian contra el hecho de que mujeres negras, esclavas o libres, puedan llevar ropa o hoyas, reservadas a las europeas o las mujeres casadas con españoles (Twinam, Purchasing 89).

Entre las causas del mestizaje podemos subrayar las nuevas condiciones sociales propiciadas por las Colonias, en las que se marginaliza y subyuga la población indígena y aumenta la inmigración, tanto voluntaria, en el caso de los europeos, como involuntaria, con la esclavización de los africanos (López-Beltrán 291-92). El desequilibrio de género es un ulterior factor que propicia el mestizaje, ya que los colonos blancos son varones en su mayoría, favoreciendo las uniones con mujeres indígenas, a menudo en contra de la voluntad de estas últimas (291-92). Según López-Beltrán, el sistema de castas tiene dos funciones. La primera es descriptiva, por lo que se crean esquemas de definición de las distintas mezclas raciales; y la segunda es normativa, ya que se propician las uniones entre personas de igual o superior casta con el objetivo de "blanquear" o "purificar" sus integrantes y alcanzar las idealizadas cualidades de los blancos europeos (293).

Cabe destacar el paralelismo entre las castas y otra manera de describir el orden jerárquico: la "clase" (Twinam, Purchasing 48). Esta categorización no es equivalente a la de casta, ya que no denota necesariamente el nivel socioeconómico o el color de la piel de sus integrantes; no obstante, en ocasiones se usa indistintamente para medir el estatus social, el patrimonio o la etnia de las personas (48). En las Tradiciones de Palma, podemos observar cómo el concepto de linaje se mezcla con el de clase en sus múltiples menciones de personas con "ascendencias de sangre azul". Asimismo, en los orígenes del 
fenómeno de las castas se halla una serie de preocupaciones de los colonizadores ya presentes en el Viejo Continente. La presencia de otras etnias amenaza "debilitar" la raza blanca y su "limpieza de sangre" (el hecho de no tener antepasados musulmanes o judíos), pero también entran en juego conceptos como la ilegitimidad, el afeminamiento o la degeneración física, que amenazan la descendencia de los colonos en su contacto con otras etnias y condiciones climáticas (López-Beltrán 301-02). Palma menciona la correlación entre limpieza de sangre y clase social al describir uno de los protagonistas de sus Tradiciones, el asturiano D. Fernando de Abascal, "un hidalgo segundón, sin más bienes que su gallarda figura y una rancia ejecutoria que probaba siete ascendencias de sangre azul, sin mezcla de moro ni judío" (“¡Fortuna te dé dios!”, segunda serie, n.p.). El concepto de limpieza de sangre se asocia sobre todo con la idea de "sangre azul" y se menciona en las Tradiciones, aunque no se describe como una cualidad innata, sagrada o divina en el ser humano. Palma afirma que "el expediente sobre limpieza de sangre" es fácil de conseguir para los que nacen siendo nobles, ya que estos, aunque sean pobres, "salen del limbo materno con un Don tamañazo en mitad de la frente. ("El conde de la Topada", séptima serie, n.p.). Con tono abiertamente sarcástico, Palma no deja de recordarnos que el hecho de tener la "sangre limpia" no otorga cualidades superiores o una mejor situación económica, poniendo en ridículo una tradición colonial desde cuya perspectiva el autor quedaría excluido.

Por otra parte, en la Colonia el hecho de no tener limpieza de sangre ocasionalmente no era considerado irreversible. Las "gracias al sacar" son unos documentos que podían otorgar un blanqueamiento y limpieza de sangre simbólicos a aquellos que podían permitirse solicitarlos. Algunos mestizos, mulatos o pardos podían 
requerir esta documentación al gobierno central mediante un servicio pecuniario. Como hemos visto en el Capítulo 3, las gracias al sacar revelan que desde la Reconquista en España hasta el siglo XIX en América el concepto de limpieza de sangre tuvo gran relevancia y que existe una evidente conexión conceptual entre "raza" y religión. Desde este periodo, los decretos que castigan o limitan a los portadores de "sangre impura" empujan a los españoles a identificarse como grupo mediante ideas comunes de discriminación hacia el Otro (Twinam, Purchasing 51-52). En la Península, el objeto de exclusión es primariamente religioso, antes la presencia de judíos o "moros", pero en América esta convicción sigue muy viva y, cerca del cierre del periodo colonial, se traslada hacia el concepto de "raza" (51-52). En este sentido, Palma sugiere que el concepto de "pureza de sangre" en su acepción religiosa heredada de la Península está muy presente en las Colonias:

Doña Engracia pasaba sus horas en medio del lujo y el ocio, y no faltaron damas que sintiéndose humilladas se echaron a averiguar el abolengo de la orgullosa rival, y descubrieron que tenía sangre alpujarreña, que sus ascendientes eran moros conversos que alguno de ellos había vestido el sambenito de relapso. (“Doña Engracia en Toledo", primera serie)

De este modo, Palma no sólo descalifica la naturaleza o cultura de los españoles, sino que enfatiza la opulencia y ostentación de la protagonista, quien además tiene "sangre morisca" y, por lo tanto, su vanidad queda ridiculizada. 
Hasta bien avanzado el siglo XVIII, por lo general la palabra "raza" no se asocia por completo a una cuestión biológica, sino a un "defecto de linaje", es decir, los descendientes de los no católicos (Twinam, Purchasing 51-52). En el diccionario Tesoro de la lengua castellana o española (1611) de Sebastián de Covarrubias y Orozco, en la voz de "casta" se afirma que de trata del "linaje noble y castizo, el que es de buena línea y decendencia; no embargante que dezimos es de buena casta, y mala casta” (n.p.). Asimismo, en la definición de "limpio" establece que "limpio se dice comúnmente el hombre cristiano viejo, sin raza de moro ni judío" (n.p.). Finalmente, define "raza" como "la casta de los caballos pura sangre, marcados con un hierro para reconocerlos como tales... en los linajes se toma en mala parte, como tener alguna raza de moro o judío" (n.p.). Tal como afirma Walter Mignolo, los animales eran clasificados considerando su “raza", mientras que las personas se distinguían por su "etnia" o nacionalidad, al llamarlos, por ejemplo, españoles o portugueses (317). El uso del término "raza" para describir a judíos y moros, o "sangre", para hablar de personas de otra religión, hace que las nociones de "raza", etnia y religión, se mezclen, implantando la semilla del racismo como clasificación jerárquica de personas (317).

Entre los siglos XVIII y XIX los conceptos se reformulan, por lo que el color de la piel empieza a reemplazar a la sangre como marca racial (Twinam, Purchasing 33031). Asimismo, Palma pone en evidencia la conexión entre la limpieza de sangre y varias cuestiones asociadas al linaje, como es el caso de la ilegitimidad. En su tradición "Un libro condenado", Palma menciona un libro que sale a la luz con varios secretos sobre ciertas familias de la élite: 
las familias de Lima andaban más alborotadas que gallinero de aldea con zorro a la vista; pues no pocas de ellas aparecían vulneradas con barras de bastardía, villano abolengo o cualquiera otra mácula de poca limpieza de sangre. Esto era gordo, muy gordo, en tiempos en que la sangre de la mayoría de los limeños no era roja o plebeya como hogaño, sino de añil subido. (Séptima serie, n.p.)

El "racismo", por lo tanto, no nace como resultado de la discriminación hacia la sangre o el color de la piel, sino como una clasificación discursiva que empezó a gestarse en la creación de los imperios coloniales, modernos, o proto capitalistas (Mignolo 317). El concepto de limpieza de sangre se infiltró de este modo en varios discursos de discriminación y marginalización presentes hasta el día de hoy.

A pesar del abierto rechazo de Palma hacia el concepto de limpieza de sangre, Gonzalo Portocarrero pone en muestra el conflicto identitario del autor ilustrando su propósito de "blanquearse", plasmado en las fotografías y los retratos de Palma (Urgencia n.p.). Este conflicto identitario no se convierte, sin embargo, en un completo rechazo hacia las mezclas raciales con las que el autor comparte numerosos rasgos, sino en una negociación con el lector para establecer el lugar de estas comunidades dentro de la sociedad limeña. En ocasiones hace concesiones en las que admite los "males" de sus semejantes y traza un paralelismo que los identifica con los subalternos, como indios y negros, mientras que en otros escenarios los justifica haciendo referencia a los siglos de represión y exclusión padecidos por estos. Asimismo, en ocasiones Palma introduce a sus indios en el marco de un pasado incaico mítico e idealizado, permitiendo que estos cobren un protagonismo marginal y nostálgico. 
Sin embargo, la actitud de inclusión de Palma no siempre fue compartida por sus contemporáneos o sucesores. Como descendiente de una familia multiétnica, Clemente Palma, hijo de Ricardo Palma, hereda el complejo identitario del padre llevando el rechazo hacia los subalternos a un nivel extremo en su tesis racista El porvenir de las razas en el Perú (1897). Por una parte, el ensayo defiende la creencia ampliamente aceptada en Latinoamérica de que es posible mejorar o "blanquear" las "razas" inferiores, haciendo que estas se mezclen con otras superiores, es decir, las de origen blanco europeo (264):

Cruzar las razas débiles con las fuertes, las razas artísticas con las razas prácticas, aniquilar con cruzamientos sucesivos los gérmenes de razas inferiores, sustituir glóbulos de sangre anémica y vieja, con los glóbulos de una sangre pletórica y sana; en una palabra, sostener la virilidad y salud del pueblo con una solicitud semejante a la de los ganaderos: vigilando y afanándose por la selección de las razas. (Palma, El porvenir 3)

De este modo, el blanqueamiento racial funcionaba de manera parecida a las "gracias al sacar" de la colonia. Mientras estos documentos facilitaban un "blanqueamiento legal" en la sociedad colonial, los cruces con los blancos europeos proporcionaban el deseado y quimérico blanqueamiento fenotípico que permitiría alcanzar el ideal blanco de manera definitiva. El ensayo de Clemente Palma cataloga meticulosamente las "razas" de su país, describiendo sus supuestos rasgos y, especialmente, sus defectos inherentes. Por ejemplo, afirma que la unión entre chinos e 
indios genera al híbrido más pernicioso, definido en las pinturas de castas de las Colonias como "salta atrás", un término despectivo que hace alusión a su supuesto rol en la degeneración de la raza. Para el escritor, la naturaleza se encarga de suprimir tal abominación ya que su descendencia queda infecunda o muere "antes de llegar a la virilidad" (Velázquez, Mirada 270). El argumento del autor deshumaniza a estos individuos, haciéndose eco de la creencia sobre el paralelismo entre estos y los mulos, unos animales híbridos y estériles que resultan del cruce entre una yegua y un asno. La comparación con este animal, fuerte y dócil, destinado únicamente a servir al hombre y al trabajo extenuante, asocia a los mulatos y a otros subalternos con la noción del bestialismo. Sin embargo, Clemente Palma considera la raza india tan "degenerada" y débil que está destinada a diluirse gradualmente debido al mestizaje. Finalmente, muestra un talante ambivalente hacia los criollos, un grupo étnico con el que él mismo pudo identificarse. Estos son retratados como los representantes de la modernidad peruana, bondadosos pero desordenados, pusilánimes pero apasionados, por lo que la afluencia de sangre germánica es considerada fundamental para "pulir" los últimos desperfectos de este colectivo y sustentar la mejora del país (Velázquez, Mirada 270).

López-Beltrán afirma que los integrantes de las castas no pueden autoreconocerse y formar identidades autónomas, puesto que son definidos como el resultado de sucesivas generaciones (289-90). Por consiguiente, la noción de casta está conectada con la de determinismo, la creencia de que existe un paralelismo entre los cuerpos y sus inclinaciones y propiedades (290). Tal como apunta López-Beltrán, la noción de casta representa la transición desde la otredad moral descrita por Montesquieu, hacia la fisiológica, que implanta la semilla del racialismo científico con lo que se "brutaliza" al 
Otro negando su humanidad (290). El racismo moderno es el fruto de la unión entre la ideología de pureza de sangre y la teoría hipocrático-galénica (290).

En el siglo XVIII, el sistema de castas se materializa visualmente por medio de cuadros o series de pinturas. En ellas se muestran retratos de personas o familias con hijos que residen en las colonias, incluyendo a afrodescendientes, indios, blancos, mestizos y mulatos, entre otros. Las pinturas son normalmente rotuladas y numeradas, especificando la "raza" de padres y descendientes, con enunciados que rezan, por ejemplo, "español e india producen mestizo", "negra y español producen mulatos", o "negro con mulata producen zambo". En ocasiones, las combinaciones empiezan retratando a castas "inferiores", como la de los afroamericanos, y conducen hasta una idealizada casta blanca (Twinam, Purchasing 49). Palma otorga gran importancia a la pintura, especialmente cuando su objeto de representación es de temática nacional o andina. El autor destaca, por ejemplo, el delicioso imaginario y los retratos de subalternos de los pintores del periodo en Ecuador:

... la escuela [pictórica] quiteña se hace notar por la viveza del colorido y la naturalidad. No busquéis en ella los refinamientos del arte, no pretendáis encontrar gran corrección en las líneas de sus Madonnas; pero si amáis lo poético como el cielo azul de nuestros valles, lo melancólicamente vago como el yaraví que nuestros indios cantan acompañados de las sentimentales armonías de la 
quena, contemplad en nuestros días las obras de Rafael Salas, Cadenas o Carrillo.

("El Cristo de la Agonía", primera serie n.p.) ${ }^{38}$

Este interés por la temática rural e indígena pudo formar parte del mismo imaginario en el que se inspiraron las pinturas de castas del periodo colonial. En el virreinato de Nueva España del siglo XVII, se han hallado numerosas pinturas de castas, mientras que en el Perú destacan los cuadros de mestizaje del virrey Amat, actualmente conservados en el Museo Nacional de Antropología de Madrid. ${ }^{39}$ Este conjunto de cuadros de mestizaje está compuesto por veinte lienzos que forman parte de una serie que retrata a los habitantes de la América colonial del área andina. Existe documentación sobre su procedencia y origen que prueba que es un encargo realizado por el virrey D. Manuel Amat y Junyent (1761-1776) en el Perú y “que debían remitirse a Madrid con destino al Gabinete de Historia Natural formado por el futuro Carlos IV" (Wuffarden 372-73). El propósito de estas obras era el de dar a conocer en Europa las mezclas raciales existentes en el virreinato.

Tanto en la temática como en los colores de las pinturas afloran los intereses coloniales que se hallan detrás de su comisión. En cuanto al uso cromático, la serie retrata a los indios y negros sin mezcla de manera visiblemente distinta a los blancos o españoles (Romero de Tejada n.p.). Como podemos observar en el cuadro de la serie del virrey

\footnotetext{
${ }^{38}$ El escritor peruano Mariano Melgar (1791-1815) integra en su obra ejemplos del yaraví, un género musical con temática indígena popularizado durante el virreinato peruano.

${ }^{39}$ Generalmente, los conjuntos de pinturas de castas mexicanas constaban de 16 lienzos organizadas en un orden concreto; la serie del virrey Amat es posiblemente la única que conste de 20 pinturas, distribuidas en distinto orden (Romero de Tejada, n.p.).
} 
Amat con título " $\mathrm{N}^{\circ}$ 8. Negros bozales de Guinea, Yden", resulta difícil distinguir el rostro de los guineanos de ropajes modestos y oscuros, situados frente a un sombrío fondo monocromático (n.p.). Si los observamos atentamente, su expresión muestra una mueca severa y rígida, o ausente y abatida. Por otra parte, el retrato contrasta con la pintura “ $\mathrm{N}^{\circ}$ 5. Español. Mestiza. Producen Quarterona de mestizo", en la que se muestran un español, una mestiza y su prole, una cuarterona, cuya sangre se "depura" parcialmente de rasgos no blancos, acercándose paulatinamente al ideal europeo. Los colores son visiblemente más vivaces, sus atuendos más modernos y su expresión más alegre y despreocupada (Romero de Tejada n.p.). Finalmente, en el cuadro " $N^{\circ}$ 15. Español. Gente Blanca. Quasi limpio de origen", los protagonistas son retratados sin prole, junto a un sirviente afroamericano. El propósito de este cuadro puede ser el de comparar a los sujetos retratados con los de otros óleos y su descendencia no necesita ser retratada, ya que su linaje blanco se considera innegable. En la mitad derecha, donde quedan sentados los españoles, los colores también son muy vivos y sus expresiones son apacibles y tranquilas (Romero de Tejada n.p.). Su vestimenta es la más lujosa de la serie, y destaca la predominancia de un rojo vivo, símbolo de poder y opulencia (n.p.).

Con este cambio gradual que pasa desde los colores apagados de los subalternos hasta los lujosos ropajes de la "gente blanca", el propósito de los cuadros parece ser el de enfatizar de manera subliminal "el carácter civilizador ejercido por la presencia peninsular en América" (Wuffarden 372-73). Puesto que fueron encargados por el virrey D. Manuel Amat y Junyent para un público europeo, es muy probable que tras su encargo se esconda un propósito propagandístico que justifique la empresa colonial americana. De este modo, el virrey pudo reafirmar su posición en la colonia, contribuir con la labor de 
atraer más inversión europea y sugerir la abundancia de mano de obra barata y dócil. Desde el punto de vista religioso y moral, su explotación queda además redimida porque la influencia social y biológica europea evangeliza, civiliza y "limpia" la sangre de los subalternos, creando a ciudadanos más blancos y felices. Es interesante observar además como el pintor especifica que la mujer retratada en el cuadro $\mathrm{N}^{\circ} 15$ es un ejemplo de individuo blanco "Quasi limpio de origen". En este sentido, es importante notar que la prole de cada matrimonio retratado se convierte en progenitor en el siguiente cuadro (Romero de Tejada n.p.). Puesto que el cuadro anterior se titula "No 14. Español. Requinterona de Mulato. Produce Gente blanca", queda claro que después de la pintura $\mathrm{N}^{\mathrm{o}} 15$, no cabe mejora posible, por lo que, aunque los blancos de América queden racialmente blanqueados y “mejorados”, estos no amenazarán la posición y el poder de los españoles, ya que su sangre nunca se considerará completamente limpia.

A pesar de su popularidad entre los colonos, a partir de finales del siglo XVII y comienzos del XVIII, los sistemas de castas se convierten en "un armazón ideológico sin conexión nítida ni con los cuerpos y modos físicos reales ni con las conductas y prácticas de la población" (López-Beltrán 302). A finales del siglo XVIII queda patente la inviabilidad de la labor de categorización de las infinitas mezclas raciales y, como sugería Humboldt, a principios de siglo decae "el gran interés de vanidad y aprecio público en valuar exactamente las fracciones de sangre europea que han cabido a cada cual en las diversas castas" (López-Beltrán 296; Aguirre Beltrán 169; Humboldt 90). Palma habla de los efectos de las creencias asociadas con las castas y la limpieza de sangre durante el virreinato en su tradición “iFeliz barbero!” (cuarta serie): 
En ningún pueblo del Perú, durante el gobierno monárquico, estuvo tan marcado como en Huánuco el prestigio de la aristocracia de sangre azul. La chusma, la muchitanga, el pueblo, en fin, se prosternaba ante los descendientes de los conquistadores que se avecindaron en la ciudad. Decir huanuqueño era lo mismo que decir noble a nativitate. En una palabra, sin tener una sagrada pena de Covadonga, eran los vizcaínos y asturianos de la América. (n.p.)

De este modo, Palma expresa su rechazo hacia estas antiguas creencias que dejan al autor inevitablemente fuera del hermético grupo elitista ocupado por blancos de origen europeo.

\subsection{Criollos}

Fruto de los enlaces entre hombres peninsulares y mujeres indias nobles, la mezcla racial tuvo sus orígenes en la escasez de mujeres españolas en los albores de la Colonia (Throp y Paredes 92). ${ }^{40}$ Palma corrobora el recelo hacia los blancos pobres europeos tras la independencia y menciona el concepto de casta en relación al nivel económico: "no saben qué casta de pájaro fue Perico Bustinza... era un mocetón andaluz que llegó al Cuzco hecho un pelaire, con una mano atrás y otra adelante, en busca de la madre gallega...” (“Quizá quiero, quizá no quiero”, cuarta serie, n.p.). Asimismo, menciona la practica colonial de unir en matrimonios a princesas indígenas con colonos europeos para afianzar su poder en el Nuevo Mundo, como es el caso de Perico Bustinza

\footnotetext{
${ }^{40}$ Véase el artículo de Francisco Martínez Hoyo, "La mirada del otro. Ricardo Palma y España” (2013).
} 
quien se casa "con la ñusta o princesa doña Beatriz Huayllas, hija del inca HuaynaCapac, matrimonio que dio al marido, aparte de las muchas riquezas de que era poseedora la mujer, gran influencia entre los caciques e indios del país" ("Quizá" n.p.). Tal practica era a menudo propiciada por los decretos enviados desde la corte:

... su majestad don Felipe II envió a estos sus reinos del Perú una real cédula, ordenando que las viudas ricas contrajesen nuevo lazo, sin excusa valedera en contra, con españoles escogidos entre los que más hubieran contribuido al restablecimiento del orden. Así creía el monarca no sólo premiar a sus súbditos, dándoles esposas acaudaladas, sino poner coto a nuevas rebeldías. ("Quizá” n.p.)

Más tarde, también se dieron numerosas uniones condenadas por las autoridades con mujeres de posición social inferior, cuya descendencia quedaba ligada a la comunidad materna por la falta de reconocimiento jurídico paterno (Throp y Paredes 92). Por otro lado, los descendientes criollos, mestizos o mulatos de los colonos ocupaban un lugar liminal: cerca del poder de los blancos, pero observados con recelos por estos $(92)^{41}$

Tras la Independencia, las etnias que se hallaban en los puestos más elevados de la jerarquía, los colonos blancos nacidos en España veían cómo sus posiciones eran desafiadas y amenazadas por las élites criollas, mientras que la infinita mezcla racial dificultaba aún más las tipificaciones étnicas. El uso de las palabras "español/a" o

${ }^{41}$ Véase el libro de James Lockhart, Spanish Peru, 1532-1560: A Social History (1968). 
"blanco/a" también era problemático ya que, mientras los americanos podían utilizarlos para describirse a sí mismos como descendientes de blancos o españoles, los peninsulares podían referirse exclusivamente a personas nacidas en suelo europeo (Twinam, Purchasing 48). El título de Don se otorgaba a "españoles blancos", aludiendo en este caso a todos aquellos americanos que fueran blancos (RC, Doc. 18, 1797 en Twinam, Purchasing 48).

En Latinoamérica, la redistribución del poder después de la Independencia hace que mestizos y mulatos burgueses puedan tener acceso paulatinamente a posiciones de poder. Sin embargo, lejos de enaltecer su etnia, esta aparece silenciada o asimilada dentro de un grupo "racial" indefinido, el de los criollos, representados en relación metonímica con las nuevas naciones. José Antonio Mazzotti nos recuerda que el término "criollo" alude más a una condición social y legal que a una condición biológica. Conforme avanza el virreinato, se va gestando una precaria identidad criolla en contraposición a la de los españoles peninsulares, pero esta no integra a sujetos subalternos (Mazzotti 11-13). En la República Peruana, las nuevas élites se postulan portadoras de (casi todos) los rasgos más valorados de distintas etnias, como vemos en obras como la de Clemente Palma, quien postula que "[c]on todos estos elementos étnicos se ha formado la raza criolla. Características que constituyen la tonalidad psíquica de esta raza mixta. - Bondad de genio (acción del medio.) - Espíritu artistico (acción de la raza española.)- Sensualidad (acción de las razas negra y española.) - Fanatismo (acción de las tres razas.)” (2). Según el autor, los individuos "racialmente mezclados" como los criollos, poseen la benevolencia atribuida a los nativos y las habilidades de los blancos europeos. Sin embargo, también se observa un posible conflicto identitario, ya que su "otredad interna", 
su "naturaleza" o "índole”, puede dar pie a su "fanatismo". Por consiguiente, el fervor excesivo puede propiciar la caída de los criollos hacia el extremo opuesto, pudiendo llegar a ser portadores de las peores cualidades de esas etnias, como el bestialismo de los subalternos y la crueldad despiadada de los europeos.

En su tradición "Un predicador de lujo" (primera serie) Ricardo Palma habla sobre el villorio de Huacho, antaño hogar de gente emprendedora, pero en declive en la época del autor. Ante tal situación, el narrador muestra su pesar al afirmar que “[d]ecididamente las razas degeneran" (n.p.). Aplicadas al contexto provinciano, las ideas sobre la existencia de una "raza degenerada" en Perú se refieren al conocido precepto de "mejorar la raza"; es decir, la práctica de evitar el mestizaje, impidiendo las uniones con subalternos y casándose con blancos con el fin de "blanquearse". Paradójicamente, aunque se considera que los rasgos de los seres humanos son "naturales" e inmutables, la "mejora racial" se torna posible cuando entra en escena la movilidad social y la mejora en la situación económica de las élites criollas (Oliart 265). Tal como podemos observar en tradiciones como "San Antonio de Montesclaros" (cuarta serie), protagonizada por don Ireneo Villena y Gorrochátogui, un despótico vizcaíno que maltrata a los indígenas, los blancos europeos (o de ascendencia europea), ocupan un espacio ambiguo en el universo de Palma. Puesto que durante la Colonia estos se hallaban en el punto más elevado del escalafón social, con la independencia se enfrentan a la hostilidad que surge en el proceso de renegociación de la posición de las nuevas élites formadas por criollos, mulatos o mestizos. Palma insiste en la necesidad de un gobierno nacional criollo, mucho más equilibrado y benevolente que el de la Corona. Por otro lado, al igual que sus 
compatriotas no incluye a afroperuanos o a indígenas entre las clases dirigentes, sucumbiendo al ideal de "blanqueamiento" social.

\subsection{Mulatos}

En la obra de Palma, los términos "mulato" y "mulata", por lo general, no se asocian con conceptos abiertamente despectivos; sin embargo, autores decimonónicos, como Felipe Pardo y Aliaga (1896-68), cuyos ensayos se mencionan en las Tradiciones de Palma, muestran el sentimiento extranjerizante y anticriollista de las élites peruanas, así como el antagonismo hacia los subalternos y las mezclas raciales. Podemos observar el recelo ante la infiltración de los mulatos en la aristocracia en el "Prólogo" que Pardo y Aliaga escribe para su revista Espejo de mi Tierra (1840), donde narra una breve anécdota sobre una mulata lavandera:

A propósito de empleomanía: van Ustedes á ver lo que le sucedió en años pasados á un amigo mío, ... dijo á su lavandera, ¿quieres que me lleve á tu hijo? ... nuestro diplomático tendría la mira de hacer de él un buen criado, que, si se quiere, llegara hasta la jerarquía de ayuda de cámara. La mulata dio unos cuantos pliegues al hocico, como quien medita. Veia en su pimpollo uno de aquellos injertos de nuestras castas, fruto de amores heterojeneos, ... en suma, una de aquellas medias tintas, que siendo para destinos bajos claras, y oscuras para altos

puestos, ... [y que] merece el celo paternal de las autoridades de policia. ... la lavandera rumiaba la propuesta; y prorrumpió al fin en un suspiro, y en la 
siguiente pregunta: ¿Y qué empleo yevadá mi Manongo? El diplomático, para ahorrar cuestiones, le ofreció la secretaria de la legación. (324)

Pardo y Aliaga pone de manifiesto el temor ante la infiltración de mulatos entre las élites, especialmente cuando se trata de cargos políticos o de liderazgo. Las descripciones de los dos mulatos, apodados "medias tintas", condenan a todos aquellos que aspiran a trascender su posición social. Asimismo, el autor asocia a estos subalternos con el concepto de bestialidad, especialmente en el caso de la mujer, al decir que la "mulata dio unos cuantos pliegues al hocico, como quien medita". Con estas palabras, Pardo y Aliaga no sólo asocia a la mujer con un animal, sino que alude a su consiguiente incapacidad de pensar o "meditar". De manera similar, en otra de sus obras, el cuadro de costumbres "El paseo de Amancaes" (1840), Pardo y Aliaga describe una mujer mulata “cabalgada en una veloz yegua, con el consabido sombrero acaramelado y el vasto copo de lanoso cabello sobre la espalda, y el rico monillo de raso verde botella, y el vestido de muselina, y la media de sarga, y el zapato de raso azul celeste, y el estribo descomunal, con descomunales cantoneras de plata" (696). En el pasaje, se critica el vano intento de la mujer de vestirse como las mujeres de las élites, que queda ridiculizado por sus combinaciones estridentes. Asimismo, la apariencia de la mulata se confunde con el animal, insinuando no sólo la semejanza entre ambos y el bestialismo asociado con los subalternos, sino que describe a una especie de mujer-centauro, colocando a la subalterna en el contexto de una monstruosidad mítica.

Unas décadas más tardes, Palma retoma la temática explorada por Pardo y Aliaga sobre los mulatos, pero, aun sin ser libre de prejuicios, los describe de manera mucho más 
amable. En "La emplazada" (segunda serie), el autor describe a unos esclavos mulatos cuyos semblantes sobresalen por ser extremadamente atractivos, y por tener un refinamiento que los diferencian de los esclavos más oscuros. En esta tradición, destaca la figura de Pantaleón, "un robusto y agraciado mulato", adoptado y muy estimado por una familia de condes (85). Este se enamora de Gertrudis, una esclava representada como una joven "traviesa como un duende, alegre ... y con un par de ojos negros, tan negros que parecían hechos de tinieblas" (87). Sin embargo, Pantaleón se convierte en víctima de las excesivas atenciones de la condesa a la que sirve, quien le mata en un arrebato de celos. Antes de morir, el mulato lanza una maldición sobre ella, por lo que esta cae enferma y también muere, castigada por "levantar hasta su altura a un miserable esclavo" (88). Aquí las palabras de Palma dan fe de la ambigüedad con la que se percibe este grupo étnico al que en parte pertenece. La oscilación entre aceptación y rechazo hacia los protagonistas hace que, por una parte, se alabe su comportamiento intachable y, por otra, que queden castigados tras obtener un protagonismo excesivo en la trama. Ambos mulatos son castrados simbólicamente, ya que a Pantaleón se le niega la descendencia, al morir tanto él como su enajenada amante, y la bella mulata Gertrudis obtiene la libertad, pero termina enclaustrándose en un convento, donde también se le negará la reproducción: “[1]a pobre mulata, cuya fatal belleza fue la causa de la tragedia, partió una hora después para Lima, y tomó el hábito de donada en el monasterio de las clarisas” (n.p.). De este modo, se impide la ulterior incursión de los mulatos y el mestizaje dentro de la sociedad limeña.

Uno de los protagonistas recurrentes en las tradiciones de Palma, es el ilustre mulato Bernardo José Monteagudo (1789-1825). Nacido en Argentina, vivió entre esta 
tierra y el Perú ejerciendo de político y militar, y convirtiéndose en ministro peruano. Monteagudo pasó a la historia por promover y participar activamente en los procesos de independencia hispanoamericanas. Sin embargo, en las tradiciones de Palma este político es retratado de manera ambigua, y en ningún momento se menciona abiertamente su etnia. En "Bolívar y el cronista Calancha" (cuarta serie), el autor señala la arrogancia del "altivo Monteagudo", que compara con la de Bolívar (n.p.). Sin embargo, también aflora la admiración de Palma hacia este personaje en cuanto a su papel en el movimiento de independencia hispanoamericana frente a los colonos españoles. En "Los caballeros de la capa" (segunda serie) afirma que

... en los tiempos antiguos nadie que aspirase a ser tenido por decente osaba presentarse en la vía pública sin la respectiva capa. Hiciese frío o calor, el español antiguo y la capa andaban en consorcio, tanto en el paseo y el banquete cuanto en la fiesta de iglesia. Por eso sospecho que el decreto que en 1822 dio el ministro Monteagudo prohibiendo a los españoles el uso de la capa, tuvo, para la Independencia del Perú, la misma importancia que una batalla ganada por los insurgentes. Abolida la capa, desaparecía España. (n.p.)

En "El conde de la Topada" (séptima serie) aflora de nuevo el rechazo por parte de Monteagudo hacia las costumbres y los privilegios peninsulares, especialmente en lo que se refiere a los títulos nobiliarios y la limpieza de sangre. En la tradición se describe un noble arruinado que apuesta y pierde su título de conde, por lo que su nuevo dueño solicita el paso de propiedad del título enfatizando, además, su limpieza de sangre por ser 
asturiano. Sin embargo, "la real cédula confirmatoria cayó en manos de Monteagudo, y... el ministro la aproximó a la bujía para encender con ella un cigarro" (n.p.). En la obra de Palma, las actitudes del autor hacia el mulato son ambiguas, puesto que aprecia el rechazo del ministro hacia las costumbres y el gobierno peninsular, pero no parece estimar su persona o sus actuaciones políticas. Otras tradiciones en las que se menciona al mulato Monteagudo son "El médico inglés" (octava serie), en la que Palma habla sobre la supuesta impopularidad de Monteagudo, y "Agua mansa" (sexta serie), protagonizada por el teniente Mantilla, un militar despedido por el gobierno en 1826 como consecuencia de la falta de fondos durante el proceso de independencia del Perú. El oficial se dirige a Monteagudo en busca de ayuda, pero este le dice con desprecio que "se meta a ladrón". Por consiguiente, Mantilla roba un banco y es capturado, pero, a pesar de alegar que tan sólo cumplía órdenes de su superior, el militar es fusilado por insubordinación. De este modo, Palma indica sus reservas en cuanto a las actuaciones del ministro mulato, aunque su rechazo se centra en cuestiones políticas más que por razones raciales.

Finalmente, junto al hombre "racialmente" marcado, la mujer subalterna, objeto de la exclusión racial y de género, es un tipo recurrente en los discursos peruanos decimonónicos. Tal como se ha discutido en la sección 4.3, en la obra de Palma abundan las descripciones de mujeres mulatas, enfatizando su naturaleza seductora, su papel en la "mejora de la raza", y los efectos (negativos) que esta puede tener sobre los niños y la sociedad en general. Entre otros autores del periodo que hablan sobre la mujer y la cuestión racial destaca González Prada, quien culpa a la mujer por el mestizaje, ya que en Lima "abundan los mulatos, pues, merced a una aberración étnica las blancas han tenido inclinación a mulatos y negros" (González Prada, Tonel 218). Según González Prada, la 
mujer criolla representa la frivolidad, los vicios, la ignorancia y la caduca moral, religiosidad y sociedad de la Colonia (Velázquez, Mirada 293). Su función se describe como meramente reproductiva, pero se critica su poder de seducción y su potencial para unirse con afrodescendientes (293-94).

5.4. "Mestizo educado, diablo encarnado"

A pesar del generalizado rechazo hacia la hibridación, los mestizos (hijos de blancos y nativos americanos) son tratados de forma ambigua en los discursos peruanos decimonónicos. Existe un fuerte complejo de inferioridad entre limeños criollos o racialmente mezclados frente a las comunidades blancas occidentales, alimentado por la situación social del país tras la Independencia. Entre otras cuestiones, destacan el declive de la economía peruana en la segunda mitad del siglo XIX y la derrota sufrida en la Guerra del Pacífico (1879-1883), situaciones que hacen que la diversidad étnica se asocie con la decadencia social, financiera y militar. Este sentimiento de inferioridad causa que las élites de mulatos y mestizos traten de desligarse de grupos de subalternos, como los nativos, chinos y afrodescendientes, a menudo responsabilizados de aspectos como el declive urbano, étnico y social.

En la obra de Ricardo Palma, no faltan referencias hacia la cuestión del mestizaje. La propia condición étnica del escritor pardo hace que no abunden las referencias hacia los mestizos y que tales descripciones sean ambiguas. Por una parte, son descritos de manera positiva, mientras que en otras ocasiones condena su rol en la mezcla racial. En la tradición "Un obispo de contrabando" (quinta serie), ambientada en el siglo XVI, Palma habla de los mestizos del pasado en los siguientes términos: 
Los mestizos, casi siempre fruto del connubio de una india con un español, fueron generalmente odiados por los naturales del país; y a su turno los mestizos, cuando alcanzaban algún mando o un cacho de influencia en la cosa pública, eran para con los pobres indios más soberbios y crueles que los españoles mismos, que habían necesitado que Roma declarase por breve del Papa Paulo III, expedido el 10 de junio de 1537, que los indios americanos no eran bestias de carga, sino seres racionales y capaces de sacramentos. De esta odiosidad de razas vino sin duda el decir: "Mestizo educado, diablo encarnado". (n.p.)

Por lo tanto, según Palma, los mestizos de la Colonia se encuentran en una situación liminal que los sitúa entre las élites blancas y el pueblo, formado mayormente por nativos. En el contexto decimonónico, el enfrentamiento entre "razas" se une al proceso de formación identitaria nacional, en un país en el que las élites de criollos, mulatos o mestizos pasan a ocupar puestos cada vez más elevados en el escalafón social.

El potencial para el bien y el mal de los mestizos aflora a menudo en la obra de Ricardo Palma. En su "Hilachas" (quinta serie), un conjunto de tradiciones breves, Palma incluye el relato "¡Arre, borrico! Quien nació para pobre no ha de ser rico", donde retrata a un nativo que, tras encontrar una mina de plata sin dueño, confió en un amigo mestizo para tomar posesión de la explotación. Sin embargo, el mestizo le engaña, aprovechándose de su analfabetismo y poniendo la mina a su nombre. A pesar de sus quejas a las autoridades, el indio no puede demostrar legalmente su hallazgo y la mina queda en manos del traicionero mestizo. Otra traición ocurre en "El castigo de un traidor" 
(séptima serie), en el que Palma se inspira en un suceso histórico, la fallida conspiración de Amancaes (1750), en la que los indígenas pretenden rebelarse contra los españoles debido a su represión (O'Phelan 7, 22). Scarlett O'Phelan describe uno de los detonantes que desencadenan la rebelión de este modo:

En 1750 el Rey Fernando VI promulgó una real cédula ordenando que ni los mestizos, ni los mulatos, se desempeñaran como escribanos o notarios y recomendó que no fueran nombrados para tales puestos aun en calidad de interinos. Además se estipulaba que tanto mestizos, como mulatos y cuarterones, fueran prohibidos de matricularse en las universidades reales y de ingresar como novicios a las órdenes religiosas... [En] Lima, la nobleza indígena había logrado franquearse un espacio bien consolidado como escribanos de indios. Esta nueva medida debió afectarlos y resentirlos profundamente. (13)

En la tradición, Palma afirma que el mestizo Jorge Gobea fue el culpable del fracaso de la conspiración de Amancaes, ya que este traicionó a los sublevados: “[e]1 26 de junio fue día de gran alarma en la ciudad; porque el gobierno se echó a hacer prisiones, no sólo de indios principales, sino de algunos negros influyentes en las cofradías africanas" (n.p.). Una vez más, un mestizo traiciona a nativos y afroperuanos de su comunidad, aunque en esta ocasión, sus actos no quedan impunes; los revolucionarios le capturan, le cortan la lengua para castigar su deslealtad, y finalmente, le arrojan a los perros hasta provocar su muerte. O'Phelan nos recuerda de que los enfrentamientos entre criollos y europeos, mestizos y mulatos, nativos y afrodescendientes, en cualquiera de sus 
combinaciones, son a menudo fomentados por los gobiernos coloniales (19). Como ejemplo, O'Phelan señala que a los indígenas se les permite poseer esclavos negros, lo que se consideraba una muestra de estatus social, por lo que la separación y antagonismo entre los dos colectivos es insalvable (19).

A pesar de retratar negativamente a algunos mestizos, y su índole traicionera, en otras tradiciones, Palma los describe de manera ambigua. En "Lucas el sacrílego" el autor retrata a un mestizo que roba las joyas que adornan la efigie de un santo en un monasterio, y es ahorcado por las autoridades de la Colonia a pesar de mostrarse arrepentido y compensar la pérdida (101-02). En estas breves descripciones, podemos intuir el descontento del autor en cuanto a la situación de mestizos y mulatos, y su rechazo hacia las opresoras autoridades coloniales y religiosas. Palma parece sugerir que, aunque el mestizo encarna los vicios de su linaje, es capaz de arrepentirse y modificar su conducta si es guiado diligentemente. Asimismo, en otras tradiciones, el talante del autor hace una descripción más positiva de los mestizos. En “El castigo de un traidor” (séptima serie), Palma describe una heroica sublevación contra los españoles en la década de 1740 . El autor describe como, a pesar de ser traicionados, un grupo de revolucionarios de distintas etnias se unen contra unos enemigos comunes, quienes "[s]e tomaron grandes precauciones para que los indios y mestizos, negros y mulatos, no se amotinaran" (86). A pesar de los esfuerzos de los españoles, no consiguieron evitar esta primera revolución, que fue reprimida poco más tarde. En esta tradición Palma pone énfasis sobre el carácter encomiable de mulatos, mestizos y otros subalternos, especialmente en su insubordinación ante las autoridades coloniales. En la tradición “Después de Dios, Quirós" (tercera serie) también se retrata a un mulato loable, quien, tras perder su ganado, 
decide donar sus últimos ahorros a un pobre. Su buen corazón hace que, gracias a la "providencia" y la donación de un generoso filántropo, el mestizo recupere con creces su pérdida. Otras fugaces menciones hacia los mestizos se hacen en la tradición "La monja de la llave" (segunda serie), en la que se mencionan a dos ricas herederas quienes, a pesar de tener una gran dote tienen el "defecto" de ser mulatas.

En conclusión, el origen racial de Palma, un pardo - mezcla de indio, negro y blanco-, colisiona con el ideal nacional de "mejorar la raza". Esta condición, compartida por muchos peruanos, ocasiona un movimiento pendular en los discursos de Palma y sus contemporáneos. Por un lado, el tradicionalista se distancia de la mezcla "racial", y desvincularse de su propia etnia, mientras que, por otra parte, lamenta las injusticias sufridas por mestizos y mulatos, especialmente en el periodo colonial. Al mismo tiempo, esta incertidumbre identitaria se refleja en otros aspectos de la vida social peruana. Mientras la pugna de criollos, mestizos y mulatos para mejorar su posición social los lleva a distanciarse de los españoles, también se desata el rencor tanto entre estos grupos como entre otros subalternos, como los nativos y afroperuanos, empeñados en recuperar los derechos que se les niegan durante y después de la Colonia. 
6. “Cholos", "piezas de ébano", y "culíes": las tipificaciones raciales en los discursos decimonónicos

El concepto de tipificación humana, ya en efecto en los discursos de la antigüedad clásica, pasa por la división de castas-clases durante la Colonia Latinoamericana y, finalmente, toma un matiz científico en el siglo XIX. A partir de este periodo, la discriminación cultural y social se mezcla con la noción pseudocientífica de que existen razas humanas separadas, y, en el Perú postcolonial, la llegada de estas teorías europeas se une a la necesidad de reafirmar el lugar en el mundo de la nueva nación y sus habitantes. Muchos nativos, afroperuanos y asiáticos, viven en una situación de desventaja frente a otras etnias, ya que, mientras a estos, por lo general, se les niega todo tipo de movilidad social, mestizos, mulatos o criollos, pueden llegar a ser miembros de la élite o trascender su posición social con más facilidad. Según Patricia Oliart “[t]ras la independencia, las élites necesitan reorganizar la sociedad para que los Estados fueran aceptados como naciones modernas por Europa sin eliminar la aristocracia, los mecanismos de dominación y el estilo de vida de la Colonia", por lo que "[s]e elabora un ambiguo aparato ideológico que compagina aspectos de las estructuras capitalistas y coloniales" (Oliart, "Poniendo" 263). Por consiguiente, el proyecto de reestructuración social de la Republica Peruana impulsa la adopción de una demarcación étnica especialmente rígida, debido al propósito de las élites de mantenerse en el poder separándose de las "razas" subalternas.

Entre los denominadores que indican que las desigualdades de la Colonia tienen cierta continuidad en la República Peruana, destaca el hecho de que la esclavitud y el tributo indígena siguen en vigor hasta 1854. En este año, se decreta la abolición oficial de 
estas prácticas, pero otros subalternos, como los llamados "culíes" -trabajadores de ascendencia asiática-, siguen sufriendo en condiciones de servidumbre o semi-esclavitud en las décadas siguientes. En una carta en la que habla sobre su amistad con Ricardo Palma, Rubén Darío observa que en "Lima hay familias de noble y pura sangre española", mientras que en "el pueblo de Lima" convive "la más extraña confusión de razas: chino y negro, blanco y chino, indio y blanco, y las variaciones consiguientes" (Palma, Tradiciones en salsa 122). De este modo, el poeta observa la separación étnica entre la nobleza y el pueblo: mientras el primero se compone de personas de "pura raza española", es decir, de blancos, el segundo se caracteriza por la "confusión" étnica debido a la mezcla entre "razas puras". De modo similar, Ladislao Graña (1817-1862), un español afincado en Jauja, en su tesis titulada Factores sociales de delincuencia en el Perú (1899), traza una separación entre clases, sugiriendo una afinidad entre tendencias criminales y ciertas razas (Aguirre, "Delito" 11). El autor habla de etnias "inferiores" peruanas, entre las que incluye la cruel "raza" española, la indígena, la negra y, finalmente, la china, que "ocupa la última esfera de la humanidad” (Graña 735, 727 en Aguirre, "Delito" 11). Una división distinta es la que hace Clemente Palma en su tesis $E l$ porvenir de las razas, argumentando que las etnias principales del Perú son la india, la española, la negra, la china, la mestiza y la criolla (2). Este último grupo (el del autor) se distingue por ser una mezcla de todas las anteriores y heredera de sus mejores rasgos físicos y morales (2). Según Clemente Palma, debido a su naturaleza "casi perfecta”, la raza criolla sólo necesita de la buena influencia del medio y de la "raza" alemana para alcanzar la perfección (2). 
Aunque en el siglo XIX conviven distintas definiciones de los que se consideran “distintos grupos de razas", las categorías normalmente separan a subsaharianos, blancos, nativos americanos y asiáticos. Entre numerosos autores decimonónicos latinoamericanos, "español” es sinónimo de "blanco"; sin embargo, a menudo se traza una diferenciación entre los dos imaginarios, tal como hace Clemente Palma, quien afirma que "la raza española", aun siendo "muy superior a la india, no ocupa, en las razas superiores, un sitio muy elevado" (1). Los discursos sobre los blancos se han discutido en el Capitulo 3, sobre los Otros internos y externos, puesto que la discriminación hacia los colectivos de origen europeo se centra generalmente en su nacionalidad, religión o bajo nivel socioeconómico, más que en su fenotipo. Surgen así, en la obra de Ricardo Palma, tipos como el "gringo" estadounidense "borrachín”, el "bachiche” italiano pobre, el colono español perezoso y despótico, o el judío avaricioso. A pesar de estas descripciones, el blanco (incluido el español) ocupa un puesto más alto en la jerarquía social decimonónica. Por el contrario, el primer rasgo identificativo de amerindios, afroperuanos y asiáticos del Perú es típicamente el color de su piel, lo que se convierte en instrumento de marginalización, explotación o paternalismo.

Actualmente, delinear la distribución étnica (o de fenotipos) del Perú decimonónico resultaría irracional. Tal como indica Paul Gootenberg en Población y etnicidad en el Perú republicano (siglo XIX), la información proporcionada por los censos anteriores a 1876 es ambigua o inexacta (5). Asimismo, existen otras cuestiones problemáticas a la hora de delimitar los grupos étnicos de una población. La primera aflora a la hora de definir "qué es" un grupo étnico o racial. Sin embargo, tal como se ha discutido en el Capítulo 2, la ciencia y la sociología no ha podido proporcionar elementos 
concluyentes para diferenciar grupos raciales discernibles entre humanos. El segundo problema emerge al considerar cuestiones identitarias, ya que todo individuo, independientemente de su fenotipo o afiliación cultural, puede sentir afinidad hacia un grupo étnico concreto u otro, e identificarse con el mismo. Otro problema surge con el llamado "blanqueamiento", que tiene lugar cuando una persona se identifica con una etnia blanca para evadir ciertas obligaciones o la estigmatización social, como es el caso de los impuestos coloniales aplicados a los indígenas (Peloso y Ragas 286). Consecuentemente, el resultado de toda encuesta diseñada para censar la población resulta inconcluyente debido a la imposibilidad de establecer grupos étnicos separados. Por otra parte, críticos como Benedict Anderson, Vincent Peloso y José Ragas, opinan que los censos son vitales en "la construcción del imaginario de la nación", por lo que es importante su mención en todo estudio sobre Otredad y "raza" (Peloso y Ragas 288; Anderson 163).

Paul Gootenberg señala que los censos que se llevan a cabo entre 1790 y 1876, en realidad, eran documentos que "registraban los tributos indígenas y de "castas"” (6). En su estudio indica que en el censo de 1791 del virrey Gil de Taboada, en el Perú se cuentan 1,076,997 habitantes, entre ellos, “609,000 indios, 244,000 mestizos, 136,000 blancos, 41,000 pardos y 40,000 esclavos negros” (7). Sin embargo, Gootenberg también indica que estas cifras son extremadamente ambiguas y que los grupos encuestados pudieron sospechar que el propósito del censo era el de imponer nuevos impuestos por parte de la Corte borbónica por lo que cabe especular que estos intentaron ocultar o alterar su etnia y posición social (7). Aunque después de 1791 se realizan otros censos, o censos parciales, como los de 1812, 1836, 1850 y 1862, estos son marcados por 
importantes irregularidades (5). En 1876, se realizó el primer censo moderno del Perú, que revela marcadas divisiones sociales entre etnias, clases y poblaciones urbanas y rurales (13). Estos índices son importantes, puesto que, tal como Peloso y Ragas especulan, en la década de 1860 se produce un aumento de la población indígena en Lima debido a la fuerte migración del campo a las ciudades (287). Según la nueva información recopilada por el censo de 1876, el país cuenta con 2,699,106 habitantes, de los cuales 1,554,678 son considerados indios, y “el 15 por ciento de la población vivía en pueblos (incluyendo la mayoría de los 498 "israelitas" peruanos confesos)" (Gootenberg 13). Los censos decimonónicos, han sido analizados, entre otros, por Bruno Lesevic y Francisco Pini, George Kubler y Paul Gootenberg. Utilizando los datos de estos estudios, Jesús Cosamalón señala que el censo de 1876 la población peruana se distribuye del siguiente modo: 


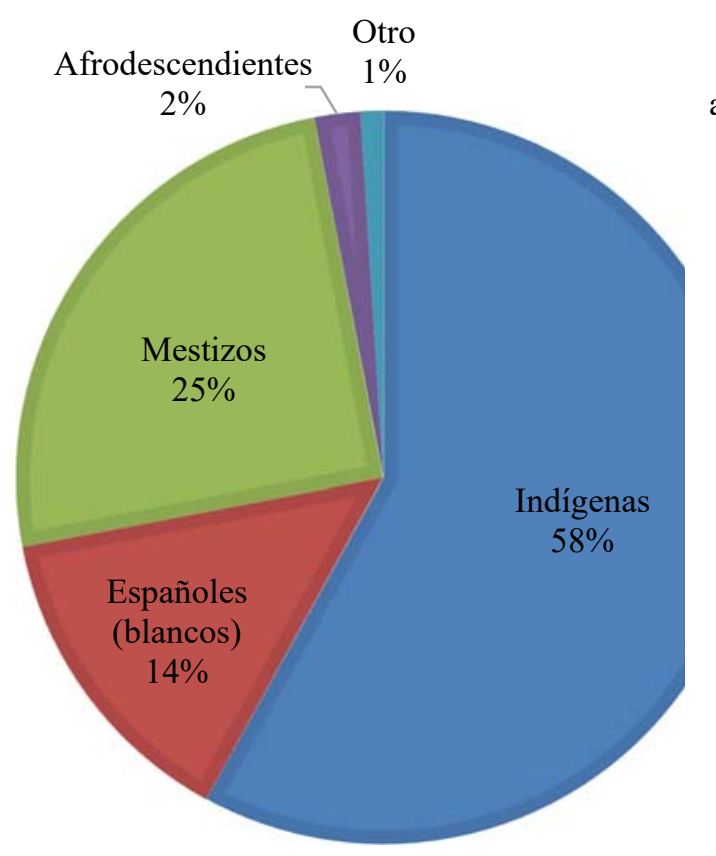

Distribución étnica en el Perú, 187ı

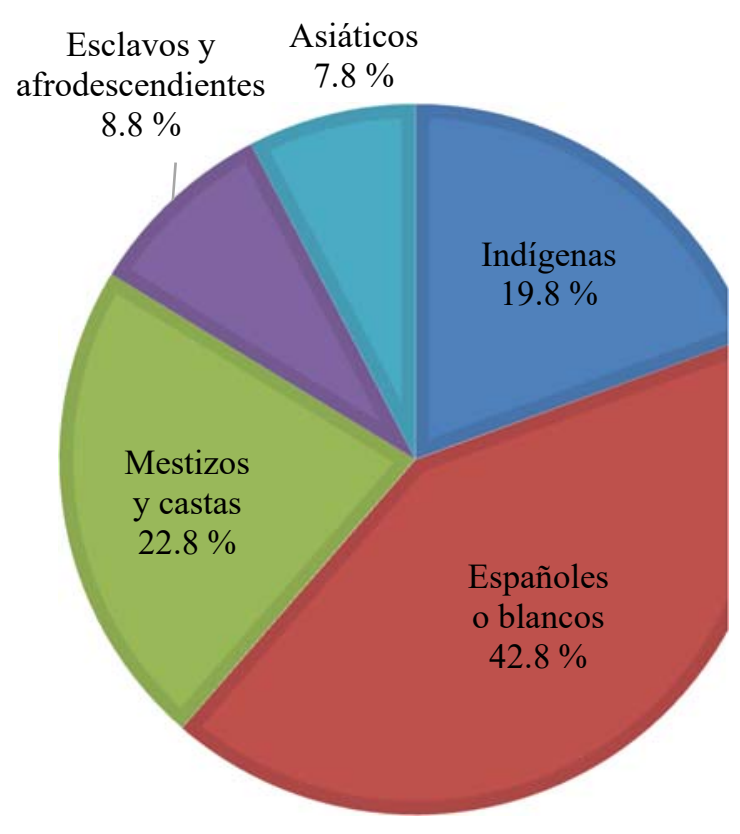

Distribución étnica en Lima, 18:

Tabla 3. Distribución étnica en el Perú y en Lima, 1876 (Cosamalón 235)

De los estudios sobre los censos peruanos efectuados por George Kubler, en The Indian Caste of Peru, 1795-1940, publicado en 1952, y, más tarde, por Paul Gootenberg, emergen importantes cuestiones sobre la situación de los nativos americanos. Kubler afirma que el número de nativos peruanos culmina tras la independencia, constatando que en este periodo llegan a un " 59.3 por ciento $(651,993)$ ", seguido por el " 57.6 por ciento de 1795 ", y un "54.8 por ciento en 1876 , cuando se hizo evidente la senda moderna hacia el mestizaje" (Gootenberg 14). El sector amerindio es el que más sufre durante la Colonia, e incluso tras la llegada de la Independencia, contando con un alto grado de analfabetismo y, en su mayoría, desterrado en las zonas rurales hasta la segunda mitad del 
siglo XIX, cuando empieza su éxodo hacia las periferias urbanos. Tales cuestiones emergen a menudo en la literatura decimonónica, en la que se denuncia la explotación de los nativos durante la Colonia mientras se discute su lugar en la República.

6.1. "Extranjeros en su propia tierra": los nativos en los discursos decimonónicos Al igual que en otros países de las Américas, el indoperuano es un Otro nacional que, aun siendo nativo en su tierra, es típicamente considerado marginal o incluso extranjero. Ejemplo de ello son los discursos de los primeros conquistadores españoles, quienes orientalizan y "extranjerizan" a los habitantes de las Américas, alegando que provienen de Asia, con el fin de legitimar la colonización del Nuevo Mundo (CamaydFreixas 1). Las legislaciones coloniales negaban a los nativos derechos básicos como la elección de su indumentaria o las uniones conyugales. Asimismo, al tener un estatus legal similar al de los menores de edad, se les prohíbe montar a caballo y firmar contratos, obligándoles a pagar un tributo a la Corona o a los encomenderos (Twinam, Purchasing 89).

A pesar de la situación precaria de los nativos, desde comienzos de la Colonia surgen discursos de defensa de este colectivo, como es el caso de la obra de Guamán Poma de Ayala (ca. 1535-ca.1616), el Inca Garcilaso de la Vega (1539-1616), y el fraile dominico Bartolomé de las Casas (1484-1566), un clérigo cuyos tratados, aun sin ser carentes de paternalismos, defienden la necesidad de un trato más digno hacia los indígenas. La oscilación entre rechazo y defensa de los subalternos en la Colonia sigue vigente en épocas posteriores mediante el uso de argumentos que, en ocasiones, se han mantenido invariables a lo largo de los siglos. En el Perú republicano, la labor de 
marginalización racial iniciada en la Colonia continúa e incluso prolifera debido al influjo de nuevas teorías de marginación, como es el caso del racismo científico europeo, que propone teorías sobre la "inferioridad innata" de los subalternos. Asimismo, a menudo, los discursos racistas se fortalecen, puesto que, tal como indica Edward Said, el surgimiento del nacionalismo anticolonial puede ocasionar golpes militares, guerras civiles, fanatismo religioso y persecución de los nativos (Orientalism xvii). Cabe indicar que, en los comienzos de la República, los subalternos indígenas y afroperuanos, pero también las clases sociales bajas, son desdeñados, en un intento de definir una "nación peruana" que excluye a tales grupos sociales.

En este contexto, cabe indicar la proliferación de apelativos despectivos utilizados para designar a los nativos peruanos, y que se utilizan en los discursos decimonónicos como la obra de Palma. Cecilia Méndez indica que, a finales del siglo XVIII y en el XIX, términos como "indio" o "serrano" ("habitante de la sierra") son utilizados a menudo para estigmatizar a los nativos ("Incas Sí" 53). Sin embargo, este uso no se hace en gran parte de la época colonial, ya que los nativos no son considerados individuos ligados a la tierra o a un lugar concreto, sino que pueden encontrarse tanto en la sierra y en las montañas, como en la costa (53). Entre otros insultos que perduran hasta el día de hoy destaca el uso de la palabra "cholo" que no sólo designa a indios, mestizos o mulatos, sino que indica su supuesta naturaleza vulgar o se mofa de aquellos nativos que "pretenden" adoptar las costumbres occidentales (Real Academia).

Tras la marginalización de los indígenas en tierras peruanas, no sólo destacan las influencias europeas coloniales y postcoloniales. Una serie de desastres económicos como la derrota del Perú en la Guerra del Pacífico incrementan aún más el uso de tales 
estereotipos. Jeffrey Klaiber señala que Chile, con un gran porcentaje de población blanca, se enfrenta a un Perú principalmente compuesto por nativos (27). El desenlace, no sólo confirma la superioridad económica y militar chilena, sino también fortalece el imaginario sobre la supremacía blanca en Chile frente a la inferioridad de nativos o mestizos peruano (27). Cabe destacar el hecho de que "la fuerza y la debilidad" del cuerpo es comparada con la fortaleza o el declive de la sociedad (Mannarelli 24). Elisa Sampson argumenta que tras la Guerra del Pacífico la ideología de Palma se endurece, culpando a los indígenas de las fuerzas armadas por provocar la derrota debido a su falta de patriotismo (Ricardo 6).

Otro fenómeno fundamental es la migración desde las zonas rurales hacia las urbanas, que culmina en el siglo XX pero empieza a intensificarse en la segunda mitad del siglo XIX. En este periodo, inicia un proceso que, tal como señala Eddy Romero, modificará el semblante del país para siempre, culminando en el fenómeno de cholificación de la segunda mitad del siglo XX, descrito por Aníbal Quijano (n.p.). Romero señala que, a medida en que se avanza hacia el siglo XX, los "antiguos indígenas serán tratados como cholos, pero en algún momento el tono despectivo se convertirá en tono descriptivo", se forman distritos marginales formados por migrantes y el "racismo" se convierte paulatinamente en una "discriminación por idioma, cultura y nivel socioeducativo" (n.p.).

Aunque en el Perú decimonónico los indoperuanos son típicamente víctimas de la marginación y del paternalismo de los discursos hegemónicos, escritores como Palma los retratan de manera ambigua. Tal como nos recuerda James Higgins "Palma se disocia de los abusos de la Conquista, retrata a los incas en términos respetuosos, critica la 
explotación de los indios, denuncia la esclavitud y la discriminación racial. Sin embargo, ... conceptúa a la clase media limeña como el núcleo de la sociedad peruana y otros sectores ocupan una posición marginal en su modelo de la nación” (n.p.). En una carta a Nicolás de Piérola, en la que reflexiona acerca de la Guerra del Pacífico, Palma afirma que "la mayoría del Perú la forma una raza abyecta y degradada", y que "el indio", a pesar de haber sido dignificado y ennoblecido, "no tiene el sentimiento de patria; es enemigo nato del blanco... [y es] orgánicamente cobarde" (Sarco 182; Palma, Cartas 20).

Con todo, el Perú decimonónico también es testigo del auge de discursos (proto)indianistas o (proto)indigenistas, dos corrientes artísticas, políticas y antropológicas que surgen en el siglo XIX y la primera mitad del XX. A pesar de haber sido consideradas dos movimientos separados (siendo el indianismo precursor del indigenismo), hoy en día se hace hincapié en la coyuntura entre estas corrientes. Tradicionalmente, en las obras "indianistas" se ha destacado la idealización romántica o sentimental de los indígenas, dejando en un plano secundario la denuncia de su situación social (Vargas Yábar 33-34). En ocasiones, el indio se describe como un héroe mítico nacional, mientras que en otras es representado como un mártir, víctima de la explotación colonial. Según Concha Meléndez, Aves sin nido de Clorinda Matto de Turner es "la primera novela indianista de reivindicación social", puesto que "la idealización romántica del referente indígena eclipsa el carácter denunciatorio" (Vargas Yábar 33-34). El "indigenismo", por otro lado, ha sido definido como un movimiento que da precedencia a la denuncia social de la situación de los amerindios (33-34). Según Aida Cometta, Aves debería considerarse la primera novela de este grupo, puesto que es precursora de un movimiento militante para la mejora social del indígena, y sus descripciones sobre los 
nativos son realistas, sin mistificación (Vargas Yábar 33-34). El artículo "Nuestros indios" (1904) de Manuel González Prada también ha sido incluido en estas corrientes, aunque su participación es ambigua puesto que el autor sugiere que los indígenas deben ser agentes de su propia mejora social, desvinculando a blancos y criollos de este colectivo. Finalmente, otros críticos como Antonio Cornejo Polar y Ana Peluffo afirman que el indianismo y el indigenismo no son movimientos excluyentes ya que "el sentimentalismo y la política" no son "irreconciliables e incompatibles" y ambos han sido utilizados simultáneamente en los discursos de los siglos XIX y XX (Cornejo, Literatura y sociedad 33, 36-38; Peluffo 13).

Los discursos indigenistas o indianistas también están presentes, en distinta medida, en la obra de Mariano Melgar (1790-1815) y sus fabulas de corte independista que reivindican el lugar de los nativos peruanos en la Colonia; y en la trilogía de Clorinda Matto de Turner que incluye las novelas Aves sin nido (1889), Índole (1891) y Herencia (1895). ${ }^{42}$ Debido a su estrecha relación con Ricardo Palma, cabe destacar la obra de Matto, caracterizada por su acercamiento a las tendencias reformadoras y modernizadoras de su país. A pesar de compartir ciertos puntos de vista con otros escritores del periodo como Palma, la autora discrepa con las tendencias más conservadoras y tradicionalistas

\footnotetext{
${ }^{42}$ En épocas posteriores, los discursos indigenistas o indianistas afloran en la poesía de José Santos Chocano (1875-1934), inspirada en la vida de los nativos y las cuestiones de mestizaje; en la obra del escritor franco-peruano Ventura García Calderón (1886-1959), con una visión ambigua hacia los indígenas; los cuentos de Abraham Valdelomar (1888-1919); la obra de Enrique López Albújar (1872-1966), conocido por su novela Matalaché (1928), protagonizada por un esclavo mulato; y la del historiador Luis Eduardo Valcárcel Vizcarra (1891-1987), quien revaloriza las civilizaciones inca y andina. Asimismo, ya en el siglo XX, destacan los peruanos Gamaliel Churata (1897-1969), con su obra El pez de oro (1957); Ciro Alegría (1909-1967), con El mundo es ancho y ajeno (1941); José María Arguedas (1911-1969), con Los ríos profundos (1958); Eleodoro Vargas Vicuña (1924-1997), con sus cuentos y poesías; y Manuel Scorza (1928-1983), con sus novelas y obra poética.
} 
de su época. En las Tradiciones cuzqueñas (1884) de Matto encontramos una amplia variedad de Otros que interactúan en el Perú decimonónico. La colección, que cuenta con un prólogo de Palma, está indudablemente inspirada en sus Tradiciones peruanas, aunque Matto se centra mayormente en el mundo prehispánico y la vida provinciana (Cornejo, Prólogo x). ${ }^{43}$ Las facetas más encomiables de las Tradiciones de Matto son su crítica a los fanatismos religiosos (que comparte con Palma) y su férrea defensa de los derechos de los indígenas, que emerge en sus escritos posteriores, como Aves sin nido. $\mathrm{Su}$ propósito es el de concienciar sus contemporáneos acerca de la explotación de los indios, denunciando el estado de semi-esclavitud al que están sometidos durante la Colonia:

Por desgracia está probado que los conquistadores hallaron en el Perú dos géneros de minas a cual más abundantes para explotarlas de ricos metales encerrados en el seno de la tierra, y las minas hablantes que contaban en cada mita. No eran otra cosa los pobres indios que producían pingües fortunas para el patrón, cosechando para sí la ingratitud y el oprobio, pues como afirma un historiador de nuestros días, los Corregidores y Sub-intendentes obligaban a comprar cosas de desecho como si fueran de primera necesidad: les vendían mulas cansadas, granos averiados; vino picado, tres o cuatro veces más caro que si hubiese sido excelente

\footnotetext{
${ }^{43}$ La obra de los dos autores concuerda en muchos elementos, diferenciándose en aspectos como su nivel de madurez, ya que, mientras Palma escribe en un periodo de plenitud, Matto se halla al comienzo de su trayectoria literaria (Campbell 494-95). Por su parte, Palma integra en sus tradiciones un amplio abanico de fuentes históricas, mientras que Matto se basa casi en su totalidad en Los anales de Cuzco de Diego Esquivel y Navía (494-95).
} 
sin otro derecho que el de ser objetos que vendía la autoridad. (Matto, Tradiciones

A pesar de sus encomiables intenciones, mientras los personajes españoles y criollos tienen un papel individualizado, en las Tradiciones cuzqueñas los nativos son sujetos anónimos y colectivos (Velázquez, "Narrativa" 82-83). Asimismo, Cornejo Polar indica que, en buena parte de la novela indigenista, al igual que en Aves, el escritor nunca es un nativo, por lo que a menudo los orígenes (andinas) de los indígenas se sitúan "fuera de la historia" (Prólogo xv). De este modo, el mundo de los nativos se presenta "más como parte de la naturaleza que de la historia" (xv). Cornejo Polar sostiene que el argumento decimonónico sobre la formación de la nacionalidad emerge en el momento en el que las dos niñas indígenas que protagonizan Aves son adoptadas y asimiladas dentro de una familia de blancos (xviii). Al perder su apellido y recibir una educación en la alta sociedad limeña, terminan adoptando una nueva identidad y quedan aglutinadas dentro de una nueva y "homogénea" clase social (xviii). De este modo, se sugiere que la raza indígena no tiene futuro por lo que debe ser "rescatada" por manos piadosas: "[l]a salvación del indio depende de su conversión en otro, en criollo" (xviii).

En la obra palmina, el indígena asume un rol típicamente estático y de mero instrumento para impulsar la trama, y sus rasgos dominantes son la ignorancia, la superstición, y la idolatría. En otras ocasiones, el nativo es relegado al papel de víctima de los colonos, retratándose como un ser infantil, indefenso y explotado, incapaz de rebelarse o subsistir de manera independiente. La cuestión de la educación de los indígenas, tan importante en la ideología positivista de la época, es central en los 
discursos decimonónicos. Mientras Matto insiste en este aspecto pedagógico, Palma muestra una actitud ambigua y cambiante. El tradicionalista minimiza su rol sugiriendo que "[e]ducar al indio" equivale a "inspirarle patriotismo", y que "será obra no de las instituciones sino de los tiempos" que este alcance una mejor formación (Sarco 182; Palma, Cartas 20). Asimismo, en Cachivaches, su colección de obras misceláneas, el autor indica que los nativos se apartan voluntariamente de la educación, quedándose estancados en el pasado, ya que, desde sus orígenes, "el indio, con la conciencia de su debilidad, es sombrío como el último rayo de luz", por lo que "gran parte del pueblo indiano prefirió sepultarse en las cuevas, con sus ídolos, sus tesoros y sus recuerdos” (Cachivaches, "El hermano de Atahualpa" 4). Por otro lado, sus opiniones en cuanto a la educación no son constantes. En Anales de la Inquisición afirma que el colectivo indígena se caracteriza por el "atraso y supersticiones dominantes en una raza que está lejos de ser refractaria á la civilización y á la que, multiplicando las escuelas, es fácil apartar de torpes errores y de estravagantes costumbres tradicionales" (248).

La perspectiva de Palma sobre la superstición e obscurantismo del nativo aflora en tradiciones como "Carta canta" (tercera serie), donde el autor afirma que la "sencilla ignorancia de los indios atribuía a la escritura un prestigio diabólico y maravilloso" (145) y en "La sandalia de Santo Tomás" (cuarta serie), donde se subraya que tal ignorancia hace que "los indios idólatras" den a la escritura una "significación diabólica" (214). En ellas, podemos detectar los estereotipos de la época sobre la etnia nativa americana, considerada decadente en comparación con las comunidades blancas o criollas. Otro punto clave en este imaginario, es el temor hacia la hibridación con los indios, considerada un elemento de desprestigio entre los peruanos, puesto que tras la 
independencia se produce un intento de la élite republicana de Lima de establecerse como una comunidad "racialmente" superior (Oliart 285).

Asimismo, a parte de un fugaz protagonismo en algunas tradiciones, las mujeres “indias” quedan poco más que mencionadas en la obra de Palma. Esto ocurre, por ejemplo, cuando el autor alude al hecho de que sus protagonistas son hijos o hijas de india y blanco. El rechazo hacia la mezcla racial con las nativas se percibe en la tradición "Un obispo de contrabando" (quinta serie), en la que el autor afirma que los "mestizos, casi siempre fruto del connubio de una india con un español, fueron generalmente odiados" en el Perú colonial (n.p.). Por otra parte, destaca la representación cambiante de los nativos, quienes, en ocasiones, son compadecidos o incluso respetados, como observamos en la tradición "San Antonio de Montesclaros" (cuarta serie), en la que Palma describe al indígena como víctima de la brutalidad del español. En la tradición, el administrador de una mina, el español Ireneo Villena y Gorrochátogui, es descrito como un "hombre muy de la cáscara amarga y que por un pelillo mataba a palos a un indio, como quien mata a un perro sarnoso. Según él, para los cholos no había cielo ni infierno, sino purgatorio eterno en esta vida y en la otra" (n.p.).

Por otra parte, las mujeres nativas son descritas con relativa benevolencia, en comparación con sus homólogos masculinos, quienes a menudo son tachados de vagos, ignorantes y deshonestos (Oliart, "Poniendo" 284). Sin embargo, las mujeres indígenas parecen elementos asexuales y silenciosos, cuya invisibilidad facilita su marginalización. Según Patricia Oliart, a finales del siglo XIX, las nativas eran representadas principalmente en sus roles de madres, vendedoras y labradoras, aunque a menudo "se pone en duda su higiene y cuidado" (283-84). Estas eran consideradas unas resistentes y 
toscas trabajadoras, sin muchas demandas, condenadas a ser maltratadas por sus indolentes esposos y a trabajar para mantenerlos, por lo que su fidelidad es a menudo puesta en entredicho (284). Sin embargo, aunque no sean objeto de crítica o queden "reducidas a su capacidad reproductora", se desalientan las uniones con las nativas, puesto que tales enlaces perjudican el "blanqueamiento" o "mejora" de la raza peruana (284). Estas mujeres representan una "raza" considerada decadente, y son incluso comparadas por escritores como Clemente Palma con el indeseable "ganado chusco", producto desvirtuado del cruce entre distintas castas de animales (284).

Aunque en la obra de Ricardo Palma en contadas ocasiones se menosprecia las mujeres indígenas, estas están relegada a un rol secundario y no adquieren protagonismo casi en la totalidad de su obra. En la tradición "El puente de los pecadores" (cuarta serie), una india cobra un protagonismo fugaz como narradora de una historia sobre un conocido puente. Según el autor, en 1810, una india sin nombre estaba atravesando el puente cuando este se derrumbó, pero la mujer se encomendó a la Virgen del Carmen, quedando milagrosamente transportada hasta el otro lado de rio (324-25). Otras nativas anónimas, retratan en su rol de vendedoras, son mencionadas en "Nadie se muere hasta que Dios quiere" (segunda serie) y en "La victoria de las camaroneras" (séptima serie). En esta segunda tradición, un grupo de indias camaroneras se enfrentan a unas pescaderas por su lugar de venta, hasta que la paz es finalmente reinstaurada y se establece un decreto para que las camaroneras tengan su lugar delimitado y que "las demás indias negras y mulatas no las inquieten ni perturben" (n.p.). En otras circunstancias, como en la tradición "Las brujas de Ica” (sexta serie), las indígenas son descritas como mujeres crédulas y supersticiosas, ya que "venían desde largas distancias y le pagaban un peso por consulta" 
a un adivino famoso (310-11). Finalmente, la estigmatización de las nativas es más visible en la tradición "Un obispo de Ayacucho" (quinta serie), donde son descritas como “cholas", asociándolas con la vulgaridad y la obscenidad: "Cinco o seis cholas, de las de mantitas corta y faldellín alto, formaban rueda agarradas de las manos. Cuatro o seis voces aguardentosas cantaban coplas obscenas, y al compás de un mal charango y de una pésima guitarra zapateaban las mujeres una cachua abominable" (n.p.).

Según Marcel Velázquez-Castro, el fenómeno de invisibilización y estigmatización de los subalternos en los discursos decimonónicos está presente tanto en la obra de Palma como en la de sus contemporáneos como Manuel González Prada (a pesar de considerarse un escritor indianista o indigenista) (Las máscaras 275). Tales discursos, en lo que se alterna aceptación y rechazo hacia el Otro, incluyen a indios, mujeres y afroperuanos, "negándoles el protagonismo como actores de la modernidad" (275).

6.2. "Piezas de ébano", morenos, y cimarrones: afrodescendientes en el Perú ${ }^{44}$

Desde la antigüedad, la negritud ha sido objeto de desdén y violencia por parte de las sociedades no subsaharianas. En el Antiguo Testamento, la leyenda de Cam es interpretada por comunidades judías, cristianas y musulmanas como una "maldición

\footnotetext{
${ }^{44}$ Véanse los artículos de Oswaldo Holguín Callo, "Ricardo Palma y la cultura negra" (2000), y Richard Leonardo “'Los negros no saben amar'. Nación, representación y exclusión en 'La emplazada' de Ricardo Palma" (2015), y los libros de Carlos Aguirre, ed., Lo africano en la cultura criolla (pp. 97-120); María Rostworowski, et al., eds., Lo africano en la cultura criolla (2000),
} 
lanzada por Dios contra los hijos de Noé", quienes son condenados a la negritud debido a sus pecados (Delacampagne 216). ${ }^{45}$ Según Carlos López-Beltrán,

El primer "otro" con el que el europeo establece la polaridad de la diferencia es el negro. De hecho, no se insiste en la blancura del europeo sino hasta que se establece la dualidad en cuestión. Esta polaridad radical explicaría, quizá, algunas de las diferencias que encontramos en los regímenes de blanqueamiento de la Nueva España, y el estigma tan brutal sobre la ascendencia negra. (323)

La esclavitud subsahariana fue una institución fundamental durante la Colonia y las primeras décadas de la República Peruana. Con el propósito de abolir la esclavitud de manera paulatina, en 1821, José de San Martín promulgó la "libertad de vientres", decretando la libertad para los hijos de esclavos nacidos tras esa fecha, pero la esclavitud no es eliminada hasta 1854 por el gobierno de Ramón Castilla (Aguirre, Agentes 84). Tal como indica Eddy Romero, los esclavos negros son cosificados y reducidos al rol de "herramientas de trabajo" u "objetos eróticos", por lo que son apodados despectivamente "piezas de ébano" (n.p.). Asimismo, Romero señala que su bestialización aparta a los afroperuanos del mundo intelectual, inscribiéndolos "en la esfera de los instintos", y, especialmente la inclinación sexual (n.p.). Según Marcel Velázquez, Palma utiliza unas estrategias muy definidas para representar a estos subalternos que se puede extrapolar a otras etnias (Máscaras 184). En primer lugar, la escasez de representaciones de

${ }^{45}$ En Génesis 4:15, 9:25-27. Véanse Ward (82-83) y Popkin (79-102). 
(esclavos) negros es un paso hacia su marginalización, puesto que tan sólo sobresalen cuando se trata de sujetos excepcionales, bien por sus admirables servicios políticos o religiosos, bien por tener rasgos atractivos, como el hecho de ser extremadamente bellos y mulatos; es decir, no completamente negros (184). En segundo lugar, los esclavos suelen tener roles secundarios y no son descritos como individuos independientes, sino como prolongaciones de la cultura dominante y de la ideología, la religión y la honra de sus amos (184). Finalmente, si estos Otros muestran actitudes y habilidades independientes, la trama narrativa los castiga súbitamente y, a menudo, de manera violenta (184). ${ }^{46}$ Los afroperuanos descritos por Palma y sus contemporáneos son frecuentemente víctimas inocentes de las circunstancias en las que se encuentran o sufren un destino injusto debido a su condición social.

La esclavitud se discute y es criticada en la columna "La Tijerita" del periódico El Correo Peruano, que Palma escribe junto a otros jóvenes periodistas (autodenominados Los noticiosos) (Pérez Garay 61). En esta columna diaria los escritores critican la permisividad de Castilla hacia el tráfico negrero, aplaudiendo a José Hilario López, presidente de la República de Colombia, por abolir la esclavitud (61). Sin embargo, con el paso del tiempo, los discursos de Palma se vuelven más conservadores, distanciándose paulatinamente de la polémica (61). La situación de los afroperuanos en el Perú y la esclavitud como institución también son mencionados con frecuencia en las Tradiciones.

\footnotetext{
${ }^{46}$ Véase Cecilia Valdés (1839), la novela del escritor cubano Cirilo Villaverde, en la que su protagonista mulata, Cecilia, pretende vivir por encima de su clase social y étnica. La joven se enamora de un criollo blanco que resulta ser su hermano, y concibe un hijo fuera del matrimonio, pero es castigada por la trama al ser abandonada por su amante.
} 
En "El rey del monte" (tercera serie), Palma se lamenta del pasado colonial y de la esclavitud que acompañó a los europeos dese su llegada las Américas:

Con el cristianismo, que es fraternidad, nos vino desde la civilizada Europa y como una negación de la doctrina religiosa, la trata de esclavos. Los crueles expedientes de que se valían los traficantes en carne humana para completar en las costas de África el cargamento de sus buques, y la manera bárbara como después eran tratados los infelices negros, no son asuntos para artículos del carácter ligero de mis tradiciones. (903)

Esta actitud de reproche es común entre los escritores de la República, partidarios de la Independencia, ya que forma parte de la retórica de rechazo a las autoridades coloniales. Sin embargo, lejos de ajustarse a la realidad, el esclavo negro sigue sufriendo vejaciones y castigos corporales incluso tras la emancipación (Aguirre, "Silencios" 2627). En la tradición "La gran querella de los barberos" (séptima serie), Palma habla sobre el decreto de un arzobispo de 1626, que imponía el descanso a los limeños todos los domingos, "el día del Señor", dándole, además, "un día de alivio a la multitud de esclavos" que no aspiran a "otro descanso que en su muerte" (n.p.). El autor se pone de parte del clérigo, explicando sus razones y su punto de vista sobre la esclavitud:

... el arzobispo de Campo (muchos cronistas le llaman de Ocampo) pretendió con este edicto aliviar la desventurada condición de los negros esclavos y de los indios mitayas o sujetos a las antiguas encomiendas, a quienes amos y encomenderos 
avarientos obligaban a trabajar con brutal exceso. ... A mi juicio, el edicto de su ilustrísima tanto era político como evangélico.... Sepan ustedes que sólo del contrato ajustado en julio de 1696 entre el Consejo de Indias y la compañía real de Guinea para la introducción en América de treinta mil negros, correspondieron al Perú doce mil esclavos, que se vendieron en el Callao desde 300 hasta 400 pesos ensayados cada uno. La sexta parte quedó en el servicio doméstico, y fue la menos desdichada; pero el resto pasó a las rudas faenas agrícolas, donde el látigo, esgrimido por feroz caporal, andaba a nalga qué quieres. Adivinar se deja que el edicto archiepiscopal fue acogido con entusiasta aplauso por siervos y servidores, y visto de mal ojo por la gente rica y acomodada... (n.p.)

Mas detalles sobre la esclavitud en la Colonia, afloran en la tradición "Una carta de indias" (segunda serie), donde Palma habla sobre un suceso de 1540, cuando el licenciado español D. Cristóbal Vaca de Castro es enviado "a poner orden" en el Perú y la Nueva Granada (n.p.). Sin embargo, su avaricia hace que caiga en desgracia al dejarse corromper en su nuevo cargo, pero "Carlos V, poco antes de su abdicación, apiadose del licenciado y lo rehabilitó y aun concedió mercedes, siendo la principal permitirle introducir en América, sin pago de derechos, quinientas piezas de ébano, o sea esclavos africanos" (n.p.). Otra fugaz referencia a la esclavitud se hace en "Callao y Chalaco" (séptima serie) donde Palma afirma que para "la construcción del actual Callao, por ruina del antiguo a consecuencia del terremoto e inundación de 1746, se emplearon, en calidad de peones y albañiles, negros esclavos de la tribu o cofradías de los chalas" (n.p.). En “¡Mata! ¡Mata! ¡Mata!” (quinta serie) Palma escribe que, en 1753, el marqués Don 
Alonso González del Valle, "poseía una hacienda de viña, tenida por la más valiosa de Ica. Ochocientas piezas de ébano y azabache, vulgo esclavos, estaban de seis a seis en la pampa y en el lagar, dando al amo anualmente una ganancia líquida de cuarenta mil duretes" (n.p.). En "Un general de antaño" (octava serie) un esclavo negro, alentado por su ama, tira una piedra al general Antonio José de Sucre (1795-1830), y pierde su vida acto seguido, al ser fusilado por otro general, debido a una indiscreción de su propia ama (n.p.). Asimismo, en "Un tenorio americano" (quinta serie), Palma menciona a una conocida personalidad histórica mulata, el ministro Bernardo José Monteagudo (17891825), prosélito del dictador rioplatense Carlos María de Alvear (1789-1852). El dictador es descrito por Palma, quien destaca su labor en la revolución argentina y su postura en cuanto a la liberación de los esclavos y su colaboración con el mulato Monteagudo:

D. Carlos María de Alvear es una de las más prominentes personalidades de la revolución argentina... Presidente de la primera asamblea constituyente, fue él quien propuso en 1813 la primera ley que sobre libertad de esclavos [que] se ha promulgado en América. En la guerra civil que surgió a poco, Alvear, apoyado en la prensa por Monteagudo, asumió la dictadura, y la ejerció hasta abril de $1815 \ldots$ (n.p.)

Sin embargo, las actitudes de Palma hacia los esclavos y los afroperuanos en general, son extremadamente ambiguas. En la tradición "La venganza de un cura" (sexta serie), Palma recoge la historia del doctor Mansilla, Oidor de la Real Audiencia durante el Virreinato, "quien entre sus esclavos tenía un negrito chamberí, al cual mimaba más de 
lo preciso" (n.p.). Este "engreído muchacho" cometía delitos de los que "salía bien librado, porque el señor oidor interponía su influencia y respetos" (n.p.). Otras tradiciones de Palma donde aparecen afrodescendientes o referencias a la esclavitud son "Los malditos" (segunda serie), en la que un negro presencia de manera involuntaria un ritual "pagano", y "Un alcalde que sabía dónde le apretaba el zapato" (séptima serie), en la que un "engreído negro" enciende un conflicto entre un alcalde y un oidor. En "Mogollón" (segunda serie), el azar hace que se descubra que un negro liberto, del que se sospecha por tener más dinero del que le corresponde a su clase social, ha estado robando, por lo que es castigado con unos azotes.

Oswaldo Holguín, en "Ricardo Palma y la cultura negra", indica que la personalidad afroperuana en Palma se caracteriza por tener dos rasgos principales que se nutren se los estereotipos tradicionales sobre estos subalternos (112-13). En primer lugar, destaca su "lisura", es decir, su descaro e informalidad a la hora de hablar, que permite al autor imbuir sus Tradiciones de un lenguaje popular vibrante y facilita su intención satírica e iconoclasta (113-14). La "lisura" afroperuana aflora en "Con días y ollas venceremos" (segunda serie), donde se describe al mayordomo de Pizarro como "un negrito retinto, con toda la lisura criolla de los budingas y mataperros de Lima, gran decidor de desvergüenzas" (n.p.). Una actitud similar es la descrita en "Un litigio original" (primera serie), en la que los carruajes de dos nobles convergen en un estrecho callejón, e, incitados por sus amos, los esclavos cocheros se enzarzan en una pugna de insultos con tal de no ceder el paso:

Ambos cocheros detuvieron las bridas, y el del conde dijo al otro: 
-¡A la izquierda, negro bruto!

-¡Déjame la derecha, negro chicharrón! -contestó el auriga del marqués.

Y los dos macuitos siguieron insultándose de lo lindo. ${ }^{47}$

Los amos asomaron la cabeza por la portañuela y, al reconocerse, dijeron a sus esclavos:

-No cedas, negro, porque te mato a latigazos.

Y siguió el escándalo, y cuantos nobles salían de la iglesia rodearon las portañuelas de los coches. (1964: 489)

Tal como observa Marcel Velázquez, los esclavos son representados, no como individuos independientes, sino como una extensión de la honra de sus amos, por lo que “el conflicto asciende de manera jerárquica desde los carruajes, pasando por los esclavos y hasta llegar a los nobles" (Máscaras 171).

En segundo lugar, según Holguín destaca la sensualidad que se le atribuye a los negros, especialmente las mujeres, un erotismo asociado con las danzas africanas y la belleza de las afroperuanas ("Ricardo Palma y la cultura" 114-15). Este es el caso de la mulata, Veremunda, en "La victoria de las camaroneras" (séptima serie), cuyo nombre es digno de mención debido a su extraordinaria belleza. Veremunda es una joven con "boca entre turrón almendrado y confitado de cerezas", retratada con un lenguaje abiertamente sexual (n.p.). Aunque considerando estas premisas Holguín sugiere que Palma fue un "un partidario de la multietnicidad peruana", Velázquez nos recuerda que la sociedad peruana

${ }^{47}$ El término "macuito" es un peruanismo que se utiliza como "un apelativo familiar otorgado a los negros" (Velázquez, Máscaras 171). 
es fuertemente jerárquica y que en las Tradiciones la mujer negra "casi siempre pertenece a comunidades subordinadas y el hombre a las dominantes" (Velázquez, Máscaras 168; Holguín, "Ricardo Palma y la cultura" 118).

En las Tradiciones no faltan referencias a la supuesta fealdad, idolatría o incluso satanismo de los afrodescendientes. Este es el caso de la tradición “;Beba, padre; que le da la vida!" (cuarta serie) donde se describe a un hombre "negro retinto y feo como un demonio", o en "Los endiablados" (primera serie), donde Palma menciona a "un corro de monos bravos y budingas" (n.p.). Estos individuos son identificados con la barbarie y animalismo puesto que el término bundinga es utilizado para describir a los afrodescendientes, y puede asociarse con el apelativo mandinga, empleado para designar al diablo y a las personas o lenguas de "Senegal, Costa de Marfil, Guinea, Guinea-Bisáu y Malí" (Real Academia). Asimismo, "Más malo que Calleja" (segunda serie), protagonizada por un afroperuano descrito como "un pobre negro, caballero en burro", es otro ejemplo de tradición en la que el afrodescendiente es asociado con el bestialismo. Este relato, ambientado en 1815, narra la historia del capitán Don Martín Calleja quien, tras tropezar con el esclavo negro y su burro, intenta evitar al animal pisando un charco y manchándose los pantalones. Encolerizado, el capitán mata tanto al burro como al esclavo, pero los limeños que presencian la escena le apedrean y le llevan ante la justicia. A pesar de la indignación popular ante tal crueldad, "el fiscal opinó que la vida de un esclavo no valía un pepinillo ni merecía tanta alharaca, y que a lo más que podía obligarse a don Martín era a pagar al amo del negro cuatrocientos pesos por el muerto y veinte por el burro" (n.p.). De este modo, la vida del esclavo es comparada con la del animal, y el asesino es simplemente obligado a pagar los daños de perdida de las dos 
"propiedades" dañadas. En otras ocasiones, los afroperuanos son asociados con aspectos de la mala vida como el abuso del alcohol y la violencia. En "Un Maquiavelo criollo" (séptima serie), Palma describe a un afroperuano ebrio y agresivo, cuya embriaguez lleva a molestar a un limeño criollo. Este no se altera, pero motiva al afrodescendiente para que siga importunando a otros viandantes: "redobló su atrevimiento y desacato con los transeúntes, hasta que se encontró con uno de la cáscara amarga, el cual le aplicó tanta leña que lo hizo pedir pita... Acudieron los celadores, llevándose al negro al hospital con la cabeza rota, un brazo desencuadernado y dos costillas hundidas" (n.p.). De este modo, el Maquiavelo criollo se venga de la afrenta sin riesgos, sugiriendo, no solo la tendencia al vicio del afroperuano, sino también su superioridad intelectual.

Las descripciones negativas de estos individuos pueden responder a la ubicua presencia del concepto de oposición entre la "civilización" europea y la "barbarie", asociada con la naturaleza indómita de las Américas y con las etnias no blancas en general. En este contexto, no es de extrañar que la negritud llegue a considerarse una enfermedad. El filósofo afrocaribeño Frantz Fanon (1925-61) es muy consciente de la presencia de este tipo de discriminación étnica y nos recuerda que los afrodescendientes son estigmatizados hasta el punto de ser asociados con el bestialismo (8). Esta ideología se ve reforzada en el siglo XIX como consecuencia de las teorías científicas, especialmente de la biología, que pretendían demostrar que los subsaharianos se encuentran a medio camino entre el simio y el hombre.

A pesar de este rechazo generalizado, en Palma no faltan contadas alusiones a su aceptación en la sociedad peruana, como en "Un negro en el sillón presidencial” (1910), donde el autor cuenta una curiosa anécdota en la que la ficción se mezcla con los hechos 
históricos que tienen lugar en1835, cuando en Lima “el negro León Escobar, capitán de una facción de treinta bandidos", aprovechó un vacío de poder para ocupar el Palacio de Gobierno (n.p.). Tras recibir "cinco mil pesos para atender a su gente”, el noble bandido se fue sin causar inconvenientes, por lo que se decía que "el retinto negro, en el sillón presidencial, se portó con igual o mayor cultura que los de piel blanca" (n.p.). Asimismo, "La Fundación de Santa Liberata" (segunda serie) es protagonizada por un niño esclavo, Tomás Moya, que, testigo de un robo, identifica el ladrón y recibe una recompensa. Como observa Marcel Velázquez, es una de las pocas tradiciones en la que se utiliza el nombre completo de un afroperuano, y que este tiene un final feliz y (Mascaras 172). El talante positivo también se aprecia en "Croniquillas de mi abuela", donde el autor habla sobre padre Panchito, "un negro retinto" con "fama de virtud y santidad" (n.p.). Según el autor, este clérigo era muy estimado por el devoto virrey de Lemos, quien justificaba su predilección afirmando que el "talento y la virtud no son blancos, negros o amarillos, y Cristo en el Calvario murió por los blancos, por los negros, por los amarillos, por la humanidad entera. Todos venimos de Adán y Eva, y las razas no son más que variedades de la unidad" (n.p.). Con estas palabras atribuidas al virrey se percibe una actitud relativamente tolerante. Sin embargo, este proceder no deja de responder a intereses personales del autor en su lucha por distanciarse de los afrodescendientes, quienes son, por un lado, denigrados $\mathrm{y}$, por otro, compadecidos con actitud paternalista. El escritor utiliza términos como "piezas de ébano", "macuito", "gallinazo de muladar", "negro bruto", negro retinto", "negro pájaro pinto", "pobre negro", "arcángel de chocolate" y "negro chicharrón”, con el posible intento de evitar asociaciones con estos Otros subrayando los rasgos que los diferencian (Velázquez, Máscaras 185). 
A diferencia de los hombres afroperuanos, y al igual que las mujeres indígenas, las mujeres afrodescendientes no son representadas con excesiva dureza, aunque no faltan descripciones en las que la aceptación se mezcla con el rechazo en los discursos decimonónicos. Sus representaciones son variadas, aunque suelen tener un papel secundario y, cuando cobran protagonismo, sus roles suelen ser el de criada, nodriza, o esclava. Un estereotipo frecuente es el de la negra o mulata como objeto de deseo sexual. Tal como señala Carlos López-Beltrán, la “erotización del otro es la otra cara de la estigmatización", ya que, en la época colonial, los "españoles erotizan a la india, a la mestiza, a la negra, a la mulata" mientras que "desprecia[n] al varón, por vago, descastado, trashumante, ladrón" (326). En este periodo, la mujer es sometida "al dominio sexual y a la reproducción" hasta el punto de que esta condición es interiorizada tanto por los europeos como para los Otros raciales (326). ${ }^{48} \mathrm{El}$ componente sexual de los afroperuanos y mulatos en la Colonia está muy presente en la obra de Clemente Palma:

Aparte de un hecho puramente fisiológico, como era la sensualidad del negro y el ardor del español y del mestizo, había una circunstancia que favoreció los cruzamientos rápidos, a pequeñez de la población y la enormidad de territorio que abarca el virreinato. Otra circunstancia: la forma en que vino el negro al Perú: como esclavo, y en esa condición la negra tenía que entregarse ciegamente a la lujuria del amo y a la naciente de sus hijos. Por todo esto el español y el mestizo

\footnotetext{
${ }^{48}$ Según Patricia Oliart, a otras mujeres subalternas se les niega la sexualidad o atractivo, como es el caso de las indias, especialmente cuando estas son comparadas con el estereotipo idealizado de la mujer criolla (Oliart, "Poniendo" 283). Otro elemento que cabe señalar, es que, a diferencia de la india, rara vez la afroperuana es representada como pareja del hombre negro (283).
} 
no tuvieron repugnancia en mezclar su sangre con la raza negra y dar origen así al mulato, zambo, chino-cholo, cuarterón, etc. ... el mulato era más despierto que el mestizo, más activo, más astuto, más violento y ardoroso. Estas cualidades eran más saltantes en la mujer mulata, ... [a]lta, flexible, atrevida, infatigable para el placer, tenía una admirable expresión de gracia y frescura que seducía los sentidos y trastornaba el espíritu. Venus de canela, tenía en sus ojos negros, brillantes y provocadores las promesas más incitantes. ... convencida del poder que ejercía sobre los nervios del español y del mestizo, con el donaire de su cuerpo admirablemente modelado y de la hermosura picaresca de su rostro. Sacó este tipo las fogosidades africanas, el tinte moreno, como un recuerdo de la raza... (18)

En esta descripción, Clemente Palma hace hincapié en la sensualidad del colectivo afroperuano, especialmente en el caso de la mujer, obligada a entregarse al hombre blanco debido a su condición de esclava durante la Colonia y parte de la República. Sin embargo, la culpa de esta situación es súbitamente achacada a la afroperuana y, especialmente, a la mulata, quien "seducía los sentidos y trastornaba el espíritu", consciente "del poder que ejercía sobre los nervios del español” (18).

En la obra de Ricardo Palma, la presencia de mujer afroperuana es más discreta que en la tesis de su hijo. La falta de protagonismo parece responder a la carencia de representación de la que habla Marcel Velázquez, con el objetivo de invisibilizar a este colectivo (Máscaras 184). En "El Rey del Monte” (tercera serie) Palma hace una descripción pormenorizada de la situación de los esclavos durante la Colonia, hablando de las crueldades cometidas por los españoles, pero este grupo es retratado como un 
colectivo anónimo y sin voz. En la tradición habla de las costumbres de los esclavos, como es el caso de las procesiones en las que "[c]ada tribu tenía su reina, que era siempre una negra libre y rica", que en "la procesión solemne salía ésta con traje de raso blanco, cubierto de finísimas blondas valencianas, banda bordada de piedras preciosas, cinturón y cetro de oro, arracadas y gargantilla de perlas" (n.p.). Aunque en esta ocasión Palma no hace una referencia directa a la sexualidad de la mujer afroperuana, esta es descrita como un silencioso objeto de decoración, exhibido y embellecido con abalorios. Asimismo, la mujer es retratada como una noble "reina", que parece encarnar una ya inexistente y mítica nobleza africana. Esta perspectiva se refuerza a medida en que avanza el relato, en el que Palma describie una de sus "reinas", a la que nombra y describe con detalle:

La reina de los terranovas en 1799 era una negra de más de cincuenta inviernos, conocida con el nombre de mama Salomé, la que habiendo comprado su libertad puso una mazamorrería... Años llevaba ya nuestra macuita en pacífica posesión de un trono tan real como el de la ruina Pintiquiniestra. Pero ¡mire usted lo que es la envidia! Como nadie alcanzaba a hacer competencia a la acreditada mazamorrería de mama Salomé, otra del gremio levantó la especie de que la terranova era bruja, y que para hacer apetitoso su manjar meneaba la olla, jqué asco!, con una canilla de muerto, y canilla de judío, por añadidura. ¿Bruja dijiste? ¡A la Inquisición con ella! Y la pobre negra, convicta y confesa (con auxilio de la polea) de malas artes, fue sacada a la pública con pregonero delante y zurrador detrás, medio desnuda y montada en un burro flaco. ... Mama Salomé, reina de mojiganga o de mentirijillas, no se parecía a los soberanos de verdad, ... no 
intentó siquiera una revolucioncilla de mala muerte, se echó a dar y cavar en la ingratitud y felonía de los suyos; y a tal grado se le melancolizó el ánimo, que sin más ni menos se la llevó Pateta. (“El Rey del Monte” n.p.). ${ }^{49}$

En un primer momento, Palma describe a una mujer afroperuana silenciosa y noble, asociándola con una imagen idealizada, una virgen en procesión o una sensual mujer cubierta de adornos. Sin embargo, Palma pasa inmediatamente a desmitificar tal imagen, describiendo a una de estas reinas "de mentirijillas" como una mazmorrera cuya nobleza sólo tiene valor dentro de la comunidad afroperuana, que además termina traicionándola, acusándola de brujería.

Al igual que en "El Rey del Monte", en Palma aparecen varias menciones sobre la mujer negra en relación con la brujería o la superstición. En estas tradiciones el autor hace hincapié en la ignorancia de los subalternos-especialmente las mujeres-, quienes creen en lo sobrenatural y se resisten al progreso. Ocasionalmente, tanto en la época de Palma como en la Colonia, nativos y afroperuanos son asociados con la brujería, o descritos en el papel de curanderos, un hecho que colisiona fuertemente con el anticlericalismo de Palma. En "Las brujas de Ica" (sexta serie) el escritor menciona a una "negra repugnantísima, encubridora de robos y rufiana, muy diestra en preparar filtros amorosos, alfiletear muñecos y (¡Dios nos libre!) atar la agujeta” (n.p.). Asimismo, en "La apología del pichón palomino" (séptima serie), Palma afirma que, en 1804, en una gaceta limeña, "apareció la noticia de que... una negra terranova, llamada Asunción,

${ }^{49}$ El término coloquial "Pateta" es utilizado como sinónimo de diablo (Real Academia). 
había parido un pichón de paloma" (n.p.). De este modo, el autor se burla una vez más de las supersticiones asociadas con los afroperuanos, condenando la difusión de tales creencias y burlándose de los crédulos lectores del periódico.

Finalmente, en las tradiciones aflora una breve mención de la afroperuana en su papel de cuidadora o nodriza en "La niña del antojo" (tercera serie). En esta tradición, una limeña describe a los miembros de su familia, señalando a una pariente embarazada y a una "negra chicharrona, [que] es la mama que la crió" (n.p.). Aunque en Palma esta figura es casi totalmente ausente, en otros discursos decimonónicos la figura de la niñera, encargada de criar y amamantar a los hijos de limeñas adineradas, está asociada con la idea de que estas “nutrían” la imaginación de los niños con cuentos y, al llegar la adolescencia, los iniciaban sexualmente (Oliart, "Poniendo" 281-82). Por esta razón, escritores posteriores como el peruano Luis Abelardo Gamarra o el boliviano Gustavo Adolfo Otero, afirman que las niñeras afroperuanas son "las responsables del carácter débil y las actitudes inmaduras de los limeños" (282). ${ }^{50}$

6.3. Migrantes asiáticos en los discursos decimonónicos: los “culíes” en el Perú A mediados del siglo XIX, la escasez de mano de obra en el Perú -entre cuyas causas destaca la abolición de la esclavitud-, incita a las corporaciones peruanas a importar trabajadores desde Asia, trasladando entre 1849 y 1874 cerca de cien mil chinos hacia zonas rurales para desempeñar trabajos en los sectores del guano, el ferrocarril, y las haciendas costeñas (Watson, "Presencia" 182; Casalino 109, 114). En menor medida,

\footnotetext{
${ }^{50}$ Véase Luis Abelardo Gamarra, Lima: unos cuantos barrios y unos cuantos tipos. S.p.i., 1907, p. 19.
} 
estos trabajadores se quedan en las urbes, desempeñando tareas domésticas y estableciendo las primeras colonias de chinos (Casalino 114). Este influjo de inmigrantes, imprescindible para la industria de la época, tiene sin embargo el efecto de intensificar los discursos contra los trabajadores asiáticos, despectivamente apodados "culíes".

Watt Stewart indica que, según cifras aproximadas de la época, de los trabajadores chinos trasladados al Perú, unos 13.000 llegaron en la década de 1850; otros 38.648 entre 1860 y 1870 ; y unos 35.599 se unieron a los anteriores entre 1871 y 1974 , llegando a un total de 87.247 (73-74). En torno a 1883, en Lima empieza a formarse el "Barrio Chino" (en la zona de la calle Capón y el jardín Otaiza), que cuenta con el 24\% de los chinos de todo el Perú, por lo que la mayoría de estos inmigrantes se encuentran en zonas rurales (Casalino 122; Rodríguez Pastor 397; Sulén 56). Es importante destacar que los trabajadores eran forzados a aceptar convenios laborales extremadamente abusivos, siendo a menudo obligados a trabajar durante ocho años en estado de semi-esclavitud, recibiendo poca comida y un sueldo considerablemente bajo que podía "alcanzar los 400 pesos al inicio de la década de 1870" (Watson, "Presencia" 182; Rodríguez Pastor 39; Stewart 100).

Los chinos son además blanco de las acusaciones en los años entre 1890 y 1920 , cuando se extienden los discursos modernizadores higienistas y educativos (Casalino 115). Durante este periodo, se propagan epidemias -como la viruela, la peste bubónica y la fiebre amarilla- que se ceban con las clases con menos recursos, como los chinos, por lo que estos, a su vez, son culpados de su origen o propagación (115-16). Es importante subrayar que en el siglo XIX "[s]e distinguían dos tipos de herencia: la herencia ancestral o atavismo, que era la fuerza que conservaba las características de la raza; y la herencia 
patológica o de las enfermedades, dentro de la que se encontraba la sífilis, la tuberculosis, el alcoholismo, los tumores y malformaciones, las neurosis y perturbaciones del sistema nervioso y de la nutrición” (Mannarelli, Limpias 251; Pastor, Control 14). Según Carlota Casalino, los chinos fueron unas de las mayores víctimas de las contradicciones de los discursos xenófobos de la época (121). En este sentido, recibían fuertes críticas debido a su hacinamiento, sin considerar el hecho de que las propias industrias que los contratan los someten a condiciones infrahumanas, reuniendo un gran número de trabajadores en espacios reducidos, carentes de higiene o servicios (121). De este modo, chinos, afroperuanos y otros subalternos son a menudo acusados de resistirse a la modernidad, formando lo que se ha definido como "contracultura" (Casalino 119; Muñoz 18). La tesis de Clemente Palma, es un ejemplo de estos discursos racistas en los que se describe a la "raza" china enumerando sus supuestos rasgos identificativos:

La raza china, [es una] raza inferior y gastadísima, importada para la agricultura, cuando la República abolió la trata de negros, [es una] raza viciosa en su vida mental, completamente abotagada la vida nerviosa por acción del opio, [una] raza sin juventud, sin entusiasmos, de un intelectualismo pueril a causa de su misma decrepitud; y en la que el carácter de raza por el régimen despótico se ha hecho servil y cobarde... (7) 
De este modo, el autor resume los estereotipos de la época asociados con los chinos, su supuesta naturaleza débil y enfermiza, su "indolencia" hacia el prójimo, y su rechazo hacia la integración. ${ }^{51}$

A pesar de la fuerte inmigración asiática en el Perú, la presencia de este sector es relativamente limitada en los discursos literarios decimonónicos (Watson, "Presencia" 182). Ejemplo de ello es la obra de Ricardo Palma, en la que los chinos parecen desvanecer casi por completo. Tal carencia puede reflejar la invisibilidad social que sufre este colectivo en la época de Palma, ya que, considerados un molesto y temporal problema de Lima, los asiáticos son recluidos en guetos, apartados de la sociedad peruana. Aunque en obra palmina los chinos carezcan de protagonismo, el término "chino" o "china" es citado en numerosas ocasiones. Sin embargo, es importante destacar que, tanto en Palma como en otros discursos decimonónicos, el uso de este vocablo puede causar confusión para un lector contemporáneo. El término se utiliza a menudo en la América colonial y postcolonial para designar a un individuo "nacido de padres de distintas razas, especialmente de indio y zamba, o de zambo e india" (Real Academia). Según Clemente Palma la "raza" china es la de los "mulatos cuarterones" (hijos de español/a y mestizo/a), que "no llegó a producir mestizaje" ya que las demás "razas" sienten "repugnancia" hacia ella (2). Según el autor, estos supuestos defectos, junto a su nominal "debilidad genésica", el consumo de opio, y las condiciones infrahumanas en las que vive en Lima hace que el "mestizo de chino" salga "tan degenerado que no llega a la edad viril" (2).

\footnotetext{
${ }^{51}$ Otros ensayos racistas son los de Javier Prado y Ugarteche (1871-1921), historiador y filósofo que aboga
} por la "mejora de la raza peruana" mediante el cruzamiento con "razas superiores". 
Un tono mucho más positivo hacia las "chinas" como "mestizas" es el que usa su padre, Ricardo Palma, en sus Tradiciones. Este es el caso de la bella mulata, Gertrudis, en la tradición "La emplazada" (segunda serie), a la que Palma dedica unas rimas: "Pálido sería el retrato que emprendiera yo hacer de la mulata... Canela y azúcar fue/la bendita Magdalena... / quien no ha querido a una china / no ha querido cosa buena" (n.p.). En la cita, el término "china" se usa claramente como sinónimo de "mulata". De modo similar, en las tradiciones "Juana la Marimacho" (quinta serie) y “ißBuena laya de fraile!!” (segunda serie), se habla de la capeadora Juana (o Juanita) Breña, descrita como una atractiva y "gallarda mulata" que, en repetidas ocasiones, es calificada como "china" por el autor, uniendo este apelativo a la nominal naturaleza fogosa y sensual de la protagonista: ¡Ah, china diabla!”, “china de mis pecados” (n.p.). En otra ocasión, en la tradición "Un obispo de Ayacucho" (quinta serie), el término es utilizado para describir describir "[c]inco o seis cholas", absortas en un provocador baile donde un lujurioso clérigo pretende acercase a una de ella diciendo "[d]ame tus brazos, chinita" (n.p.). El hecho de que las "chinas" descritas son todas mujeres con rasgos atractivos, seductores o entrañables, sugiere que el termino es usado, además, como apelativo cariñoso hacia mujeres de etnia no blanca en general.

El santo de Panchita (1859), un sainete (obra teatral de carácter cómico) que Palma escribe con Manuel Ascencio Segura, es quizás el único ejemplo dentro de la obra del autor en el que se menciona a inmigrantes asiáticos, procedentes de China. En este caso, se trata claramente de chinos y no de individuos nacidos de padres de mestizos o mulatos. Su escasa representación, revela el rol marginal que tenía esta comunidad en la sociedad limeña. Sin embargo, la breve mención del sainete es especialmente llamativa, 
ya que los chinos son asociados con un amplio espectro de estereotipos. En el pasaje, dos de los protagonistas, Don Bruno y Doña Feliciana, discuten unos asuntos familiares mientras la anfitriona hace unas observaciones sobre la "nueva moda" de tomar té:

Felic. - Pues señor; hay algunos que prefieren el té al café, pero yo no le encuentro fundamento á tan nécia pretension. El tal té es un lavatripas y nada mas.

... Pero como esta de moda no hay mas, don Bruno, chiton. Y además, amigo mio, sépalo usted, por si no ha llegado á su noticia, que esa yerba la traen hoy envenenada.

Bru. — ¡Canastos! Pero ¿quién la envenenó?

Felic. — ¿No sabe usted quién? Los chinos, los macucos de Canton, esa gente escomulgada que nos traen en monton, y que allá, por la Pelota, un templo tienen ó dos donde adoran al demonio con cuchos y iqué sé yo! Pues como le iba diciendo, ¿no sabe por qué razon tanta muerte repentina hay en Lima? Pues, señor, es por el té envenenado; no le quede duda, no.

Pero está en moda beberlo, y en la moda ¿quién no entró?

Porque aquí somos tan monos, que si se usa en Nueva York ponerse, en vez do sombrero, una sarten ó un perol, de fijo nos lo chantamos mas huecos que un quitasol. (344-45) 
Al igual que otros subalternos, en esta breve mención se describe una comunidad sin rostro, con una idiosincrasia extremadamente estereotipada. Puesto que la obra se estrena en 1859, los autores la redactan en los primeros años de migración de chinos trabajadores en el Perú. El hecho de que son trasladados debido a los intereses de la industria del periodo es corroborado por Doña Feliciana, quien exclama que a los chinos los "traen en monton". En sus palabras, aflora el descontento social por los recién llegados, unos Otros extranjeros, "raciales" y religiosos, obligados a trabajar por un sueldo muy bajo, y considerados unos rivales laborales por los demás limeños.

Uno de los recursos descriptivos de exclusión más visibles es el componente religioso. En primer lugar, la religión de los migrantes es menospreciada y rebajada al nivel de "no religión", nominalmente tachada de pagana al ser posiblemente politeísta y “excomulgada" por la Iglesia católica. En segundo lugar, los chinos son asociados con la idolatría y el culto a figuras satánicas, ya que "adoran al demonio". Finalmente, el rechazo a esta comunidad se manifiesta mediante el descontento que se muestra al comprobar que los chinos construyen templos en Lima para practicar su religión, lo que puede interpretarse como una afrenta hacia a hermética sociedad cristiana limeña. Junto a la cuestión religiosa, aflora el estereotipo del "malcontento" o de "contracultura", del que participa la comunidad asiática, puesto que su propósito es el de "envenenar" a la población limeña que compra su té, siendo esta la razón, según Doña Feliciana, de que haya "tanta muerte repentina hay en Lima". A su preocupación se añade además una ideología común en la sociedad decimonónica que critica la “imitación” de la conducta extranjera, afirmando que los limeños son "tan monos" que si algo está "de moda" en "Nueva York" es inmediatamente adoptado o imitado. Finalmente, este breve fragmento 
critica la importación y uso de productos extranjeros, como es el caso de los productos chinos (como el té), pero también ocurre con los productos de otros países. En la segunda mitad del siglo XIX, los chinos empiezan a dedicarse a oficios que anteriormente atendían los nativos, como la preparación de comida y el comercio de opio, al que pronto se le suma el negocio del juego de azar, que atrae tanto a chinos como a limeños (Watson, "Presencia" 183). En la obra de Palma, otras fugaces menciones sobre la importación de productos chinos en el Perú afloran en tradiciones en las que el autor habla de "cohetecitos de la China", es decir, fuegos artificiales chinos ("Tras la tragedia el sainete”, tercera serie n.p.); "cinta de la China" ("Las cuatro PPPP de Lima”, séptima serie n.p.); y “campanillas chinescas” (“ijurra! ¡No hay que apurar la burra!”, cuarta serie, n.p.).

Además de la escasa descripción de chinos y productos asiáticos en la obra de Palma, existen otros discursos decimonónicos en los que emergen descripciones sobre esta comunidad. Reducidos a un estado de semi-esclavitud, los chinos son descritos como objetos -al igual que los esclavos africanos. Esta noción surge en la novela de Mercedes Cabello de Carbonera, El Conspirador (1892), en la que se describe el juego de naipes llamado "a chino apunte" en el que cada ficha representa "un chino" (Watson, "Presencia" 191). Los contrincantes se juegan, de este modo, a sus sirvientes asiáticos en carne y hueso (191). Entre otros trabajos que tratan el tema asiático, también destaca el ensayo titulado “¿Cuántos colores?”, de Manuel Atanasio Fuentes, incluido dentro de su obra Lima, apuntes descriptivos, estadísticos y de costumbres (1867). Asimismo, en su poema "Negro y amarillo", publicado en Iras Santas (1895), Juan de Arona describe a unos misteriosos y nobles asiáticos y afroperuanos, pero enfatiza su condición de 
exóticos extranjeros dentro del Perú. Asimismo, en su monografía histórico-crítica, $L a$ inmigración en el Perú (1891), Arona incluye un poema en el que afirma que el chino peruano se dedica a todo tipo de oficio y que incluso "de la plebe es sirviente", mientras que "la gente del país... ¡Está pensando en ser gente!” (89-90). Tal como indica Maida Watson, el pasaje sugiere que los chinos están dispuestos a desempeñar todo tipo de oficio, por vil que sea, e incluso a ser sirvientes de la plebe ("Presencia" 185). Con estas palabras, Arona critica las clases bajas, que repudian el trabajo y tan sólo pretenden "ser gente", es decir, aspiran a llegar a ser parte de la burguesía, y obtener un estatus social que no les corresponde (185). ${ }^{52}$ Otras obras, en las que emerge la cuestión asiática son, la novela anónima Nurerdín-Kan (1872), sobre el príncipe Hindú, Ofelia, Nurerdín-Kan, que abandona su patria tras la muerte de su amada y se embarca en un buque que transporta chinos culíes al Perú (Watson, "Presencia" 188). Nurerdín-Kan se pone de parte de los maltratados culíes y es comprado por un latifundista; sin embargo, mientras el indio es romantizado, los chinos son reducidos a un ridiculizado estereotipo (189-90).

\footnotetext{
52 Otros autores cuyos trabajos se muestran actitudes favorables hacia los chinos en el Perú fueron Dora Mayer (1868-1959) y Abelardo Gamarra Rondó (1850-1924).
} 


\section{Conclusiones}

La obra de Palma muestra un problema social muy extendido en Latinoamérica, donde la exclusión social de los grupos marginales está muy presente. Aunque no se puede afirmar que exista una continuidad absoluta entre la ideología colonial y postcolonial, los escritores del siglo XIX “inventan" o "reinventan" el colonialismo textualmente. Escritores como Palma, dirigen su mirada hacia el pasado y crean un universo ficticio que se mezcla con los acontecimientos históricos del periodo. En estos discursos, las costumbres y los personajes estereotipados de antaño se fusionan con los del presente decimonónico, y son utilizados para comparar el pasado con un presente incierto.

En el siglo XIX, los Otros de género siguen teniendo un rol secundario dentro de la nación peruana, las comunidades indígenas, afrodescendientes y asiáticas son marginadas y explotadas, y los rasgos de mestizos y mulatos son homogeneizados conceptualmente dentro de la sociedad criolla. Con la renegociación identitaria que se inaugura con la República, se favorece un "blanqueamiento" social, donde bien se ignoran las herencias indígenas y africanas, bien se trata de diluirlas. Este es el contexto en el que escriben Palma y sus contemporáneos, retratando una sociedad en la que la diversidad es silenciada, y los sujetos marginales son excluidos del ideal nacional decimonónico. Asimismo, otras características como la pobreza, la falta de educación formal, las creencias religiosas no cristianas, y las lenguas y escritura no hispanas quedan excluidas del "ideal” nacional.

Las ideas eurocéntricas que se propagan en la segunda mitad del siglo XIX, como la eugenesia, el darwinismo social, y el racismo biológico pseudocientífico, hacen que la 
explotación y el rechazo hacia las minorías queden nominalmente respaldados por los descubrimientos científicos. Asimismo, el encuentro entre distintas culturas y etnias en las Américas hace que a menudo unas queden asociadas con otras bajo un mismo concepto de discriminación y rechazo, como es el caso de las mujeres y los Otros "raciales". El desprecio hacia las mezclas étnicas hace que el control del cuerpo de la mujer sea fundamental, mientras los que se encuentran en los estratos sociales más bajos, compuestos principalmente por Otros raciales, rechazan su propia identidad, favoreciendo la mezcla con "razas superiores". Esta creencia se inculca de manera tan profunda desde los tiempos de la Colonia que algunos de sus efectos siguen vigentes en épocas posteriores.

Finalmente, la construcción de un modelo nacional ideal blanco, hace que las élites criollas sientan la necesidad de legitimar su posición social tras la independencia, procurando asimilar los ideales morales y étnicos de los colonos blancos. Para alcanzar este ideal es necesario controlar, no sólo a las mujeres, sino también a todos los grupos de subalternos, incluidos los Otros religiosos y las clases sociales trabajadoras. Estos sentimientos se perciben en la obra de Palma, quien intenta renegociar los términos de la identidad peruana construyendo un modelo nacional ideal que incluya su etnia y clase social. En este proceso se advierte una alternancia entre aceptación y rechazo hacia otros grupos, incluyendo los afrodescendientes, los indígenas e incluso los (descendientes) europeos, quienes anteriormente ocupaban de manera casi exclusiva los cargos más destacados en el gobierno nacional. Este sentimiento puede ser parte de la negociación de la posición social de un país donde, tras la independencia, el poder está en manos de 
criollos de posible ascendencia africana o indígena y, por lo tanto, es necesario difuminar las líneas divisorias entre etnias. 
Fuentes

Primarias

Anon. La Bella Limeña, periódico semanal para las familias. Imprenta Universo de Carlos Prince año 1, núm. 6, 12 Mayo 1872, pp. 41-48.

Anon. La Bella Limeña, periódico semanal para las familias. Imprenta Universo de Carlos Prince año 1, núm. 3, 21 Abr. 1872, pp. 19-24.

Bon, Gustave Le. The Pocket Cephalometer, or Compass of Coordinates, Allowing One to Very Rapidly Obtain the Diverse Diameters, Angles and Profiles of the Head, and To Reproduce in 3-D Any Solid Figure. 1929. Consultado 25 Apr. 2018.

Cabello de Carbonera, Mercedes. Blanca Sol. (Novela Social). 2a. ed. Imprenta y librería del Universo de Carlos Prince, 1889.

Covarrubias, Sebastián de. Tesoro de la lengua castellana o española. 1611, 1674. Ed. Martín Riquer. Alta Fulla, 1987.

Elguera, Federico. El barón de Keef en Lima: segunda época, Charlas con Soria. Librería e Imprenta Gil, 1919.

Fuentes, Manuel Atanasio, y Felipe Bailly eds. Biblioteca peruana de historia, ciencias y literatura. Colección de escritos del anterior y presente siglo de los más acreditados autores peruanos. Vol. 9. Librería central, 1864.

Fuentes, Manuel Atanasio. Guía histórico-descriptiva, administrativa, judicial y de domicilio de Lima. Librería central, 1861.

Gobineau, Arthur de. The Inequality of Human Races. Heinemann, 1915.

González Prada, Manuel. El tonel de Diógenes. Edición Tezontle, 1945.

Humboldt, Alexander. Ensayo Político sobre el reino de la Nueva España. Porrúa, 1966.

Inca Garcilaso de la Vega. Primera Parte de los Comentarios Reales de los Incas. Pedro Crasbeeck, 1609.

Lombroso, Cesare, y Guglielmo Ferrero. Criminal Woman, the Prostitute, and the Normal Woman. 1893. Duke UP, 2004.

Lombroso, Cesare. The man of genius. 1889. Walter Scott, 1896.

Matto de Turner, Clorinda. Aves sin nido. 1889. Biblioteca Ayacucho, 1994. 
Matto de Turner, Clorinda. Herencia. Imprenta Bacigalupi, 1893.

Matto de Turner, Clorinda. Índole. Imprenta Bacigalupi, 1891.

Matto de Turner, Clorinda. Leyendas y recortes. La Equitativa, 1893.

Matto de Turner, Clorinda. Tradiciones cuzqueñas completas. Biblioteca peruana, 1976.

Palma, Angélica. Vencida. Biblioteca Salvat, 1918.

Palma, Clemente. El porvenir de las razas en el Perú. Tesis. Universidad Nacional Mayor de San Marcos, 1897.

Palma, Edith, ed. Tradiciones peruanas completas. Aguilar, 1952.

Palma, Ricardo, y Manuel Ascencio Segura. El santo de Panchita. 1859. Carlos Prince, 1885 .

Palma, Ricardo. Cartas a Piérola sobre la ocupación chilena de Lima. Editorial Milla Batres, 1979.

Palma, Ricardo. Cien tradiciones peruanas. Ed. José Miguel Oviedo. Biblioteca Ayacucho, 1977.

Palma, Ricardo. Neologismos y americanismos. Imprenta y Librería de Carlos Prince, 1896.

Palma, Ricardo. Papeletas lexicográficas. 1903. Biblioteca Virtual Miguel de Cervantes, 2008.

Palma, Ricardo. Peruvian Traditions. Trad. Helen Lane. Oxford UP, 2004.

Palma, Ricardo. Refutación a un compendio de historia del Perú. Torres Aguirre, 1886.

Palma, Ricardo. Tradiciones en salsa verde y otros textos. Fundación Biblioteca Ayacucho, 2007.

Palma, Ricardo. Tradiciones. Biblioteca Virtual Universal, 2003. http://www.biblioteca.org.ar/libros/71164.pdf. Consultado 10 junio 2018.

Pardo y Aliaga, Felipe. Poesías y escritos en prosa. Imprenta de los caminos de hierro, 1869.

Renan, Ernest. Antichrist. 1873. Walter Scott, Ltd., 1900.

Renan, Ernest. La Reforme Intellectuelle et Morale. 1871. Michel Lévy Frères, 1875. 
Secundarias

Aguirre Beltrán, Gonzalo. La población negra de México1519-1810: Estudio Etnohistórico. Fondo de Cultura Económica, 1989.

Aguirre, Carlos. "Delito, raza y cultura. El desarrollo de la criminología en el Perú (18901930)". Diálogos en Historia, núm. 2, 2000, pp. 179-206.

Aguirre, Carlos. "Silencios y ecos: La historia y el legado de la abolición de la esclavitud en Haití y Perú". Centro de Desarrollo Étnico, 2004.

Aguirre, Carlos. Agentes de su propia libertad. Los esclavos de Lima y la desintegración de la esclavitud, 1821-1854. Pontificia Universidad Católica del Perú, 1993.

Alegre Henderson, Magally. Dissertation. Androginopolis: Dissident Masculinities and the Creation of Republican Peru (Lima, 1790-1850). Stony Brook U., 2012.

Anderson, Benedict. Imagined Communities. Reflections on the Origin and Spread of Nationalism. 1983. Verso, 2006.

Andresen, Julie Tetel, and Phillip M. Carter. Languages in the World: How History, Culture, and Politics Shape Language. Wiley Blackwell, 2016.

Annino, Antonio, y François-Xavier Guerra, coord. Inventando la nación. Iberoamérica. Siglo XIX. Fondo de Cultura Económica, 2003.

Arguedas, José María. Una recuperación indigenista del mundo peruano. Una perspectiva de la creación latinoamericana. Anthropos, 1992.

Armas Asin, Fernando. Liberales, protestantes y masones: modernidad y tolerancia religiosa. Perú siglo XIX. Fondo Editorial PUCP, 1998.

Asgharzadeh, Ailreza. Iran and the Challenge of Diversity: Islamic Fundamentalism, Aryanist Racism, and Democratic Struggles. Springer, 2007.

Augé, Marc. Los no lugares. Espacios del anonimato. Una antropología de la sobremodernidad. 1992. Gedisa, 2000.

Austin, Elisabeth L. "Reading Transgression in Ricardo Palma's Tradiciones en salsa verde". Revista hispánica moderna, vol. 67, núm. 2, 2014, pp. 127-42.

Back, Les y John Solomos, eds. Theories of Race and Racism. 2000. Routledge, 2001.

Balibar, Etienne, y lmmanuel Wallerstein. Race, Nation, Class. Ambiguous Identities. 1988. Verso, 1991. 
Barthes, Roland. Mythologies. 1957. The Noonday Press, 1991

Bazán Montenegro, Dora. Mujeres, ideas y estilo en las tradiciones de Palma. U Ricardo Palma, 2001.

Bennett, Andrew, and Nicholas Royle. An Introduction to Literature, Criticism and Theory. 1995. 4a ed. Routledge, 2009.

Bergner, Gwen S. Taboo Subjects. Race Sex and Psychoanalysis. Minnesota UP, 2005.

Best, Steven, y Douglas Kellner. Postmodern Theory. Critical Interrogations. 1991. Macmillan, 1994.

Bhabha, Homi K. The Location of Culture. Routledge, 1994.

Bhabha, Homi K., et al. "World Order". New perspectives quarterly, vol. 30, núm. 4, 2013, pp. 107-09.

Bonilla, Heraclio, ed. Indios, negros y mestizos en la independencia. Planeta, 2010.

Brekhus, Wayne. "A Sociology of the Unmarked. Redirecting Our Focus". Sociological Theory, vol. 16, núm. 1, 1998, pp. 34-51.

Bunoro, Aura Cristina. La recuperación del pasado incaico en las obras de Ricardo Palma, Corinda Matto de Turner y Manuel González Prada. Tesis. Árbol académico. U de Alicante, 2015.

Burkhardt, Richard W. The Spirit of System: Lamarck and Evolutionary Biology. Harvard UP, 1995.

Burns Glynn, William. El mundo de los amautas. Fondo Editorial U Alas Peruanas, 2007.

Camayd Freixas, Erik, ed. Orientalism and Identity in Latin America. Fashioning Self and Other from the Post-Colonial Margin. U of Arizona P. 2013.

Campbell, Margaret V. "The Tradiciones Cuzqueñas of Clorinda Matto de Turner". Hispania, vol. 42, núm. 4, 1959, pp. 492-97.

Canturías Acosta, Ricardo. Pancho Fierro. Editorial Brasa, 1995.

Capizzi, Joseph E. "The Children of God: natural slavery in the thought of Aquinas and Vitoria”. Theological Studies, núm. 63, 2002, pp. 31-52.

Carson, John. The Measure of Merit: Talents, Intelligence, and Inequality in the French and American Republics, 1750-1940. Princeton UP, 2007. 
Casalino Sen, Carlota. "De cómo los 'chinos' se transformaron y nos transformaron en peruanos. La experiencia de los inmigrantes y su inserción en la sociedad peruana, 1849-1930”. Investigaciones Sociales, vol. 9, núm. 15, 2005, pp. 109-32.

Castillo Sánchez, Wellington. Sartenazos que duelen o tiznan: tradiciones de Ricardo Palma de la región La Libertad. CEA, 2012.

Castles, Stephen. Ethnicity and Globalization. SAGE Publications, 2000.

Castro, Juan E. de. Mestizo Nations: Culture, Race, and Conformity in Latin American Literature. U of Arizona P, 2002.

Castro, Juan E. de. The spaces of Latin American literature: tradition, globalization, and cultural production. Palgrave Macmillan, 2008.

Chambilla Herrera, Luis. "Las Tradiciones en salsa verde como textos carnavalizados." Limite, núm. 5, 2005, pp. 49-57.

Chang-Rodríguez, Raquel. La apropiación del signo: tres cronistas indígenas del Perú. Arizona State U, 1988.

Chiri-Jaime, Alberto Sandro. El imaginario nacional en "Las tradiciones peruanas" de Ricardo Palma, ambientadas entre 1820 y 1885. Tesis. Temple U, 2012. Consultado 14 Ago. 2017.

Cohen, Anthony P. "Culture as Identity. An Anthropologist's View." New Literary History, núm. 24, 1993, pp. 195-209.

Cohen, William B. The French encounter with Africans: White response to Blacks, 15301880. Indiana UP, 2003.

Compton, Merlin D. "El sentimiento del honor en las Tradiciones peruanas de Ricardo Palma”. Revista de la Casa Museo Ricardo Palma, vol. 1, núm.. 1, 2000, pp. 3353.

Cornejo Polar, Antonio. La formación de la tradición literaria en el Perú. Centro de Estudios y Publicaciones, 1989.

Cornejo Polar, Antonio. Literatura y sociedad en el Perú: La novela indigenista. Lasontay, 1980.

Cornejo Polar, Antonio. Prólogo. "Aves sin nido como alegoría nacional". Clorinda Matto de Turner. Aves sin nido. 1889. Biblioteca Ayacucho, 1994, pp. 9-36. 
Cosamalón Aguilar, Jesús A. "Población y sociedad”. Perú. La construcción nacional. Tomo 2 (1830-1880). Ed. Carlos Contreras Carranza. Fundación Mapfre, 2014, pp. 221-82.

Coupland, Nikolas. Style Language Variation and Identity. Cambridge UP, 2007.

Cullis, James. "Climate, Providence and Agency in the Work of Henry Home, Lord Kames". www.sussex.academia.edu/JamesCullis. Consultado 7 Feb. 2018.

Dassow Walls, Laura. The Passage to Cosmos: Alexander von Humboldt and the Shaping of America. U of Chicago P, 2009.

Delacampagne, Christian. Racismo y Occidente. Argos Vergara, 1983.

Departamento Técnico de la Biblioteca Ayacucho. Cronología. Ricardo Palma. Cien tradiciones peruanas. Ed. José Miguel Oviedo. Biblioteca Ayacucho, 1977.

Derrida, Jacques. Writing and Difference. 1967. Routledge, 2005.

Diccionario Real Academia Española. www.rae.es. Consultado 10 Mayo 2018.

Doucet, Gastón Gabriel. "La encomienda Indiana". América y España: el encuentro de dos mundos. Eds. Edberto Oscar Acevedo, Ernesto J. A. Maeder, y Sonia Stengel. A. Estrada, 1988, pp. 40-52.

Edsall, Nicholas C. Toward Stonewall: Homosexuality and Society in the Modern Western World. U of Virginia P, 2003.

Enguix Grau, Begoña. "Sexualidad e identidades. Identidad homosexual”. Gazeta de Antropología, vol. 16, núm. 4, 2000. www.hdl.handle.net/10481/7498. Consultado 3 Jul. 2017.

Fanon, Frantz. Black Skin, White Masks. 1952. Pluto Press, 2008.

Fanon, Frantz. The Wretched of the Earth. 1961. Grove Press, 2004.

Fearon, James D. What is identity (as we now use the word)? Stanford U, 1999. Consultado 31 Ene. 2018.

Feliú Cruz, Guillermo. En torno de Ricardo Palma. Prensas de la U de Chile, 1933.

Fiengo-Varn, Aurora. 2003. "Reconciling the Divided Self. Inca Garcilaso de la Vega's Royal Commentaries and his Platonic View of the Conquest of Peru". Revista de Filología, Lingüística y Literatura, vol. 29, núm. 1, 2003, pp. 119-23.

Fisher, John Robert. Bourbon Peru 1750-1824. Liverpool UP, 2003. 
Floyd-Wilson, Mary. English Ethnicity and Race in Early Modern Drama. Cambridge UP, 2003.

Foucault, Michel. The History of Sexuality. Vol. 1. 1976. Pantheon Books, 1978.

Garcilaso de la Vega, Inca. Comentarios reales de los Incas. Ed. Aurelio Miró Quesada. Ediciones del Centenario del Banco de Crédito del Perú, 1985.

Gonzales, Osmar. "La correspondencia de Ricardo Palma". Contribuciones desde Coatepec, núm. 16, 2009, pp. 183-200.

Gootenberg, Paul. Población y etnicidad en el Perú republicano (siglo XIX). Instituto de estudios peruanos, 1995.

Greenberg, David F. The construction of homosexuality. U. of Chicago P., 1988.

Greenblatt, Stephen. Marvelous Possessions. The Wonder of the New World. 1991. The U of Chicago P, 1992.

Gruzinski, Serge. El pensamiento mestizo. Paidós, 2000.

Gunew, Sneja. "Postcolonialism and Multiculturalism: Between Race and Ethnicity". The Yearbook of English Studies, The Politics of Postcolonial Criticism, vol. 27, 1997, pp. 22-39.

Hampe Martínez, Teodoro. "Las Tradiciones peruanas y el imaginario de la nobleza titulada del virreinato”. Revista de Indias, vol. 61, núm. 222, 2001, pp. 331-44.

Harris, Marvin. The Rise of Anthropological Theory: A History of Theories of Culture. 1968. AltaMira Press, 2001.

Hempe Martínez, Teodoro. "Ricardo Palma, cronista de la Inquisición”. 2004. Biblioteca Virtual Miguel de Cervantes, 2009.

Hernández Fernández, Omaira. “Tiempo de indias: crónicas e imágenes del nuevo mundo y la expresión literaria latinoamericana”. Sapiens. Revista Universitaria de Investigación, vol. 9, núm. 1, 2008, pp. 213-35.

Hidalgo, Roxana. "La otredad en América Latina. Etnicidad, pobreza y feminidad". Polis, Revista de la Universidad Bolivariana, vol. 3, núm. 9, 2004.

Higgins, James. "Las Tradiciones peruanas de Ricardo Palma: la historia como legitimación”. Revista de la Casa Museo Ricardo Palma, vol. 2, núm. 2, 2001, pp. $15-28$. 
Hofstede, Geert. Culture's Consequences. Comparing Values, Behaviors, Institutions, and Organizations across Nations. 2nd ed. Sage, 2001.

Holguín Callo, Oswaldo. "Ricardo Palma y la cultura negra" Lo africano en la cultura criolla. Ed. Carlos Aguirre. Fondo Editorial del Congreso de la República, 2000, pp. 97-120.

Holguín Callo, Oswaldo. "Ricardo Palma y los bohemios. El grupo, cronología y guías". Boletín del Instituto Riva Agüero, núm. 20, 1993, pp. 139-54.

Holguín Callo, Oswaldo. Tiempo de infancia y bohemia. Ricardo Palma. Fondo Editorial de la Pontificia U Católica del Perú, 1994.

Holguín Delgado, Oswaldo. "Trazos para el perfil religioso de un liberal decimonónico (Ricardo Palma)". Revista de la Casa Museo Ricardo Palma, núm. 6, 2006, pp. 63-76.

Holquist, Michael. Dialogism. Bakhtin and his World. 1990. 2a ed. Routledge, 2002.

Hurtado Lazo, Alex. "Los Cuentos malévolos de Clemente Palma: pertinencia de su adscripción al género fantástico mediante un análisis del personaje Satán". Eds. César A. Coca Vargas, et al. Entre caníbales, núm. 4, 2017, pp. 83-90.

Juderías, Julián. La leyenda negra y la verdad histórica. Revista de Archivos, Bibliotecas y Museos, 1914.

Kapsoli Escudero, Wilfredo. "Miguel de Unamuno y Ricardo Palma. Una amistad epistolar". Revista de la Casa Museo Ricardo Palma, vol. 2, núm. 2, 2001, pp. 4367.

Klaiber S.J., Jeffrey L. "Los 'cholos' y los 'rotos': actitudes raciales durante la guerra del pacifico”. Histórica, vol. 11, núm. 1, 1978, pp. 27-37.

Kubler, George. The Indian Caste of Peru 1795-1940: A Population Study Based Upon Tax Records and Census Reports. U.S. Government Printing Office, 1952.

Labov, William. Principles of Linguistic Change: Social Factors. Blackwell Publishers, 2001.

Larson, Brooke, Olivia Harris, y Enrique Tandeter, eds. Ethnicity, Markets, and Migration in the Andes: At the Crossroads of History and Anthropology. Duke UP, 1995.

Lesevic, Bruno. La recuperación demográfica en el Perú durante el siglo XIX. Inandep, 1986. 
López-Beltrán, Carlos. "Sangre y temperamento: pureza y mestizajes en las sociedades de castas americanas". En Eds. Frida Gorbach, y Carlos López-Beltrán, Saberes locales: ensayos sobre historia de la ciencia en América Latina. El Colegio de Michoacán, 2008, pp. 289-342.

Lotman, Yuri. La Semiosfera II. Cátedra, 1998.

Lyle, John. "Some Issues in Postcolonial Theory". Brock University, 1998. www.brocku.ca/english/courses/4F70/postcol.php. Consultado 16 Abril 2016.

Mangan, Jane E. Transatlantic Obligations: Creating the Bonds of Family in ConquestEra Peru and Spain. Oxford UP, 2016.

Mangan, Jane E. Transatlantic Obligations: Creating the Bonds of Family in ConquestEra Peru and Spain. Oxford UP, 2016.

Mannarelli, María Emma. Limpias y Modernas. Género, higiene y cultura en la Lima del novecientos. Flora Tristán, 1999.

Mannarelli, María Emma. Pecados públicos: la ilegitimidad en Lima, XVII. 1993. Centro de la Mujer Peruana Flora Tristán, 2004.

Martínez Hoyo, Francisco. "La mirada del otro. Ricardo Palma y España". APORTES. Revista de Historia Contemporánea, vol. 23, núm. 83, 2013, pp. 105-21.

Martínez, Luz Ángela. "La espectacularización de la Colonia y fundación de la identidad republicana en las Tradiciones Peruanas de Ricardo Palma". Revista chilena de literatura, núm. 63, 2003. www.revistaliteratura.uchile.cl/index.php/RCL/article/view/1636. Consultado 18 Abril 2018.

Martos Carrera, Marco. "Anales de la Inquisición de Lima: Ricardo Palma, La vela verde y el sambenito". Escritura y pensamiento, año 1, n 2, 1998, pp. 213-35.

Mazzotti, José Antonio. Introducción. "Las agencies criollas y la ambigüedad colonial de las letras hispanoamericanas". Agencias criollas. La ambigüedad colonial en las letras hispanoamericanas. Ed. José Antonio Mazzotti. Instituto Internacional de Literatura Iberoamericana, 2000, pp. 8-35.

Méndez G., Cecilia. "De indio a serrano: nociones de raza y geografía en el Perú (siglos XVIII-XXI)”. Histórica, vol. 35, núm. 1, 2011, pp. 53-102.

Méndez G., Cecilia. "Incas Sí, Indios No: Notes on Peruvian Creole Nationalism and Its Contemporary Crisis". Journal of Latin American Studies, vol. 28, núm. 1, 1996, pp. 197-225. 
Merriam-Webster Dictionary. www.merriam-webster.com. Consultado 10 Feb. 2018.

Milanich, Jerald T. "Un nuevo mundo: indígenas y europeos en La Florida del siglo XVI". Franqueando fronteras. Garcilaso de la Vega y La Florida del Inca. Ed. Raquel Chang-Rodríguez. Pontificia Universidad Católica del Perú, 2006.

Miles, Robert, y Malcolm Brown. Racism. 1989. 2a ed. Routledge, 2003.

Miró, César. Don Ricardo Palma: el patriarca de las Tradiciones. Losada, 1953.

Moreira, Rubén Alejandro. "Raza y dominación en las fundaciones nacionales de Palma, Tapia y Galván”. Actas de Tapia, 2004, pp. 87-104.

Moyar, Dean, ed. The Routledge Companion to Nineteenth Century Philosophy. Routledge, 2010.

Muñoz, Fanni. Diversiones públicas en Lima 1890-1920: la experiencia de la modernidad. Red para el Desarrollo de las Ciencias Sociales en el Perú, 2001.

Novoa, Adriana. "Darwinism in Spanish America". Darwin in Atlantic Cultures: evolutionary visions of race, gender, and sexuality. Eds. Janette Eileen Jones y Patrick B. Sharp. Routledge, 2010. Pp. 237-59.

O'Gorman, Edmundo. La invención de América. Fondo de cultura económica, 1995.

Oliart, Patricia. "Poniendo a cada quien en su lugar. Estereotipos raciales y sexuales en la Lima del siglo XIX". Mundos Interiores: Lima, 1850-1950. Eds. Aldo Panfichi y Felipe Portocarrero. U del Pacífico, 1998, pp. 261-89.

O'Phelan Godoy, Scarlett. "Una rebelión abortada. Lima 1750: La conspiración de los indios olleros de Huarochirí". Varia Historia, Belo Horizonte, núm. 24, 2001, pp. $7-32$.

Otis, Laura, ed. Literature and Science in the Nineteenth Century. An Anthology. Oxford UP, 2002.

Oviedo, José Miguel. Genio y figura de Ricardo Palma. Editorial Universitaria de Buenos Aires, 1965.

Oviedo, José Miguel. Historia de la literatura hispanoamericana. Del romanticismo al modernismo. 1997. Alianza, 2007.

Oviedo, José Miguel. Prólogo. Ricardo Palma. Cien tradiciones peruanas. Ed. José Miguel Oviedo. Caracas, Venezuela: Biblioteca Ayacucho, 1977. 
Pamo Reyna, Oscar G. "El travestismo en Lima: de la Colonia a la República". Acta Herediana, vol. 56, 2015, pp. 26-38.

Paso, Fernando del. News from the Empire. Dalkey Archive Press, 2009.

Pastor, Beatriz. Discurso narrativo de la conquista de América: mitificación y emergencia. Casa de las Américas, 1983.

Pastor, Carlos. El control sanitario del matrimonio. U Nacional Mayor de San Marcos, 1924.

Peloso, Vincent, y José Ragas. "Estadística y sociedad en el Perú poscolonial: el desconocido censo de Lima de 1860”. Histórica, vol. 25, núm. 2, 2001, pp. 275 93.

Peluffo, Ana. Lágrimas andinas: Sentimentalismo, género y virtud republicana en Clorinda Matto de Turner. Instituto Intencional de Literatura Iberoamericana, 2005.

Poddar, Prem, Rajeev S. Patke, y Lars Jensen, eds. A Historical Companion to Postcolonial Literatures. Continental Europe and its Empires. Edinburgh UP, 2008.

Popik, Kristin M. "The Philosophy of Woman of St. Thomas Aquinas". www.media.christendom.edu/wp-content/uploads/2017/05/Kristin-M-Popik-ThePhilosophy-of-Woman-of-St-Thomas-Aquinas.pdf. Consultado 10 Apr. 2018.

Porras Barrenechea, Raúl: Tres ensayos sobre Ricardo Palma. Librería Juan Mejía Baca, Tipografía Peruana, 1954.

Portocarrero Maisch, Gonzalo. La urgencia por decir nosotros: Los intelectuales y la idea de nación en el Perú republicano. Fondo Editorial de la Pontificia Universidad Católica del Perú, 2015. Documento digital.

Pratt, Mary Louise. "Las mujeres y el imaginario nacional en el siglo XIX". Revista de Crítica Literaria Latinoamericana, vol. 19, núm. 38, 1993, pp. 51-62.

Priest, Stephen, ed. Jean-Paul Sartre. “Others”. Jean-Paul Sartre: Basic Writings. Routledge, 2001.

Quiroz Ávila, Rubén. "Hermenéutica de El porvenir de las razas en el Perú". Solar, vol. 4, núm. 4, 2008, pp. 139-56.

Revelle, William. "Francis Galton". The Encyclopedia of Clinical Psychology. Eds. R. Cautin, R. y S. Lilienfeld. Wiley-Blackwell, 2014. 
Richards, Robert J. "The Linguistic Creation of Man: Charles Darwin, August Schleicher, Ernst Haeckel, and the Missing Link in Nineteenth-Century Evolutionary Theory". Experimenting in Tongues: Studies in Science and Language. Ed. Matthias Doerres. Stanford UP, 2002, pp. 21-48.

Rochabrún, Guillermo. “Una vana pretensión: ser racista en el Perú”. Guillermo Rochabrún, Paulo Drinot, y Nelson Manrique. Racismo, ¿solo un juego de palabras? Debate a partir del conversatorio: "Racismo y desigualdad en la historia del Perú”, del Ministerio de Cultura. Serie diversidad cultural, núm. 1, 2014. www.red.pucp.edu.pe/ridei/files/2014/09/160914.pdf. Consultado 15 Mayo 2018.

Rodríguez Pastor, Humberto. "La calle del Capón, el Callejón Otaiza y el Barrio Chino". Eds. Aldo Panfichi y Felipe Portocarrero. Mundos interiores. Lima 1850-1950. U. del Pacífico, pp. 397-430.

Rodríguez Pastor, Humberto. Hijos del celeste imperio en el Perú (1850-1900). Migración, agricultura, mentalidad y explotación. Instituto de Apoyo Agrario, 1989.

Rodríguez-Arenas, Flor María. "El lenguaje coloquial y el humor en las Tradiciones en salsa verde de Ricardo Palma". Revista de la Casa Museo Ricardo Palma, vol. 2, núm. 2, 2001, pp. 69-90.

Romero de Tejada y Picatoste, Pilar. Los cuadros de mestizaje del virrey Amat. La representación etnográfica en el Perú colonial. Museo de Arte de Lima, 2000.

Romero de Tejada y Picatoste, Pilar. Museo Nacional de Antropología de Madrid. CER.es. Red Digital de Colecciones de Museos de España. Ministerio de Educación, Cultura y Deporte, España. www.ceres.mcu.es. Consultado 23 Marzo 2018

Romero Meza, Eddy. "Breve historia del racismo en el Perú". Julio 2014. Consultado 14 Mar. 2018.

Rostworowski, María, Javier Mariátegui, Carlos Aguirre, et al., eds. Lo africano en la cultura criolla. Fondo Editorial del Congreso del Perú, 2000.

Said, Edward W. Orientalism. 1978. Penguin Books, 2003.

Salinas Aguilar, Luzmila Cecilia. Afinidades y diferencias de dos periodistas literarios del siglo XIX. Mariano José de Larra y Ricardo Palma. Tesis. U. Complutense de Madrid, 2009.

Sampson Vera Tudela, Elisa. Ricardo Palma's Tradiciones. Illuminating Gender and Nation. Bucknell UP, 2012. 
Sarco, Álvaro. "Irresueltos discursos del canon cultural peruano". Escritura y Pensamiento, vol. 8, núm. 16, 2005, pp. 181-93.

Selden, Raman, Peter Widdowson, y Peter Brooker. A reader's guide to contemporary literary theory. 5a ed. Pearson Longman, 2005.

Sievers Thomas, Ruth. "Las Fuentes de las Tradiciones”. Revista Iberoamericana, 1949, pp. 461-69.

Silverman, Gail. "Los Tocapus Incas como escritura pictórica. Lectura de un vaso ceremonial Inca". Sublevando el virreinato: documentos contestatarios a la historiografía tradicional del Perú colonial. Eds. Laura Laurencich Minelli, y Paulina Numhauser. Abya-Yala, 2007, pp. 443-67.

Simpson, Donald. "Phrenology and the neurosciences: contributions of F. J. Gall and J. G. Spurzheim”. Australia and New Zealand Journal of Surgery, vol. 75, núm. 6, 2005, pp. 475-82.

Smith, Nicholas D. "Plato and Aristotle on the Nature of Women". Journal of the History of Philosophy, vol. 21, núm. 4, 1983, pp. 467-78.

Spencer-Oatey, Helen. What is culture? A compilation of quotations. GlobalPAD Core Concepts, 2012.

Spivak, Gayatri Chakravorty. ¿Puede hablar el subalterno? Revista Colombiana de Antropología, vol. 39, 2003, pp. 297-364.

Spivak, Gayatri Chakravorty. "Can the Subaltern Speak?” Critique of Postcolonial Reason, 2010, pp. 21-78.

Stafford, Tom. "Is race perception automatic?”. BBC Future, 23 Apr. 2013, http://www.bbc.com/future/story/20130423-is-race-perception-automatic. Consultado 31 Ene. 2018.

Starn, Orin, Carlos Iván Degregori, and Robin Kirk, eds. The Peru reader: history, culture, politics. Duke UP, 1995.

Stewart, Watt. Chinese Bondage in Perú: A history of the Chinese Coolie in Perú 18491874. Duke UP, 1951.

Sulén, Félix. Tesis. La inmigración china en el Perú: 1849-1874. Principales características de la mano de obra china en las haciendas de la costa norte del Perú. Pontificia U Católica del Perú, 1989.

Tauzin Castellanos, Isabelle. "Refranes y tradiciones en la obra de Ricardo Palma". Biblioteca Virtual Miguel de Cervantes, 2008. 
Tauzin-Castellanos, Isabelle. "Ricardo Palma o la estética del detalle". HAL Archive Ouverte, 2009, pp. 1-10.

Thorp, Rosemary, y Maritza Paredes. Ethnicity and the Persistence of Inequality: The Case of Peru. Palgrave Macmillan, 2010.

Todorov, Tzvetan. La Conquista de América. El problema del otro. 1982. 5a ed. Siglo Veintiuno Editores, 1994.

Todorov, Tzvetan. The Fear of Barbarians. U of Chicago P, 2010.

Torre, Mariela de la. "Las ideas lingüísticas de Ricardo Palma en sus dos obras lexicográficas: Neologismos y americanismos y Papeletas lexicográficas". Boletín hispánico helvético, 23, 2014, pp. 165-93.

Trudgill, Peter. The Social Differentiation of English in Norwich. Cambridge UP, 1974.

Twinam, Ann. Purchasing Whiteness. Pardos, Mulattos, and the Quest for Social Mobility in the Spanish Indies. Stanford UP, 2015. Digital File.

Tyson, Lois. Critical Theory Today. A User-Friendly Guide. 2a ed. Routledge, 2006.

Tyutina, Svetlana. "Cantar de Mio Cid. Creation of the Founding Paradigm of Hispanic Orientalism." Peripheral Transmodernities: South-to-South intercultural dialogues between the Hispanic World and "the Orient." Cambridge Scholar Publishing, 2012, pp. 178-96.

Umphrey, George W., y Carlos García-Prada. Introducción. Ricardo Palma. Flor de tradiciones. Editorial Cultura, 1943.

Universidad Ricardo Palma. "Tradiciones Peruanas de Ricardo Palma 'La saya y el manto"”. www.urp.edu.pe/relacionesuniversitarias/tradiciones-peruanas.html. Consultado 27 Dic. 2017.

Urdapilleta-Muñoz, Marco. "El ethos de Ricardo Palma en sus tradiciones". La Colmena, núm. 81, 2014, pp. 45-50.

Valero Juan, Eva María. "Evocaciones de la Arcadia colonial en la literatura peruana. de Ricardo Palma a Julio Ramón Ribeyro". Biblioteca Virtual Miguel de Cervantes, 2005, pp. 230-37.

Valero Juan, Eva María. "Trayectorias literarias para la construcción de la Lima mestiza”. Hipertexto, núm. 5, 2007, pp. 20-34.

Valero Juan, Eva María. Lima en la Tradición Literaria Del Perú: De la Leyenda Urbana a la Disolución. U Lleida, 2003. 
Van Pelt, Tamise. "Otherness". The Johns Hopkins UP, 2000. www.pmc.iath.virginia.edu/text-only/issue.100/10.2vanpelt.txt. Consultado 16 Abril 2016.

Vargas Yábar, Miguel. Las empresas del pensamiento. Clorinda Matto de Turner (18521909). Biblioteca Quillqakuna, 2013.

Velázquez Castro, Marcel. “La cultura”. Perú. La construcción nacional. Tomo 2 (18301880). Ed. Carlos Contreras Carranza. Fundación Mapfre, 2014, pp. 283-342.

Velázquez Castro, Marcel. "La narrativa breve de Clorinda Matto: de la tradición y leyenda románticas al cuento modernista". Escritura y Pensamiento, vol. XV, núm. 31, 2012, pp. 75-103.

Velázquez Castro, Marcel. El revés del marfil. Nacionalidad, etnicidad, modernidady género en la literatura peruana. U Nacional Federico Villarreal, 2002.

Velázquez Castro, Marcel. La mirada de los gallinazos. Cuerpo, fiesta y mercancía en el imaginario sobre Lima (1640-1895). Fondo Editorial del Congreso del Perú, 2013.

Velázquez Castro, Marcel. Las máscaras de la representación. El sujeto esclavista y las rutas del racismo en el Perú (1775-1895). U Nacional Mayor de San Marcos, 2005.

Villanes Cairo, Carlos, ed. Introducción. Tradiciones peruanas (selección). Cátedra, 1994.

Villari, Cristina, y Leonel A. Menacho López. "La situación lingüística actual en Ancash como reflejo de la historia de la política lingüística del Perú". Indiana, vol. 34, núm. 1, 2017, pp. 129-147.

Walter D. Mignolo. Afterword. "What Does the Black Legend Have to Do with Race?". Rereading the Black Legend: The Discourses of Religious and Racial Difference in the Renaissances Empires. Eds. Margaret Greer, Walter Mignolo, y Maureen Quilligan. U of Chicago P, 2007, pp. 188-201.

Ward, Julie K. "The Roots of Modern Racism: Early Modern Philosophers On Race". The Critique, 2016. www.researchgate.net/publication/317623852_The_Roots_of_Modern_RacismEa rly_Modern_Philosophers_on_Race.Consultado 8 Feb. 2018.

Watson, Maida. "Arte y literatura en el costumbrismo peruano decimonónico". Revista de la Casa Museo Ricardo Palma, núm. 6, 2006, pp. 40-61. 
Watson, Maida. "La presencia china en la literatura peruana del siglo XIX". Extremo Occidente y Extremo Oriente. Herencias asiáticas en la América hispánica. Eds. Axel Gasquet, y Georges Lomné. IFEA, 2016.

Weedon, Chris. Identity and Culture: Narratives of Difference and Belonging. Open UP, 2004.

White, Hayden. Tropics of Discourse. Essays in Cultural Criticism. Johns Hopkins UP, 1978.

Wuffarden, Luis Eduardo. Ilustración versus tradiciones locales, 1750-1825. Pintura en Hispanoamérica 1550-1820. Ediciones El Viso, 2014.

Young, Robert J. C. Colonial Desire: Hybridity in Theory, Culture and Race. Routledge, 2005. 
VITA

\title{
PRIMAVERA CUDER
}

\author{
Born, Udine, Italy
}

2014-2017

M.A., Spanish

Florida International University

Miami, Florida

2010-2014

$\mathrm{PhD}$, English

University of Jaen

Jaen, Spain

2098-2009

M.A., English

University of Jaen

Jaen, Spain

$2003-2008$

B.A. English

University of Granada

Granada, Spain

\section{PUBLICATIONS AND PRESENTATIONS}

Cuder, P. "Mestizo educado, diablo encarnado": Identidades silenciadas y diversidad étnica en Ricardo Palma." (Work in progress).

Cuder, P. "Learning Spanish in Miami: A survey about Spanish and Spanish speakers in Miami." (Work in progress).

Cuder, P. "Determinismo, nación e imperialismo en la Generación del 98: Idearium español de Ángel Ganivet y Defensa de la hispanidad de Ramiro de Maeztu." El Cid, 2018.

Cuder, P., et al. A TBLT curriculum for Online Courses of Spanish for Business purpose. (Work in progress).

Cuder, P., and Jesús López-Peláez, eds. A bilingual edition of Lust's Dominion. Peter Lang, 2018. (Accepted for publication)

Cuder, P. Spaniards, moor and women in early modern English discourses. Jaen UP, March 2016. 
Cuder, P. “'Spaniard or Moor, the saucy slave shall die.' Early Modern English Attitudes towards the Stranger in Thomas Dekker's Lust's Dominion." Heidelberg U. June 2013.

Cuder, P., and Yolanda Caballero, eds. The Construction of the Other in Early Modern Britain: Attraction, Rejection, Symbiosis. Heidelberg U. June 2013.

Iv International Symposium On Languages For Specific

Feb.2224,2018

Purposes (Islsp)/Ciber Business Language Conference

Cuder, P. "Learning Spanish in Miami: A survey about Spanish and Spanish speakers at Florida International University" U. of Florida, Gainesville, FL

SAMLA 89 International Conference, Atlanta, GA

Nov. 3-

5, 2017

South Atlantic Modern Language Association

Cuder, P. "Identidades silenciadas y auto-impuestas: mulatos y mestizos en las

Tradiciones de Ricardo Palma"

University of Florida, Gainesville, FL

Jan. 21, 2017

Interdisciplinary Graduate Colloquium on Hispanic Ling., Lit. and Cult. Cuder, P., Claudia Battistel, Anna Cepeda, and Jeniffer Fernandez.

“Task-Based Syllabus for Spanish for Business Purposes.” Interdisciplinary Graduate Colloquium on Hispanic Linguistics, Literature and Culture

SAMLA 88 International Conference, Jacksonville, FL

Nov. 4-

6, 2016

South Atlantic Modern Language Association

Cuder, P. "Mujeres y diversidad étnica en Cien tradiciones de Ricardo Palma"

Florida International University

2016

International Conference. XII Encuentro Internacional de Mujeres Escritoras

Cuder, P. “Identidad y 'raza' en Latinoamérica. Representación de la negritud y la mujer puertorriqueña en Sirena de Francisco Arriví"

University of Florida, Gainesville, FL

Feb. 20,

2016

Interdisciplinary Graduate Colloquium on Hispanic Ling., Lit. and Cult.

Cuder, P. "“No son más que caníbales.' Rechazo y fascinación hacia lo ajeno en Cinco horas con Mario (1966) de Miguel Delibes."

Florida International University 2015

Nov. 20,

International Conference $19^{\text {th }}$ c. Latin American \& Spanish Literature 
Cuder, P. "Representación de la diversidad y la otredad en Cien tradiciones peruanas (1864-1910) de Ricardo Palma."

Florida International University

April

2015

International Conference Literature and Crisis

Cuder, P. '’Racial,' Religious and Political Enemies within Spain:

Changing Representations of the Other" 